$$
\text { UNIVERSIDADE DE SÃO PAULO }
$$

FACULDADE DE FILOSOFIA, LETRAS E CIÊNCIAS HUMANAS DEPARTAMENTO DE LETRAS MODERNAS

PROGRAMA DE PÓS-GRADUAÇÃo EM LÍNGUA E LITERATURA ALEMÃ

\author{
RENATO OLIVEIRA DE FARIA
}

\title{
“ASSALTO CONTRA O LIMITE": \\ FORMA DANIFICADA E HISTÓRIA EM FRANZ KAFKA
}

Versão Corrigida

São Paulo

2011 
UNIVERSIDADE DE SÃO PAULO

FACULDADE DE FILOSOFIA, LETRAS E CIÊNCIAS HUMANAS

DEPARTAMENTO DE LETRAS MODERNAS

PROGRAMA DE PÓS-GRADUAÇÃO EM LÍNGUA E LITERATURA ALEMÃ

RENATO OLIVEIRA DA FARIA

\title{
“ASSALTO CONTRA 0 LIMITE”: \\ FORMA DANIFICADA E HISTÓRIA EM FRANZ KAFKA \\ Versão Corrigida
}

\begin{abstract}
Tese apresentada ao Programa de Pós-Graduação em Língua e Literatura Alemã, do Departamento de Letras Modernas da Faculdade de Filosofia, Letras e Ciências Humanas da Universidade de São Paulo, para a obtenção do título de Doutor em Letras.
\end{abstract}

Orientador: Prof. Dr. Stefan Wilhelm Bolle

São Paulo

2011 
Die Grenze, die meine Denkfähigkeit mir setzt, sind ja eng genug, das Gebiet aber, das hier zu durchlaufen wäre, ist das Endlose.

(Franz Kafka, Beim Bau der Chinesischen Mauer)

Os limites que minha capacidade de pensar me impõe já são estreitos o bastante, mas a região que aqui teria de ser percorrida é o infinito.

(Franz Kafka, Durante a construção da Muralha da China) 
À Cecília,

que me ensinou a neutralizar o feitiço do monstro da palha;

À Marília,

sem a qual este trabalho, ainda que danificado, sequer existiria. 


\section{AGRADECIMENTOS}

Ao meu orientador Willi Bolle, pela dedicada discussão de minha pesquisa e pelo incentivo constante.

Ao professor Peter-André Alt, por ter me acolhido como bolsista DAAD/CNPq na Universidade Livre de Berlim.

Ao professor Burkhardt Wolf, por ter me recebido em seu seminário sobre os "escritos de repartição" de Kafka na Universidade Humboldt de Berlim.

À FAPESP (Fundação de Amparo à Pesquisa do Estado de São Paulo), pelo apoio financeiro que viabilizou esta pesquisa.

Ao DAAD (Serviço Alemão de Intercâmbio Acadêmico) e ao CNPq (Conselho Nacional de Desenvolvimento Científico e Tecnológico), pelos recursos que tornaram possível uma estadia de pesquisa na Universidade Livre de Berlim, sob a orientação do professor PeterAndré Alt. 


\section{RESUMO}

Esta tese busca refletir sobre a configuração fragmentária da produção do escritor Franz Kafka (1883-1924). Procura-se mostrar como a partir do final de 1916 ocorre na produção kafkiana uma inflexão formal decorrente de uma mudança no modo do escritor conceber o caráter "danificado" de sua escrita.

Palavras-chave: Franz Kafka; forma danificada; literatura e história; Monarquia do Danúbio (Império Habsburgo); Primeira Guerra Mundial.

\section{ABSTRACT}

This thesis reflects upon the fragmentary configuration of Franz Kafka's production. It aims to show how, from the end of 1916, occurs an formal inflection in the Kafkaesque production due to a change in the way the writer conceives the "damaged" character of his writing.

Key words: Franz Kafka; damaged form; literature and history; Danubian Monarchy (Habsburg Empire); First World War. 


\section{SUMÁRIO}

Abreviaturas

8

Introdução 9

Capítulo 1: A reviravolta formal de 1916/1917 17

- Ulcus tangere. 27

- A perversão do limiar. 34

- A radicalização da deformação ou o mundo como emaranhado in-finito 40

- Entre a semi-destruição e o semi-acabamento 64

Capítulo 2: A velha Monarquia do Danúbio desce aos infernos 71

- Parte 1: Estudo sobre o fragmento de drama 0 quarda da tumba. 78

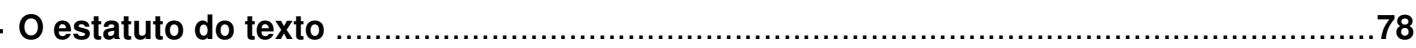

. Em defesa de $\underline{O}$ guarda da tumba contra os seus não-admiradores.............................87

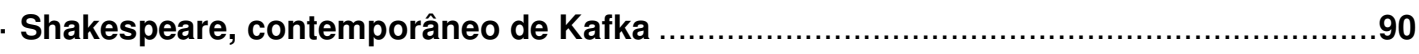

- Parte 2: O ponto de vista da decomposição ...................................................105

Capítulo 3: Reflexões sobre a "China Européia” .................................... 117

Considerações finais ......................................................................... 128

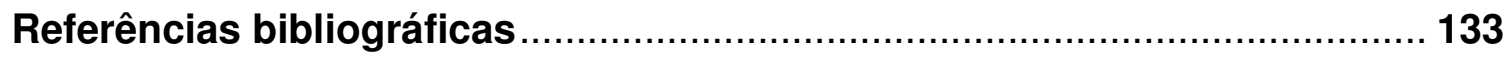




\section{ABREVIATURAS}

KAFKA, Franz. Kritische Kafka Ausgabe: Schriften/Tagebücher/Briefe. Org. por Jürgen Born, Gerhard Neumann, Malcolm Pasley e Jost Schillemeit. Frankfurt am Main: Fischer, 1982ff:

- KKA N1 = Nachgelassene Schriften und Fragmente I. Org. por Malcom Pasley. 1993.

- KKA N2 = Nachgelassene Schriften und Fragmente II. Org. por Jost Schillemeit. 1992.

- KKA T = Tagebücher. Org. por Hans-Gerd Koch, Michael Müller e Malcom Pasley. 1990.

- KKA S = Das Schloß. Org. por Malcom Pasley. 1982.

- KKA V = Der Verschollene. Org. por Jost Schillemeit. 1983.

- KKA $\boldsymbol{P}=$ Der Proceß. Org. por Malcom Pasley. 1990.

- KKA D = Drucke zu Lebzeiten. Org. por Wolf Kittler, Hans-Gerd Koch e Gerhard Neumann. 1994.

- KKA AS = Amtliche Schriften. Org. por Klaus Hermsdorf e Benno Wagner. 2004.

KAFKA, Franz. Historisch-Kritische Kafka Ausgabe sämtlicher Handschriften, Drucke und Typoskripte. Org. por Roland Reuß und Peter Staengle. Frankfurt am Main: Stroemfeld, 1997ff:

- HKKA 01/2 = Oxforder Oktavhefte 1 \& 2. Org. por Roland Reuß. 2006.

- HKKA 03/4 = Oxforder Oktavhefte 3 \& 4. Org. por Roland Reuß und Peter Staengle. 2008.

- HKKA 05/6 = Oxforder Oktavhefte 5 \& 6. Org. por Roland Reuß und Peter Staengle. 2009.

- HKKA 07/8 = Oxforder Oktavhefte 7 \& 8. Org. por Roland Reuß und Peter Staengle. 2010.

- $\boldsymbol{L A}=$ KAFKA, Franz. Ein Landarzt. (Fac-símile da 1ª Edição. Leipzig: Kurt Wolff Verlag, 1920). Frankfurt am Main: Stroemfeld, 2006.

- $\boldsymbol{M R}=$ KAFKA, Franz. Um médico rural. Tradução e posfácio de Modesto Carone. São Paulo: Companhia das Letras, 1999.

- $\boldsymbol{A F / C}=$ KAFKA, Franz. Um artista da fome/A construção. Tradução e posfácio de Modesto Carone. São Paulo: Companhia das Letras, 1999.

- NE = KAFKA, Franz. Narrativas do espólio. Tradução e posfácio de Modesto Carone. São Paulo: Companhia das Letras, 2002. 


\section{INTRODUÇÃO}

Was ich berühre, zerfällt

(Franz Kafka, "Oktavheft E”, 1917)

É muito difícil se manter indiferente ao fato de que a produção literária do escritor Franz Kafka (1883-1924) constitui, com efeito, um conjunto assombroso e quase infindável de fragmentos, abrangendo desde romances inconclusos até "pequenas narrativas" inacabadas. Tendo-se em conta tal dado, não surpreende então que Kafka nunca tenha se referido à sua própria produção como "obra" ("Werk") mas comumente como "escrita" ("Schrift") ou ainda, e não sem pouca ironia, como "rabiscos" ("Gekritzel"). O presente trabalho propõe-se a fazer um estudo sobre esta configuração fragmentária, buscando evidenciar e explorar suas implicações históricas. Assinale-se, à margem, que esta referência ao âmbito histórico dentro do qual os escritos kafkianos foram engendrados não deverá levar "para fora da obra de arte, mas sim levar mais fundo para dentro dela"2:

Das geschichtliche Moment ist den Kunstwerken konstitutiv; die authentischen sind die, welche dem geschichtlichen Stoffgehalt ihrer Zeit vorbehaltlos und ohne die Anmaßung über ihr zu sein sich überantworten. Sie sind die ihrer selbst unbewußte Geschichtsschreibung ihrer Epoche [...]. ${ }^{3}$

Contudo, embora a configuração fragmentária perpasse de ponta a ponta todo o conjunto da produção literária de Kafka (não se restringindo assim a um determinado ciclo produtivo nem tampouco a um gênero ou sub-gênero literário em particular), há com relação a este aspecto uma inflexão no modo como o escritor, a partir do final de 1916,

\footnotetext{
${ }^{1}$ F. Kafka, "Oktavheft E", em KKA N1, p. 407 (esta pequena anotação foi transcrita exatamente da forma como aparece no manuscrito kafkiano, ou seja, sem pontuação final): "O que eu toco, desmorona-se". Salvo indicação em contrário, todas as traduções contidas neste trabalho são minhas.

${ }^{2}$ T. W. Adorno, "Palestra sobre lírica e sociedade", em Notas de literatura I, p. 66.

${ }^{3}$ T. W. Adorno, Ästhetische Theorie, p. 272: "O momento histórico é constitutivo nas obras de arte; as autênticas são aquelas que se entregam sem reservas ao teor da matéria histórica de seu tempo e sem a pretensão sobre ele. Elas são a historiografia inconsciente de si mesma de sua época [...]."
} 
passa a conceber este caráter "danificado"” de sua escrita, a saber, o caráter desde sempre fragmentário de sua produção passa a ser radicalmente assumido e internalizado por sua própria forma. É como se a forma kafkiana tomasse então consciência da impossibilidade de seu acabamento (uma consciência, ressalte-se, agora imanente à própria configuração literária).

Pelo fato, portanto, de marcar uma reorientação radical da escrita de Kafka, este trabalho concentrar-se-á sobretudo nesta produção que se inicia no final de 1916 e se estende de forma um pouco irregular até maio de 1918; sendo que do conjunto destes escritos dois fragmentos em particular serão objeto de uma análise mais detida: o fragmento de drama $\underline{O \text { guarda da tumba }}{ }^{5}$ escrito em novembro/dezembro de 1916 e a narrativa fragmentária Durante a construção da muralha da China escrita em março de 1917.

\footnotetext{
${ }^{4}$ O qualificativo "danificado" ("beschädigt"), aplicado ao domínio da escrita, aparece sintomaticamente em um pequeno fragmento, datado do final de março de 1917; neste fragmento Kafka explora a poderosa imagem de "algumas páginas" que estariam "danificadas":
}

Hier folgen noch einige Seiten, die aber allzu beschädigt sind, als daß innen etwas bestimmtes entnommen werden könnte. (F. Kafka, "Oktavheft C", em KKA N1, p. 361, grifos meus)

Aqui seguem-se ainda algumas páginas, que porém estão demasiadamente danificadas, de modo que nada definido poderia ser extraído delas.

Retornaremos a este pequeno fragmento no primeiro capítulo e também nas considerações finais deste trabalho; desde já no entanto apropriamo-nos do qualificativo "danificado", voltando-o para a própria forma elaborada por Kafka.

${ }^{5}$ Utilizaremos neste trabalho o seguinte padrão para a referência à produção de Kafka: sempre que os títulos dos textos citados não tiverem sido concebidos pelo próprio escritor, mas forem invenção de Max Brod, o primeiro editor de Kafka, eles estarão aqui sublinhados. Esta distinção pretende, na medida do possível, ressaltar o caráter "não-acabado", ou melhor, "danificado" da maior parte dos textos deste autor (assinalando assim o fato de que a maioria deles sequer havia recebido um título por parte do escritor). Por outro lado, e levando-se em conta que não foram poucas as análises que tomaram, inadvertidamente, os títulos inventados pelo amigo de Kafka como referência importante ou até mesmo como ponto de partida para o trabalho de interpretação (para se ter uma idéia, entre as "vítimas" de Brod contam-se críticos sofisticados como Günther Anders e Walter Benjamin), este procedimento busca também chamar a atenção dos leitores e críticos kafkianos para este tipo de equívoco. Infelizmente, leitores e críticos deste escritor ficaram, durante quase meio século, reféns das problemáticas edições de Max Brod que, como se sabe, inventou um "Kafka que escreve textos coerentes e esteticamente acabados. As categorias de 'versão', 'texto definitivo' e 'fragmento' que orientam o procedimento editorial de Brod definem-se tendo por pano de fundo um conceito clássico de texto e obra [...]." (A. Schütterle, Franz Kafkas Oktavhefte, p. 269.) Porém, os limites de uma produção como a de Kafka não coincidem, de modo algum, com aqueles do acabamento; por isso mesmo a sobreposição de critérios e categorias tradicionais a ela mostrar-se-á, no mínimo, problemática. Apenas com a chamada Edição Crítica, publicada a partir do início dos anos 1980, passou-se finalmente a dispor de um texto muito mais confiável. Porém, várias opções dos organizadores desta edição - particularmente a de remeter variantes e trechos riscados no manuscrito kafkiano a volumes suplementares que continham todo o aparato crítico-editorial - pareceram a muitos críticos suspeitas na medida em que implicava também uma intervenção no texto original, portanto, uma interpretação. Nesse sentido, a alardeada pretensão - qual seja, a da "produção de um texto autêntico" - exposta desde o princípio pelos seus editores não teria se concretizado por inteiro. Precisamente para se reparar este problema, em meados dos anos 1990, foi iniciada a publicação da chamada Edição Histórico-Crítica que com a reprodução fotográfica dos manuscritos, acompanhada por uma "transcrição diplomática", renuncia a qualquer intervenção editorial, deixando todo trabalho interpretativo a cargo dos críticos. 
Contudo, para que a referida mudança no modo do escritor conceber o caráter danificado de sua escrita possa ser melhor apreendida, faz-se necessário um esboço, mesmo que em grandes linhas, da evolução literária do chamado "Kafka maduro". Como se sabe, há entre os críticos kafkianos um raro consenso em relação à sua produção: a escrita de $O$ veredicto em setembro de 1912 marcaria uma ruptura estilística em seus escritos:

\begin{abstract}
A legitimidade do extremismo artístico provém essencialmente da tradição que ele nega. Hegel ensinou que, quando algo novo torna-se visível de um modo imediato, repentino e autêntico, está apenas rompendo a casca após uma longa formação. Somente aquele que se nutre das seivas da tradição tem forças para confrontá-la autenticamente; o outro tornar-se-á presa fácil de poderes que não conseguiu dominar em si mesmo. ${ }^{6}$
\end{abstract}

O Kafka anterior à ruptura estilística ficaria conhecido como "jovem Kafka": um escritor caracterizado ainda por um tom lírico e onde se notam muitas influências da chamada "Escola de Praga". O exemplo mais acabado deste primeiro Kafka pode ser encontrado na coletânea Contemplação (contendo textos produzidos desde 1904 a 1911):

Mas no caso de Contemplação a impressão que se pode ter é de estar diante de um pré-Kafka - embora temas permanentes como o isolamento do sujeito (que leva ao exílio analítico), a consciência ameaçada de dissolução (aqui visível na reincidência do man/se, que se substitui ao ich/eu) e a busca de equilíbrio através da naturalização do insólito, entre vários outros, já estejam presentes. Acontece no entanto que neste livro a língua kafkiana é outra e isso muda tudo. ${ }^{7}$

A partir de setembro de 1912, um antiornamentalismo passa a animar a escrita kafkiana. Kafka abandona o artifício verbal e sua escrita impregna-se pelo protocolo seco, absorvendo completamente o "laconismo do estilo de repartição"8. Estamos aqui, de fato, diante de uma forte inflexão em sua escrita; não sem razão, portanto, ela foi descrita por muitos críticos como "Durchbruch" ("ruptura").

\footnotetext{
${ }^{6}$ Cf. T. W. Adorno, "Arnold Schoenberg (1874-1951)", em Prismas, p. 152, grifo meu.

7 M. Carone, "Um primeiro livro lírico e uma novela impecável" (Posfácio), em F. Kafka, Contemplação/Foguista, p. 91, grifos meus.

${ }^{8}$ M. Carone, "Um primeiro livro lírico e uma novela impecável" (Posfácio), em F. Kafka, Contemplação/O Foguista, p. 93.
} 
Ao alternar fases de intensa criação artística com períodos de completa estagnação literária, a produção kafkiana posterior a esta ruptura, ou seja, a produção madura deste escritor acaba, sintomaticamente, por assumir em seu aspecto geral a figura de um conjunto de "muralhas parciais" ("Teilmauern"), tal como exposto na narrativa Durante a construção da Muralha da China. ${ }^{9}$ Será precisamente através destes "blocos" produtivos que se desdobrará então a custosa evolução literária de Kafka. Grosso modo, esta produção deixa-se, por sua vez, dispor em seis ciclos produtivos: escritos produzidos entre setembro de 1912 e janeiro de 1913 (primeiro ciclo); escritos produzidos entre agosto de 1914 e janeiro de 1915 (segundo ciclo); escritos produzidos entre novembro de 1916 e maio de 1918 (terceiro ciclo); escritos produzidos entre agosto e dezembro de 1920 (quarto ciclo); escritos produzidos entre fevereiro e dezembro de 1922 (quinto ciclo); e, por fim, escritos produzidos entre novembro de 1923 e abril de 1924 (sexto ciclo).

Com a escrita de $O$ veredicto em setembro de 1912 inicia-se portanto o primeiro ciclo produtivo do chamado "Kafka maduro". Para Canetti, por exemplo, Kafka, a partir de O veredicto [setembro 1912] e O foguista [setembro 1912], adquire "inteiramente sua própria personalidade": "Quase mais relevante ainda, neste contexto, parece o fato de ele ter plena consciência do valor dessas duas obras." ${ }^{10}$ Em fins de dezembro de 1912, tendo em vista dificuldades relacionadas à escrita de $O$ desaparecido, este primeiro grande surto criativo começa a estancar e interrompe-se definitivamente com o abandono do romance no final de janeiro de 1913. Assim se encerra este primeiro ciclo de escritos posteriores à ruptura e atravessado de ponta a ponta pela escrita de $O$ desaparecido: Kafka se ocupou deste romance desde o final de setembro de 1912 até o final de janeiro de 1913. Ao longo de todo período, Kafka apenas interrompeu o trabalho no romance para a escrita de $A$ metamorfose [novembro 1912]. Com o abandono de $O$ desaparecido inicia-se então um período de esterilidade criativa que perdurará até julho de 1914.

Após mais de um ano de estagnação da produção literária, um novo ciclo inicia-se em agosto de 1914 com a escrita de O processo e se estenderá até janeiro de 1915.

\footnotetext{
${ }^{9}$ Cf. F. Kafka, F. Kafka, "Oktavheft C" [Beim Bau der chinesischen Mauer], em KKA N1, p. 337:
}

Es geschah dies so, daß Gruppen von etwa zwanzig Arbeitern gebildet wurden, welche eine Teilmauer von etwa fünfhundert Metern Länge aufzuführen hatten, eine Nachbargruppe baute innen dann eine Mauer in gleicher Länge entgegen. Nachdem dann aber die Vereinigung vollzogen war, wurde nicht etwa der Bau am Ende dieser tausend Meter wieder fortgesetzt, vielmehr wurden die Arbeitergruppen wieder in ganz andere Gegenden zum Mauerbau verschickt.

Sucedeu assim que foram formados grupos de aproximadamente vinte trabalhadores que precisavam erguer uma muralha parcial de quinhentos metros de comprimento, enquanto um grupo vizinho construía em sua direção outra muralha do mesmo comprimento. Mas depois de completada a união não se prosseguiu mais a construção no final desses mil metros; em vez disso os grupos de trabalhadores foram deslocados para regiões totalmente diferentes visando à construção da muralha.

(F. Kafka, Durante a construção da Muralha da China, em NE, p. 73.)

${ }^{10}$ E. Canetti, O outro processo, p. 25. 
Trata-se, a exemplo do ciclo posterior à "ruptura", de uma segunda grande fase criativa do escritor. Durante este novo ciclo de escritos, concomitantemente portanto ao trabalho em $O$ processo, Kafka retoma também o trabalho em $O$ desaparecido, escrevendo em agosto o fragmento "Partida de Brunelda" [agosto 1914] e em outubro (paralelo ainda à escrita de Na colônia penal) o fragmento intitulado por Max Brod "O $\underline{O}$ teatro natural de Oklahoma" [outubro 1914] ${ }^{11}$. Uma espécie de ligação com o ciclo anterior expressa-se na concepção de um "livro de novelas", desta vez intitulado Punições (Strafen) e que reuniria as novelas O veredicto [setembro 1912], A metamorfose [novembro 1912] e Na colônia penal [outubro 1914]; a exemplo de um primeiro projeto (Os filhos/Die Söhne), este plano também fracassou. Sabe-se que o famoso editor Kurt Wolff nunca tomou este projeto de um "livro de novelas" por um "livro vendável" e pretendia publicar separadamente $\mathrm{Na}$ colônia penal, como já havia feito com $O$ foguista e $A$ metamorfose e haveria de fazer no ano seguinte com $O$ veredicto. Devido a inúmeros impasses, $\mathrm{Na}$ colônia penal acabou sendo publicada apenas em 1919. Ao insistir na ordem das narrativas no interior do projeto, o escritor não apenas demonstrava reconhecer uma gradação entre elas ${ }^{12}$, mas mostrava-se consciente das alterações sofridas por sua produção durante o período e que culminavam em O processo [agosto 1914-janeiro 1915] e Na colônia penal [outubro 1914]. Nesse sentido, o crítico Modesto Carone anotou:

\footnotetext{
Segundo alguns estudiosos, as três grandes narrativas [ $O$ veredicto, $A$ metamorfose e Na colônia penal] mostram uma progressão temática cujos saltos podem ser cobertos não só pelo título Punições, como também pela posição que a figura do pai ocupa na seqüência imaginada por Kafka. Com efeito, o pai aparece isolado em $O$ veredicto, apoiado pela família em $A$ metamorfose e distribuído por dois sistemas concorrentes em $\mathrm{Na}$ colônia penal. O ponto intermediário entre a primeira e a última, representado por $A$ metamorfose, marca a transição do que ainda é pessoal para o que vai deixar de sê-lo, fenômeno que um crítico descreveu como "burocratização da figura paterna". Seria essa, na realidade, a reta de chegada para a trama de $O$ processo (escrito no mesmo ano de Na colônia penal), uma vez que neste a função de culpar, condenar e proceder à execução se transfere das mãos do patriarca para uma instância anônima - o Tribunal. $^{13}$
}

\footnotetext{
${ }^{11}$ Em outubro de 1914, após a escrita do fragmento intitulado por Max Brod "O teatro natural de Oklahoma", $O$ desaparecido será definitivamente engavetado.

${ }^{12}$ Em carta escrita a Georg Heinrich Meyer (diretor da Editora Kurt Wolff), em 19 de agosto de 1916, Kafka assinala a existência de uma unidade "secreta" entre as narrativas.

${ }^{13}$ M. Carone, "Duas novelas de primeira" (Posfácio), em F. Kafka, O veredicto/Na colônia penal, p. 75. Cf. também E. Canetti, O outro processo, p. 89: "No Processo, a humilhação emana de uma instância superior, infinitamente mais complexa do que a família da Metamorfose."
} 
Com o abandono de O processo no final de janeiro de 1915, mais um longo período de estagnação produtiva teria então início e iria se arrastar até o final de novembro de 1916, durando assim quase dois anos.

Em novembro de 1916 inaugura-se um terceiro e poderoso ciclo produtivo. Todos estes escritos encontram-se nos chamados "cadernos in-oitavo" ("Oktavhefte") e deixamse, por sua vez, agrupar em dois momentos produtivos distintos: novembro de 1916 a abril de 1917 - os quatro primeiros "cadernos in-oitavo" contendo todas as narrativas que integram Um médico rural (com exceção de "Diante da lei" e "Um sonho"), "A ponte", "으 caçador Graco", "O cavaleiro do balde", Durante a construção da Muralha da China e inúmeros outros pequenos fragmentos - e agosto de 1917 a maio de 1918 - os últimos quatro "cadernos in-oitavo" contendo textos como "Uma confusão cotidiana", "A verdade sobre Sancho Pança", "O silêncio das sereias", "Prometeu", além também de aforismos e vários outros fragmentos. Abandonando aquele empenho quase obsessivo de escrita de um romance que havia dominado os dois ciclos produtivos anteriores, a produção de Kafka inclinava-se sensivelmente para o que o próprio escritor chamaria de "prosa pequena" ("kleine Prosa") ${ }^{14}$. A exemplo da espantosa contração da vida na memória do avô em "A próxima aldeia" [dezembro 1916/janeiro 1917], uma das "pequenas narrativas" mais notáveis deste ciclo produtivo:

\footnotetext{
Mein Großvater pflegte zu sagen: "Das Leben ist erstaunlich kurz. Jetzt in der Erinnerung drängt es sich mir so zusammen, daß ich zum Beispiel kaum begreife, wie ein junger Mensch sich entschließen kann ins nächste Dorf zu reiten, ohne zu fürchten, daß - von unglücklichen Zufällen ganz abgesehen - schon die Zeit des gewöhnlichen, glücklich ablaufenden Lebens für einen solchen Ritt bei weitem nicht hinreicht."

Meu avô costumava dizer: "A vida é espantosamente curta. Para mim ela agora se contrai tanto na lembrança que eu por exemplo quase não compreendo como um jovem pode resolver ir a cavalo à próxima aldeia sem temer que - totalmente descontados os incidentes desditosos - até o tempo de uma vida comum que transcorre feliz não seja nem de longe suficiente para uma cavalgada como essa."16
}

Renunciando a formas narrativas mais extensas, Kafka mostra-se determinado a trabalhar no âmbito estrito das "pequenas narrativas". No próximo capítulo mostraremos com mais detalhes as várias e substanciais modificações sofridas pela forma kafkiana a partir deste ciclo produtivo.

\footnotetext{
${ }^{14}$ Cf. F. Kafka, Briefe 1902-1924, p. 157 (carta de 27.07.1917 ao editor Kurt Wolff).

${ }^{15}$ F. Kafka, "Das nächste Dorf", em LA, p. 88-89.

${ }^{16}$ F. Kafka, "A próxima aldeia", em MR, p. 40.
} 
Porém, mais uma vez, Kafka entrará, a partir de maio de 1918, em outra longa crise produtiva que apenas será encerrada - mais de dois anos depois! - pelo surto criativo de 1920. Este quarto ciclo produtivo, por sua vez, irá se estender entre agosto e dezembro de1920 e sua produção encontra-se reunida em um conjunto de 51 folhas soltas, chamado pelos críticos de "Konvolut 1920": entre inúmeros outros fragmentos

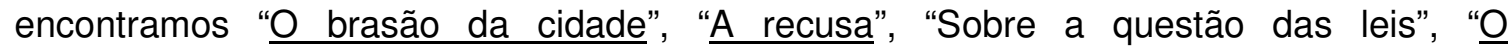

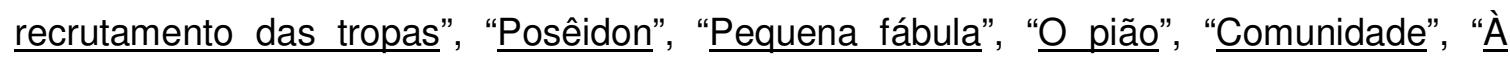
noite", "O abutre" e "A prova". Apesar do hiato de dois anos e meio, estas narrativas deixam a forte impressão de constituírem, em razão da manutenção da "prosa pequena" e da retomada de inúmeros motivos, uma espécie de desdobramento do ciclo anterior (1916-1918). Nesta direção, aliás, argumenta a crítica Schütterle ao afirmar que uma análise detida deste "Konvolut" poderia mostrar que Kafka não apenas releu por esta época os "cadernos in-oitavos" mas que este processo de leitura acaba por se tornar motor desta nova etapa produtiva. ${ }^{17}$

Já o quinto ciclo desdobra-se entre o final de janeiro e dezembro de 1922. Entre seus escritos contam-se o fragmento de romance O castelo, "Primeira dor", "Um artista da fome", "Investigações de um cão", "O casal”, "Um comentário" ("Desista!") e "Sobre os símiles".

Por fim, em novembro de 1923 inaugura-se o sexto e último ciclo produtivo de Kafka que, por sua vez, se estenderá até abril de 1924: $\underline{A}$ construção; "Volta ao lar"; "Uma pequena mulher"; "Josefina, a cantora ou o povo dos camundongos" constituem alguns de seus principais escritos. Apesar da interrupção criativa por cerca de dez meses, este ciclo de escritos poderia ser visto como uma continuação do ciclo anterior, uma vez que neste caso a interrupção da escrita fora motivada antes pela piora do seu estado de saúde do que por disposições artísticas do escritor.

Como vimos, há entre os críticos kafkianos o consenso de que o autor, a partir de setembro de 1912, rompe com uma experiência estilística anterior e consolida um modo próprio de compor ficção (no caso, a escrita de $O$ veredicto assinalaria este ponto de inflexão, caracterizado essencialmente pela absorção do chamado "estilo de repartição"). Como se pretendeu ainda assinalar nesta breve "Introdução", estes escritos posteriores à ruptura estilística não constituem, de maneira alguma, um todo homogêneo.

\footnotetext{
${ }^{17}$ Cf. A. Schütterle, Franz Kafkas Oktavhefte, p. 247.
} 
Isso posto, voltemo-nos então para o ciclo produtivo que se inicia no final de 1916 , pois como pretendemos mostrar esta produção marca, com efeito, um outro ponto de ruptura na escrita kafkiana e de desdobramentos formais tão significativos quanto aqueles que a crítica comumente assinala na ruptura de 1912. 


\title{
CAPÍTULO 1 \\ A reviravolta formal de 1916/1917
}

\author{
Man weiß nicht, was für Dinge man im eigenen \\ Hause vorrätig hat [...]. \\ (Franz Kafka, "Ein Landarzt”, 1916/1917) ${ }^{18}$ \\ Die Arbeit schließt sich, wie sich eine ungeheilte \\ Wunde schließen kann
}

(Franz Kafka, Tagebücher, 08.05.1922) ${ }^{19}$

No outono de 1916, em meio a uma crise produtiva que se arrastava por quase dois anos, o escritor Franz Kafka haveria de sofrer dois duros golpes. O primeiro deles foi a recusa, no início de outubro, do editor Kurt Wolff em publicar a novela Na colônia penal [outubro 1914], com efeito a primeira recusa direta de uma obra sua por uma editora. ${ }^{20}$ Embora a carta em que Wolff recusa a publicação de Na colônia penal tenha se perdido, a resposta de Kafka, datada de 11.10.1916, explicita o motivo alegado por Wolff para a nãopublicação do texto, a saber, o seu "caráter penoso":

\begin{abstract}
Ihr Aussetzen des Peinlichen trifft ganz mit meiner Meinung zusammen [...]. Bemerken Sie, wie wenig in dieser oder jener Form von diesem Peinlichen frei ist! Zur Erklärung dieser letzten Erzählung füge ich nur hinzu, dass nicht nur sie peinlich ist, dass vielmehr unsere allgemeine und meine besondere Zeit gleichfalls sehr peinlich war und ist und meine besondere sogar noch länger peinlich als die allgemeine. $^{21}$

A sua crítica acerca do caráter penoso coincide inteiramente com a minha opinião [...]. Repare quão pouco esta ou aquela forma estão livres deste caráter penoso! Como esclarecimento desta última narrativa acrescento apenas que não somente ela é penosa, mas que o nosso tempo em geral e o meu em particular também foram e são muito penosos - e o meu em particular ainda mais demoradamente penoso do que o tempo em geral.
\end{abstract}

\footnotetext{
${ }^{18}$ F. Kafka, "Ein Landarzt", em LA, p. 9. Trad. de Modesto Carone (F. Kafka, "Um médico rural", em Um médico rural, p. 14.): "A gente não sabe as coisas que tem armazenadas na própria casa [...]."

${ }^{19}$ F. Kafka, "Zwölftes Heft", em KKA T, p. 919 (ressalte-se que a anotação aparece exatamente desta forma no manuscrito kafkiano, ou seja, sem qualquer pontuação final): "O trabalho se fecha, como uma ferida nãocurada pode se fechar".

${ }^{20}$ Cf. J. Unseld, Franz Kafka: ein Schriftstellerleben, p. 138.

${ }^{21}$ F. Kafka, Briefe 1902-1924 [carta a Kurt Wolff], p. 150.
} 
$\mathrm{Na}$ competente análise que faz desta carta o crítico Joachim Unseld assinala a reação surpreendentemente enérgica do escritor à recusa do editor e como também pela primeira vez Kafka direciona a defesa de um texto seu para uma dimensão geral e pública (afastando-se assim da habitual argumentação baseada em razões pessoais, própria dos anos anteriores):

\footnotetext{
O "esclarecimento" dirigido ao editor - de que precisamente em Na colônia penal o caráter penoso do seu tempo em particular culminaria com o caráter penoso [do tempo] em geral; de que a narrativa, portanto, teria em razão de sua referência temporal direta um significado supra-individual - deve ser visto como outra manobra explícita do escritor em favor da publicação de Na colônia penal.. ${ }^{22}$
}

A carta de Kafka contudo não encontrou eco em Leipzig; Kurt Wolff seguiria firme na decisão de manter sua editora em tempos de guerra longe de qualquer temática bélica ou que fosse capaz de chamar a atenção da censura. O segundo golpe sofrido por Kafka viria pouco depois: o "fracasso grandioso" ("großartiger Mißerfolg") ${ }^{23}$, os termos são do próprio escritor, de sua leitura pública desta novela na Galeria Hans Goltz em Munique em 10 de novembro.

Estes últimos "fracassos" - a rigor, apenas os mais recentes em uma sucessão aparentemente infindável deles - acabariam, contudo, por cristalizar a percepção da própria produção como um campo de ruínas. Pois outro não era o quadro que então se apresentava ao escritor: desde a escrita de $O$ veredicto em setembro de 1912, sentida pelo próprio Kafka como uma espécie de ruptura literária, haviam ficado pelo caminho dois grandes romances inacabados ( $O$ desaparecido [1912-1914] e O processo [19141915]), um número assombroso de narrativas abandonadas - para mencionar apenas as mais extensas: Recordações da estrada de ferro de Kalda [agosto 1914], Um mestreescola da aldeia [dezembro 1914], Blumfeld, um solteiro de meia-idade [janeiro 1915] -, além de dois projetos frustrados de um livro de novelas (Os filhos [1913] e Punições [1915-1916]). Ainda hoje estes dois projetos de um livro de novelas são pouco considerados e em geral subestimados pela crítica; à época, porém, a importância deles aos olhos do próprio escritor nada tinha de desprezível; pelo contrário, em vista do naufrágio de seus primeiros romances, eles se apresentavam como alternativas em seu esforço, ao fim e ao cabo malogrado, de se afirmar como escritor. Nesse sentido, vale

\footnotetext{
22 J. Unseld, Franz Kafka: ein Schriftstellerleben, p. 139.

${ }^{23}$ F. Kafka, Briefe an Felice, p. 744 (carta de 07.12.1916). Cf. ainda nesta mesma carta:

Eu abusei de minha escrita transformando-a em um veículo para Munique [...] e depois de 2 anos de não-escrita tive a fantástica pretensão de ler em público enquanto há um ano e meio em Praga eu não leio nada aos meus melhores amigos.
} 
sublinhar que durante mais de três anos, ou seja, de abril de 1913 a setembro 1916, estes projetos afetaram decisivamente as relações de Kafka com a editora de Wolff, sendo que seu o fracasso não haveria por certo de passar em branco:

[...] a experiência da impossibilidade evidente de impor a própria vontade junto à editora reforçou nele [Kafka] a avaliação pessimista sobre a própria escrita entendida, a rigor, como medida de proteção. [...] no fracasso de seu livro de novelas ampliava-se a certeza de Kafka de ser apenas uma figura marginal e esquisita dentro do meio literário de seu tempo com uma posição fraca ante sua editora. $^{24}$

E a se considerar a produção anterior a setembro de 1912 - descontando-se, evidentemente, tudo o que foi destruído por Kafka em março de $1912^{25}$ - teríamos então de acrescentar aos fracassos listados acima: três versões abandonadas de Preparativos para um casamento no campo (uma datada de 1906-1907 e as outras duas de 1908); duas versões também inconclusas da novela Descrição de um combate (uma de 19071908 e a outra de 1909-1910); além de uma primeira versão, também destruída pelo próprio escritor, de $O$ desaparecido, escrita entre dezembro de 1911 e julho de 1912.

Diante, portanto, de uma produção como esta - que se desdobrava antes como uma acumulação de ruínas do que uma sucessão propriamente de obras -, fica difícil imaginar que um escritor refletido como Kafka não acabasse por tirar deste quadro desconcertante alguma lição. A estratégia empregada pelo escritor a partir do espantoso

\footnotetext{
24 J. Unseld, Franz Kafka: Ein Schriftstellerleben, p. 130.

${ }^{25}$ Em 11.03.1912 Kafka anota lacônico em seu diário: "Hoje muitos papéis velhos e repulsivos queimados." (F. Kafka, "Fünftes Heft", em KKA T, p. 400.) Há razões de sobra para se acreditar que o material destruído nesta ocasião não foi pequeno. Nesse sentido, não custa lembrar uma carta a Oskar Pollak datada ainda de 06.09.1903 (!) em que Kafka expõe ao amigo a intenção de lhe preparar uma espécie de "pequeno" caderno ("Bündel") com toda a sua produção até aquela data (cf. F. Kafka, Briefe 1902-1924, p. 18), sendo que em outra carta, escrita pouco depois, tem-se então uma idéia da quantidade deste material: "Entre as milhares [!] de linhas que entrego a você, eu poderia escutar, de modo tolerante, talvez ainda umas dez [...]. A maior parte me é repulsiva [...] (por exemplo, "Der Morgen" ["A manhã"] e outras) [...]." (apud M. Engel, "Drei Werkphasen", em B. Auerochs e M. Engel (orgs.), Kafka Handbuch, p. 82; nesta mesma carta, aliás, Kafka refere-se também a um romance do qual não há nenhum outro vestígio: "Eu precisava mesmo de dois nomes para um romance e escolhi finalmente [...]: Johannes e Beate [...].") Ainda com relação a esta produção mais antiga (ou seja, até 1903), vale assinalar - em uma anotação dos diários datada de 19.11.1911 - a referência a um outro antigo projeto de romance (possivelmente datado dos anos 1898-1899): "Certa vez eu tinha planejado um romance em que dois irmãos lutavam um contra o outro, sendo que um viajava para a América enquanto o outro permanecia em uma prisão européia." (F. Kafka, "Zweites Heft", em KKA T, p. 146.) Particularmente produtivo (e destrutivo: já que praticamente nada restou) parece também ter sido o ano de 1910: "Que eu tenha posto de lado e riscado tanta coisa, quase mesmo tudo o que eu escrevi neste ano, isto de qualquer modo me impede muito também de escrever. Trata-se de fato de uma montanha, é 5 vezes mais do que eu jamais havia escrito [...]."(F. Kafka, "Zweites Heft" [17.12.1910], em KKA T, p. 133). Por fim, não custa registrar uma das primeiras decepções experimentadas pelo jovem Kafka, a saber, a acolhida negativa de sua narrativa "Himmel in engen Gassen" ("Céu em ruelas estreitas"), da qual também não há mais vestígios, por parte dos jurados de um concurso literário promovido pelo jornal vienense Die Zeit no inverno de 1906 (Cf. J. Unseld, "Kafkas Publikationen zu Lebzeiten", em O. Jahraus (org.), Kafka Handbuch, p. 124.)
} 
ciclo produtivo que se inicia no final de novembro de 1916 constitui, sem dúvida, um testemunho deste seu aprendizado com o arcabouço há muito problemático e quebradiço de sua própria produção: Kafka irá superá-lo não ao lhe resistir, não ao ceder à sedução de uma falsa inteireza ou, nas palavras do próprio escritor, à "fabricação artificial e inútil de uma unidade que não existe"26; mas ao levar este caráter quebradiço, fragmentário mais fundo para dentro da forma. Isto quer dizer, internalizar de maneira radical a crise, o colapso de sua própria produção; expondo, ao fim e ao cabo, a má infinitude de sua própria forma. Nesse exato sentido, referimo-nos na introdução deste trabalho a uma consciência agora imanente à própria configuração literária de sua impossibilidade de chegar ao fim, ou seja, da impossibilidade de acabamento. Tratava-se portanto de um "pequeno" ajuste formal (pois, a rigor, Kafka nada mais faz do que explorar o que em certa medida já estava armazenado em sua "antiga" produção), mas de alcance, como veremos, extraordinário.

Não custa também assinalar que até mesmo os materiais empregados por Kafka no seu trabalho de escrita sofrerão alterações a partir do final de 1916. No lugar de cadernos no formato in-quarto, empregados habitualmente pelo escritor tanto para o trabalho literário quanto para a escrita dos diários, Kafka passa a fazer uso exclusivo de cadernos in-oitavo, ou seja, cadernos de dimensões reduzidas $(16,5 \mathrm{~cm}$ por $10 \mathrm{~cm})$; os quais tinham então a vantagem de serem particularmente apropriados ao transporte. Como se sabe, em fins de novembro de 1916 Kafka passa a dispor todas as noites de uma pequena casa alugada por sua irmã Ottla nos arredores do famoso Castelo de Praga para o trabalho literário sendo que no início da madrugada o escritor então retornava para o próprio apartamento na Cidade Velha. Paralelo a isso, o escritor também passa a utilizar lápis no lugar da "tradicional" pena de aço. Para o crítico Roland Reuß, a conjunção destes materiais tornaram possível uma escrita ainda mais experimental e que se punha ainda menos em concordância com as convenções literárias do que aquela dos cadernos inquarto. ${ }^{27}$

A experiência do fracasso da própria produção que, como vimos, impôs-se de forma contundente ao escritor no final de 1916 fazia-se contudo impregnada pela experiência de um outro "fracasso grandioso": após dois anos de guerra, a velha Monarquia do Danúbio exibia sinais inequívocos de uma dissolução iminente. Com o agravamento, ao longo do ano de 1916, do quadro de devastações da Primeira Guerra Mundial, a "catástrofe

\footnotetext{
${ }^{26}$ F. Kafka, Briefe an Felice, p. 374 (carta de 01.05.1913): "[...] nutzlose[s] künstliche[s] Herstellen einer Einheit, die nicht da ist."

${ }^{27}$ Cf. R. Reuß, "Die ersten beiden Oxforder Oktavhefte Franz Kafkas: eine Einführung”, em Franz Kafka-Heft 5, HKKA O1/2, p. 5.
} 
primeva" ("Urkatastrophe"28) do século XX, estes sinais já não podiam mais ser ignorados. Para tanto, não custa lembrar que três dos eventos mais sangrentos dos campos de batalha desta guerra datam precisamente do ano de 1916 ${ }^{29}$ : Verdun (fevereiro a dezembro: com mais de 700.000 baixas), Somme (julho a novembro: com mais de um milhão de mortos) e a chamada "Ofensiva Brussilow" (junho a setembro) que levou ao colapso total do front austro-húngaro na Galícia $^{30}$. Contudo, não muito distante destes abatedouros, as condições de vida da população civil no chamado "front doméstico" ("Heimatfront") também pioravam drasticamente; e isto, em larga medida, em função do aparecimento de um novo e inesperado inimigo, um inimigo que desta vez investia "contra uma camada muito mais profunda e sensível, contra o substrato biológico da própria sociedade": a fome. ${ }^{31}$ As conseqüências porém deste quadro, e este ponto foi muito bem sublinhado por Reiner Stach, ultrapassavam em muito as da privação física imediata:

Durante muito tempo a fome foi intensa, os corpos exigiam mais que propaganda; e
diante de todos os olhos o que até então ninguém poderia imaginar tornou-se fato
irrefutável: um Estado abastado e poderoso da Europa Central, um Estado com
história brilhante e ambições imperiais, não estava mais em condições de alimentar
seus próprios cidadãos. E ele os deixaria também congelar no próximo inverno [leia-
se inverno de 1916/1917; acréscimo meu], caso não acontecesse um milagre. A
sensação de um penoso desamparo físico [leibliche Unbehaustheit] espalhava-se,
uma sensação de mendigo [Bettler-Gefühl]. O choque e as rejeições psíquicas
[psychische Verwerfungen] desencadeados por este fracasso, no entanto, iam muito
além da privação física imediata. Os homens encontravam-se lançados em uma
sociedade do lobo [Wolfsgesellschaft], na qual esforço, economia e lealdade não

${ }^{28} \mathrm{O}$ termo "Urkatastrophe" aplicado à Primeira Guerra Mundial foi empregado originalmente pelo historiador George F. Kennan em Bismarcks europäisches System in der Auflösung.

${ }^{29}$ Cf. W. J. Mommsen, Die Urkatastrophe Deutschlands, p. 66-68.

${ }^{30}$ Uma tragédia maior apenas pôde ser evitada pela intervenção das tropas alemãs. A iminência do desastre de seu principal aliado na guerra levou o Império Alemão a interferir cada vez mais no comando militar austrohúngaro. Esta crescente influência alemã, porém, faria com que as tensões internas do chamado "império de muitos povos" ("Vielvölkerreich") atingissem um ponto crítico, pois como bem assinala Rauchensteiner "se as nacionalidades não-alemãs da Monarquia haviam acreditado reconhecer nesta guerra um sentido, este então seria o de que o Estado multinacional [Vielvölkerstaat] haveria de se manter e que as condições de vida para todas as nacionalidades deveriam melhorar. Em hipótese alguma, no entanto, as nacionalidades não-alemãs queriam levar a cabo uma guerra como 'vassalos' do Império Alemão e se sacrificar pelos objetivos de guerra imperialistas das potências centrais." (M. Rauchensteiner, "Österreich im Ersten Weltkrieg 1914-1918", em M. Gehler e R. Steininger (orgs.), Österreich im 20.Jahrhundert: von der Monarchie bis zum Zweiten Weltkrieg, p. 74.)

31 R. Stach, Kafka: Die Jahre der Erkenntnis, p. 162. Não custa assinalar também o comentário de Rauchensteiner: "Desde 1916 a fome grassava na Áustria e havia apertos [Engpässe] em todas as esferas da vida. As forças de trabalho estavam do mesmo modo como os soldados no fim de sua capacidade produtiva [Leistungsfähigkeit]. Nos estabelecimentos industriais trabalhava-se até 110 horas por semana [!], a fim de assegurar a demanda dos fronts." (M. Rauchensteiner, "Österreich im Ersten Weltkrieg 1914-1918", em M. Gehler e R. Steininger (orgs.), Österreich im 20.Jahrhundert: von der Monarchie bis zum Zweiten Weltkrieg, p. 75-76.) 
mais eram recompensados. Ao invés disso, exigiam-se astúcias sociais e habilidade de se impor de forma desavergonhada [dreistes Durchsetzungvermögen], flexibilidade e boas relações. Isso significava contudo a dissolução [Auflösung], senão mesmo a inversão [Umkehrung], do sistema de valores burgueses - uma catástrofe moral, que desencadeava angústia e desespero. ${ }^{32}$

Tratava-se, portanto, de um contexto, para nos valermos mais uma vez de palavras do próprio escritor, no qual "as belas imagens volatilizavam-se gradativamente com o agravamento da fome [...]. [...]. Um tempo mau, realmente mau!" ("Die schönen Bilder verflüchtigten sich allmählich mit dem Ernster-werden des Hungers [...]. [...]. Eine böse, böse Zeit!") $)^{33}$.

Não bastasse esta conjuntura já em si desesperadora, um outro acontecimento acabaria ainda por sacudir este império agonizante e enterrar definitivamente qualquer esperança de uma volta à "normalidade": a morte em 21 de novembro de 1916 do imperador Francisco José. Com a sua morte chegava ao fim um reinado que havia se estendido por longos 68 anos e que, de um modo geral, fora também sentido pelos cidadãos deste império como uma era de relativa estabilidade. $O$ impacto da perda desta figura para a chamada Monarquia do Danúbio não foi, de fato, pequeno e apenas pode ser satisfatoriamente dimensionado se tivermos em conta uma das características mais peculiares deste Estado, qual seja, a sua configuração multinacional:

\begin{abstract}
Das übernationale Ideal, das noch in der väterlichstrengen Anfangswendung der Proklamationen Franz Josefs "An meine Völker" Ausdruck findet, war das ideologische Fundament der Donaumonarchie, ihre geistige und propagandistische Stütze im Kampfe gegen das moderne Erwachen der nationale Kräfte, kurz, eine Waffe des habsburgischen Kampfes gegen die Geschichte. ${ }^{34}$
\end{abstract}

E embora, desde o final do século XIX e início do XX, a convivência entre os seus vários povos estivesse se tornando cada vez tensa e conflituosa; não há como negar que

\footnotetext{
${ }^{32}$ R. Stach, Kafka: Die Jahre der Erkenntnis, p. 164. Para mais um vislumbre deste quadro de deterioração das condições de vida das populações dos impérios centrais (Império Alemão e Império Austro-Húngaro) ao longo do ano de 1916, veja, por exemplo, a carta da mãe de Kafka, Julie Kafka, a Felice Bauer na qual afirma que o jejum do Yom Kipur daquele ano (1916) não havia sido difícil "pois nós treinamos para isto o ano inteiro" (ou seja, mesmo para uma família relativamente abastada como os Kafka, a situação já era bastante preocupante): "Das Fasten wurde uns nicht schwer, da wir uns schon das ganze Jahr dazu trainieren."/"O jejum não foi difícil, pois nós treinamos para isto o ano inteiro." (F. Kafka, Briefe an Felice, p. 721 [carta de Julie Kafka a Felice datada de 08.10.1916].)

${ }^{33}$ Cf. F. Kafka, [Forschungen eines Hundes] [Investigações de um cão], em KKA N2, p. 470. Cf. também F. Kafka, "Hungerkünstlerheft" [“Ein Hungerkünstler"], em KKA N2, p. 397-398:

Versuche jemandem die Hungerkunst zu erklären! Wer es nicht fühlt, dem kann man es nicht begreiflich machen.

Tente explicar a alguém a arte de passar fome! Não se pode explicá-la para quem não a sente. (F. Kafka, "Um artista da fome", em $A F / C$, p. 33-34).

${ }^{34}$ C. Magris, Der Habsburgische Mythos in der österreischischen Literatur, p. 12.
} 
Francisco José fora, ainda assim, capaz de atuar como uma espécie de instância integradora, garantindo e mantendo este "cosmo" fechado. ${ }^{35}$ A expressiva perda de influência internacional da Monarquia do Danúbio a partir de meados do século XIX é, como se sabe, um consenso entre os historiadores. Para tanto, basta pensar nos fracassos estrondosos da política externa austríaca materializados, a seu turno, nas derrotas militares para Itália e França em 1859 e para Prússia em 1866. Assinale-se ainda que esta derrota para a Prússia na chamada "Bruderkrieg" foi particularmente amarga e decretaria o fim da "Confederação Alemã" ("Deutscher Bund"), criada em 1815 durante o Congresso de Viena (como uma espécie de sucedâneo do antigo Sacro Império Romano Germânico, dissolvido por Napoleão) e até então sob a batuta da Áustria. Para sobreviver, o combalido Império Habsburgo precisou ceder aos interesses húngaros em 1867: com a assinatura do chamado "Ausgleich”/“Compromisso" (entre Francisco José e a delegação húngara liderada por Ferenc Deák) tem-se então o início oficial do chamado Império Austro-Húngaro. A grande ironia aqui consiste no fato de que reconhecer apenas os interesses húngaros significava, ao mesmo tempo, ignorar as reivindicações de todas as outras nacionalidades deste "império de muitos povos"; não é de se espantar, portanto, que as tensões internas não fizessem senão aumentar. Para o bem ou para o mal, no entanto, este "Estado de muitos povos" haveria de se manter ainda por mais de cinqüenta anos (e não fosse a Primeira Guerra Mundial que atuaria como catalisador das tensões internas deste império, impossível dizer por quanto tempo ele ainda teria se mantido); esta fórmula da política interna posta em prática pelos Habsburgo para sustentar o que parecia insustentável - uma distribuição calculada, ponderada da insatisfação entre as diferentes nacionalidades - foi chamada com felicidade pelo historiador austríaco Höbbelt de "insatisfação bem-temperada" ("wohltemperierte Unzufriedenheit") ${ }^{36}$.

Porém, com o desmoronamento da figura do "grande mediador" Francisco José, o que se seguiu não foi outra coisa senão um convulsivo quadro de vácuo político ${ }^{37}$;

${ }^{35}$ Cf. L. Decloedt, "Mythos und Anti-Mythos: eine Einführung", em L. Decloedt (org.), An meine Völker: die
Literarisierung Franz Joseph I., p. 8 .
${ }^{36}$ Cf. L. Höbbelt, "Wohltemperierte Unzufriedenheit': Österreichische Innenpolitik 1908-1918", em M. Cornwall
(org.), Die letzten Jahre der Donaumonarchie, p. 58-84.
${ }^{37}$ Não custa lembrar que Francisco José sempre fora tomado como instância supra-partidária ("Instanz
jenseits der Parteien") e "não apenas pelos liberais progressistas, em especial os liberais judeus, em tempos
de antiliberalismo e antisemitismo crescentes. Até mesmo sustentáculos proeminentes do movimento dos
trabalhadores e da mobilização social-cristã da pequena burguesia respeitavam o monarca como instituição."
Cf. W. Weiss, "Zur Kulturgeschichte der Zeit Franz Josephs in Österreich", em J. Szabó et alii (orgs.)
Kakanien: Aufsätze zur österreichischen und ungarischen Literatur, Kunst und Kultur um die
Jahrhundertwende, p. 61 . Cf. também R. Stach, Kafka: Die Jahre der Erkenntnis, p. 165: "Ele foi o grande
mediador [großer Mittler], o último ponto de referência comum, atrás do qual o caos ameaçava e cujo
significado por isso mesmo ninguém ousava colocar em questão. Era inimaginável que um dos partidos
pudesse tê-lo atacado, ainda menos na forma de uma agressão física, como havia acontecido [...] em outubro 
momento então em que as inúmeras fraturas desta configuração estatal passaram a ficar mais do que nunca expostas. Não por acaso, portanto, o motivo do monarca morto vem sintomaticamente à tona em inúmeros textos do ciclo produtivo que se inicia no final de novembro de 1916 como "O novo advogado" [janeiro/fevereiro 1917], nada menos que o pórtico do volume Um médico rural, ou "Uma mensagem imperial" [março de 1917], uma das narrativas centrais desta mesma coletânea:

\begin{abstract}
Heute - das kann niemand leugnen - gibt es keinen großen Alexander. Zu morden verstehen zwar manche; [...] aber niemand, niemand kann nach Indien führen. Schon damals waren Indiens Tore unerreichbar, aber inre Richtung war durch das Königsschwert bezeichnet. Heute sind die Tore ganz anderswohin und weiter und höher vertragen; niemand zeigt die Richtung; viele halten Schwerter, aber nur, um mit innen zu fuchteln; und der Blick, der innen folgen will, verwirrt sich. ${ }^{38}$

Hoje - isso ninguém pode negar - não existe nenhum grande Alexandre. É verdade que muitos sabem matar; [...] mas ninguém, ninguém, sabe guiar até a Índia. Já naquela época as portas da Índia eram inalcançáveis, mas a direção estava assinalada pela espada do rei. $\underline{\text { Hoje }}$ as portas estão deslocadas para um lugar completamente diferente, mais longe e mais alto; ninguém mostra a direção; muitos seguram espadas, mas só para brandi-las; e o olhar que quer segui-las se confunde. $^{39}$

Der Kaiser - so heißt es - hat Dir [...], gerade Dir hat der Kaiser von seinem Sterbebett aus eine Botschaft gesendet. [...]. Und vor der ganzen Zuschauerschaft seines Todes [...] vor allen diesen hat er den Boten abgefertigt. ${ }^{40}$

O imperador - assim consta - enviou a você [...], exatamente a você o imperador enviou do leito de morte uma mensagem. [...]. E perante a todos os que assistem à sua morte [...], perante todos eles o imperador despachou o mensageiro. ${ }^{41}$
\end{abstract}

Mais adiante (em 2 de dezembro de 1917), ou seja, já em um segundo momento deste mesmo ciclo produtivo, Kafka volta mais uma vez a este motivo:

Es wurde innen die Wahl gestellt Könige oder der Könige Kuriere zu werden. Nach Art der Kinder wollten alle Kuriere sein. Deshalb gibt es lauter Kuriere, sie jagen durch die Welt und rufen da es keine Könige gibt, einander selbst die sinnlos

de 1916 com o imperial e real [k.u.k.] Primeiro Ministro Karl Graf Stürckh [Karl Graf Stürckh foi assassinado em 21 de outubro de 1916, exatamente um mês antes da morte de Francisco José, pelo filho do líder da Social-Democracia; acréscimo meu]. Mesmo entre os nacionalistas mais agressivos eram até então apenas poucos que imaginavam um mundo pós-guerra sem a Monarquia Habsburgo."

${ }^{38}$ F. Kafka, "Der neue Advokat", em $L A$, p. 3-4.

${ }^{39}$ F. Kafka, "O novo advogado", em MR, p. 11-12.

${ }^{40}$ F. Kafka, "Eine kaiserliche Botschaft", em $L A$, p. 90-92, grifos meus.

${ }^{41}$ F. Kafka, "Uma mensagem imperial", em MR, p. 41. 
gewordenen Meldungen zu. Gerne würden sie ihrem elenden Leben ein Ende machen, aber sie wagen es nicht wegen des Diensteids. ${ }^{42}$

Há que se destacar, porém, ainda dentro daquele primeiro momento a aparição de uma variante deste motivo, a saber, o esvaziamento da figura do monarca: nesse sentido, vale sublinhar a impotência do imperador de "Uma folha antiga" [março 1917] que, da janela de seu palácio, assiste "de cabeça baixa"/"mit gesenktem Kopf", o movimento dos nômades que tomaram de assalto a praça em frente ao seu castelo e a transformaram em uma "verdadeira estrebaria" ("wahrer Stall").

Tratava-se portanto de um momento particularmente penoso para os cidadãos da velha Monarquia do Danúbio, um momento em que o "deserto do real”43 parecia assim irromper violentamente em meio ao chamado "mito habsburgo"44, o qual, a seu turno, havia conseguido transformar a problemática e contraditória realidade deste império em uma "época dourada": "[...] época dourada da segurança. Tudo em nossa monarquia austríaca quase milenar parecia fundado na duração e o próprio Estado o garantidor supremo desta permanência. [...]. Tudo tinha sua norma, sua medida definida e peso." ${ }^{45}$.

Dito isso e concentrando-se mais uma vez na produção de Kafka que se inicia no final de novembro de 1916, atente-se então não para uma simples coincidência destas duas experiências - a cristalização da experiência do colapso da própria produção e a experiência do colapso da velha Monarquia do Danúbio em meio aos horrores da Primeira Guerra Mundial - mas, antes, para a convergência delas na reorganização radical de seus esforços produtivos levada a cabo pelo escritor neste exato momento. A estratégia empreendida pelo escritor será a de levar esta dupla experiência mais fundo para dentro de sua própria forma; o que significava portanto internalizar tanto a crise que já estava dada no plano da própria produção quanto aquela em marcha no plano histórico. Estas duas dinâmicas de crise constituem portanto o fundamento da reviravolta formal que se materializa na produção de Kafka neste momento.

Que Kafka não estava, em absoluto, indiferente a este contexto de convulsão social e política fica evidente se se notar como este novo ciclo produtivo - cujo o início coincide não por acaso com a morte do "Über-Vater" ("Super-pai”) da Monarquia do Danúbio passa a se desdobrar explorando de maneira ostensiva o motivo do que aqui chamarei de

\footnotetext{
${ }^{42}$ F. Kafka, "Oktavheft G", em KKA N2, p. 56, grifo meu.

${ }^{43}$ Empresto o termo de S. Žižek (cf. Bem-vindo ao deserto do real!).

${ }^{44}$ Cf. C. Magris, Der habsburgische Mythos in der Österreichischen Literatur.

45 S. Zweig [Die Welt von Gestern, 1940-1941] apud C. Magris, Der habsburgische Mythos in der Österreichischen Literatur, p. 7: "[...] goldenes Zeitalter der Sicherheit. Alles in unserer fast tausendjährigen österreichischen Monarchie schien auf Dauer gegründet und der Staat selbst der oberste Garant dieser Beständigkeit. [...]. Alles hatte seine Norm, sein bestimmtes Maß und Gewicht."
} 
corpo danificado. Trata-se a partir deste ponto de uma exploração quase obsessiva da imagem de um corpo a se desintegrar, sendo que ao redor deste motivo passam a gravitar inúmeras outras imagens correlatas como as do dilaceramento, do sangue e da morte (além da imagem ainda mais aterradora da própria morte sob o signo da lesão, ou seja, de uma morte danificada). É como se o projeto estético-literário do escritor fosse então radicalmente atravessado pela intenção de expor esta ferida; uma ferida que, no âmbito conotativo, não se limitava de forma alguma apenas à velha Áustria, mas dizia respeito a toda Europa: "[...] den Vorhang zu heben und die Wunde zu zeigen."/“[...] levantar a cortina e expor a ferida." ${ }^{46}$ Para que tenhamos uma percepção mais concreta disso, vale a pena destacar, ainda que de uma maneira sucinta, a assombrosa recorrência deste motivo. A breve apresentação a seguir mantém-se atenta à sucessão cronológica dos textos.

\footnotetext{
${ }^{46}$ F. Kafka, "Oktavheft F" ["Vom jüdischen Teater"], em KKA N1, p. 424. A citação acima foi extraído de um pequeno texto esboçado pelo ator Isaak Löwy sobre a sua relação com o teatro judaico e retrabalhado por Kafka (a pedido do próprio ator). O esboço original enviado por Löwy a Kafka se perdeu; nesse sentido fica difícil determinar a exata participação do escritor no texto final; a brevíssima introdução (de onde aliás retiramos a citação acima) que precede as recordações de Löwy foi, porém, certamente escrita por Kafka (por volta do final de setembro de 1917) e se deixa mesmo ler em estreita relação com os demais cadernos inoitavo (e evidentemente com a coletânea Um médico rural). A este respeito, cf. KKA N1 App, p. 96-99.
} 


\section{Ulcus tangere}

Em "Sonho dilacerado" [novembro 1916], um dos dois pequenos fragmentos narrativos que marcam a retomada da escrita após uma paralisia de quase dois anos, deparamo-nos com a sintomática figura de um inválido de guerra:

Ein Invalide aus einem Krieg des vorigen Jahrhunderts, Witwer und Vater dreier Söhne, die im letzten Krieg gefallen waren [...]. [...]. Bis zur Allee, welche dann geradeaus zum Mausoleum führte, hielt der Invalide trotz seiner Stelze mit dem Hofbeamten gleichen Schritt.

Um inválido de uma guerra do século passado, viúvo e pai de três filhos, que haviam tombado na última guerra [...]. [...]. Até a alameda, que então levava em linha reta ao mausoléu, o inválido manteve apesar de sua muleta o mesmo passo do funcionário da corte. ${ }^{47}$

A propósito, o próprio título deste pequeno fragmento, escrito três ou quatro dias após a morte do imperador Francisco José, já é por si só significativo.

Em "Um médico rural" [dezembro 1916/janeiro 1917], o médico-narrador não se furta à tarefa de descrever de forma meticulosa "à distância" ("aus der Entfernung") e "de perto" ("in der Nähe") a ferida do jovem doente:

In seiner rechten Seite, in der Hüftengegend hat sich eine handtellergroße Wunde aufgetan. Rosa, in vielen Schattierungen, dunkel in der Tiefe, hellwerdend zu den Rändern, zartkörnig, mit ungleichmäßig sich aufsammelndem Blut, offen wie ein Bergwerk obertags. So aus der Entfernung. In der Nähe zeigt sich noch eine Erschwerung. Wer kann das ansehen ohne leise zu pfeifen? Würmer, an Stärke und Länge meinem kleinen Finger gleich, rosig aus eigenem und außerdem blutbespritzt, winden sich, im Innern der Wunde festgehalten, mit weißen Köpfchen, mit vielen Beinchen ans Licht. ${ }^{48}$

No seu lado direito, na região dos quadris, abriu-se uma ferida grande como a palma da mão. Rosa, em vários matizes, escura no fundo, tornando-se clara nas bordas, delicadamente granulada, com o sangue coagulado de forma irregular, aberta como a boca de uma mina à luz do dia. Assim à distância. De perto mostra mais uma complicação. Quem pode olhar para isso sem dar um leve assobio?

\footnotetext{
${ }^{47}$ F. Kafka, "Oktavheft A" ["Zerrissener Traum"], em KKA N1, p. 267-268. Na introdução que escreveu para a edição dos dois primeiros cadernos in-oitavo, Roland Reuß, ao comentar o texto supracitado, chama a atenção para o dado de que a semântica do substantivo "Stelze" oscila entre apoio material ("stützendes Hilfsmittel") e prótese ("Prothese"): "Die Rede von der 'Stelze' kann demnach auf eine Amputation hindeuten, sie muß es aber nicht." ("Die ersten beiden Oxforder Oktavhefte Franz Kafkas: eine Einführung”, em Franz Kafka-Heft 5, HKKA 01/2, p. 16). Optei por traduzir "Stelze" por "muleta", a outra possibilidade - que não deve ser descartada - seria então "perna de pau" (neste caso a amputação de uma das pernas ou de parte dela estaria pressuposto).

${ }^{48}$ F. Kafka, "Ein Landarzt", em LA, p. 23-24 (grifos meus).
} 
Vermes da grossura e comprimento do meu dedo mínimo, rosados por natureza e além disso salpicados de sangue, reviram-se para a luz, presos no interior da ferida, com cabecinhas brancas e muitas perninhas. ${ }^{49}$

Em "Na galeria" [dezembro 1916/janeiro 1917], como ignorar o fato de que se trata de uma "amazona frágil e tísica" ("hinfällige, lungensüchtige Kunstreiterin"50)? A lesão portanto se apresenta aqui - mesmo que encoberta (pois "oculta" nos pulmões) - no centro do picadeiro.

\section{Em "Um fratricídio" [dezembro 1916/janeiro 1917]:}

Und rechts in den Hals und links in den Hals und drittens tief in den Bauch sticht Schmar. Wasserratten, aufgeschlitzt, geben einen ähnlichen Laut von sich wie Wese. "Getan", sagt Schmar und wirft das Messer, den überflüssigen blutigen Ballast, gegen die nächste Hausfront. "Seligkeit des Mordes! Erleichterung, Beflügelung durch das Fließen des fremden Blutes!"

E à direita e à esquerda no pescoço e uma terceira vez fundo no ventre perfura Schmar. Roedores rasgados por uma lâmina emitem um som semelhante ao de Wese. "Pronto" diz Schmar e atira a faca, o supérfluo lastro ensangüentado, em direção à próxima fachada. "Oh, bem-aventurança do assassinato! Alívio, alada ascensão alimentada pelo escorrer do sangue do outro!" ${ }^{\text {"2 }}$

\section{Em "A ponte" [janeiro 1917]:}

[...] ohne abzustürzen kann keine einmal errichtete Brücke aufhören Brücke zu sein. [...]. Und ich drehte mich um, inn zu sehn. Brücke dreht sich um! Ich war noch nicht umgedreht, da stürzte ich schon, ich stürzte und schon war ich zerrissen und aufgespießt von den zugespitzten Kieseln, die mich so friedlich immer angestarrt hatten aus dem rasenden Wasser. ${ }^{53}$

Uma vez erguida, nenhuma ponte pode deixar de ser ponte sem desabar. [...]. E virei-me para vê-lo. Uma ponte que se vira! Eu ainda não tinha me virado e já estava caindo, caí, já estava dilacerado e trespassado pelos cascalhos afiados, que sempre me haviam fitado tão pacificamente da água enfurecida. ${ }^{54}$

\section{Em "O caçador Gracchus" [janeiro/fevereiro 1917]:}

Alles ging der Ordnung nach. Ich verfolgte, stürzte $a b$, verblutete in einer

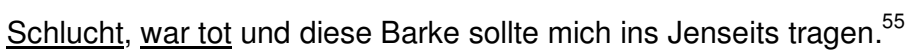

\footnotetext{
${ }^{49}$ F. Kafka, "Um médico rural", em MR, p. 18 (tradução ligeiramente modificada).

${ }^{50}$ F. Kafka, "Auf der Galerie", em $L A$, p. 34, grifo meu.

${ }^{51}$ F. Kafka, "Ein Brudermord", em LA, p. 131-132, grifos meus.

${ }^{52}$ F. Kafka, "Um fratricídio", em MR, p. 55 (tradução modificada).

${ }^{53}$ F. Kafka, "Oktavheft B" ["Die Brücke"], em KKA N1, p. 304-305, grifos meus.

${ }^{54}$ F. Kafka, "A ponte", em NE, p. 64-65 (tradução modificada).

${ }^{55}$ F. Kafka, "Oktavheft B" ["Der Jäger Gracchus"], em KKA N1, p. 312, grifos meus.
} 
Tudo seguia uma ordem. Eu estava perseguindo, caí, sangrei num barranco, morri, e esta barca deveria me transportar para o Além. ${ }^{56}$

\section{Em "Chacais e árabes" [janeiro/fevereiro 1917]:}

"Frieden müssen wir [Schakale] haben von den Arabern; atembare Luft [...]; kein Klagegeschrei eines Hammels, den der Araber absticht; ruhig soll alles Getier krepieren; ungestört soll es von uns leergetrunken und bis auf die Knochen gereinigt werden. [...]. Darum, o Herr, [...], mit Hilfe deiner alles vermögenden Hände schneide ihnen mit dieser Schere die Hälse durch!"

[...].

Vier Träger kamen und warfen den schweren Kadaver vor uns hin. Kaum lag er da, erhoben die Schakale ihre Stimmen. Wie von Stricken unwiderstehlich jeder einzelne gezogen, kamen sie [...]. [...] die alles auslöschende Gegenwart des stark ausdunstenden Leichnams bezauberte sie. Schon hing einer am Hals und fand mit dem ersten Biß die Schlagader. Wie eine kleine rasende Pumpe, die ebenso unbedingt wie aussichtslos einen übermächtigen Brand löschen will, zerrte und zuckte jede Muskel seines Körpers an ihrem Platz. Und schon lagen in gleicher Arbeit alle auf dem Leichnam hoch zu Berg. [...]. Sie hoben die Köpfe; halb in Rausch und Ohnmacht; sahen die Araber vor sich stehen; bekamen jetzt die Peitsche mit den Schnauzen zu fühlen; zogen sich im Sprung zurück und liefen eine Strecke rückwärts. Aber das Blut des Kamels lag schon in Lachen da, rauchte empor, der Körper war an mehreren Stellen weit aufgerissen. Sie konnten nicht widerstehen; wieder waren sie da [...]. ${ }^{57}$

"Nós [chacais] precisamos de paz com os árabes, de ar respirável [...]; nenhum grito de lamúria de um carneiro que o árabe degola; todos os animais devem morrer tranqüilamente, bebidos por nós sem transtorno ao ponto de ficarem vazios e limpos até os ossos. [...]. Por isso, senhor, [...], com a ajuda destas mãos que tudo podem, corte-lhes de lado a lado os pescocos com esta tesoura!"

$[\ldots]$.

Quatro carregadores chegaram a atiraram o pesado cadáver diante de nós. Mal ele jazia ali os chacais levantaram suas vozes. Como que puxados irresistivelmente por cordas, cada um deles veio se aproximando [...]. [...] fascinava-os a presença do corpo que exalava um cheiro forte e obliterava tudo. Um deles já se pendurava no pescoço e encontrava a jugular com a primeira mordida. Como uma bomba frenética que quer apagar um incêndio poderoso de uma maneira tão absoluta quanto sem perspectiva, cada músculo do seu corpo se estirava e contraía no respectivo lugar. E logo todos se amontoavam sobre o cadáver fazendo o mesmo trabalho. [...]. Os chacais ergueram as cabeças, meio ébrios e meio desmaiados; viram então os árabes em pé diante deles; começaram então a sentir o chicote com os focinhos; recuaram num salto e

\footnotetext{
${ }^{56}$ F. Kafka, "O cacador Gracchus", em NE, p. 71.

${ }^{57}$ F. Kafka, "Schakale und Araber", em $L A$, p. 67-74, grifos meus.
} 
correram um trecho para trás. Mas o sangue do camelo já se espalhava em poças e fumegava, o corpo estava escancarado em vários lugares. Não conseguiram resistir; estavam de novo ali $[\ldots] .^{58}$

Em "O novo advogado" [janeiro/fevereiro 1917], como esquecer, ainda que seu exterior lembre pouco aquela "remota" época (o próprio narrador, entretanto, não esquece de nos lembrar disso!), que estamos diante do antigo cavalo de batalha de Alexandre da Macedônia? É de se supor portanto que Bucéfalo, reza a lenda morto em combate, tenha testemunhado pelos campos de batalha da Ásia algumas das mais idílicas cenas da história mundial (poucos corpos escancarados, muito pouco sangue, enfim).

Em Durante a construção da Muralha da China [março 1917], o sangue também acaba por irromper no "idílico" cenário de "Unidade! Unidade!", passando então a se expor "docemente":

[...] auf allen Wegen Grüße, Wimpel und Fahnen, niemals hatten sie gesehn wie groß und reich und schön und liebenswert ihr Land war, jeder Landsmann war ein Bruder, für den man eine Schutzmauer baute und der mit allem was er hatte und war sein Leben lang dafür dankte, Einheit! Einheit! Brust an Brust, ein Reigen des Volkes, Blut, nicht mehr eingesperrt im kärglichen Kreislauf des Körpers, sondern süß rollend und doch wiederkehrend durch das unendliche China. ${ }^{59}$

Em todos os caminhos, cumprimentos, flâmulas e bandeiras - nunca antes eles haviam visto como sua terra era grande e rica e bela e digna de ser amada. Todo conterrâneo era um irmão para o qual se construía uma muralha protetora e que por isso agradecia, com tudo o que tinha e era, pela vida inteira. Unidade! Unidade! Peito a peito, uma ciranda do povo, o sangue não mais encerrado na estreita circulação do corpo, mas derramando-se docemente e não obstante retornando pela China infindável. ${ }^{60}$

Em "Uma folha antiga" [março 1917]:

Letzthin dachte der Fleischer, er könne sich wenigstens die Mühe des Schlachtens sparen, und brachte am Morgen einen lebendigen Ochsen. Das darf er nicht mehr wiederholen. Ich lag wohl eine Stunde ganz hinten in meiner Werkstatt platt auf dem Boden und alle meine Kleider, Decken und Polster hatte ich über mir aufgehäuft, nur um das Gebrüll des Ochsen nicht zu hören, den von allen Seiten die Nomaden ansprangen, um mit den Zähnen Stücke aus seinem warmen Fleisch zu reißen. Schon lange war es still, ehe ich mich auszugehen getraute; wie Trinker um ein Weinfaß lagen sie müde um die Reste des Ochsen. ${ }^{61}$

\footnotetext{
${ }^{58}$ F. Kafka, "Chacais e árabes", em MR, p. 33-35 (tradução ligeiramente modificada).

${ }^{59}$ F. Kafka, "Oktavheft C" [Beim Bau der chinesischen Mauer], em KKA N1, p. 342 (grifos meus).

${ }^{60}$ F. Kafka, Durante a construção da Muralha da China, em NE, p. 77-78 (tradução modificada).

${ }^{61}$ F. Kafka, "Ein altes Blatt", em $L A$, p. 45-47 (grifos meus).
} 
Não faz muito o açougueiro pensou que podia ao menos se poupar do esforço do abate e uma manhã trouxe um boi vivo. Isso ele não deve mais repetir. Fiquei bem uma hora estendido no fundo da oficina com todas as roupas, cobertas e almofadas empilhadas em cima de mim para não ouvir os mugidos do boi que os nômades atacavam de todos os lados para arrancar com os dentes pedaços de sua carne quente. Quando me atrevi a sair já fazia silêncio há muito tempo; como bêbados em torno de um barril de vinho eles estavam deitados mortos de cansaço em torno dos restos do boi. ${ }^{62}$

\section{Em "Um cruzamento" [março 1917]:}

Ich bin nahezu überzeug, es wüsste sich vor Neid nicht zu fassen, wenn ich inm einmal zeigen würde, wie der Fleischer die jungen Lämmer absticht. Das Messer des Fleischers wäre vielleicht eine Erlösung für dieses Tier.

Estou quase convencido de que ele não iria se conter de inveja, se eu um dia mostrasse a ele como 0 açougueiro degola os jovens cordeiros. A faca do açougueiro talvez fosse para este animal uma libertação. ${ }^{63}$

Em "Um relatório para uma academia" [abril 1917]:

Man schoß; ich war der einzige, der getroffen wurde; ich bekam zwei Schüsse. Einen in die Wange; der war leicht; hinterließ aber eine große ausrasierte rote Narbe [...]. Der zweite Schuß traf mich unterhalb der Hüfte. Er war schwer, er hat es verschuldet, daß ich noch heute ein wenig hinke. ${ }^{64}$

Atiraram; fui o único atingido; eu levei dois tiros. Um na bochecha: esse foi leve, mas deixou uma cicatriz vermelha de pêlos raspados [...]. $\underline{\text { O segundo tiro me }}$ acertou embaixo da anca. Foi grave e a ele se deve o fato de ainda hoje eu mancar um pouco. ${ }^{65}$

No breve espaço de tempo de apenas cinco meses (!), entre o final de novembro de 1916 e o final de abril de 1917, Kafka escreve todos os textos acima. De dentro deste poderoso complexo de imagens que gravitam ao redor do motivo do corpo danificado, ou seja, de um corpo não mais capaz de conter sua própria substância, de um corpo cuja própria substância passa a se derramar sobre o seus estreitos limites, virá também à tona em dois pequenos fragmentos do final de março de 1917 uma outra imagem extraordinária, a saber, a das "páginas danificadas". Não custa assinalar que, neste caso,

\footnotetext{
${ }^{62}$ F. Kafka, "Uma folha antiga", em MR, p. 26.

${ }^{63}$ F. Kafka, "Oktavheft D" ["Eine Kreuzung"], em KKA N1 App, p. 312 (grifos meus). Entenda-se a partir daqui que todos os trechos que estiverem riscados neste trabalho encontram-se riscados no manuscrito kafkiano e por isso, tendo em vista o critério adotado pela Edição Crítica de sua produção, constam apenas no volume suplementar, ou seja, no volume do aparato crítico.

${ }^{64}$ F. Kafka, "Ein Bericht für eine Akademie", em $L A$, p. 152-153 (grifos meus).

${ }^{65}$ F. Kafka, "Um relatório para uma academia", em MR, p. 61 (tradução modificada).
} 
estamos diante de uma imagem também correlata deste motivo central: aqui é o "corpo" da escrita que passa a ser concebido sob o viés da lesão ou do dano; ou seja, a própria escrita como uma espécie de corpo danificado:

Diese (vielleicht allzusehr europäisierende) Übersetzung einiger alter chinesischer Manuscriptblätter stellt uns ein Freund der Aktion zur Verfügung. Es ist oin Bruchstück. Hoffnung, daß die Fortsetzung gefunden werden könnte besteht nicht.

\section{$<\quad>$}

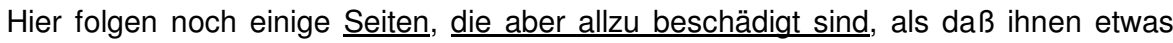
bestimmtes entnommen werden könnte.

Esta tradução (talvez demasiadamente europeizada) de algumas velhas folhas manuscritas chinesas foi colocada à nossa disposição por um amigo da ação. É umfragmento. Esperança de que a continuação possa ser encontrada não existe.

$\begin{array}{ccc}< & > \\ \text { Aqui seguem-se ainda algumas páginas, que porém estão demasiadamente }\end{array}$

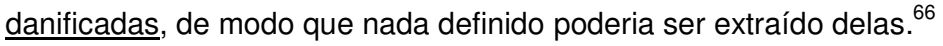

Estes dois pequenos fragmentos - separados por duas espécies de chaves com um longo espaço em branco entre elas - foram redigidos no final de março de 1917 imediatamente após a escrita das narrativas Durante a construção da Muralha da China e "Uma folha antiga [da China]" ${ }^{\text {"67 }}$. O primeiro destes fragmentos, com sua referência explícita às "velhas folhas manuscritas chinesas", esboça uma espécie de narrativa-moldura capaz então de agrupar as duas "narrativas chinesas" recém-escritas e é construído a partir do ponto de vista de um narrador-editor (uma ocorrência única em Kafka!) que, no entanto, recorre a um "nós", ou seja, o mesmo ponto de vista adotado pelas narrativas precedentes ${ }^{68}$ : este editor chama a atenção para o caráter fragmentário do material que tem em mãos e para a ausência de esperança de se encontrar uma continuação. Já o segundo fragmento, construído a partir de um ponto de vista impessoal - o que opera uma quebra com a perspectiva do primeiro fragmento -, pode ser lido, ainda assim, como uma continuação

\footnotetext{
${ }^{66}$ F. Kafka, "Oktavheft C", em KKA N1, p. 361 (grifos meus). Cf. também F. Kafka, "Oxforder Oktavheft 3", em HKKA O3/4, p. 126-127.

${ }^{67} \mathrm{O}$ título original da narrativa "Uma folha antiga", publicado por Kafka no volume Um médico rural, continha a referência à China.

${ }^{68}$ Cf. Durante a construção da Muralha da China (em NE, p. 80 e 84, tradução modificada): "Nós - certamente falo aqui em nome de muitos [...]."; "Tão grande é nosso país que nenhum conto de fada dá conta do seu tamanho, o céu é quase incapaz de cobri-lo." ("Wir - ich rede hier wohl im Namen vieler [...]."; "So groß ist unser Land, kein Märchen reicht an seine Größe, kaum der Himmel umspannt es.") e "Uma folha antiga" (em $M R$, p. 24 e 26): "É como se muita coisa tivesse sido negligenciada na defesa da nossa pátria."; "A nós, artesãos e comerciantes, foi confiada a salvação da pátria [...]." ("Es ist, als wäre viel vernachlässigt worden in der Verteidigung unseres Vaterlandes."; "Uns Handwerkern und Geschäftsleuten ist die Rettung des Vaterlandes anvertraut [...].")
} 
do primeiro; levando-se em conta, no entanto, a especificidade do medium dos cadernos in-oitavo ${ }^{69}$, a hipótese deste fragmento também poder ser lido como anotação solta do próprio escritor não pode ser descartada. Retornaremos a estes dois fragmentos nas considerações finais deste trabalho, mais uma vez no entanto apropriamo-nos do qualificativo "beschädigt" ("danificado"), voltando-o para a própria forma kafkiana. Pois o assumir-se radicalmente como "danificada" é, com efeito, o que está por trás da reviravolta que se opera na produção do escritor a partir deste ponto.

Dito isto, torna-se então necessário abrir um pequeno parêntese com o objetivo de ressaltar uma importante distinção operada por Walter Benjamin, a saber, a diferença entre "Schwelle" (limiar) e "Grenze" (limite/fronteira). Como procuraremos mostrar, trata-se de uma distinção decisiva não apenas para se compreender de maneira mais produtiva uma espécie de obsessão temática do escritor, mas principalmente para se apreender um comportamento próprio da forma kafkiana.

\footnotetext{
${ }^{69}$ Até quase o final de 1916, Kafka tinha por hábito a manutenção de dois cadernos no formato in-quarto (ou seja, cadernos em um formato grande: geralmente de $30 \mathrm{~cm}$ por $25 \mathrm{~cm}$ ): em um deles o escritor concentrava a sua produção literária ao passo que o outro era dedicado à escrita dos diários. A partir de novembro de 1916, Kafka suspenderá a escrita dos diários nos cadernos in-quarto e passará a empregar apenas os chamados cadernos in-oitavo (ou seja, cadernos de pequeno formato: $15 \mathrm{~cm}$ por $10 \mathrm{~cm}$ ), que passam então a concentrar toda a sua escrita: leia-se produção literária, anotações de diários, esboços de cartas, aforismos etc. O uso exclusivo e seqüencial do caderno in-oitavo - ou seja, Kafka utilizará apenas um caderno in-oitavo por vez e apenas abrirá um novo caderno após o anterior ter chegado ao fim - será mantido até o final de julho de 1917; a partir desta data, Kafka voltará a se valer, paralelo ao uso dos cadernos in-oitavo, do caderno in-quarto para a escrita dos diários.
} 


\title{
A perversão do limiar
}

\begin{abstract}
Ritos de passagem - assim se denominam no folclore as cerimônias ligadas à morte, ao nascimento, ao casamento, à puberdade etc. Na vida moderna, estas transições tornaram-se cada vez mais irreconhecíveis e difíceis de vivenciar. Tornamo-nos muito pobres em experiências liminares. O adormecer talvez seja a única delas que nos restou. ( $E$, com isso, também o despertar.) $E$, finalmente, tal qual as variações das figuras do sonho, oscilam também em torno de limiares os altos e baixos da conversação e as mudanças sexuais do amor. "Como agrada ao homem", diz Aragon, "manter-se na soleira da imaginação!" (Paysan de Paris, Paris, 1926, p. 74). Não é apenas dos limiares destas portas fantásticas, mas dos limiares em geral que os amantes, os amigos, adoram sugar as forças. As prostitutas, porém, amam os limiares das portas do sonho. - O limiar [Schwelle] deve ser rigorosamente diferenciado da fronteira [Grenze]. O limiar é uma zona. Mudança, transição, fluxo estão contidos na palavra schwellen (inchar, intumescer), e a etimologia não deve negligenciar estes significados. Por outro lado, é necessário determinar o contexto tectônico e cerimonial imediato que deu à palavra o seu significado. - Morada de sonho $\cdot\left[\mathrm{O} 2^{\mathrm{a}}, 2\right]^{70}$
\end{abstract}

O fragmento acima foi extraído do "caderno temático" ("Konvolut") "Prostituição, jogo" que, por sua vez, integra as Passagens de Walter Benjamin. Como se pode notar, nas últimas linhas deste fragmento, Benjamin defende justamente uma distinção rigorosa entre "Schwelle" (limiar) e "Grenze" (limite/fronteira). No instigante - e infelizmente breve ensaio "Entre a vida e a morte", Jeanne Marie Gagnebin debruçou-se justamente sobre esta distinção operada por Benjamin para em seguida assinalar a aparição de uma "variante cruel" do conceito de "Schwelle" identificada pelo crítico exatamente na produção kafkiana. A seguir, acompanho muito de perto as reflexões desdobradas com pertinência por Gagnebin neste ensaio. Segundo a autora, o conceito de "Grenze" (limite/fronteira) constituiria no âmbito filosófico uma metáfora para designar uma "dupla operação de espírito e de linguagem": "desenhar um traço em redor de algo para the dar uma forma bem definida e, portanto, evitar que esse algo, por assim dizer, se derrame sobre suas bordas em direção a um infinito onipotente (o apeiron de Anaximandro), ou, mais freqüentemente desde Platão, em direção a um infinito informe, vago, um 'mau infinito', diria Hegel. A fronteira contém e mantém algo, evitando seu transbordar, isto é, define seus limites não só como os contornos de um território, mas também como as

\footnotetext{
${ }^{70}$ W. Benjamin, Passagens, p. 525.
} 
limitações do seu domínio."71 Já o conceito de "Schwelle" (limiar) - também proveniente do "domínio de metáforas espaciais que designam operações intelectuais e espirituais"72 assinala um "registro mais amplo, registro do movimento, registro de ultrapassagem, de 'passagens', justamente de transições, em alemão, registro do Übergang. Na arquitetura, o limiar deve preencher justamente a função de transição, isto é, permitir ao andarilho ou também ao morador que possa transitar, sem maior dificuldade, de um lugar determinado a outro, diferente, às vezes oposto. [...] o limiar não faz só separar dois territórios (como a fronteira), mas permite a transição, de duração variável, entre esses dois territórios. Ele pertence à ordem do espaço, mas também, essencialmente, à do tempo."73

A distinção operada por Benjamin, contudo, não contém, e este ponto também é destacado por Gagnebin, apenas um alcance terminológico ou conceitual, mas constitui também uma reflexão histórica mais ampla: afinal, como diz Benjamin, "na vida moderna, estas transições tornam-se cada vez mais irreconhecíveis e difíceis de vivenciar. Tornamo-nos muito pobres em experiências liminares." ${ }^{\text {74 }}$ Haveria portanto na modernidade sob o influxo do capitalismo - que, a seu turno, reduz o tempo a uma seqüência vertiginosa de "momentos iguais sob o véu da novidade (como no fluxo incessante de produção de novas mercadorias)" - uma diminuição radical da "percepção sensorial por ritmos diferenciados de transição"75. Esta escassez de experiências liminares ("Schwellenerfahrungen") acabaria, contudo, por engendrar uma "variante cruel" identificada por Benjamin na produção de Kafka, a saber, a perversão do limiar, estaríamos então diante de uma outra apreensão do conceito de limiar na reflexão deste crítico:

\footnotetext{
${ }^{71}$ Cf. J. M. Gagnebin, "Entre a vida e a morte", em E. Cornelsen et alii (orgs.), Limiares e passagens em Walter Benjamin, p. 13.

72 Ibidem.

${ }^{73}$ Op. cit., p. 13-14. À margem, vale destacar a interessante pesquisa etimológica empreendida por Gagnebin no sentido de explicar a dificuldade do português e do francês em operar com uma distinção clara entre limite (Grenze) e limiar (Schwelle); razão pela qual a tradução deste fragmento benjaminiano se torna tão complicada: "Com efeito, limite, fronteira, Grenze vem do latim limes, limitis, um substantivo masculino, 'caminho que borda um domínio', daí limitar, limitação, delimitação; enquanto limiar, soleira, Schwelle deriva de limen, liminis, um substantivo neutro, seuil, linteau, a viga ou o lintel que sustenta as paredes de uma porta. A semelhança fonética entre limes, limitis e limen, liminis explicaria, segundo os autores do dicionário em questão [A. Ernout e A. Meillet, Dictionnaire étymologique de la langue latine], por que 'nas línguas romanas limitaris foi confundido com liminaris', ou também por que tendemos a usar, por vezes, de maneira sinônima, as palavras 'fronteira', 'limite' e 'limiar', em particular porque todos os termos aludem à separação entre dois domínios do real, muitas vezes opostos. Assim, esquece-se facilmente que o limiar não significa somente a separação, mas também aponta para um lugar e um tempo intermediários e, nesse sentido, indeterminados, que podem, portanto, ter uma extensão variável, mesmo indefinida." (op. cit., p. 14)

${ }^{74}$ W. Benjamin, Passagens, p. 525, grifo meu.

${ }^{75}$ J. M. Gagnebin, "Entre a vida e a morte", em E. Cornelsen et alii (orgs.), Limiares e passagens em Walter Benjamin, p. 15.
} 


\begin{abstract}
A experiência do limiar, da passagem, da transição, as metáforas das portas, dos corredores, dos vestíbulos, tudo isso povoa a obra de Kafka - mas não leva a lugar nenhum. Pior: o limiar parece ter adquirido uma tal espessura que dele não se consegue sair, o que acaba negando sua função.

[...] um limiar inchado, caricato, que não é mais lugar de transição, mas, perversamente, lugar de detenção, zona de estancamento e de exaustão, como se $o$ avesso da mobilidade trepidante da vida moderna fosse um não poder nunca sair do lugar. ${ }^{76}$
\end{abstract}

Dito isso retorno então ao argumento exposto antes deste pequeno parêntese sobre a "perversão do limiar": o que se tem na produção de Kafka a partir do final de 1916 é uma escrita que não apenas sabe de sua condição "danificada" - desde os primeiros textos literários de Kafka, como vimos, esta percepção já está presente - mas que passa a explorar precisamente este estado de coisas. A quase incapacidade de se impor limites, de delimitar com precisão seus próprios contornos, enfim, a impossibilidade de acabamento será radicalmente apropriada e internalizada pela forma kafkiana. $O$ resultado desta estratégia será uma forma que passa então a se configurar agora refletidamente enquanto forma danificada ou, para nos adiantarmos um pouco, enquanto forma que opera no limiar entre o semiacabamento e a semidestruição, conforme os termos de uma anotação do escritor datada do início de 1921 que desdobraremos mais adiante.

Esta ampla e decisiva manobra formal desencadeará, por sua vez, uma série de desdobramentos nos meandros da nova produção. É preciso contudo não perder de vista que apesar dos inúmeros pontos de ruptura com a produção dos dois ciclos anteriores, muitos dos avanços que haviam se operado na forma kafkiana a partir da ruptura de 1912 serão obviamente mantidos pelo escritor neste novo ciclo produtivo, sobretudo a linguagem fria e sóbria, característica do protocolo, uma linguagem que buscava assim se ajustar ao mundo administrado, mas que "na sua exatidão serena e pacífica, na sua distância desapaixonada, [...] se choca violentamente com as experiências muitas vezes

\footnotetext{
76 J. M. Gagnebin, "Entre a vida e a morte", em E. Cornelsen et alii (orgs.), Limiares e passagens em Walter Benjamin, p. 19-20.
} 
horripilantes que comunica"77. Este estilo de protocolo que a partir do final de 1912 se cristaliza em sua produção adquiria contudo mais destaque e se tornava assim mais significativo em vista do foco narrativo que o escritor também passa a explorar de maneira sistemática a partir deste momento, a saber, aquele em terceira pessoa porém projetado a partir do "herói":

[...] conquanto o mundo seja projetado, em essência, a partir do herói, o foco narrativo não é por inteiro idêntico a ele; não é o herói que narra na forma do "eu", mas um narrador encoberto que se refere ao herói através do pronome "ele". ${ }^{78}$

Em face desta dinâmica entre linguagem fria e perspectiva projetada a partir do herói mas não-idêntica a ele, Rosenfeld anotou com perspicácia: por um lado, "essa não-identidade explica [...] a linguagem sóbria e ordenada que talvez fosse menos adequada se partisse de um 'eu' na situação angustiosa do herói”; por outro, "a linguagem fria parece provir do próprio herói: lutando com o poder contrário, ele lhe sucumbe até o âmago do coração, adotando-lhe o caráter e passando a falar a sintaxe alienada do protocolo"79. Como veremos, a manutenção do protocolo, apesar da avalanche de narrativas em $1^{\text {a }}$ pessoa (assentadas na identidade entre narrador e herói) que irrompe na produção kafkiana a partir do final de 1916 (esta exploração da narrativa em 1aㅡ pessoa empreendida pelo escritor a partir desta data será aliás um traço distintivo desta nova produção em relação aos últimos dois ciclos produtivos), parece fazer com que o fiel da balança penda para a segunda hipótese formulada por Rosenfeld. Pense-se para tanto em um caso extremo como o do narrador-construtor em $\underline{A \text { construção }}$ [novembro/dezembro 1923]: mesmo na mais extrema angústia (e insuportavelmente prolongada até a interrupção da narrativa), este eu-narrador ainda se mostra capaz de expressar-se em linguagem sóbria, caracterizada mesmo por uma lógica implacável.

\footnotetext{
${ }_{77}$ A. Rosenfeld, "Kafka e kafkianos, Texto/Contexto I, p. 232-233.

${ }^{78}$ Op. cit., p. 234. Com exceção de apenas duas narrativas em $1^{\text {a }}$ pessoa (Recordações da estrada de ferro de Kalda [agosto 1914] e O mestre-escola da aldeia [dezembro 1914]), todos os demais textos escritos entre 1912 e 1915 serão narrados em $3^{\text {a }}$ pessoa (a partir porém da perspectiva do "herói"): O veredicto [setembro 1912], O desaparecido [1912-1914], A metamorfose [novembro 1912], O processo [1914-1915], Na colônia penal [outubro 1914], Blumfeld, um solteiro de meia-idade [janeiro/fevereiro 1915]. À exploração sistemática da $3^{\text {a }}$ pessoa entre 1912 e 1915, segue-se o predomínio da narração em 1ª pessoa entre 1916 e 1921; sendo que com a produção que se inicia em janeiro de 1922, Kafka passa então a um uso relativamente equilibrado destas duas perspectivas: nesse sentido, vale lembrar que o romance $O$ castelo [janeiro/agosto 1922] foi iniciado por Kafka, curiosamente, em 1a pessoa, sendo pouco tempo depois reescrito em $3^{\underline{a}}$; convém ainda destacar que o último livro organizado em vida pelo escritor Um artista da fome compõe-se sintomaticamente de duas narrativas em $3^{\text {a }}$ pessoa ("Primeira dor" e "Um artista da fome") e de outras duas em 1" ("Uma mulher pequena" e "Josefina, a cantora"), sendo que estas duas perspectivas alternam-se no interior do volume, ou seja, primeira e terceira narrativas em $3^{\underline{a}}$ pessoa e segunda e quarta narrativas em $1^{\text {a }}$.

${ }^{79}$ A. Rosenfeld, "Kafka e kafkianos, Texto/Contexto I, p. 234.
} 
Apesar da permanência de várias características da produção anterior a 1916, não há como ignorar os pontos de ruptura que se fazem sentir neste novo ciclo criativo. Em primeiro lugar, e de um ângulo mais externo, nota-se de pronto uma forte inclinação para o que o próprio escritor chamará de "prosa pequena" ("kleine Prosa") ${ }^{80}$. Diante disso não custa assinalar que de 1912 a 1915, Kafka havia se empenhado de modo obsessivo na tarefa de escrita e publicação de um livro extenso; o crítico Unseld chega mesmo a se referir a um "complexo da ausência de um livro extenso" ("Komplex des fehlenden großen Buches") $)^{81}$. Nesse sentido, convém reparar que os dois ciclos produtivos compreendidos por este período (1912-1915) haviam se desdobrado tendo por referência cada qual a escrita de um romance e chegado ao fim com o abandono do respectivo romance $(O$ desaparecido estaria portanto para o ciclo de setembro de 1912 a janeiro de 1913 como $O$ processo para o ciclo de agosto de 1914 a janeiro de 1915); sendo que o malogro de cada um destes romances desencadearia então um longo período de esterilidade criativa: no caso de $O$ desaparecido, a crise se arrastaria por um ano e meio e no caso de $O$ processo por quase dois anos! Que o escritor, contudo, tenha retomado durante a escrita de $O$ processo também o trabalho em $O$ desaparecido acaba por conferir a este último ciclo uma aura, sem dúvida, mais dramática. Como se sabe, em fins de agosto de 1914, ou seja, poucos dias após ter iniciado $O$ processo, Kafka retoma o trabalho em $O$ desaparecido: neste momento Kafka redigirá então uma breve continuação para o capítulo "Levante! Levante! - gritou Robinson..." e também o fragmento "Partida de Brunelda". Além disso, em outubro deste mesmo ano, ao tirar duas semanas de férias com o objetivo principal de avançar a escrita de $O$ processo, Kafka deixará este romance de lado e redigirá, além da novela $N a$ colônia penal, também o fragmento "O teatro natural de Oklahoma", erroneamente tomado por Max Brod como capítulo final de $O$ desaparecido. Assinale-se ainda que a retomada do trabalho em um romance abandonado é algo absolutamente isolado na carreira do escritor: ao abandonar $O$ processo em janeiro de 1915 e O castelo em agosto de 1922 Kafka não mais voltará a nenhum deles.

Diante disso não parece despropósito imaginar que o estancamento deste último ciclo tenha sido sentido pelo escritor como um golpe ainda mais pesado, pois se tratava de fato de um "duplo fracasso": Kafka não apenas não havia conseguido fechar $O$ desaparecido como também $O$ processo restava inacabado. Este pano de fundo torna também mais compreensível a grave e duradoura crise produtiva que então se seguiu e que será superada apenas no final de 1916, com um escritor desde o começo avesso a

\footnotetext{
${ }^{80}$ Cf. F. Kafka, Briefe 1902-1924, p. 157 (carta de 27.07.1917 ao editor Kurt Wolff).
}

81 J. Unseld, Franz Kafka: ein Schriftstellerleben, p. 130. 
incursões narrativas mais extensas. Outro projeto de maior fôlego como estes tomará corpo apenas no final de janeiro de 1922 - portanto, sete anos mais tarde! - com a escrita de $O$ castelo, porém em um contexto já muito distante daquele dos primeiros romances; aqui o romance já se sabe inviabilizado desde o princípio ou, nas palavras do próprio escritor, "inacabado, inacabável, impublicável" ("unvollendet, unvollendbar, unpublizierbar") ${ }^{82}$ e isso muda tudo.

Outro testemunho evidente desta obstinação do escritor neste período (de 1912 a 1915) por um livro extenso são seus dois projetos frustrados de um "livro de novelas" ("Novellenbuch") que vêm à luz sintomaticamente na esteira dos fracassos dos dois primeiros romances: ao malogro de $O$ desaparecido em janeiro de 1913 segue-se já em abril deste mesmo ano o projeto Os filhos (Die Söhne) ${ }^{83}$, que então reuniria em um grande volume as novelas do ano anterior - $O$ foguista, $O$ veredicto e $A$ metamorfose; ao abandono de $O$ processo em janeiro de 1915 seguirá em outubro do mesmo ano o projeto Punições (Strafen) ${ }^{84}$, reunindo desta vez $O$ veredicto, A metamorfose e Na colônia penal. A propósito, os próprios títulos destes dois projetos - Os filhos e Punições - assinalam o alargamento do horizonte de sua produção a partir de agosto de 1914 e também quão consciente o escritor estava dele, passando então de um núcleo mais estreito (família) para estruturas mais gerais e amplas (sociedade). Como bem assinala O. Jahraus: "No centro agora estão não mais estruturas familiares de poder, mas sim estruturas gerais que se referem à relação entre indivíduo, sociedade e as instâncias de integração social." ${ }^{85}$

Isso posto, é hora de nos embrenharmos ainda mais nos meandros desta nova produção, pois precisamente aí inúmeras outras alterações significativas no período períodos se deixam notar. O crítico Anatol Rosenfeld caracterizou a produção kafkiana, em termos abrangentes, como o "resultado de um processo de redução, acentuação unilateral, deformação; processo que [...] distorce, abala ou até elimina as categorias fundamentais - tempo, espaço, causalidade, substância -, assim como os níveis ontológicos - coisa, planta, animal, homem - que moldam a nossa experiência corriqueira." ${ }^{86}$ Se referirmos o comentário do crítico aos diferentes momentos da produção kafkiana, ou seja, aos diferentes ciclos produtivos deste escritor, ele poderá se revelar

\footnotetext{
${ }^{82}$ F. Kafka apud J. Unseld, Franz Kafka: Ein Schriftstellerleben, p. 205 e p. 287. Cf. ainda neste contexto a carta de Kafka a Brod datada de 20.07.1922:

[Das Schloss] ist zum Geschrieben-, nicht zum Gelesenwerden. (F. Kafka, Briefe 1902-1924, p. 396.)

[O castelo] é para se escrito não para ser lido.

${ }^{83}$ Cf. F. Kafka, Briefe 1902-1924, p. 115 e 116 (cartas de 04.04 .1913 e 11.04 .1913 ao editor Kurt Wolff).

${ }^{84}$ Cf. op. cit., p. 133-134 (carta de 15.10.1915 à Editora Kurt Wolff).

${ }^{85}$ O. Jahraus, Kafka: Leben, Schreiben, Machtapparate, p. 295.

${ }^{86}$ A. Rosenfeld, "Kafka e kafkianos", em Texto/Contexto I, p. 230.
} 
ainda mais interessante. Assim sendo, cumpre ressaltar que os abalos mais profundos e decisivos, senão mesmo a supressão completa, das categorias e dos níveis ontológicos referidos por Rosenfeld operam-se precisamente com a produção que se inicia no final de 1916. À margem, assinale-se que Walter Benjamin foi, sem dúvida, o primeiro crítico a chamar atenção para o caráter deformado ou desfigurado do mundo de Kafka ("[...] die präziste Entstellung, die so bezeichnend für Kafkas Welt ist [...]." ${ }^{\wedge 7}$ ); cumpre porém reconhecer, e este é um dos pontos que defendo em meu trabalho, que a referida deformação não se distribui de modo homogêneo ou uniforme pelo conjunto da produção kafkiana.

${ }^{87}$ W. Benjamin, “Franz Kafka: Beim Bau der chinesischen Mauer” [1931], em Benjamin über Kafka, p. 44. 


\section{A radicalização da deformação ou o mundo como emaranhado in-finito}

A partir deste novo ciclo produtivo, não há como negar que as coordenadas espaciais e temporais passam a ser radicalmente borradas pelo escritor, tornando-se com isso quase impossíveis de serem apreendidas. Isto se deixa notar com perfeição em uma narrativa central deste período, a saber, um "Um médico rural" [dezembro 1916/janeiro 1917] na qual a distância espaçotemporal que separa a casa do médico da do jovem doente - a princípio, fixa: dez milhas - passa sintomaticamente a oscilar: ao passo que a viagem de ida se estende por um instante apenas:

Ich war in großer Verlegenheit: eine dringende Reise stand mir bevor; ein Schwerkranker wartete auf mich in einem zehn Meilen entfernten Dorfe; starkes Schneegestöber füllte den weiten Raum zwischen mir und ihm [...]. [...].Aber auch das nur einen Augenblick, denn, als öffne sich unmittelbar vor meinem Hoftor der Hof meines Kranken, bin ich schon dort [...]. ${ }^{88}$

Eu estava num grande aperto: tinha diante de mim uma viagem urgente; um doente grave me esperava numa aldeia a dez milhas de distância; forte nevasca enchia o espaço entre mim e ele [...]. [...]. Mas por um instante apenas, pois como se diante do portão do pátio se abrisse o pátio do meu doente, já estou lá [...]. ${ }^{89}$

a volta se revela infinita:

[...] beeilten sich die Pferde wie auf der Herfahrt, sprang ich ja gewissermaßen aus diesem Bett in meines. [...]. Ich schwang mich aufs Pferd. Die Riemen lose schleifend, ein Pferd kaum mit dem andern verbunden, der Wagen irrend hinterher, der Pelz als letzter im Schnee. "Munter! " sagte ich, aber munter ging's nicht; langsam wie alte Männer zogen wir durch die Schneewüste [...]. [...]. Niemals komme ich so nach Hause [...]. Nackt, dem Froste dieses unglückseligsten Zeitalters ausgesetzt, mit irdischem Wagen, unirdischen Pferden, treibe ich mich alter Mann umher. ${ }^{90}$

[...] se os cavalos se apressassem como na viagem de vinda, eu de certo modo saltava desta cama para a minha. [...]. Subi de um salto no cavalo. As rédeas deslizando soltas, um cavalo quase desligado do outro, o carro rodando atrás aos trancos, por último a pele arrastando na neve. - Em frente! - eu disse, mas eles não foram a galope. Devagar como homens velhos cruzamos o deserto de neve [...]. [...]. Assim nunca vou chegar em casa [...]. Nu, exposto à geada desta época

\footnotetext{
${ }^{88}$ F. Kafka, "Ein Landarzt", em LA, p. 6-14 (grifos meus).

${ }^{89}$ F. Kafka, "Um médico rural", em $M R$, p. 13-15.

${ }^{90}$ F. Kafka, "Ein Landarzt", em LA, p. 31-33 (grifos meus).
} 
desafortunada, com um carro terrestre e cavalos não-terrenos, vou - um velho vagando. $^{91}$

Diante disso, também não deve causar espanto que o mais curto dos percursos - como aquele que separa o jovem cavaleiro da aldeia mais próxima em "A próxima aldeia" [dezembro 1916/janeiro 1917] - acabe se mostrando tão impossível de ser percorrido quanto "a mais remota distância" ("die fernste Ferne"92), por exemplo, aquela que separa o mensageiro - de posse da mensagem do imperador moribundo - do súdito em "Uma mensagem imperial" [março 1917]. Aliás, não por acaso, Kafka haveria de posicionar estas duas narrativas lado a lado no miolo do volume Um médico rural. $\mathrm{E}$ assim, sem muito alarde, medidas "diferentes" passam estranhamente a coincidir ao passo que grandezas "equivalentes" não mais se conformam. Ao final resta portanto um mundo da desmedida ${ }^{93}$, um mundo no qual espaço e tempo escapam a qualquer possibilidade de delimitação, de contenção, de previsão:

Ein alltäglicher Vorfall; sein Ertragen ein alltäglicher Heroismus: A. hat mit B. aus dem Nachbardorf $\mathrm{H}$ ein wichtiges Geschäft abzuschließen. Er geht zur Vorbesprechung nach $\mathrm{H}$, legt den Hin- und Herweg in je zehn Minuten zurück und rühmt sich zuhause dieser besonderen Schnelligkeit. Am nächsten Tag geht er wieder nach $\mathrm{H}$, diesmal zum endgültigen Geschäftsabschluß; da dieser voraussichtlich mehrere Stunden erfordern wird, geht A. schon frühmorgens aus; trotzdem aber alle Nebenumstände, wenigstens nach A.'s Meinung, völlig die gleichen sind wie am Vortag braucht er diesmal zum Weg nach $\mathrm{H}$ zehn Stunden. Als er dort ermüdet abends ankommt, sagt man ihm, daß B. ärgerlich wegen A's Ausbleiben vor einer halben Stunde zu A. in sein Dorf hinüber gegangen sei; sie hätten einander eigentlich treffen müssen. Man rät $A$. zu warten, $B$. müsse ja gleich zurückkommen. A. aber, in Angst wegen des Geschäftes, macht sich sofort auf und eilt nachhause. Diesmal legt er den Weg, ohne besonders darauf zu achten, geradezu in einem Augenblick zurück. Zuhause erfährt er, B. sei doch schon gleich früh gekommen, noch vor dem Weggang A.'s, ja er habe A. im Haustor getroffen, ihn an das Geschäft erinnert, aber A. habe gesagt, er hätte jetzt keine Zeit, er müsse jetzt eiligst fort. Trotz dieses unverständlichen Verhaltens A's sei aber B. doch hier geblieben

\footnotetext{
${ }^{91}$ F. Kafka, "Um médico rural”, em MR, p. 20-21 (tradução ligeiramente modificada).

${ }^{92}$ F. Kafka, "Eine kaiserliche Botschaft", em $L A$, p. 90.

${ }^{93}$ Um mundo, enfim, que não parecia estar muito distante - ao menos aos olhos do escritor - de sua própria realidade histórica: cf., a propósito, o início da carta ao editor Kurt Wolff datada de 11.10.1916, ou seja, escrita pouco mais de um mês antes do início deste novo ciclo produtivo:
}

Sehr geehrter Herr Kurt Wolff! Zunächst erlaube ich mir Sie herzlichst wieder einmal in unserer Nähe zu begrüßen, trotzdem jetzt allerdings Ferne und Nähe nicht sehr unterschieden sind.

(F. Kafka, Briefe 1902-1924, p. 150).

Prezado Sr. Kurt Wolff! Primeiramente eu me permito saudá-lo muito cordialmente outra vez em nossa proximidade, ainda que agora, no entanto, distância e proximidade não sejam muito diferentes.

Lembre-se que nesta mesma carta (ao editor que retornava a Leipzig após servir dois anos como soldado no front ocidental) Kafka irá assinalar em seguida a congruência entre o "caráter penoso" de Na colônia penal, novela que Wolff recusava-se então a publicar, e o "caráter penoso" de seu próprio tempo. 
um auf A. zu warten. Er habe zwar schon oft nachgefragt ob A. zurückgekommen sei, befinde sich aber noch immer oben in A.'s Zimmer. Glücklich darüber, B. jetzt noch sprechen und inm alles erklären zu können läuft A. die Treppe hinauf. Schon ist er fast oben, da stolpert er, erleidet eine Sehnenzerrung und fast ohnmächtig vor Schmerz, unfähig sogar zu schreien, nur winselnd im Dunkel, hört und sieht er, wie B., undeutlich ob in großer Ferne oder knapp neben ihm, wütend die Treppe hinunterstampft und endgültig verschwindet. ${ }^{94}$

Um incidente cotidiano; suportá-lo, um heroísmo cotidiano: A. precisa fechar com B., da aldeia vizinha $\mathrm{H}$, um importante negócio. Ele vai a $\mathrm{H}$ para uma conversa prévia, percorre o caminho de ida e o de volta em dez minutos cada, e em casa se gaba dessa particular rapidez. No dia seguinte vai de novo a $\mathrm{H}$, desta vez para o fechamento definitivo do negócio; tendo em vista que este exigirá, segundo as previsões, várias horas, A. parte de manhã bem cedo; mas embora todas as circunstâncias - pelo menos na opinião de A. sejam exatamente as mesmas do dia anterior, dessa vez ele precisa de dez horas para fazer o caminho até $H$. Quando chega lá à noite, exausto, dizem-lhe que B., irritado com o não-comparecimento de $A$, tinha ido fazia meia hora para a aldeia de $A$. e que na verdade deveriam ter-se encontrado no caminho. Aconselham $A$. a esperar, pois $B$. teria de voltar logo. Mas A., angustiado com a realização do negócio, parte imediatamente e vai às pressas para casa. Dessa vez, sem prestar atenção especial nisso, percorre o caminho em não mais que um instante. Em casa fica sabendo que de fato $B$. tinha chegado muito cedo - ainda antes da partida de A.; na realidade tinha encontrado A. na porta de casa, o havia lembrado do negócio, mas $A$. dissera que agora não tinha tempo, que precisava partir a toda. Apesar do comportamento incompreensível de A., no entanto, B. ficara ali esperando $A$. Já havia perguntado várias vezes se $A$. ainda não tinha voltado, mas ainda estava lá em cima, no quarto de A. Feliz com o fato de agora poder falar com B. e de poder explicar-lhe tudo, A. sobe correndo a escada. Já está quase no alto quando tropeça, distende um tendão e, praticamente desmaiado de dor, incapaz até de gritar, apenas gemendo no escuro, ele ouve e vê como B. - impossível distinguir se a grande distância ou bem ao seu lado - desce a escada batendo os pés, furioso, e desaparece para sempre. ${ }^{95}$

Datado de outubro de 1917 e contido no "Caderno in-oitavo 7", este fragmento foi intitulado por Max Brod de "Uma confusão cotidiana" ("Eine alltägliche Verwirrung"). O título inventado por Brod certamente não é dos mais infelizes; o problema maior neste caso está no fato dele ter acrescentado o substantivo "confusão" ("Verwirrung") ao corpo do texto kafkiano e retirado aquele que originalmente constava no manuscrito, a saber "heroísmo" ("Heroismus"). Para que se possa ter uma idéia das modificações operadas por Brod, em contraste com a versão original transcrita acima, cito a seguir o início da sua

\footnotetext{
${ }^{94}$ F. Kafka, "Oktavheft G" ["Eine alltägliche Verwirrung"], em KKA N2, p. 35-36 (grifo meu).

${ }^{95}$ F. Kafka, "Uma confusão cotidiana”, em NE, p. 101-102 (tradução modificada). Pelo fato de Modesto Carone ter utilizado em sua tradução a edição de Max Brod, precisei operar obviamente alterações substantivas em sua tradução.
} 
edição do fragmento (repare ainda no corte incompreensível do substantivo "Nachbardorf"/“aldeia vizinha"): "Ein alltäglicher Vorfall: sein Ertragen eine alltägliche Verwirrung. A hat mit B aus $\mathrm{H}$ ein wichtiges Geschäft abzuschließen."96

Paralelo a estas amplas deformações espaciais e temporais ${ }^{97}$, passamos também a assistir a uma assombrosa invasão de seres de contornos mal definidos, ou seja, de seres cujos limites ("Grenzen") também se mostram comprometidos. Como veremos, estes novos personagens não se encaixam, em absoluto, em um ou outro daqueles níveis ontológicos - homem, coisa, animal, planta -, mas transitam entre eles; nesse sentido, poderíamos então falar com efeito de seres híbridos. Estes novos seres, por sua vez, não apenas entram em cena em primeiro plano, mas também recorrem inúmeras vezes à palavra, quando não se tornam, até mesmo, os próprios narradores ${ }^{98}$. Limitando-nos aqui, porém, aos seres híbridos "fabricados" entre o final de novembro de 1916 e o final de abril

${ }^{96}$ F. Kafka, "Eine alltägliche Verwirrung", em Hochzeitvorbereitungen auf dem Lande (org. por Max Brod), p. 55.

${ }^{97}$ Cf. ainda outros exemplos de deformação, por exemplo, em "Chacais e árabes" [janeiro/fevereiro 1917]:

[...] das Klagegeheul eines Schakals in der Ferne; ich saß wieder aufrecht. Und was so weit gewesen war, war plötzlich nah. (F. Kafka, "Schakale und Araber", em $L A$, p. 58, grifo meu.)

[...] o uivo lamentoso de um chacal à distância; sentei-me outra vez. E o que estivera tão longe estava de repente perto." ("Chacais e árabes", em MR, p. 30.)

Em Durante a construção da Muralha da China [março 1917]:

Ich stamme aus dem südöstlichen China. Kein Nordvolk kann uns dort bedrohn. [...]. [...] gesehen haben wir sie nicht, und bleiben wir in unserm Dorfe, werden wir sie niemals sehn, selbst wenn sie auf ihren wilden Pferden geradeaus zu uns hetzen und jagen; zu groß ist das Land und läßt sie nicht zu uns, in die leere Luft werden sie sich verrennen. ("Oktavheft C" [Beim Bau der chinesischen Mauer], em KKA N1, p. 347.)

Sou natural do sudeste da China. Lá nenhum povo do norte pode nos ameaçar. [...]. Não os vimos nunca e se permanecermos em nossa aldeia nunca os veremos, mesmo que eles se lancem em linha reta à nossa caça, montados nos seus cavalos selvagens - o país é grande demais e não os deixa chegar até nós: cavalgando, eles irão se perder no ar vazio. ([...]."(F. Kafka, Durante a construção da Muralha da china, em NE, p. 81-82.)

So groß ist unser Land, kein Märchen reicht an seine Größe, kaum der Himmel umspannt es. ("Oktavheft C" [Beim Bau der chinesischen Mauer], em KKA N1, p. 350.)

Nosso país é tão grande que nenhuma lenda dá conta do seu tamanho, o céu é quase incapaz de cobri-lo [...].

(F. Kafka, Durante a construção da Muralha da china, em NE, p. 84.)

ou ainda (e este último exemplo mostra até onde pode chegar a "confusão" temporal instaurada):

Längst verstorbene Kaiser werden in unseren Dörfern auf den Tron gesetzt [...]. Schlachten unserer ältesten Geschichte werden jetzt erst geschlagen [...].

(F. Kafka, "Oktavheft C" [Beim Bau der chinesischen Mauer], em KKA N1, p. 352-353.)

Imperadores mortos há muito tempo são entronizados em nossa aldeia [...]. Batalhas da nossa história mais remota só agora são travadas [...]. (F. Kafka, Durante a construção da Muralha da china, em NE, p. 87)

98 No âmbito dos cadernos in-oitavo [novembro de 1916 a maio de 1918] encontramos, a rigor, dois narradores híbridos: a ponte-homem de "A ponte" [janeiro/fevereiro 1917] e o macaco-homem Pedro Vermelho de "Um relatório para uma academia" [abril 1917]; mais adiante, entrarão em cena vários outros: o narrador-cachorro de "Investigações de um cão" [maio 1922], o narrador-animal de $\underline{A}$ construção [novembro/dezembro 1923] e ainda o narrador-camundongo de "Josefina, a cantora ou o povo dos camundongos" [março 1924]. 
de 1917, ou seja, durante o primeiro momento do ciclo produtivo de 1916-1918, poderíamos mencionar: o cavalo-advogado com cabeça de boi "Dr. Bucéfalo",99, ex-cavalo de batalha de Alexandre, o Grande em "O novo advogado" [janeiro/fevereiro 1917] ${ }^{100}$; os "cavalos não-terrenos" ("unirdische Pferde"101) que emergem da pocilga ${ }^{102}$, seguindo, aliás, o exemplo do próprio cavalariço, ou melhor, do servo-cavalo ${ }^{103} \mathrm{em}$ "Um médico

\footnotetext{
99 Do grego Boukephálas, -a: "cabeça de boi". Do latim Bucephalus,-i: "Bucéfalo, cavalo de Alexandre Magno, assim designado em função de sua cabeça ser semelhante à de um boi" (Dicionário Houaiss); "Bucéfalo, nome do cavalo de Alexandre. Alexandre deu-lhe funerais magníficos, às margens do Hidaspo, e fundou junto ao túmulo do animal uma cidade, Bucéfala [cf. Plínio, o Velho, História natural, 8, 154]" (Ernesto Faria, Dicionário Latino-Português, p. 144).

${ }^{100}$ Esta pequena narrativa, a propósito, foi escolhida por Kafka para ser nada menos que o pórtico da coletânea Um médico rural.

${ }^{101}$ Cf. F. Kafka, "Ein Landarzt", em LA, p. 33.

${ }^{102}$ Não por acaso, a esquisita procedência destes cavalos é sublinhado com ênfase pelo narrador:

Was tue ich hier in diesem endlosen Winter! Mein Pferd ist verendet, und da ist niemand im Dorf, der mir seines leiht. Aus dem Schweinstall muß ich mein Gespann ziehen; wären es nicht zufällig Pferde, müßte ich mit Säuen fahren. So ist es. ("Ein Landarzt", em $L A$, p. 20)

O que eu estou fazendo aqui neste inverno interminável? Meu cavalo morreu e na aldeia não há ninguém que me empreste o seu. Preciso tirar minha parelha da pocilga; se por acaso não fossem cavalos eu teria de viajar puxado por porcas. Assim é. ("Um médico rural", em MR, p. 17).
}

A também curiosa comparação traçada pelo narrador destes "cavalos não-terrenos" a camelos não deve ser ignorada:

[...] zwei Pferde, mächtige flankenstarke Tiere schoben sich hintereinander, die Beine eng am Leib, die wohlgeformten Köpfe wie Kamele senkend [...]. (“Ein Landarzt”, em LA, p. 10)

[...] dois cavalos, possantes animais de flancos fortes, as pernas bem coladas ao corpo, baixando as cabeças bem formadas como a de camelos [...]. ("Um médico rural", em MR, p. 14, tradução ligeiramente modificada).

Resumindo: cavalos não-terrenos com cabeças de camelos emergindo do curral dos porcos! Em vista ainda do quadro de um inverno enfaticamente descrito como rigoroso e infinito, poder-se-ia sublinhar a dissonância que se instaura quando da comparação destes cavalos a camelos (ou seja, animais, por definição, adaptados ao deserto); esta incongruência será ainda reforçada mais uma vez ao final do texto (o que portanto descarta a gratuidade da aproximação):

[...] langsam wie alte Männer zogen wir durch die Schneewüste [...]. (“Ein Landarzt”, em LA, p.31-32)

Devagar como homens velhos cruzamos o deserto de neve [...].

(“Um médico rural", em MR, p. 21, tradução ligeiramente modificada)

103 O termo empregado por Kafka é "Pferdeknecht" (um termo, portanto, que combina os substantivos "Knecht"/"servo" e "Pferd"/"cavalo"); Modesto Carone traduziu-o com propriedade como "cavalariço" (portanto, o "indivíduo que cuida de animais em cavalarias ou coudelarias; palafreneiro, estribeiro"). Em vista, porém, da "cavalização" da figura operada pelo texto (como se o escritor tomasse o termo "Pferdeknecht" ao pé da letra), é de se perguntar seriamente se neste caso a tradução mais apropriada não seria mesmo "servo-cavalo". Para tanto, basta reparar em sua triunfal entrada em cena (que, a rigor, antecede a dos dois cavalos nãoterrenos) ao emergir da pocilga:

Ein Mann, zusammengekauert in dem niedrigen Verschlag, zeigte sein offenes blauäugiges Gesicht. 'Soll ich anspannen?' fragte er, auf allen Vieren hervorkriechend. ("Ein Landarzt", em LA, p. 9)

Um homem acocorado no cômodo baixo mostrou o rosto aberto e de olhos azuis. - Devo atrelar? - perguntou, rastejando de quatro para fora. ("Um médico rural", em MR, p. 14).

Diante disso, não parece despropósito afirmar que da pocilga em "O médico rural" não emergem dois, mas três cavalos! Não custa assinalar ainda a sintomática fala do médico ao servo-cavalo, após este morder violentamente o rosto de sua criada:

"Du Vieh", schreie ich wütend, "willst du die Peitsche?" ("Ein Landarzt”, em LA, p. 11) 
rural" [dezembro 1916/janeiro 1917]; a ponte-homem ${ }^{104}$ em "A ponte" [janeiro 1917]; a pomba-galinha" ${ }^{105}$ em "O caçador Gracchus" [janeiro/fevereiro e abril de 1917]; o baldecavalo $^{106} \mathrm{em}$ "O cavaleiro do balde" [janeiro/fevereiro 1917]; os nômades-gafanhotos ${ }^{107}$

"Animal!", grito furioso, "você quer o chicote?" (“Um médico rural”, em MR, p. 14).

A propósito, a polidez desta fala coloca também em suspeição a figura do caridoso e civilizado médico (compare, por exemplo, "Schlecht bezahlt, bin ich doch freigebig und hilfsbereit gegenüber den Armen." ("Ein Landarzt”, em $L A$, p. 19, grifo meu)/"Mal pago, sou no entanto generoso e solícito em relação aos pobres" ("Um médico rural", em MR, p. 17) com "Mein Pelz hängt hinten am Wagen, ich kann ihn aber nicht erreichen, und keiner aus dem beweglichen Gesindel der Patienten rührt den Finger." ("Ein Landarzt”, em LA, p. 33, grifo meu)/"Meu casaco de pele pende atrás da carroça, mas não posso alcançá-lo e ninguém na móvel canalha dos pacientes mexe um dedo." ("Um médico rural”, em MR, p. 21); ou seja, mesmo a figura do, a princípio, insuspeito médico não sai daqui sem chumbo.

${ }^{104}$ Cf. F. Kafka, "Oktavheft B" ["Die Brücke”], em KKA N1, p. 304-305 (grifos meus):

Ich war steif und kalt, ich war eine Brücke, über einem Abgrund lag ich, diesseits waren die Fußspitzen, jenseits die

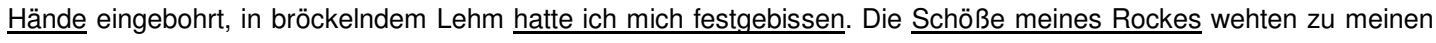
Seiten. [...]. [...] [er] ordnete sie [die Eisenspitze seines Stockes] auf mir, in mein buschiges Haar [...]. [...] sprang er mit beiden Füßen mir mitten auf den Leib. Ich erschauerte in wildem Schmerz, gänzlich unwissend.

Eu estava rígido e frio, eu era uma ponte, estendido sobre o abismo. As pontas dos pés cravadas deste lado, do outro as mãos, eu me prendia firme com os dentes na argila quebradiça. As abas do meu casaco flutuavam pelos meu lados. [...]. Passou a ponta [da bengala] por meu cabelo cerrado [...]. [...]. [...] ele saltou com os dois pés sobre o meio do meu corpo. Estremeci numa dor atroz, sem compreender nada.

("A ponte", em NE, p. 64-65, tradução ligeiramente modificada).

${ }^{105}$ Cf. F. Kafka, "Oktavheft B” ["Der Jäger Gracchus”], em KKA N1, p. 308 (grifo meu):

Es war wirklich eine Taube, aber groß wie ein Hahn. Sie flog zu meinem Ohr und sagte: "Morgen kommt der tote Jäger Gracchus, empfange inn im Namen der Stadt.

Era de fato uma pomba, mas grande como uma galinha. Voou até o meu ouvido e disse: "Amanhã chega o caçador morto Gracchus, receba-o em nome da cidade." ("O caçador Gracchus", em NE, p. 69).

A propósito, a singularidade do protagonista Gracchus não repousa apenas no problemático fato de ser um morto-vivo (questão esta que iremos explorar um pouco mais adiante): convém reparar aqui em seu sugestivo nome "Gracchus" (derivado do latim graculus e do italiano gracchio, ou seja, "gralha") e também em sua sintomática fala (em trecho riscado por Kafka no manuscrito):

[...] aus dem Jäger ist ein Schmetterling geworden. Lachen Sie nicht. (F. Kafka, "Oktavheft B" ["Der Jäger Gracchus"], em KKA N1 App, p. 272)

O caçador tornou-se uma borboleta. Não ria. ("O caçador Gracchus", em NE, p. 70).

${ }^{106}$ Cf. F. Kafka, “Oktavheft B” [“Der Kübelreiter”], em KKA N1, p. 316 (grifo meu):

Alle Vorzüge eines guten Reittieres hat mein Kübel, Widerstandskraft hat er nicht, zu leicht ist er, eine Frauenschürze jagt inm die Beine vom Boden.

Meu balde tem todas as qualidades de uma boa cavalgadura, mas não resistência; ele é leve demais; um avental de mulher tira-lhe as pernas do chão.

(“O cavaleiro do balde", em M. Carone, Lição de Kafka, p. 10, tradução modificada).

Também no contexto de um inverno medonho ("Ungeheuer ist die Kälte [...]."), só que desta vez numa paisagem urbana, convém assinalar a comparação deste balde-cavalo, a exemplo dos cavalos não-terrenos em "Um médico rural", a um camelo:

Als Kübelreiter, die Hand oben am Griff, dem einfachsten Zaumzeug, drehe ich mich beschwerlich die Treppe hinab; unten aber steigt mein Kübel auf, prächtig, prächtig; Kamele, niedrig am Boden hingelagert, steigen, sich schüttelnd unter dem Stock des Führers, nicht schöner auf.

(F. Kafka, "Oktavheft B" [“Der Kübelreiter”], em KKA N1, p. 314.)

Como cavaleiro do balde, ao alto a mão na alça - a mais simples da rédeas -, volto-me com dificuldade e desço a escada; mas embaixo meu balde sobe soberbo, soberbo: camelos agachados no solo não se levantam tão belos estremecendo sob o bastão do cameleiro. ("O cavaleiro do balde", em M. Carone, Lição de Kafka, p. 8)

107 Cf. "Oktavheft C" [Beim Bau der chinesischen Mauer], em KKA N1, p. 339 (grifo meu): 
em Durante a construção da Muralha da China [março 1917]; os nômades-gralhas carnívoros $^{108}$ e seus "cavalos selvagens" também carnívoros ${ }^{109}$ em "Uma folha antiga" [março 1917]; o cordeiro-gato - em proporções que oscilam! - mas também cachorro e com olhos humanos em "Um cruzamento" [março 1917]:

Ich habe ein eigentümliches Tier, halb Kätzchen, halb Lamm. [...] früher war es viel mehr Lamm als Kätzchen, jetzt aber hat es von beiden wohl gleichviel. Von der Katze Kopf und Krallen, vom Lamm Größe und Gestalt, von beiden die Augen, die flackernd und mild sind, das Fellhaar, das weich ist und knapp anliegt, die Bewegungen, die sowohl Hüpfen als Schleichen sind [...]. [...]. Manchmal muß ich lachen, wenn es mich umschnuppert, zwischen den Beinen sich durchwindet und gar nicht von mir zu trennen ist. ["Du bist ja nicht nur Lamm und Katze" sage ich inm dann] Nicht genug damit, daß es Lamm und Katze ist, will es fast auch noch ein Hund sein..$^{110}$

Tenho um animal singular, metade gatinho, metade cordeiro. [...]. [...] antes era muito mais cordeiro que gatinho. Agora no entanto possui, sem dúvida, características iguais dos dois. Do gatinho, cabeça e garras; do cordeiro, tamanho e forma; de ambos, os olhos, que são flamejantes e selvagens; o pêlo, macio e aderente à pele; os movimentos, que tanto podem ser pulos como gestos furtivos. [...]. Muitas vezes tenho de rir quando me fareja, desliza entre minhas pernas e não há como apartá-lo de mim. ["Você não é de modo algum apenas cordeiro e

[...] zumal diese [Nomaden] damals geängstigt durch den Mauerbau mit unbegreiflicher Schnelligkeit wie Heuschrecken ihre Wohnsitze wechselten [...].

[...] sobretudo porque estes [os nômades], amedrontados então pela construção da muralha, mudavam suas residências com rapidez inconcebível como gafanhotos [...].

("Durante a construção da Muralha da China", em NE, p. 74, tradução modificada)

${ }^{108}$ Cf. F. Kafka, "Ein altes Blatt”, em Ein Landarzt, p. 42 (grifos meus):

Unter einander verständigen sie [die Nomaden] sich ähnlich wie Dohlen. Immer wieder hört man diesen Schrei der Dohlen.

Entre si eles [os nômades] se entendem de um modo semelhante ao das gralhas. gralhas." ("Uma folha antiga”, em MR, p. 25, tradução modificada)

e também p. 46 (grifo meu):

[...] um da Gebrüll des Ochsen nicht zu hören, den vollen allen Seiten die Nomaden ansprangen, um mit den Zähnen Stücke aus seinem warmen Fleisch zu reißen.

[...] para não ouvir os mugidos do boi que os nômades atacavam de todos os lados para arrancar com os dentes pedaços de sua carne quente." (“Uma folha antiga”, em MR, p. 26).

${ }^{109}$ Cf. F. Kafka, "Ein altes Blatt”, em Ein Landarzt, p. 44 (grifo meu):

Auch ihre Pferde fressen Fleisch; oft liegt ein Reiter neben seinem Pferd und beide nähren sich vom gleichen Fleischstück, jeder an einem Ende.

Os cavalos deles também comem carne; muitas vezes um cavaleiro fica do lado do seu cavalo e os dois se alimentam da mesma posta de carne, cada qual por uma extremidade.

(“Uma folha antiga", em MR, p. 25)

${ }^{110}$ F. Kafka, "Oktavheft D" [“Eine Kreuzung”], em KKA N1, p. 372-374 (grifos meus). Trecho riscado em KKA N1 App, p. 311. 
gato" disso ou a do ontão] Não contente com o fato de que é cordeiro e gato, quase se quer ser, ainda por cima, um cachorro. ${ }^{111}$

Hatte diese Katzen und Lammesseole auch Menschenehrgeiz?

Esta alma de gato e cordeiro tinha também ambiȩão humana? ${ }^{112}$

Es muss doshalb warton bis ihm der Atom von solbst ausgoht, wonn os mich manchmal auch wio aus vorständigen Menschenaugen ansieht, die zu verständigen Tun auffordern. ${ }^{113}$

É nocessário, pois, osperar que o alento quo o anima desapareça espontaneamente, por mais que me fite com sensatos olhos humanos que incitam um ato do sensatoz. ${ }^{114}$

Sem esquecer ainda do macaco-homem Pedro Vermelho em "Um relatório para uma
academia" [abril 1917] ${ }^{115}$ e do "fugidio" Odradek em "A preocupação do pai de família"

${ }^{111}$ F. Kafka, "Um cruzamento", em NE, p. 98-99 (a tradução do trecho riscado é minha).

${ }^{112}$ F. Kafka, "Oktavheft D" ["Eine Kreuzung"], em KKA N1 App, p. 311.

${ }^{113}$ F. Kafka, "Oktavheft D" ["Eine Kreuzung"], em KKA N1 App, p. 312 (grifo meu).

${ }^{114}$ F. Kafka, "Um cruzamento", em NE, p.100.

115 Se o relatório de Pedro Vermelho aos "eminentes senhores da academia" assinala, por um lado, sua "ascensão" ao "mundo dos homens" ("Menschenwelt"):

Durch eine Anstrengung, die sich bisher auf der Erde nicht wiederholt hat, habe ich die Durchschnittsbildung eines Europäers erreicht. (F. Kafka, "Ein Bericht für eine Akademie", em LA, p. 185-186)

Através de um esforço que até agora não se repetiu sobre a terra, cheguei à formação média de um europeu. ( $F$. Kafka, "Um relatório para uma academia", em MR, p. 71)

por outro lado, porém, ele mostra antes empenhado em expor, por meio de um sarcasmo corrosivo, a bestialidade de sua nova comunidade ("Menschengemeinschaft"/“comunidade dos homens"):

Und zur Ehre meines Lehrers: er war mir nicht böse; wohl hielt er mir manchmal die brennende Pfeife ans Fell, bis es irgendwo, wo ich nur schwer hinreichte, zu glimmen anfing, aber dann löschte er es selbst wieder mit seiner riesigen guten Hand; er war mir nicht böse, er sah ein, daß wir auf der gleichen Seite gegen die Affennatur kämpften und daß ich den schwereren Teil hatte. (F. Kafka, "Ein Bericht für eine Akademie", em LA, p. 179)

E para honra do meu professor: ele não ficava bravo comigo; é certo que às vezes ele segurava o cachimbo aceso junto à minha pele até começar a pegar fogo em algum ponto que eu não alcançava, mas ele mesmo 0 apagava depois com sua mão boa e gigantesca; ele não ficava bravo comigo, percebia que nós lutávamos do mesmo lado contra a natureza do macaco e que a parte mais pesada ficava comigo.

(“Um relatório para uma academia”, em MR, p. 69, tradução modificada).

Cf. ainda os sarcásticos comentários de Pedro Vermelho:

Einen [Schuss] in die Wange; der war leicht; hinterließ aber eine große ausrasierte rote Narbe, die mir den widerlichen, ganz und gar unzutreffenden, förmlich von einem Affen erfundenen Namen Rotpeter eingetragen hat [...]. ("Ein Bericht für eine Akademie", em $L A$, p. 152)

Um [tiro] na bochecha; este foi leve; deixou porém uma cicatriz vermelha de pelos raspados, que me valeu o nome repulsivo de Pedro Vermelho, absolutamente descabido e que só podia ter sido inventado por um macaco [...]. ("Um relatório para uma academia", em $M R$, p. 61, grifos meu, tradução modificada)

Der zweite Schuß traf mich unterhalb der Hüfte. [...]. Letzthin las ich in einem Aufsatz irgendeines der zehntausend Windhunde, die sich in den Zeitungen über mich auslassen: meine Affennatur sei noch nicht ganz unterdrückt [...]."("Ein Bericht für eine Akademie", em LA, p. 153, grifos meus)

O segundo tiro me acertou embaixo da anca. [...]. Li recentemente, num artigo de algum dos dez mil cabeças-de-vento que se manifestam sobre mim nos jornais, que minha natureza de símio ainda não está totalmente reprimida [...]. ("Um relatório para uma academia", em MR, p. 61). 
[abril 1917]. Odradek constitui, sem dúvida, uma das figuras mais extraordinárias e instigantes da produção kafkiana e, por isso mesmo, merecerá algumas considerações a mais. Assim, à impossibilidade de se determinar a etimologia e o sentido do nome deste ser:

Die einen sagen, das Wort Odradek stamme aus dem Slawischen und sie suchen auf Grund dessen die Bildung des Wortes nachzuweisen. Andere wieder meinen, es stamme aus dem Deutschen, vom Slawischen sei es nur beeinflußt. Die Unsicherheit beider Deutungen aber läßt wohl mit Recht darauf schließen, daß keine zutrifft, zumal man auch mit keiner von innen einen Sinn des Wortes finden kann. $^{116}$

Alguns dizem que a palavra Odradek deriva do eslavo e com base nisso procuram demonstrar a formação dela. Outros por sua vez entendem que deriva do alemão, tendo sido apenas influenciado pelo eslavo. Mas a incerteza das duas interpretações permite concluir, sem dúvida com justiça, que nenhuma delas procede, sobretudo porque não se pode descobrir através de nenhuma um sentido para a palavra. ${ }^{117}$

segue-se a impossibilidade de se delinear sua esquisita figura:

Es sieht zunächst aus wie eine flache sternartige Zwirnspule, und tatsächlich scheint es auch mit Zwirn bezogen; allerdings dürften es nur abgerissene, alte, aneinander geknotete, aber auch ineinander verfitzte Zwirnstücke von verschiedenster Art und Farbe sein. Es ist aber nicht nur eine Spule, sondern aus der Mitte des Sternes kommt ein kleines Querstäbchen hervor und an dieses Stäbchen fügt sich dann im rechten Winkel noch eines. Mit Hilfe dieses letzteren Stäbchens auf der einen Seite, und einer der Ausstrahlungen des Sternes auf der anderen Seite, kann das Ganze wie auf zwei Beinen aufrecht stehen. ${ }^{118}$

À primeira vista ele tem o aspecto de um carretel de linha achatado e em forma de estrela, e com efeito parece também revestido de fios; de qualquer modo devem ser só pedaços de linha rebentados, velhos, atados uns aos outros, além de emaranhados e de tipo e cor os mais diversos. Não é contudo apenas um carretel, pois do centro da estrela sai uma varetinha e nela se encaixa depois

No caso deste segundo exemplo, vale assinalar que o termo "Windhund" - junção de "Hund"/“cachorro" com "Wind"/"vento" - designa tanto o galgo (aquela raça de cachorro muito magro e extremamente veloz) quanto, em sentido pejorativo, um homem leviano ou não-confiável. Modesto Carone traduziu-o engenhosamente por "cabeça-de-vento"; tendo contudo nosso argumento em vista, esta tradução teria o problema de apagar justamente o elemento animal do termo alemão que, como vimos, desempenha também um papel estratégico. Assim, na medida em que o relatório de Pedro Vermelho instala os "homens" no limiar entre o animal e o humano; é de se concluir que a "evolução empurrada para a frente a chicote" ("vorwärts gepeitschte Entwicklung") de Pedro Vermelho rumo ao "mundo dos homens" não tenha então chegado a termo (afinal, os próprios "homens" encontram-se também detidos nesta transição).

${ }^{116}$ F. Kafka, "Die Sorge des Hausvaters", em Ein Landarzt, p. 95-96.

${ }^{117}$ F. Kafka, "A preocupação do pai de família", em Um médico rural, p. 43.

${ }^{118}$ F. Kafka, "Die Sorge des Hausvaters", em LA, p. 96-97. 
uma outra, em ângulo reto. Com a ajuda desta última vareta de um lado e de um dos raios da estrela do outro, o conjunto é capaz de permanecer em pé como se estivesse sobre duas pernas. ${ }^{119}$

Cabe ressaltar, a partir dos exemplos supracitados, como cada tentativa de delimitação desta figura é seguida muito de perto pela ressalva desta tentativa, ou seja, precisamos a todo momento corrigir a imagem que havíamos acabado de formar deste ser: assim se Odradek parece, "a princípio" ("zunächst”), "um carretel de linhas achatado e em forma de estrela", "ele, porém, não é apenas um carretel" ("es ist aber nicht nur eine Spule") ou ainda se ele parece "de fato" ("tatsächlich") "recoberto por fios", "devem entretanto ser apenas [...] pedaços de fios" ("allerdings dürften es nur [...] Zwirnstücke"). O resultado óbvio deste processo é uma imagem efetivamente instável de Odradek (porque sempre provisória e nunca confiável).

O fato de que todos os esforços em "precisar" Odradek resultam sempre em fracasso acaba por ser reconhecido pelo próprio narrador no momento em que admite:

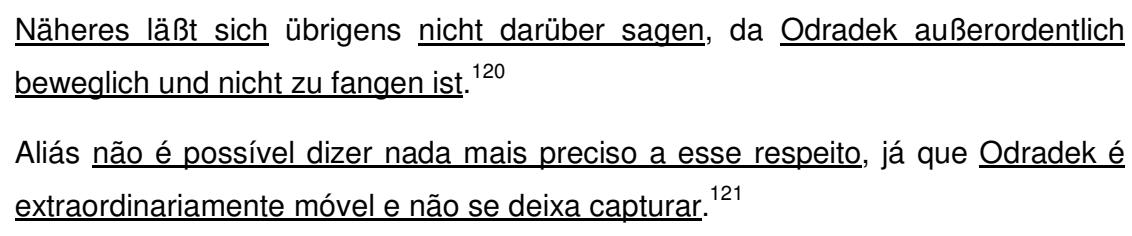
E com isso chegamos a um ponto decisivo, pois uma compreensão adequada da extraordinária mobilidade de Odradek implica que esta seja entendida em dois sentidos. Em primeiro lugar, ela se refere, é claro, à sua mobilidade física: uma mobilidade que impede Odradek de se fixar em qualquer lugar que seja. Exatamente por isso "ele se detém alternadamente no sótão, na escadaria, nos corredores, no vestíbulo" ("Er hält sich abwechselnd auf dem Dachboden, im Treppenhaus, auf den Gängen, im Flur auf."122). A propósito, o catálogo dos lugares em que Odradek se "detém alternadamente" - sendo que nesta combinação o advérbio acaba minando o próprio sentido do verbo "deter-se", pois "deter-se alternadamente" significa, a rigor, não se deter - não poderia ser mais expressivo: todos os lugares listados são surpreendentemente zonas de trânsito, de passagem, de fluxo, portanto, limiares (em outro sentido, zonas de indefinição, de indeterminação). Diante deste quadro, não é de se espantar que quando perguntado por

\footnotetext{
${ }^{119}$ F. Kafka, "A preocupação do pai de família”, em MR, p. 43-44.

${ }^{120}$ F. Kafka, "Die Sorge des Hausvaters", em LA, p. 98 (grifos meus).

${ }^{121}$ F. Kafka, "A preocupação do pai de família", em MR, p. 44.

${ }^{122}$ F. Kafka, "Die Sorge des Hausvaters", em LA, p. 99 (grifo meu).
} 
seu domicílio, Odradek responda com assustadora "clareza": "Unbestimmter Wohnsitz"123, ou seja, domicílio indefinido ou indeterminado.

Por outro lado, a extraordinária mobilidade de Odradek refere-se também à mobilidade de seu "ser", uma vez que transita - sem se deter, ou melhor, detendo-se alternadamente - entre a coisa (algo como um carretel de linha em forma de estrela etc etc etc), o humano e o vegetal (sem vida):

Natürlich stellt man an inn keine schwierigen Fragen, sondern behandelt ihn schon seine Winzigkeit verführt dazu - wie ein Kind. [...]. [...] oft ist er lange stumm, wie das Holz, das er zu sein scheint. ${ }^{124}$

É natural que não se façam perguntas difíceis, mas sim que ele seja tratado - já o seu minúsculo tamanho induz a isso - como uma criança. [...]. [...] muitas vezes ele se conserva mudo por muito tempo como a madeira que parece ser. ${ }^{125}$

Exatamente por isso Odradek também "não se deixa apanhar” (“[...] Odradek [...] nicht zu fangen ist."), pois ele escapa às malhas da definição, constituindo-se, a exemplo das outras inúmeras personagens mencionadas acima, enquanto transição ou, em outras palavras, enquanto indeterminação. ${ }^{126}$

${ }^{123}$ F. Kafka, "Die Sorge des Hausvaters", em $L A$, p. 100.

${ }^{124}$ F. Kafka, "Die Sorge des Hausvaters", em LA, p. 99-100 (grifos meus).

${ }^{125}$ F. Kafka, "A preocupação do pai de família", em MR, p. 44.

${ }^{126}$ A propósito, outra não é a razão da extrema mobilidade, sempre sublinhada por Kafka, de inúmeras outras figuras desta nova produção. Cf., por exemplo, o caçador Gracchus:

Auf dieser unendlich weiten Freitreppen treibe ich mich herum, bald oben bald unten, bald rechts bald links, immer in Bewegung. (Kafka, "Oktavheft B" ["Der Jäger Gracchus"], em KKA N1, p. 309, grifo meu)

[...] Fico dando voltas por essa escada infinitamente ampla, ora para cima, ora para baixo, ora à direita, ora à esquerda, sempre em movimento. ("O caçador Gracchus", em NE, p. 70.)

ou os nômades-gafanhotos de Durante a construção da Muralha da China:

[...] zumal diese [Nomaden] damals geängstigt durch den Mauerbau mit unbegreiflicher Schnelligkeit wie Heuschrecken ihre Wohnsitze wechselten [...].

("Oktavheft C" [Beim Bau der chinesischen Mauer], em KKA N1, p. 339, grifo meu.)

[...] sobretudo porque estes [os nômades], amedrontados então pela construção da muralha, mudavam suas residências com rapidez inconcebível como gafanhotos [...].

("Durante a construção da Muralha da China", em NE, p. 74, tradução modificada.)

ou ainda o cordeiro-gato:

[...] die Bewegungen, die sowohl Hüpfen als Schleichen sind, im Sonnenschein auf dem Fensterbrett macht es sich rund und schnurrt, auf der Wiese läuft es wie toll und ist kaum einzufangen [...].

(F. Kafka, "Oktavheft D" [“Eine Kreuzung"], em KKA N1, p. 373.)

[...] os movimentos, que tanto podem ser pulos como gestos furtivos. Ao sol, no parapeito da janela, enrodilha-se e ronrona; no prado corre como um louco e quase não se pode apanhá-lo. (“Um cruzamento", em NE, p. 98.) 
Diante do exposto, não resta dúvida de que se está com esta nova produção kafkiana "já muito distante do continente do homem" ("[...] vom Kontinent des Menschen schon weit entfernt [...]."127). Neste novo mundo atravessado de ponta a ponta por uma espécie de confusão ontológica parece de fato não ter restado muitos vestígios deste arcaico "continente do homem". Neste ponto, um confronto com a produção anterior pode se revelar produtivo; pois é significativa a distância que separa estes novos seres - cujos limites encontram-se radicalmente comprometidos, danificados - das personagens que haviam dominado a produção kafkiana até 1915. A simples enumeração destas "antigas" personagens (quase todas ainda portadoras de nome e sobrenome) já é, aliás, por si só reveladora: Georg Bendemann, Karl Roßmann, Gregor Samsa, Josef K., Blumfeld. Não há como negar que estamos aqui diante de um mundo, de modo geral, ainda dominado por homens; é também óbvio que os limites ("Grenze") deste "mundo dos homens" ("Menschenwelt") ou desta "comunidade dos homens" ("Menschengemeinschaft") - para me valer de dois termos do "crítico" Pedro Vermelho em "Um Relatório para uma academia" - já começam aqui a ser problematizados pelo escritor (ressalte-se, por exemplo, um caso extremo como Gregor Samsa). Mas é preciso também admitir que, em vista do aspecto radicalmente esquisito dos novos seres kafkianos, as personagens da produção anterior a 1916 ainda detinham contornos relativamente mais definidos.

Pensando ainda no caso de Gregor Samsa ${ }^{128}$, convém então assinalar que sua metamorfose em inseto não constitui, porém, um fenômeno isolado apenas na produção

\footnotetext{
127 "Franz Kafka: Zur zehnten Widerkehr seines Todestages" [1934], em Benjamin über Kafka, p. 19-20: "Man kann die Tiergeschichten Kafkas auf eine gute Strecke lesen, ohne überhaupt wahrzunehmen, daß es sich gar nicht um Menschen handelt. Stößt man dann auf den Namen des Geschöpfs - der Affen, des Hundes oder des Maulwurfs - so blickt man erschrocken auf und sieht, daß man vom Kontinent des Menschen schon weit entfernt ist." ("Pode-se ler as histórias de animais de Kafka por um longo trecho, sem se perceber que não se trata de forma alguma de homens. Ao se deparar então com o nome da criatura - macaco, cachorro ou toupeira - ergue-se os olhos espantado e se vê que se está já muito distante do continente do homem.") A propósito, uma formulação parecida deste trecho pode ser encontrada já na palestra radiofônica sobre Kafka proferida por Benjamin em julho de 1931 (cf. W. Benjamin, "Franz Kafka: Beim Bau der chinesischen Mauer", em Benjamin über Kafka, p. 43).

${ }^{128}$ A respeito da metamorfose de Gregor Samsa em inseto, o crítico Modesto Carone assinala com propriedade que "é evidente que o tema da metamorfose não é novo em literatura: os mitos clássicos e as fábulas, as narrativas dos povos primitivos e os contos de fadas são ricos em acontecimentos como esse. Mas nenhum leitor esclarecido fica perturbado com eles, não só porque essas metamorfoses em geral são reversíveis, mas também porque podem ser logo percebidas como manifestações de um estágio de consciência ingênuo, pré-científico, que exime o leitor de julgá-los segundo os padrões de sua própria experiência. Assim é que nós aceitamos que Circe, na Odisséia, metamorfoseie os companheiros de Ulisses em porcos, ou que, num conto de Grimm, o filho do rei vire sapo até que a princesa o devolva à sua condição natural - justamente porque nestes casos vigora o princípio da diferença entre o mundo empírico conhecido e o mundo mágico, fantástico ou irônico da poesia - o que nos coloca na postura certa enquanto leitores. É esse princípio que falta em $A$ metamorfose, e talvez seja por isso que dela se desprende uma sensação
} 
até 1915, mas uma ocorrência única na produção kafkiana como um todo. $E$ isso por duas razões em especial. Em primeiro lugar, as demais "metamorfoses" que se operam na produção de Kafka - e repare que elas voltarão a ocorrer apenas a partir do final de 1916 - percorrem o sentido contrário ao da metamorfose de Gregor, ou seja, do animal para o humano: pense-se em Bucéfalo em "Um novo advogado" ou em Pedro Vermelho em "Um Relatório para uma academia". Em segundo lugar, as futuras "metamorfoses" não irão se constituir como metamorfoses, não ao menos no sentido de uma mudança acabada ou completa de forma. Explico-me: "Als Gregor Samsa eines Morgens aus unruhigen Träume erwachte, fand er sich in seinem Bett zu einem ungeheueren Ungeziefer verwandelt." ${ }^{129}$ ("Quando certa manhã Gregor Samsa acordou de sonhos intranqüilos encontrou-se em sua cama metamorfoseado num inseto monstruoso" ${ }^{130}$ ); ou seja, a metamorfose neste caso está concluída, não há mais aqui um processo, Gregor Samsa é um "inseto monstruoso". Mas o que é Bucéfalo? O que é Pedro Vermelho? A estas perguntas não há como responder de forma categórica; e a razão reside no fato de que as "metamorfoses" destes seres não se completaram: eles se encontram como que detidos precisamente na transição, ou seja, no limiar entre o animal e o humano. Nesse sentido, as "metamorfoses" que ocorrem na produção kafkiana a partir do final de 1916 constituem antes exemplos de metamorfoses emperradas ou suspensas.

Dito isso, convém lembrar que além da aparição do "inseto monstruoso" em $A$ metamorfose [novembro 1912], a produção kafkiana anterior a 1916 conhecerá apenas outras duas irrupções de seres estranhos a este "mundo de homens". Estas outras aparições se dão, não por acaso, em dois fragmentos do final do ciclo produtivo de 19141915, como que anunciando então a produção futura: a saber, a "toupeira gigante" ("Riesenmaulwurf"131) em O mestre escola da aldeia de dezembro de 1914 e as "duas bolas esquisitas" ("zwei komische Bälle"132) que se movem de forma autônoma em Blumfeld, um solteiro de meia-idade do final de janeiro de 1915.

Contudo e é preciso ter esta diferença em conta, todas estas irrupções ainda se faziam acompanhar por um sobressalto, mesmo que temporário, por parte das demais personagens que as presenciam. Em $O$ mestre escola da aldeia, o desacreditado professor da aldeia, que sofre "diante da atitude desdenhosa das personalidades que

extraordinariamente perturbadora e penosa que nos põe numa atitude de defesa." (M. Carone, "O parasita da família", em Lições de Kafka, p. 15.)

${ }^{129}$ F. Kafka, Die Verwandlung, em KKA D, p. 115.

${ }^{130}$ F. Kafka, A metamorfose, p. 7.

${ }^{131}$ F. Kafka, "Dorfschullehrer-Konvolut" [Der Dorfschullehrer], em KKA N1, p. 194.

${ }^{132}$ F. Kafka, "Blumfeld-Konvolut" [Blumfeld, ein älterer Junggeselle], em KKA N1, p. 233. 
impunham o tom", defende em seu relatório justamente o caráter "sobrenatural" (insólito", "fantástico") da toupeira gigante:

\begin{abstract}
In welcher Zerstreutheit er [der Gelehrte] dem langen Bericht des Lehrers zuhörte, den dieser an der Hand seiner Schrift erstattete, zeigte sich in der Bemerkung, die er nach einiger scheinbarer Überlegung machte. "Gewiß es gibt verschiedene Maulwürfe, kleine und große. Die Erde ist doch in ihrer Gegend besonders schwarz und schwer. Nun, sie gibt deshalb auch den Maulwürfen besonders fette Nahrung und sie werden ungewöhnlich groß." "Aber so groß doch nicht", rief der Lehrer und $\mathrm{ma} \beta$, in seiner Wut ein wenig übertreibend, zwei Meter an der Wand ab. "O doch", antwortete der Gelehrte, dem das Ganze offenbar sehr spaßhaft vorkam, "warum denn nicht?"133

O tamanho da indiferença com que ele [o sábio] escutou o longo relatório do professor - que este havia feito com o manuscrito na mão - ficou demonstrado na observação que, depois de alguma meditação aparente, ele manifestou: Certamente existem toupeiras diversas, pequenas e grandes. A terra, na região em que se encontram, é particularmente preta e pesada. Ora, ela oferece, por causa disso, também às toupeiras, alimentação especialmente nutritiva e elas se tornam grandes fora do que é comum. - Mas tão grandes assim, não! - gritou o professor e, exagerando um pouco em sua raiva, mediu dois metros na parede. Oh, sim - respondeu o sábio, a quem tudo aquilo evidentemente causava a maior graça. - Por que não? ${ }^{134}$
\end{abstract}

Em Blumfeld, um solteiro de meia-idade, o protagonista toma a aparição das duas bolas esquisitas que se movem de forma autônoma por "bruxaria" ("Zauberei"):

Er schließt eilig die Tür auf und dreht das elektrische Licht auf. Auf diesen Anblick war er nicht vorbereitet. Das ist ja Zauberei, zwei kleine weiße blaugestreifte Celluloidbälle springen auf dem Parkett nebeneinander auf und ab; schlägt der eine auf den Boden, ist der andere in der Höhe und unermüdlich führen sie ihr Spiel aus. Einmal im Gymnasium hat Blumfeld bei einem bekannten elektrischen Experiment kleine Kügelchen ähnlich springen sehn, diese aber sind verhältnismäßig große Bälle, springen im freien Zimmer und es wird kein elektrisches Experiment angestellt. [...]. Blumfeld greift in die Luft, um festzustellen, ob sie nicht etwa an irgendwelchen Fäden hängen, nein, sie bewegen sich ganz selbstständig. ${ }^{135}$

Ele abre às pressas a porta e acende a luz elétrica. Para aquela visão ele não estava preparado. É uma bruxaria - duas pequenas bolas de celulóide, brancas, com estrias azuis, saltam sobre o assoalho, uma ao lado da outra e de cá para lá; quando uma bate no chão, a outra está no alto e assim, incansáveis, executam o

\footnotetext{
${ }^{133}$ F. Kafka, "Dorfschullehrer-Konvolut" [Der Dorfschullehrer], em KKA N1, p. 196-197 (grifo meu).

${ }^{134} \mathrm{~F}$. Kafka, O mestre-escola da aldeia, em NE, p. 11-12 (tradução ligeiramente modificada).

${ }^{135}$ F. Kafka, "Blumfeld-Konvolut" [Blumfeld, ein älterer Junggeselle], em KKA N1, p. 232-233 (grifos meus).
} 
seu jogo. Um vez no curso secundário, Blumfeld viu, durante uma conhecida experiência elétrica, pequeninas esferas saltarem de forma semelhante, mas, em comparação com aquelas, estas são bolas relativamente grandes, saltam no aposento livre e nenhum experimento elétrico está sendo realizado. [...]. Blumfeld passa a mão no ar para verificar se elas não pendem, por acaso, de fios; não, elas se movem com completa autonomia. ${ }^{136}$

Já em $A$ metamorfose, as coisas parecem um pouco mais complicadas, pois, ao passo que se pode evidentemente ressaltar a sobriedade com a qual Gregor se percebe inseto, cabe assinalar que esta tranqüilidade não é, de modo algum, compartilhada pelo restante das personagens, tanto assim que Gregor inseto será relegado à solidão de seu quarto e todas as suas futuras excursões para fora deste "domínio" acabarão em desastres; nesse sentido, não custa recordar a primeira exibição pública de Gregor inseto:

Er [Gregor] war noch mit jener schwierigen Bewegung beschäftigt und hatte nicht Zeit, auf anderes zu achten, da hörte er schon den Prokuristen ein lautes "Oh!" ausstoßen [...] und nun sah er ihn auch, wie er, der der Nächste an der Türe war, die Hand gegen den offenen Mund drückte und langsam zurückwich, als vertreibe inn eine unsichtbare, gleichmäßig fortwirkende Kraft. Die Mutter [...] sah zuerst mit gefalteten Händen den Vater an, ging dann zwei Schritte zu Gregor hin und fiel inmitten ihrer rings um sie herum sich ausbreitenden Röcke nieder, das Gesicht ganz unauffindbar zu ihrer Brust gesenkt. Der Vater ballte mit feindseligem Ausdruck die Faust, als wolle er Gregor in sein Zimmer zurückstoßen, sah sich dann unsicher im Wohnzimmer um, beschattete dann mit den Händen die Augen und weinte, daß sich seine mächtige Brust schüttelte. [...]. "Nun”, sagte Gregor und war sich dessen wohl bewußt, daß er der einzige war, der die Ruhe bewahrt hatte, "ich werde mich gleich anziehen, die Kollektion zusammenpacken und wegfahren."137

[Gregor] Estava ainda ocupado com essa manobra difícil, sem ter tido tempo para atentar em outra coisa, quando ouviu o gerente soltar um "oh!" alto [...] e então Gregor o viu também: era o mais próximo da porta e comprimia a mão sobre a boca, enquanto recuava devagar, como se o impelisse uma força invisível que continuasse agindo de modo constante. A mãe [...] a princípio fitou o pai com as mãos entrelaçadas, depois deu dois passos em direção a Gregor e caiu no meio das saias que se espalhavam ao seu redor, o rosto totalmente afundado no peito. O pai cerrou o punho com expressão hostil, como se quisesse fazer Gregor recuar para dentro do quarto, depois olhou em volta de si, inseguro, na sala de estar, em seguida cobriu os olhos com as mãos e chorou a ponto de sacudir o peito poderoso. [...]. - Bem - disse Gregor, consciente de que era o único que

\footnotetext{
${ }^{136}$ F. Kafka, Blumfeld, um solteiro de meia idade, em NE, p. 33-34 (tradução modificada).
}

${ }^{137}$ F. Kafka, Die Verwandlung, em KKA D, p. 134-135 (grifo meu). 
havia conservado a calma -, vou logo me vestir, pôr o mostruário na mala e partir de viagem. ${ }^{138}$

Não encontraremos mais vestígios destes sobressaltos na produção que se inicia em 1916. A partir daqui os novos e esquisitos seres kafkianos passam a se mover sem cerimônia em meio às demais personagens e sem que estas esbocem quase nenhuma reação, aceitando tranquilamente "a existência uns dos outros como um fato divino"139.

Em meio a este mundo da desmedida - contornos temporais e espaciais fluidos e movediços - e da confusão ontológica - distinções problemáticas entre homens, animais, plantas e coisas -, outro dado sintomático contribuirá para uma percepção ainda mais aguçada deste mundo como emaranhado in-finito, como mundo caracterizado pela radical ausência de linhas definidas e recortes precisos: a significativa supressão da fronteira entre vivos e mortos.

Isso posto, não custa assinalar que até 1915, a morte - como nos lembra Lukács, "o limite em si" ("die Grenze an sich"140) - parecia ainda funcionar como uma espécie de limite interno (e, em certo sentido, também externo) a esta produção. Dito de outro modo, as personagens dos ciclos produtivos anteriores ainda puderam encontrar na morte 0 termo de suas existências, sendo que este fim coincidia, de forma muito próxima, com a própria interrupção da narrativa (nesse sentido, então, um limite "externo"): em $O$ veredicto [setembro 1912], Georg Bendemann cumpre a sentença proferida pelo paitribunal e se afoga; em A metamorfose [novembro 1912], Gregor Samsa, ao cabo de suas aventuras como inseto monstruoso, deixa escapar de suas ventas "o último fôlego"; Josef K., depois de uma arrastada andança em torno do tribunal (que a rigor não termina!), acaba por ser executado no "desfecho" de O processo [1914-1915]; em Na colônia penal [outubro 1914], o próprio oficial também se torna vítima fatal do "aparelho singular" (sem mencionar uma possível execução do protagonista Karl Roßmann em $O$ desaparecido [1912-1914], a se levar em conta uma anotação do próprio escritor datada de setembro de 1915: "Roßmann e K., o inocente e o culpado, ambos finalmente assassinados, sem distinção; o inocente de forma mais leve, mais posto de lado do que abatido."141

\footnotetext{
${ }^{138}$ F. Kafka, A metamorfose, p. 24-25.

${ }^{139}$ Para me valer aqui de um trecho do fragmento "Um cruzamento":

[...] die Tiere sahen einander ruhig aus Tieraugen und nahmen offenbar ihr Dasein als göttliche Tatsache gegenseitig hin" ("Oktavheft B" ["Eine Kreuzung"], em KKA N1, p. 373)

Os animais olhavam-se tranquilamente com olhos de animais e aceitavam de forma patente a existência uns dos outros como um fato divino. ("Um cruzamento", em NE, p. 99, tradução modificada.)

${ }^{140}$ G. Lukács apud W. Benjamin, Ursprung des deutschen Trauerspiels, p. 314 (tradução brasileira, p. 158).

${ }^{141}$ F. Kafka, "Elftes Heft" [30.09.1915], KKA T, p. 757: "Roßmann und K., der Schuldlose und der Schuldige, schließlich beide unterschiedslos strafweise umgebracht, der Schuldlose mit leichterer Hand, mehr zur Seite geschoben als niedergeschlagen."
} 
Obviamente poderíamos lembrar ainda das narrativas ligadas ao complexo do romance $O$ processo e publicadas de forma autônoma pelo próprio escritor: refiro-me a "Diante da lei" - que se encerra com a morte do homem do campo seguida pelo fechamento da porta da lei - e "Um sonho", onde a personagem Josef K. cava o seu próprio túmulo e em seguida mergulhar nele.

Com o ciclo produtivo que se inaugura ao final de 1916 este caráter restritivo da morte perde a sua vigência. Sem qualquer cerimônia, uma horda de mortos-vivos passa então a desfilar por esta nova produção: pense-se nos "senhores da tumba" (“Gruftherren”), ou seja, nos "sagrados ancestrais" ("selige Vorfahren”) do príncipe regente em O guarda da tumba [novembro/dezembro 1916] que todas as noites abandonam seus sarcófagos e tentam escapar do parque, sendo então "contidos" pelo guarda; ou no caçador Gracchus, literalmente à deriva entre a vida e a morte em "O caçador Gracchus" $^{\text {"142 }}$ [janeiro/fevereiro e abril 1917]:

"Sind Sie tot?" "Ja", sagte der Jäger, "wie Sie sehn. [...]. Seitdem bin ich tot." "Aber Sie leben doch auch" sagte der Bürgermeister. "Gewissermaßen", sagte der Jäger, "gewissermaßen lebe ich auch. Mein Todeskahn verfehlte die Fahrt, eine falsche Drehung des Steuers, ein Augenblick der Unaufmerksamkeit des Führers, eine Ablenkung durch meine wunderschöne Heimat, ich weiß nicht was es war, nur das weiß ich, daß ich auf der Erde blieb und daß mein Kahn seither die irdischen Gewässer befährt [...]. [...]. Mein Kahn ist ohne Steuer, er fährt mit dem Wind der in den untersten Regionen des Todes bläst." ${ }^{\text {"143 }}$

"O senhor está morto?" "Sim" disse o caçador, "como o senhor vê, estou morto. [...]. Desde então estou morto." "Mas o senhor também vive" disse o prefeito. "Num certo sentido, sim" disse o caçador "num certo sentido eu estou vivo também. Meu barco fúnebre errou o caminho, uma volta equivocada do leme, um instante de desatenção do piloto, um desvio através da minha pátria maravilhosa, não sei o que foi, só sei que permaneci na Terra e que meu barco, desde então, navega por águas terrenas [...]. [...]. Meu barco não tem leme, navega com o vento que sopra na regiões inferiores da morte."144

Portador de um destino, sem dúvida, ainda mais aterrador que o do próprio Gracchus, há que se assinalar - em um fragmento datado de outubro de 1917 (ou seja, já do segundo momento deste ciclo produtivo) -, a figura do morto-vivo Dom Quixote; na (per)versão

\footnotetext{
${ }^{142}$ A rigor, Kafka nunca escreveu uma narrativa com este título. O motivo do caçador Gracchus distribui-se por um complexo de seis fragmentos, sendo que quatro deles foram escritos entre janeiro e fevereiro de 1917 e outros dois em abril deste mesmo ano (sendo que destes dois fragmentos, um está contido em seus Diários). A conhecida narrativa "O caçador Gracchus" é uma invenção do seu amigo Max Brod que efetuou uma fusão arbitrária dos fragmentos escritos em janeiro/fevereiro de 1917, desconsiderando os dois escritos em abril.

${ }^{143}$ F. Kafka, "Oktavheft B" ["Der Jäger Gracchus”], em KKA N1, p. 309-311.

${ }^{144}$ F. Kafka, "O cacador Gracchus", em NE, p. 69-72.
} 
kafkiana do "cavaleiro da triste figura", este buscará, depois de morto, inutilmente se matar:

\begin{abstract}
Eine der wichtigsten Don Quichotischen Taten, aufdringlicher als der Kampf mit der Windmühle, ist der Selbstmord. Der tote Don Quichote will den toten Don Quichote töten; um zu töten, braucht er aber eine lebendige Stelle, diese sucht er nun mit seinem Schwerte ebenso unaufhörlich wie vergeblich. Unter dieser Beschäftigung rollen die zwei Toten, als unauflöslicher Purzelbaum, durch die Zeiten.

Um dos feitos mais importantes de Dom Quixote, ainda mais disparatado do que o combate com o moinho de vento, é o suicídio. O Dom Quixote morto quer matar o Dom Quixote morto; para matá-lo ele precisa contudo de um ponto vivo, que ele então busca com sua espada interminavelmente e em vão. Nesta ocupação rolam os dois mortos, como cambalhota indissolúvel, através dos tempos. ${ }^{145}$
\end{abstract}

Contido no chamado "Caderno in-oitavo 7" e escrito em outubro de 1917, este pequeno fragmento situa-se ao lado daquele que foi destacado e intitulado por Max Brod de "A verdade sobre Sancho Pança". Porém, ao contrário do reconhecimento notório obtido por este último fragmento, "a verdade sobre Dom Quixote" acabaria por ser curiosamente desprezada pela crítica. Há razões de sobra para imaginar que este fragmento teria atraído a atenção de críticos como Benjamin e Adorno: como se sabe, Benjamin tinha especial apreço pela narrativa "A verdade sobre Sancho Pansa", tanto que a escolheu para fechar seu conhecido ensaio sobre Kafka; já Adorno sempre se mostrou particularmente sensível ao "triste destino" do morto-vivo Gracchus (cf. as várias referências a Gracchus em seu ensaio sobre Kafka e também em sua Teoria estética).

Voltando porém ao primeiro momento deste ciclo, outros exemplos poderiam ainda ser elencados, ainda que os próprios textos não se refiram explicitamente a eles como mortos-vivos. Pense-se assim na narrativa "No sótão" [novembro/dezembro 1916], onde inúmeros indícios apontam para a morte do empoeirado caçador-tralha Hans Schlag, esquecido no sótão "em meio à tralha de um século inteiro" ("inmitten des Gerümpels eines ganzen Jahrhunderts"). A propósito, não há dúvida de que estamos aqui diante de um precursor do caçador morto-vivo Gracchus; é preciso, contudo, destacar uma diferença notável: enquanto Gracchus, a exemplo de Odradek, se distingue por sua extrema mobilidade, por estar "sempre em movimento" ("immer in Bewegung"), o caçador Hans é caracterizado expressamente pela "ausência de movimento" (“Bewegungslosigkeit"), donde resulta inclusive o seu caráter empoeirado ${ }^{146}$. Não

\footnotetext{
${ }^{145}$ F. Kafka, "Okatvheft G" [fragmento sem título], em KKA N2, p. 38-39.

${ }^{146}$ A respeito deste seu caráter empoeirado, cf. o comentário do filho do advogado ao tocar Hans:
} 
esqueçamos, porém, de Bucéfalo ["O novo advogado"; janeiro/fevereiro 1917], outro exemplo bastante interessante: afinal, em um mundo no qual não mais existe nenhum grande Alexandre ${ }^{147}$, como entender e explicar a esquisita permanência de seu cavalo de batalha - reza a lenda morto em combate - através dos séculos?

Outro caso notável pode ser encontrado na narrativa "O cavaleiro do balde" [janeiro/fevereiro 1917] que fazia parte, a princípio, da coletânea Um médico rural, mas acabou por razões ignoradas sendo removida por Kafka do conjunto pouco antes de sua publicação. O próprio escritor publicou-a porém em dezembro de 1921 no jornal Prager Presse. O primeiro título concebido por Kafka para esta narrativa era "Der zweite Reiter" ("O segundo cavaleiro"); tal título estabeleceria assim um contraponto à narrativa "Ein Reiter" ("Um cavaleiro") - título original, por sua vez, da narrativa que ficaria conhecida como "A próxima aldeia", escrita poucos dias antes: entre dezembro de 1916 e janeiro de 1917. Enfim, para não morrer congelado ("Ich muß Kohle haben, ich darf doch nicht erfrieren [...]." ${ }^{148}$ ), o "herói" de "O cavaleiro do balde" precisará montar um balde vazio na esperança de obter "uma pá do pior carvão". Ao malogro de sua cavalgada pela sobrevivência - como se sabe, a mulher do carvoeiro o enxota com o seu avental ${ }^{149}$ segue-se a sua desaparição/morte:

Und damit steige ich in die Regionen der Eisgebirge und verliere mich auf Nimmerwiedersehn. ${ }^{150}$

$\mathrm{E}$ com isso ascendo às regiões das montanhas geladas e me perco para nunca mais. $^{151}$

"So staubig bist Du!" (F. Kafka, "Oktavfheft A" [“Auf dem Dachboden”], em KKA N1, p. 273)

"Você está tão empoeirado!"

Já com relação à sua "ausência de movimento" de Hans, vale também destacar a descrição de seu rosto como facies hippocratica:

Sein Gesicht zeigte, als er [der Jäger Hans] Hans [der Sohn des Advokaten] erblickte, weder Schrecken noch Staunen, sondern nur Stumpfheit [...].

(F. Kafka, "Oktavfheft A" [“Auf dem Dachboden"], em KKA N1, p. 272, grifos meus).

"Quando ele [o caçador Hans] avistou Hans [o filho do advogado], seu rosto não mostrou nem espanto nem admiração, mas apenas embotamento [...]."

${ }^{147}$ Cf. F. Kafka, "Der neue Advokat", em Ein Landarzt, p. 3: "Heute - das kann niemand leugnen - gibt es keinen großen Alexander."/"Hoje - isso ninguém pode negar - não existe nenhum grande Alexandre." ("O novo advogado", em Um médico rural, p. 11.)

${ }^{148}$ F. Kafka, "Oktavheft B" ["Der Kübelreiter”], em KKA N1, p. 316. ("O cavaleiro do balde”, em M. Carone, Lição de Kafka, p. 7: "Preciso de carvão; certamente não posso morrer congelado [...].")

${ }^{149}$ F. Kafka, "Oktavheft B" ["Der Kübelreiter"], em KKA N1, p. 316: "Sie sieht nichts und hört nichts, aber dennoch löst sie das Schürzenband und versucht mich mit der Schürze fortzuwehn. Leider gelingt es." ("O cavaleiro do balde", em M. Carone, Lição de Kafka, p. 9: "Ela não vê nem ouve nada, no entanto desamarra o cinto do avental e tenta me enxotar com ele. Infelizmente consegue.")

${ }^{150}$ F. Kafka, "Oktavheft B” [“Der Kübelreiter”], em KKA N1, p. 316. 
Se este final do texto publicado ainda em vida pelo escritor coincide com a desaparição/morte da personagem, o mesmo, porém, não ocorre com o texto que consta no manuscrito kafkiano. Aqui a narrativa prossegue de maneira muito curiosa por mais um parágrafo antes de sua "verdadeira" interrupção; ou seja, com o cavaleiro sobrevivendo ao seu próprio "fim". Nesta continuação o cavaleiro não está mais sobre a "terra invernal" e a sua cavalgada perdeu o sentido, transformando-se em caminhada - ao que tudo indica sem fim - na qual a personagem passa então a carregar sobre o ombro a sua antiga cavalgadura. Estaríamos portanto na presença de outro ilustre morto-vivo:

\footnotetext{
Ist hier wärmer, als unten auf der winterlichen Erde? Weiss ragt es rings, mein Kübol das oinzig Dunkle. War ich früher hoch, bin ich jetzt tief, der Blick zu den Bergen renkt mir den Hals aus. Weissgefrorene Eisfläche, der Himmel, strichwoise durchschnitten von den Bahnen vorschwundener Schlittschuhläufer. Auf dem hohen keinen Zoll breit einsinkenden Schnee folge ich der Fussspur der kleinen arktischen Hunde. Mein Roiten hat den Sinn verloren, ich bin abgestiegen und trage den Kübol auf der Achsel.

Aquiestá mais quente do que lá embaixo sobre a terra invernal? Obranco ergueso ao rodor; mou baldo, o único negrume. Estava ou antes nas alturas, agora estou na profundidado; O olhar para as montanhas deslocou-mo o pescoço. Suporfício de golo congolada o branca, o-céu, rasgado om alguns pontos polas trilhas de patinadores desaparocidos. Sobro a alta novo ou sigo-o rastro dos pés de um pequeno cachorro ártico. Minha cavalgada perdeu o sentido, ou desmontei do baldo o carrogo-0 sobro o- ombro. ${ }^{152}$
}

Dentro ainda deste tópico sobre mortos-vivos, há que se considerar os questionamentos do narrador de "A preocupação do pai de família" [abril 1917] a respeito da "finitude/infinitude" de Odradek. Como se sabe, após o fracasso em delimitar este ser e após sintomaticamente assinalar a sua extraordinária mobilidade, o próprio narrador acabará por instalá-lo no "domicílio indefinido" (“Unbestimmter Wohnsitz") entre a vida e a morte:

Kann er denn sterben? Alles, was stirbt, hat vorher eine Art Ziel, eine Art Tätigkeit gehabt und daran hat es sich zerrieben; das trifft bei Odradek nicht zu. Sollte er also einstmals etwa noch vor den Füßen meiner Kinder und Kindeskinder mit nachschleifendem Zwirnsfaden die Treppe hinunterkollern? ${ }^{153}$

151 F. Kafka, "O cavaleiro do balde", em M. Carone, Lição de Kafka, p. 10. Carone traduziu "auf Nimmerwiedersehn" por "para nunca mais"; outras opções seriam: "para todo o sempre" ou "para nunca mais voltar".

${ }^{152}$ F. Kafka, "Oktavheft B” [“Der Kübelreiter”], em KKA N1 App, p. 275.

${ }^{153}$ F. Kafka, "Die Sorge des Hausvaters", em LA, p. 101. 
Será que ele pode morrer? Tudo o que morre teve antes uma espécie de meta, um tipo de atividade e nela se desgastou, não é assim com Odradek. Será então que a seu tempo ele ainda irá rolar escada abaixo diante dos pés dos meus filhos e dos filhos dos meus filhos, arrastando atrás de si os fios do carretel? ${ }^{154}$

A propósito, não se pode deixar de sublinhar que Kafka já havia operado esta conexão entre "mobilidade extraordinária" e não-morte, ou melhor, morte danificada em "O caçador Gracchus" [janeiro/fevereiro 1917]. Como se sabe, Gracchus - que após a sua morte viaja "por todos os países da Terra" sem de fato se deter em nenhum deles (ou "detendo-se alternadamente", a exemplo de Odradek!) - encontra-se também sempre em movimento "na grande escada que leva para o alto"; entre o aquém e o além, ele fica dando voltas "por essa escadaria infinitamente ampla, ora para cima, ora para baixo, ora à direita, ora à esquerda, sempre em movimento"155: "Estou sempre em movimento. Mas, se tomo o impulso máximo e lá em cima já se ilumina para mim o portal, acordo no meu velho barco, encalhado em alguma água terrena, desolado."156 Adorno, aliás, em seu ensaio sobre Kafka traçou com argúcia o paralelo entre Gracchus e Odradek, sem contudo atentar para a sintomática mobilidade destas personagens:

\footnotetext{
A zona na qual não se pode morrer é ao mesmo tempo a terra de ninguém entre o homem e a coisa: nessa terra Odradek, visto por Benjamin como um anjo no estilo de Klee, encontra-se com Gracchus, a modesta imitação de Nimrod. A compreensão do todo dependerá da compreensão dessas produções mais radicais, incomensuráveis, e de algumas outras que igualmente se afastam da idéia corrente que se tem sobre Kafka. ${ }^{157}$
}

Dito isso, faz-se necessário um pequeno reparo. Em que pese a ordem adotada por nossa exposição, cumpre assinalar que a suspensão da morte na produção de Kafka precede, a rigor, a entrada em cena daqueles inúmeros seres esquisitos. Fica-se então com a forte impressão de que, ao abrir no final de novembro de 1916 os portões do mausoléu em $\underline{O}$ guarda da tumba - e este é o primeiro texto kafkiano a operar de fato a suspensão da morte em sua produção -, Kafka não estava liberando apenas "os grandes mortos" (“die großen Toten”), ou seja, os sagrados ancestrais do príncipe regente; pois a estes se seguem, em vários outros textos kafkianos e em ritmo desconcertante, inúmeros outros seres esquisitos, de contornos problemáticos. Esta nova e vasta galeria de seres danificados (composta tanto por incontáveis seres híbridos quanto por inúmeros mortos-

\footnotetext{
${ }^{154}$ F. Kafka, "A preocupação do pai de família", em MR, p. 45.

${ }^{155}$ F. Kafka, "O caçador Gracchus", em NE, p. 70, grifo meu.

${ }^{156}$ F. Kafka, "O cacador Gracchus", em NE, p. 70, grifo meu.

${ }^{157}$ T. W. Adorno, "Anotações sobre Kafka", em Prismas, p. 260.
} 
vivos) será a partir daqui o objeto privilegiado do escritor que passará então a explorá-los de forma metódica.

Assinale-se ainda que na esteira desta produção virá sintomaticamente à tona em novembro deste mesmo ano na correspondência do escritor a referência a uma "vida nãovivida" ("nichtgelebtes Leben") ${ }^{158}$. Que o termo desta "vida não-vivida", desta vida danificada seja uma morte também danificada não deve pois causar espanto (cada uma delas estampa, a seu turno, um dos lados de uma mesma moeda). Afinal, o que de fato não vive pode morrer? Ou ainda: o que não acaba de morrer terá, com efeito, vivido? Alguns anos mais tarde, em 1921, este motivo voltará à tona em uma outra bela anotação dos diários:

Derjenige der mit dem Leben nicht lebendig fertig wird, braucht die eine Hand, um die Verzweiflung über sein Schicksal ein wenig abzuwehren - es geschieht sehr unvollkommen - mit der andern Hand aber kann er eintragen, was er unter den Trümmern sieht, denn er sieht anderes und mehr als die andern, er ist doch tot zu Lebzeiten und der eigentlich Überlebende. Wobei vorausgesetzt ist, daß er nicht beide Hände und mehr als er hat, zum Kampf mit der Verzweiflung braucht. ${ }^{159}$

Aquele que não acaba por tornar a [própria] vida viva precisa de uma mão para se defender um pouco do desespero sobre o seu destino - acontece muito imperfeitamente -; com a outra mão, porém, ele pode registrar o que vê entre os escombros, pois ele vê outras coisas e mais do que os outros; ele está, com efeito, morto em vida e é o verdadeiro sobrevivente. Pressuposto nisto que ele não precise de ambas as mãos e até mais do que ele tem para o combate com o desespero.

Isso posto, não se pode deixar de destacar que todos estes abalos que se operam nos meandros da produção de Kafka a partir do final de 1916 no sentido de uma supressão generalizada de limites e contornos precisos - coordenadas espaciais e

\footnotetext{
${ }^{158}$ F. Kafka, Briefe 1902-1924, p. 195 (carta a Max Brod datada de novembro de 1917).

${ }^{159}$ F. Kafka, "Zwölftes Heft" [19.10.1921], em KKA T, p. 867. Cf. porém também carta a Max Brod datada de julho de 1922 [Briefe 1902-1924, p. 385]: "Eu poderia viver e não vivo. [...]. Eu estive morto minha vida inteira e agora eu morrerei realmente." No posfácio que escreveu para a sua tradução de Minima Moralia de Adorno, Gabriel Cohn anota com pertinência: "A vida não vive, lembra Adorno na epígrafe que escolheu para a primeira parte do livro. Para viver ela deveria ser de fato vida, vida verdadeira; precisamente aquilo que não é nas condições presentes, cuja referência histórica é a sociedade burguesa de perfil capitalista. Adorno não cansa de mostrar como essa vida lesada, danificada, prejudicada impregna de tal modo nossa experiência (pois é de nós que se trata, incluindo ele próprio) que a saída se apresenta como impossível. ('Abre-te Sésamo, quero sair' é o epigrama que ele adota como epígrafe em outra obra). Tudo se torna impossível quando a rede de relações pré-formadas se vai cerrando até constituir uma totalidade fechada [...]. Por isso mesmo, longe de ser a própria verdade 'o todo é o não-verdadeiro', ao contrário do que pretendia Hegel. No entanto, quando tudo se apresenta como impossível o menor gesto que desate um dos nós da totalidade pode também desatar a irrupção do possível, daquilo que em Adorno aparece designado com termos como reconciliação e redenção." (G. Cohn, "Alguns problemas de leitura e tradução de Minima Moralia" [Posfácio], em T. W. Adorno, Minima Moralia, p. 250-251.)
} 
temporais movediças; seres híbridos, ontologicamente confusos; supressão da fronteira entre vivos e mortos - mostravam-se, a seu turno, intimamente articulados a uma manobra estética mais ampla e decisiva; uma manobra que por sua vez investia-se contra os seus próprios limites, tornando-os mais imprecisos e passando assim a expor como nunca antes a má infinitude da própria forma. 


\section{Entre a semidestruição e o semiacabamento}

Das Schreiben versagt sich mir. Daher Plan der selbstbiographischen Untersuchungen. Nicht Biographie, sondern Untersuchung und Auffindung möglichst kleiner Bestandteiler. Daraus will ich mich dann aufbauen so wie einer, dessen Haus unsicher ist, daneben ein sicheres aufbauen will, womöglich aus dem Material des alten. Schlimm ist es allerdings wenn mitten im Bau seine Kraft aufhört und er jetzt statt eines zwar unsichern aber doch vollständigen Hauses, ein halbzerstörtes und ein halbfertiges hat, also nichts. Was folgt ist Irrsinn, also etwa ein Kosakentanz zwischen den zwei Häusern, wobei der Kosak mit den Stiefelabsätzen die Erde solange scharrt und auswirft, bis sich unter ihm sein Grab bildet. ${ }^{160}$

A escrita se nega a mim. Por isso, o plano de investigações autobiográficas. Não biografia, mas sim investigação e descoberta dos menores elementos possíveis. A partir disso eu quero então me construir assim como alguém que tem uma casa insegura e ao lado dela quer construir uma segura, se possível com o material da antiga. É, no entanto, terrível se em meio à construção sua força acaba e, ao invés de uma casa insegura mas completa, ele agora tem uma semidestruída e uma semiacabada, ou seja, nada. O que se segue é loucura, algo como uma dança cossaca entre as duas casas, durante a qual o cossaco raspa e escava a terra com os saltos das botas até que sob ele sua cova se forma.

Datada do início de 1921, muito provavelmente janeiro ou fevereiro deste ano ${ }^{161}$, e contida no chamado "Caderno do artista da fome" [1921-1922], esta pequena e extraordinária anotação registra, a princípio, o estancamento do último ciclo produtivo do escritor que havia se estendido de agosto a dezembro de 1920 e cujo resultado fora um maço de 51 folhas soltas, chamado pelos críticos de "Konvolut 1920". No entanto, aquilo que se inicia como enunciado autobiográfico logo se move em direção ao imaginário (no exato momento em que o escritor instaura uma comparação: "Daraus will ich mich dann aufbauen so wie einer, dessen Haus unsicher ist, daneben ein sicheres aufbauen will [...]."/"A partir disso eu quero então me construir assim como alguém que tem uma casa insegura e ao lado dela quer construir uma segura [...]."), convertendo-se assim em uma espécie de narrativa. Sublinhe-se para tanto a transição do registro do "eu" autobiográfico para o do "ele", sendo que este "ele" ao final da anotação converter-se-á ainda em "o cossaco".

\footnotetext{
${ }^{160}$ F. Kafka, "Hungerkünstlerheft", em KKA N2, p. 373.

${ }^{161}$ Cf. J. Schillemeit, em F. Kafka, KKA N2 App, p. 111-112.
} 
O miolo imaginário desta anotação me parece particularmente interessante pois expõe de maneira assombrosa e refletida o modo como a forma kafkiana passara também a se conceber e a se construir/destruir a partir do final de 1916. Dito isso, voltemos à anotação. Adentrando-se em seus meandros imaginários, o quadro que logo se descortina é desolador: as forças da figura que havia se lançado na tarefa de construção de uma casa segura para substituir sua antiga casa insegura - e valendo-se do material desta - esgotam-se em meio ao processo de construção; resta então a exaurida personagem, a céu aberto, entre duas construções inacabadas: a semidestruída (a destruição inacabada) e a semiacabada (a construção inacabada).

A anotação porém não se interrompe aqui, pois o quadro que se segue (também de tirar o fôlego) é como o próprio escritor assinala "loucura": sintomaticamente entre (!) as duas casas, a semidestruída e a semiacabada, inicia-se então uma "dança cossaca" ao final da qual o cossaco acabará por "raspar e escavar" a terra até que sob ele sua cova esteja formada.

Sendo assim, não custa destacar que estamos aqui diante de uma dança que se desdobra rumo à destruição; afinal, ela prossegue até que a cova do dançarino (cossaco) esteja pronta, acabada. Nesse sentido, ela é, portanto, uma espécie de dança da morte. ${ }^{162}$ Ao mesmo tempo, porém, não se deve esquecer que ela também é uma dança que ao final constrói a própria cova: "[...] bis sich unter inm sein Grab bildet."/“[...] até que sob ele sua cova se forma". Ou seja, esta dança forma, configura, molda ("bilden"!) sua cova, enfim, sua destruição. ${ }^{163}$ Estas duas dimensões - construção/destruição - não podem portanto ser separadas.

162 Convém sublinhar que tanto a imagem de uma figura a cavar a própria cova quanto a de uma dança da
morte não eram absolutamente novas na produção deste escritor. Em "Um sonho" [1914-1915], a personagem
Josef K. também havia cavado a própria cova. E a se levar em conta o contexto da Primeira Guerra Mundial, o
"esquisito" cemitério que irrompe repentinamente no sonho de K. não parecerá "tão" estranho: atente-se para
o dado de que se trata de um cemitério repleto de bandeiras (que inclusive dificultam a personagem de
enxergar aquele que será o seu próprio túmulo: "Às vezes entretanto ele praticamente não via o túmulo,
subtraído à sua visão por bandeiras cujos panos ondulavam e batiam com muita força uns nos outros [...].") e
no qual parece reinar grande empolgação ("[...] não se avistavam os porta-bandeiras, mas era como se lá
reinasse grande empolgação."). À margem, assinale-se o dado de que a Primeira Guerra foi, por definição,
uma guerra de trincheiras; ou seja, uma guerra na qual os combatentes, a exemplo de K., também cavavam
literalmente as suas próprias covas. O escritor também irá se apropriar desta imagem, mais tarde, em $A$
construção [novembro/dezembro 1923], uma narrativa central do último Kafka: aqui a personagem constrói -
cavando, escavando e socando a terra com a própria testa - sua fortificação subterrânea (e, de certo modo,
também sua cova). Com relação à imagem de uma dança da morte, Kafka havia também oferecido em
Durante a construção da Muralha da China [março 1917] a descrição de um espetáculo ainda mais grandioso,
posto que executado coletivamente, e sem dúvida mais sombrio: na chamada "ciranda do povo" ("Reigen des
Volkes"), o sangue dos seus "dançarinos", como vimos, não fica mais encerrado nos estreitos limites de seus
corpos. Não há portanto como ignorar aqui as ressonâncias do contexto de mobilização e também dos
abatedouros da Primeira Guerra.
163 Também o emprego aqui da figura do cossaco é no mínimo curioso. Não custa lembrar que na Rússia
czarista os cossacos constituíam um povo militarmente organizado e tradicionalmente empregado na guarda 
Isso posto, e avançando um pouco mais, podemos então dizer que entre os dois processos abortados - a suspensão da destruição (casa semidestruída) e a suspensão da construção (casa semiacabada) - instaura-se então um outro processo que conjuga em si mesmo ambas as dimensões dos processos suspensos. Ou seja, este outro processo é, ao mesmo tempo, construção e destruição; afinal, a dança que constrói a própria destruição não é outra coisa senão dança que realiza a sua desaparição. ${ }^{164}$

Diante disso, que a expressão "destruição construtiva”/“destruição que se constrói” ("aufbauende Zerstörung") ${ }^{165}$ tenha sido já moldada por Kafka, alguns anos antes, sintomaticamente no âmbito de seus cadernos in-oitavo não deve pois causar espanto. Estaria já aí, salvo engano, a chave desta nova forma kafkiana: nem construção semidestruída, nem tampouco semiacabada, mas uma forma que se configura, a rigor, no limiar entre a semidestruição e o semiacabamento. ${ }^{166}$ Também não é de se surpreender que poucos meses depois, às portas de outro vigoroso ciclo produtivo, refiro-me ao ciclo produtivo que se inicia no final de janeiro e se estende até agosto de 1922, encontremos nos diários deste escritor a significativa anotação: "Diese ganze Litteratur ist Ansturm gegen die Grenze [...]."/“Esta literatura toda é assalto contra o limite [...]."167

Deste novo ciclo produtivo, aliás, emergirá sintomaticamente a figura do "artista da fome" (em alemão, "Hungerkünstler"), ou seja, de um artista que faz do "passar fome" ("hungern") uma arte ("Hungerkunst": literalmente, "arte da fome" ou "arte de passar fome"). A narrativa intitulada "Um artista da fome" foi escrita em maio de 1922; o simples fato de Kafka ter emprestado o seu título para aquele que viria a ser o seu último livro organizado em vida mostra a importância que o escritor atribuía a ela. Como se sabe, estamos aqui diante de um artista que "não sentia limites [Grenzen]" na execução de sua arte:

das fronteiras, ou seja, dos limites do império. Na anotação kafkiana, contudo, o cossaco - em termos históricos, portanto, um defensor da fronteira, do limite - acaba por se transformar sintomaticamente em figura do limiar, ou seja, figura do entre.

${ }^{164}$ À margem, assinala-se ainda que este processo de construção/destruição não opera, por sua vez, entre dois pólos de contornos bem definidos; mas sim entre dois pólos, também em si, imprecisos, ou seja, o da semidestruição (e não o da destruição total, completa) e o do semiacabamento (e não o do acabamento completo, perfeito).

${ }^{165}$ F. Kafka, "Oktavheft H”, em KKA N2, p. 105.

${ }^{166}$ Para o desdobramento destas minhas reflexões sobre a forma kafkiana, o instigante conceito de "formação supressiva" moldado pelo crítico José Antônio Pasta Jr. no âmbito da literatura brasileira foi de fundamental importância. Aproveito ainda para assinalar o fato das esquisitices da nossa literatura brasileira terem contribuído, não por acaso, para o meu entendimento da produção de Kafka e, em um plano mais amplo, para uma melhor compreensão de uma literatura como a austríaca. Sem dúvida, muito dos avanços da crítica literária austríaca nos últimos anos (com destaque para Wendelin Schmidt-Dengler e Klaus Zeyringer) se devem, penso eu, ao fato desta crítica ter se contraposto a uma tradição que insistia em fazer da literatura austríaca um apêndice da alemã, desprezando assim as suas especificidades e idiossincrasias, que definitivamente não são poucas.

${ }^{167}$ F. Kafka, "Zwölftes Heft" [16.01.1922], em KKA T, p. 878, grifo meu. 
Als Höchstzeit für das Hungern hatte der Impresario vierzig Tage festgesetzt, darüber hinaus ließ er den Künstler niemals hungern [...]. [...]. Warum jetzt gerade nach vierzig Tagen aufhören, er hätte es noch lange, unbeschränkt lange ausgehalten, warum gerade jetzt aufhören, wo er im besten, ja noch nicht einmal im besten Hungern war. Warum wollte man inn des Ruhmes berauben weiterzuhungern, nicht nur der größte Hungerkünstler aller Zeiten zu werden, der er ja wahrscheinlich schon war, aber auch noch sich selbst zu übertreffen bis ins Unbegreifliche, denn für seine Fähigkeit zu hungern fühlte er keine Grenzen. ${ }^{168}$

O empresário havia fixado em quarenta dias o prazo máximo de jejum [Hungern], acima disso ele nunca deixava o artista jejuar [hungern] [...]. [...]. Por que parar justamente agora, depois de quarenta dias? Ele poderia suportar ainda muito tempo, um tempo ilimitado; por que suspender [interromper] agora, quando estava no melhor, isto é, ainda não estava no melhor do jejum [Hungern]? Por que queriam privá-lo da glória de continuar passando fome [weiterhungern], de se tornar não só o maior artista da fome de todos os tempos - coisa que provavelmente já era - mas também de superar a si mesmo até o inconcebível, uma vez que não sentia limites para a sua capacidade de passar fome ${ }^{169}$

\section{É preciso chamar a atenção para o fato de que não se tem aqui apenas um artista que realiza, que constrói a sua obra de arte a partir do próprio corpo (dimensão já presente na própria dança cossaca); mas de um artista que converte o próprio corpo em obra de arte, passando então literalmente a se consumir em sua execução. ${ }^{170}$ A "estranha"}

\footnotetext{
${ }^{168}$ F. Kafka, "Hungerkünstlerheft" [“Ein Hungerkünstler”], em KKA N2, p. 388-389.

${ }^{169}$ F. Kafka, "Um artista da fome", em $A F / C$, p. 26-27 (tradução modificada).

170 Dimensão esta, sem dúvida, também presente no narrador-construtor de $\underline{A \text { construção }}$ [novembro/dezembro 1923], um dos textos centrais do último Kafka:
}

Während alles andere vielleicht mehr eine Arbeit angestrengtesten Verstandes als des Körpers ist, ist dieser BurgPlatz das Ergebnis allerschwerster Arbeit meines Körpers in allen seinen Teilen. Einigemale wollte ich in der Verzweiflung körperlicher Ermüdung von allem ablassen, wälzte mich auf dem Rücken und fluchte dem Bau, schleppte mich hinaus und ließ den Bau offen daliegen [...]. Die Arbeit am Burgplatz erschwerte sich auch unnötig, unnötig will sagen, daß der Bau von der Mehrarbeit keinen eigentlichen Nutzen hatte, dadurch, daß gerade an der Stelle wo der Platz plangemäß sein sollte, die Erde recht locker und sandig war, die Erde mußte dort geradezu festgehämmert werden, um den großen schön gewölbten und gerundeten Platz zu bilden. Für eine solche Arbeit aber habe ich nur die Stirn. Mit der Stirn also bin ich tausend und tausend mal tage- und nächtelang gegen die Erde angerannt, war glücklich wenn ich sie mir blutig schlug, denn dies war ein Beweis der beginnenden Festigung der Wand, und habe mir auf diese Weise, wie man mir vielleicht zugestehen wird, meinen Burgplatz wohl verdient. (F. Kafka, "Bau-Konvolut" [Der Bau], em KKA N2, p. 580-581, grifos meus.)

Ao passo que todo o resto talvez seja mais uma obra do juízo rigoroso que do corpo, esta praca do castelo é resultado do esforço mais sacrificado de todas as partes do meu físico. Algumas vezes, no exaspero do cansaço corporal, eu quis abandonar tudo, rolei de costas no chão e amaldiçoei a construção, arrastei-me para fora e deixei-a aberta. [...]. A faina na praça do castelo também se tornou desnecessariamente mais difícil (no sentido de que a construção não se beneficiou em nada com o trabalho inútil), porque logo no lugar onde, segundo os planos, deveria ficar o burgo, a terra era solta e arenosa e teve de ser literalmente socada para formar a grande peça abobadada e redonda. Para essa obra eu dispunha apenas da testa. Com a testa, então, eu corri de encontro à terra durante dias e noites, milhares de vezes, e fiquei feliz quando o sangue jorrou, pois era uma prova do início da solidificação da parede, e, desse modo,

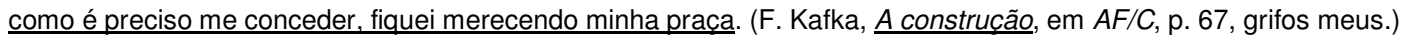


especificidade desta obra de arte é, portanto, a de se constituir a partir de seu definhamento. Em outras palavras, trata-se de uma obra de arte que se realiza, que toma forma, que se corporifica na perda progressiva de sua própria matéria. Próximo ao final da narrativa, aliás, o próprio artista irá sintomaticamente se referir a si mesmo como "um estorvo que se tornava cada vez menor"/“ein immer kleiner werdendes Hindernis"171.

Ao construir se destruindo - ou, em outras palavras, ao trabalhar se destruindo (a expressão "matar-se de trabalhar" diz também muito aqui) - a "esquisita" personagem conquista então a sua propriedade, a sua "praça do burgo" ("Burg-Platz": exatamente desta forma, Kafka grafa a primeira ocorrência da palavra no manuscrito, ou seja, destacando os dois termos do composto) tornando-se com isso o habitante de um burgo (um burguês, portanto). À margem, assinale-se: outro não era o "espetáculo" que se descortinava diariamente aos olhos do escritor no Instituto de Seguros contra Acidentes dos Trabalhadores, a saber, a dimensão destrutiva do trabalho na chamada civilização burguesa. Cf. também:

[...] hier meine Burg ist, die ich durch Kratzen und Beißen, Stampfen und Stoßen dem widerspenstigen Boden abgewonnen habe, meine Burg die auf keine Weise jemandem andern angehören kann und die so sehr mein ist, daß ich hier letzten Endes ruhig von meinem Feind auch die tödliche Verwundung annehmen kann, denn mein Blut versickert hier in meinem Boden und geht nicht verloren.

(F. Kafka, "Bau-Konvolut" [Der Bau], em KKA N2, p. 601, grifo meu)

[...] aqui está o burgo que conquistei ao chão recalcitrante com unhas e dentes, batidas de pé e golpes de cabeça, meu burgo que não pode de modo algum pertencer a qualquer outro e que é tão meu que aqui, afinal, posso calmamente receber do inimigo o ferimento mortal, pois o meu sangue se infiltra neste chão e não se perde. (F. Kafka, A construção, em $A F / C$, p. 83, grifo meu.)

Esta poderosa imagem do sangue do construtor a se infiltrar no chão de sua construção - "e [que] não se perde"! - parece conter em última instância a aspiração máxima desta personagem, o seu "sonho de uma construção absolutamente perfeita" ("Traum eines ganz vollkommenen Baues" [F. Kafka, "Bau-Konvolut" [Der Bau], em KKA N2, p. 599.]): a comunhão perversa de "sujeito" (narrador-construtor) e "objeto" (construção). Ao longo de todo o seu relatório, aliás, o narrador-construtor não faz outra coisa senão enfatizar obsessivamente este seu entrelaçamento à sua construção (em uma "Unidade! Unidade!"):

Mir ist dann, als stehe ich nicht vor meinem Haus, sondern vor mir selbst [...].

(F. Kafka, "Bau-Konvolut" [Der Bau], em KKA N2, p. 591, grifo meu.)

É como se não estivesse diante de minha casa, mas de mim mesmo [...].

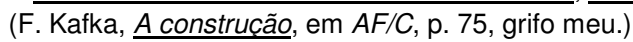

[...] es wäre gar nicht nötig mir durch Überlegungen erst klar zu machen, was mir der Bau bedeutet, ich und der Bau gehören so zusammen [...] nichts kann uns auf die Dauer trennen.

(F. Kafka, "Bau-Konvolut" [Der Bau], em KKA N2, p. 602, grifo meu.)

[...] não seria absolutamente necessário esclarecer, através de ponderações, o que a construção significa para mim: pertencemos um ao outro [...]. [...] nada nos pode separar por muito tempo.

(F. Kafka, A construção, em $A F / C$, p. 83-84, grifo meu.)

Was kümmert mich die Gefahr jetzt, da ich bei Euch [Gänge, Plätze, Burgplatz] bin. Ihr gehört zu mir, ich zu Euch, verbunden sind wir, was kann uns geschehn. (F. Kafka, "Bau-Konvolut" [Der Bau], em KKA N2, p. 605, grifo meu.)

Que me importa o perigo, agora que estou com vocês [corredores, recintos e praça do castelo]! Vocês me pertencem, eu lhes pertenço, estamos ligados, o que pode nos acontecer?"

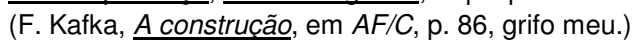

[...] das Glück seines Besitzes hat mich verwöhnt, die Empfindlichkeit des Baues hat mich empfindlich gemacht, $\underline{\text { seine }}$ Verletzungen schmerzen mich als wären es die meinen.

(F. Kafka, "Bau-Konvolut" [Der Bau], em KKA N2, p. 625, grifo meu.)

A felicidade da posse me estragou, $\underline{\text { a vulnerabilidade da construção me tornou vulnerável, os ferimentos dela me }}$

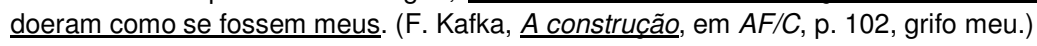

${ }^{171}$ F. Kafka, "Um artista da fome", em $A F / C$, p. 33, grifo meu. 
Enfim, esta é uma arte que, a exemplo da dança cossaca, também progride rumo à destruição e cuja aparição mais acabada significaria literalmente o seu acabamento, ou seja, a sua desaparição. Dito ainda de outro modo, a realização máxima desta arte é já a sua desrealização.

Estamos aqui portanto diante de uma arte que, como apresentada em "O artista da fome" [maio 1922], fala muito de perto ao próprio comportamento da escrita kafkiana a partir da reviravolta formal de 1916/1917: lembre-se para tanto das significativas expressões que virão à tona pouco depois como "destruição construtiva" [1918] ou "assalto contra o limite" [1922]. Também dentro deste contexto, o espantoso comentário de Kafka em carta datada de 1920 de que "não há um destino mais belo para uma narrativa do que desaparecer [...]"172 adquire um alcance extraordinário.

Se os "limites" de uma produção como a de Kafka não se deixam definir ou apreender com facilidade é porque eles vacilam, oscilam, hesitam. "Das Zögern vor dem Geburt."/“A hesitação diante do nascimento." ${ }^{173}$ é, aliás, outra expressiva anotação de Kafka escrita pouco antes daquela sobre o "assalto contra o limite". Não é de se espantar que a poderosa investida desta forma contra o seu próprio limite ("Grenze") - o que parece levá-la, em última instância, a se constituir suspendendo-se (ou a se constituir no limiar entre a semidestruição e o semiacabamento) - acabe por conferir então à produção kafkiana um dinamismo esquisito, criando inclusive inúmeras situações estranhas. Assim, se imaginarmos uma hipotética edição da produção deste autor em apenas dois volumes - um de textos publicados e outro de textos não-publicados ou um de textos "acabados" (ou autônomos) e outro de textos "não-acabados" -, inúmeros textos iriam constar em ambos os volumes: pense-se, por exemplo, em "Diante da lei" ou "Uma mensagem imperial", publicados em vida como narrativas autônomas ("acabadas"), mas enquanto pertencentes, respectivamente, ao romance $O$ processo e à narrativa Durante a construção da Muralha da China, não publicados e inacabados. À primeira vista, a suposição pode parecer ingênua, mas talvez em sua simplicidade ela acabe nos revelando algo mesmo da especificidade desta produção. Que o próprio Kafka tenha escrito tanto e publicado tão pouco em vida, que Brod tenha em sua edição (da "obra completa" de Kafka) acabado por inventar um outro escritor e que, finalmente, mesmo a Edição Crítica deste escritor não tenha conseguido contornar todos os empecilhos colocados por esta produção são testemunhos disso.

\footnotetext{
172 F. Kafka, Briefe an Milena [carta datada de 13.07.1920], p. 108: "Allerdings gibt es kein schöneres Schicksal für eine Geschichte als zu verschwinden [...]."

${ }^{173}$ F. Kafka, "Zwölftes Heft" [24.01.1922], em KKA T, p. 888. Trata-se de uma anotação escrita oito dias após aquela sobre o "assalto contra o limite"!
} 
Isso posto, passemos então a um estudo mais detido do fragmento de drama $\underline{O}$ guarda da tumba e também a um esboço da espantosa constelação de narrativas que se seguem a este texto (Capítulo 2: A velha Monarquia do Danúbio desce aos infernos) e, em seguida, ao estudo da narrativa fragmentária Durante a construção da Muralha da China (Capítulo 3: Reflexões sobre a "China européia"). 


\title{
CAPÍTULO 2 \\ A velha Monarquia do Danúbio desce aos infernos
}

\author{
Something is rotten in the state of Denmark. \\ (William Shakespeare, Hamlet, 1599) ${ }^{174}$ \\ - Vá embora, meu filho, não suporto mais esse odor \\ de inferno!
}

(August Strindberg, Inferno, 1896-1897) ${ }^{175}$

Este capítulo divide-se, por sua vez, em duas partes: em um primeiro momento trabalharemos o fragmento de drama $\underline{O}$ guarda da tumba [novembro/dezembro 1916] e em seguida nossa atenção se volta para o poderoso percurso que vai da escrita de $\underline{O}$ guarda da tumba a Durante a construção da Muralha da China [março 1917] e "Uma folha antiga" [março 1917] - tendo por leitmotiv o que aqui chamaremos de ponto de vista da decomposição - e através do qual o escritor mostra-se às voltas com o processo de decomposição da velha Monarquia do Danúbio em meio à Primeira Guerra Mundial, "o maior teatro do mundo".

Isso posto, e antes de se passar ao estudo de $\underline{O}$ guarda da tumba [novembro/dezembro 1916], faz-se necessário aqui abrir um pequeno parêntese com o objetivo de esboçar em grandes linhas o significativo contexto no qual, dois anos antes da primeira e única incursão dramática de Kafka, se dá em sua produção narrativa a irrupção de uma espécie de temática do teatro; a saber, o contexto do início da Primeira Guerra Mundial:

\begin{abstract}
"Glaubst Du", fragte Karl, "daß auch ich noch eine Stelle bekommen werde?" "Ganz bestimmt", sagte Fanny, "es ist ja das größte Teater der Welt." [...]. "Ist denn das Ganze wirklich so groß" fragte Karl. "Es ist das größte Teater der Welt", sagte Fanny nochmals, "ich habe es allerdings selbst noch nicht gesehn, aber manche meiner Kolleginnen, die schon in Oklahama waren, sagen, es sei fast grenzenlos." "Es melden sich aber wenig Leute", sagte Karl [...]. "Das ist wahr", sagte Fanny. "Bedenke aber, daß wir in allen Städten Leute aufnehmen, daß unsere Werbetruppe immerfort
\end{abstract}

\footnotetext{
${ }^{174}$ W. Shakespeare, Hamlet, p. 215 [Act 1, Scene 4]. Trad. de Millôr Fernandes (W. Shakespeare, Hamlet, p. 35 [Ato 1, Cena 4]): "Algo está podre no Estado da Dinamarca."

${ }^{175}$ A. Strindberg, "O inferno desencadeado", em Inferno (Trad. de Ismael Cardim), p. 193.
} 
reist und daß es noch viele solche Truppen gibt." "Ist denn das Teater noch nicht eröffnet?" fragte Karl. "Oja”, sagte Fanny, "es ist ein altes Teater, aber es wird immerfort vergrößert."176

- Você acha - perguntou Karl - que eu também vou conseguir um emprego?

- Com toda certeza - disse Fanny -, pois é o maior teatro do mundo. [...].

- Será que realmente é tudo tão grande assim? - perguntou Karl.

- É o maior teatro do mundo - disse Fanny de novo -, é verdade que eu mesma ainda não o vi, mas algumas das minhas colegas que já estiveram em Oklahama dizem que ele é quase sem limites.

- Mas pouca gente se candidata - disse Karl [...].

- Isso é verdade - disse Fanny -, mas pense que nós admitimos pessoas em todas as cidades, que a nossa trupe/tropa de recrutamento viaja continuamente e que ainda há muito mais trupes/tropas como essas.

- Mas o teatro ainda não foi aberto? - perguntou Karl.

- Claro que foi - disse Fanny -, é um velho teatro, mas ele vem sendo constantemente ampliado. ${ }^{177}$

Em um belo ensaio intitulado "Kafka, a guerra e o maior teatro do mundo"178 e datado de 1996, o crítico Thomas Anz chama a atenção para o fato de que até aquela data a crítica kafkiana havia se limitado quase que exclusivamente a indicar as concordâncias do fragmento "Karl viu na esquina de uma rua [...]" [outubro 1914] com o relato de viagem do jornalista e escritor Arthur Holitscher pelos Estados Unidos, Amerika heute und morgen, a principal fonte utilizada por Kafka para a escrita de $O$ desaparecido. Escrito, simultaneamente à narrativa Na colônia penal, ao longo de duas semanas em outubro de 1914 e em meio a uma interrupção do trabalho em O processo, o fragmento "Karl viu na esquina de uma rua [...]" foi erroneamente tomado por Max Brod como capítulo final do romance $O$ desaparecido e publicado com o título de "O teatro natural de Oklahoma", outra invenção do amigo de Kafka. Já o popular relato de viagem de Holitscher pelos Estados Unidos foi originalmente publicado entre o final de 1911 e o início de 1912 na revista Neue Rundschau da qual Kafka era leitor assíduo (não por acidente, a data coincide com o aparecimento de uma primeira versão, destruída, de $O$ desaparecido) e

\footnotetext{
${ }^{176}$ Cf. F. Kafka, "Karl sah an einer Straßenecke [...]", em KKA V, p. 394.

${ }^{177}$ F. Kafka, "Kafka viu na esquina de uma rua [...]", em O desaparecido, trad. de Susana Kampff Lages, p. 252 (tradução modificada). O vocábulo alemão "Truppe" pode significar tanto trupe (ou seja, uma companhia de teatro) quanto tropa militar; infelizmente não há como vertê-lo para o português sem abrir mão de uma destas acepções. A tradutora brasileira optou por "trupe" que é, neste caso, a acepção, obviamente, mais evidente. Como aqui interessa-me sublinhar as fortes ressonâncias militares deste texto, optarei por manter na tradução, lado a lado, as duas acepções de "Truppe"; ou seja, "trupe/tropa".

${ }^{178} \mathrm{O}$ ensaio "Kafka, der Krieg und das Größte Theater der Welt" de Thomas Anz foi primeiramente publicado em 1996 na Revista Neue Rundschau. Uma versão ampliada deste ensaio sairia publicada em 2000 no livro organizado por Uwe Schneider e Andreas Schumann "Krieg der Geister": Erster Weltkrieg und literarische Moderne.
} 
pouco depois na forma de livro (Kafka inclusive dispunha em sua biblioteca pessoal de um exemplar da $7^{a}$ edição, datado ainda de 1913 [!], o que portanto dá uma idéia da popularidade do relato de Holitscher). E, de fato, as concordâncias entre os textos são explícitas: desde grafias "equivocadas" de topônimos como New York e Oklahoma seguindo a grafia empregada por Holitscher, Kafka também escreve "Newyork" e "Oklahama", "erros" corrigidos por Max Brod em sua primeira edição do romance kafkiano em 1927 - a motivos e formulações tomados quase literalmente. Para tanto basta comparar a abertura do texto kafkiano:

Karl sah an einer Straßenecke ein Plakat mit folgender Aufschrift: "Auf dem Rennplatz in Clayton wird heute von sechs Uhr früh bis Mitternacht Personal für das Teater in Oklahama aufgenommen! Das große Teater von Oklahama ruft Euch! Es ruft nur heute, nur einmal! Wer jetzt die Gelegenheit versäumt, versäumt sie für immer! Wer an seine Zukunft denkt, gehört zu uns! Jeder ist willkommen! Wer Künstler werden will melde sich! Wir sind das Teater, das jeden brauchen kann, jeden an seinem Ort! Wer sich für uns entschieden hat, den beglückwünschen wir gleich hier! Aber beeilt Euch, damit Ihr bis Mitternacht vorgelassen werdet! Um zwölf wird alles geschlossen und nicht mehr geöffnet! Verflucht sei wer uns nicht glaubt! Auf nach Clayton!" [...]. Für Karl stand aber doch in dem Plakat eine große Verlockung. "Jeder war willkommen", hieß es. Jeder, also auch Karl. Alles was er bisher getan hatte, war vergessen, niemand wollte inm daraus einen Vorwurf machen. Er durfte sich zu einer Arbeit melden, die keine Schande war, zu der man vielmehr öffentlich einladen konnte! [...]. Karl las das Plakat nicht zum zweitenmale, suchte aber noch einmal den Satz: "Jeder ist willkommen" hervor. ${ }^{179}$

Karl viu na esquina de uma rua um cartaz com os seguintes dizeres: "Hoje no hipódromo de Clayton, das seis da manhã à meia-noite, contratam-se pessoas para o Theatro de Oklahama! O grande Theatro de Oklahama vos chama! E chama só hoje, só uma vez! Quem perder a oportunidade de agora, a perderá para sempre! Quem pensa no futuro nos pertence! Todos são bem-vindos [Jeder ist willkommen]! Quem quiser ser artista, apresente-se! Somos um teatro que pode aproveitar a todos, cada qual em seu lugar! Quem decidir juntar-se a nós receba aqui as nossas felicitações! Mas, apressem-se, para serem atendidos até a meia-noite! Às doze tudo será fechado e não reabrirá mais! Maldito seja aquele que não acredita em nós! Avante, para Clayton!" [...]. Para Karl, porém, havia um grande atrativo no cartaz: "Todos são bem-vindos" [Jeder war willkommen], era o que constava. Todos, portanto também Karl. Tudo o que ele tinha feito até então fora esquecido, ninguém pretendia the reprovar nada. Ele podia se apresentar para um trabalho que não era indecoroso, pelo contrário, um trabalho para o qual chegavam a convidar em público! [...]. Karl

\footnotetext{
${ }^{179}$ F. Kafka, "Karl sah an einer Straßenecke [...]", em KKA V, p. 387-388.
} 
não leu uma segunda vez o cartaz, mas mais uma vez procurou pela frase: "Todos são bem-vindos" [Jeder ist willkommen]. ${ }^{180}$

com o relato que Holitscher faz dos grandes cartazes nas esquinas das ruas de Toronto com dizeres como "50.000 lavradores imediatamente para o oeste!" ou "Precisa-se de 30.000 colheiteiros para Manitoba!"181 ou de um parque nas imediações de Chicago sobre o qual "tudo o que o senhor vê aqui está livre e irrestritamente à disposição do povo de Chicago. Qualquer um é bem-vindo [Jeder ist wilkommen]. Ele pode falar qualquer língua. Ele pode carregar sobre o corpo os farrapos mais miseráveis e cheios de insetos [Ungeziefer]. Ele pode vir de qualquer lugar. Ele não precisa apresentar nenhum documento, não precisa escrever seu nome em nenhum livro - nem o verdadeiro, nem o falso. Qualquer um é bem-vindo [Jeder ist willkommen], nós vivemos por aqui em um país democrático."182 Também espantoso é se deparar no livro de Holitscher com uma fotografia com a irônica legenda "Idyll aus Oklahama" ("Idílio de Oklahama”) que exibe um grupo de brancos que posam satisfeitos e orgulhosos ao lado de um negro enforcado em uma árvore; afinal, diante de um tal "idílio" e tendo também em vista o nome "singelamente" informado por Karl Roßmann durante o processo de recrutamento, fica difícil não atribuir cores ainda mais sombrias ao "Grande Teatro de Oklahama"183.

Es gab aber noch eine kleine Verzögerung, als man inn jetzt nach seinem Namen fragte. Er antwortete nicht gleich, er hatte eine Scheu, seinen wirklichen Namen zu nennen und aufschreiben zu lassen. Bis er hier auch nur die kleinste Stelle erhalten und zur Zufriedenheit ausfüllen würde, dann mochte man seinen Namen erfahren, jetzt aber nicht, allzulang hatte er inn verschwiegen, als daß er inn jetzt hätte verraten sollen. Er nannte daher, da inm im Augenblick kein anderer Name einfiel, nur den Rufnamen aus seinen letzten Stellungen: "Negro". "Negro?" fragte der Leiter, drehte den Kopf und machte eine Grimasse, als hätte Karl jetzt den Höhepunkt der Unglaubwürdigkeit erreicht. Auch der Schreiber sah Karl eine Weile prüfend an, dann aber wiederholte er "Negro" und schrieb den Namen ein. "Sie haben doch nicht Negro aufgeschrieben", fuhr inn der Leiter an. "Ja, Negro", sagte der Schreiber ruhig und machte eine Handbewegung, als habe nun der Leiter das Weitere zu veranlassen. Der Leiter bezwang sich auch, stand auf und sagte: "Sie sind also für das Teater von

\footnotetext{
${ }^{180}$ F. Kafka, "Kafka viu na esquina de uma rua [...]", em O desaparecido, p. 247-248.

${ }^{181}$ A. Holitscher apud T. Anz, "Kafka, der Krieg und das größte Theater der Welt", em U. Schneider e A. Schumann (orgs.), "Krieg der Geister", p. 253.

${ }^{182}$ A. Holitscher apud T. Anz, "Kafka, der Krieg und das größte Theater der Welt", em U. Schneider e A. Schumann (orgs.), "Krieg der Geister", p. 254.

${ }^{183}$ Este "cenário" tenebroso será inclusive confirmado por uma futura anotação de Kafka, datada de setembro de 1915, em que o escritor sinaliza o triste destino do protagonista de O desaparecido: "Roßmann und K., der Schuldlose und der Schuldige, schließlich beide unterschiedslos strafweise umgebracht, der Schuldlose mit leichterer Hand, mehr zur Seite geschoben als niedergeschlagen." (F. Kafka, "Elftes Heft" [30/09/1915], KKA T, p. 757: "Roßmann e K., o inocente e o culpado, ambos finalmente assassinados, sem distinção; o inocente de forma mais leve, mais posto de lado do que abatido.")
} 
Oklahama -". Aber weiter kam er nicht, er konnte nichts gegen sein Gewissen tun, setzte sich und sagte: "Er heißt nicht Negro." Der Schreiber zog die Augenbrauen in die Höhe, stand nun selbst auf und sagte: "Dann teile also ich Ihnen mit, daß Sie für das Teater in Oklahama aufgenommen sind und daß man Sie jetzt unserm Führer vorstellen wird." 184

Entretanto houve mais uma certa demora quando perguntaram pelo seu nome. Ele não respondeu de imediato, tinha certo temor de dizer seu verdadeiro nome para ser registrado. Depois de conseguir nem que fosse o posto mais ínfimo e cumprir suas tarefas a contento, aí então poderiam ficar sabendo do seu nome, mas não naquele momento; ele o havia omitido por um tempo longo demais para acabar por revelá-lo ali agora. Disse, portanto, já que no momento não lhe ocorria nenhum outro nome, apenas o nome pelo qual vinha sendo chamado nos seus últimos locais de trabalho:

- Negro.

- Negro? - disse o chefe [Leiter], girou a cabeça e fez uma careta, como se dizendo aquilo Karl tivesse chegado ao cúmulo da falta de credibilidade. O escrevente também olhou para Karl por um instante com ar interrogativo mas depois repetiu:

- Negro - e registrou o nome.

- Não é que escreveu "Negro"?! - interpelou o chefe [Leiter].

- Escrevi: Negro - disse o escrevente calmamente e fez um gesto com a mão como se o restante estivesse a cargo do chefe [Leiter].

Este fez um esforço para se dominar, ergueu-se e disse:

- Para os efeitos do Theatro de Oklahama você é - mas ele não conseguiu continuar falando, não podia agir contra a sua consciência; sentou-se e disse: - Ele não se chama Negro.

O escrevente ergueu as sobrancelhas, levantou-se igualmente e disse:

- Pois então, eu Ihe comunico que foi admitido no Theatro de Oklahama e que agora será apresentado ao nosso chefe [Führer: comandante] ${ }^{185}$

Voltando ao ensaio de Anz, o crítico então assinala que as flagrantes similitudes entre os textos de Holitscher e Kafka haviam, contudo, ofuscado a crítica kafkiana para uma outra concordância também brutal, a saber, as afinidades entre o processo de recrutamento para o "Grande Teatro de Oklahama" e o cenário de mobilização do início da Primeira Guerra Mundial. Afinal, "é notável a insistência com a qual neste capítulo do romance Kafka se vale da palavra 'Truppe' [tropa/trupe]. E embora ela seja apenas uma abreviatura da palavra 'Werbetruppe' [tropa/trupe de recrutamento], freqüentemente também empregada, e se refira igualmente a uma trupe de teatro [Theatertruppe], não é despropositado lê-la também na acepção militar."186

\footnotetext{
${ }^{184}$ F. Kafka, "Karl sah an einer Straßenecke [...]", em KKA V, p. 402-403.

${ }^{185}$ F. Kafka, F. Kafka, "Kafka viu na esquina de uma rua [...]", em O desaparecido, p. 257-258.

${ }^{186}$ T. Anz, "Kafka, der Krieg und das größte Theater der Welt", em U. Schneider e A. Schumann (orgs.), "Krieg der Geister”, p. 252. Cf. também p. 257: "Que a descrição do 'Teatro de Oklahama' dificilmente pode ser lida como retrato de um teatro real, disso o próprio texto já se encarrega através de suas muitas
} 
Em seguida, Anz passa então a ressaltar este cenário de mobilização em uma série de artigos publicados logo no início da Primeira Guerra em dois dos principais jornais de Praga - Prager Tagblatt e Bohemia -, chamando a atenção para a posição estratégica que o teatro passava a assumir neste contexto "dramático". E isso não apenas no quadro das reportagens de guerra. Para tanto lembre-se que a própria propaganda de guerra austro-húngara chega a se servir em setembro e outubro de 1914 de um cartão postal impresso na forma de um cartaz de teatro fictício no qual um "Teatro mundial europeu" (“Europäisches Welt-Theater”) apresenta "de hoje em diante até novo aviso" a peça intitulada "A Guerra Mundial ou quem ri por último ri melhor"; entre as personagens contam-se: "Lorde Inglaterra, grande capitão de ladrões", "Senhorita França, sua amante", "Cossaco Rússia, assassino profissional e ladrão de terras", "Sérvia, assassino de rei e atirador de bombas", "Japão, um macaco amarelo" etc. ${ }^{187}$ Por fim, Anz lembra ainda que Oskar Bie, o redator da Neue Rundschau, também se valeu explicitamente - em pelo menos dois textos desta revista, um publicado em setembro e o outro em outubro - do

inverossimilhanças." Em adição a este comentário de Anz, chamo a atenção para o fato de que o próprio protagonista não deixa de sublinhar, em inúmeras ocasiões, estes "ruídos" inverossímeis:

"Es ist gut”, sagte dann der Personalchef [...], "die Papiere werden jetzt in den Aufnahmskanzleien überprüft werden. Wie Sie schon aus unserm Plakat gesehn haben, können wir jeden brauchen. Wir müssen aber natürlich wissen, was für einen Beruf er bisher ausgeübt hat, damit wir ihn an den richtigen Ort stellen können, wo er seine Kenntnisse verwerten kann." "Es ist ja ein Teater", dachte Karl zweifelnd und hörte sehr aufmerksam zu.

(F. Kafka, "Karl sah an einer Straßenecke [...]", em KKA V, p. 398, grifos meus.)

- Está bem - disse então o chefe do setor de pessoal [...] -, os documentos serão verificados nos gabinetes de admissão. Como já viram no nosso cartaz, podemos aproveitar a todos. É claro que precisamos saber que profissão cada um exerceu até agora, para que possamos empregá-lo no lugar certo, onde ele possa aplicar seus conhecimentos.

"Mas é um teatro!", pensou Karl cheio de dúvida e seguiu prestando muita atenção.

(F. Kafka, "Kafka viu na esquina de uma rua [...]", em O desaparecido, p. 255, grifos meus.)

"Zu was für einem Posten fühlen Sie sich geeignet?" Diese Frage enthielt möglicherweise wirklich eine Falle, denn wozu wurde sie gestellt, da Karl doch schon als Schauspieler aufgenommen war [...]. [...]. "Sind Sie denn kräftig genug für schwerere Arbeit?" fragte der Herr. "Oja", sagte Karl. Hierauf ließ der Herr Karl näher zu sich herankommen und befühlte seinen Arm. "Es ist ein kräftiger Junge", sagte er dann, indem er Karl am Arm zum Führer hinzog. Der Führer nickte lächelnd, reichte ohne sich übrigens aus seiner Ruhelage aufzurichten Karl die Hand und sagte: "Dann sind wir also fertig. In Oklahama wird alles noch überprüft werden. Machen Sie unserer Werbetruppe Ehre!" (F. Kafka, "Karl sah an einer Straßenecke [...]", em KKA V, p. 407-409, grifos meus.)

- Para que cargo se considera apto?

Era possível que houvesse uma armadilha nessa pergunta, pois com que propósito teria sido ela formulada, se Karl já fora admitido como ator? [...]

-É forte o suficiente para o trabalho pesado? - perguntou o homem.

- Sou, sim! - exclamou Karl.

A seguir mandou que Karl se aproximasse e apalpou-lhe o braço.

- É um jovem robusto - disse ele então, puxando Karl pelo braço até o chefe [Führer: comandante].

$O$ chefe [Führer: comandante] assentiu sorrindo, estendeu a mão para Karl sem se erguer de sua posição recostada e disse:

- Então terminamos. Em Oklahama tudo será verificado novamente. Honre a nossa trupe/tropa de recrutamento!

(F. Kafka, "Kafka viu na esquina de uma rua [...]", em O desaparecido, p. 261-262, grifos meus.)

187 Cf. H. Weigel et al. (orgs.), Jeder Schuss ein Russ, Jeder Stoss ein Franzos: literarische und graphische Kriegspropaganda in Deutschland und Österreich 1914-1918, p. 104. 
termo "teatro da guerra" ("Kriegstheater"); e que também Anton Kuh, um conhecido de Kafka, havia publicado em 11 de agosto de 1914 no jornal Prager Tagblatt um comentário sobre a guerra que se iniciava com a sintomática frase: "Ein Traumtheater ist die Welt geworden"188 ("O mundo transformou-se em um teatro do sonho").

É, no entanto, curioso que Anz não tenha se dado conta de que a irrupção desta temática do teatro na produção kafkiana ocorre, a rigor, pouco mais de um mês antes da escrita do fragmento sobre o "Teatro de Oklahama", refiro-me ao capítulo final de $O$ processo, em particular à significativa conversa travada entre Josef $\mathrm{K}$. e os senhores encarregados de sua execução:

\footnotetext{
"Sie sind also für mich bestimmt?" fragte er [Josef K.]. Die Herren nickten, einer zeigte mit dem Cylinderhut in der Hand auf den andern. [...]. "Alte untergeordnete Schauspieler schickt man um mich", sagte sich K. und sah sich um, um sich nochmals davon zu überzeugen. "Man sucht auf billige Weise mit mir fertig zu werden." K. wendete sich plötzlich innen zu und fragte: "An welchem Teater spielen Sie." "Teater?" fragte der eine Herr mit zuckenden Mundwinkeln den andern um Rat. Der andere geberdete sich wie ein Stummer, der mit dem widerspenstigen Organismus kämpft. ${ }^{189}$

- Então os senhores é que me foram destinados? - perguntou [Josef K.].

Os senhores acenaram com a cabeça, um apontou para o outro com a cartola na mão. [...].

"Mandam atores velhos e subalternos me buscar", disse K. consigo mesmo e olhou em volta para se convencer disso. "Procuram acabar comigo de forma barata."

K. voltou-se de repente para eles e perguntou:

- Em que teatro os senhores trabalham?

- Teatro? - perguntou um dos senhores, consultando o outro com uma contorção dos cantos da boca.

O outro se comportava como um mudo que luta com o organismo refratário. ${ }^{190}$
}

Como se sabe, o último capítulo de O processo foi escrito imediatamente após o primeiro, podendo assim ser datado com relativa segurança entre o final de agosto e o início de setembro de 1914; lembre-se ainda que Kafka havia iniciado a escrita de O processo logo após a eclosão da Primeira Guerra Mundial. Dito isso, passemos então à incursão propriamente "dramática" de Kafka.

\footnotetext{
${ }^{188}$ A. Kuh apud T. Anz, "Kafka, der Krieg und das größte Theater der Welt", em U. Schneider e A. Schumann (orgs.), "Krieg der Geister", p. 258.

${ }^{189}$ F. Kafka, KKA P, p. 305-306.

${ }^{190}$ F. Kafka, O processo, p. 272-273.
} 


\section{PARTE 1:}

\section{Estudo sobre o fragmento de drama 0 quarda da tumba}

[...] den Vorhang zu heben und die Wunde zu zeigen.

(Franz Kafka, "Oktavheft F", 1917) ${ }^{191}$

[...] der Teufel steckt nicht mehr im Detail, sondern im Ganzen [...]. Nichts ist, im negativen Sinn, fragmentarischer als ein geschlossenes perfektes Stück. (Heiner Müller, 1987) $^{192}$

\section{O estatuto do texto}

O guarda da tumba, a única incursão dramática de Kafka, foi escrito entre o final de novembro e meados de dezembro de 1916 e ocupa quase por completo o chamado "Caderno in-oitavo 1". É precisamente com a escrita deste caderno in-oitavo que, como vimos, Kafka interrompe um longo período de esterilidade criativa que havia se estendido por quase dois anos, ou seja, desde o abandono do trabalho em $O$ processo no final de janeiro de 1915.

Por se tratar de um dos textos mais fragmentados, riscados e corrigidos deste escritor, o primeiro desafio que O guarda da tumba coloca a seus críticos é certamente o de se haver com o seu intrincado processo de escrita. Assim sendo, e com o objetivo de auxiliar a visualização do leitor, vale a pena esboçar um esquema das 74 páginas que compõem este primeiro caderno in-oitavo e ao longo das quais o drama kafkiano se distribui:

\begin{tabular}{|c|c|l|}
\hline Página & Conteúdo & \multicolumn{1}{c|}{ Comentário } \\
\hline 1 & "Sonho inquebrantável" & Fragmento de narrativa \\
\hline $1-2$ & "Sonho dilacerado" & Fragmento de narrativa (primeira aparição do motivo do guarda da tumba) \\
\hline $3-18$ & $\underline{\text { O guarda da tumba }}$ & $\begin{array}{l}\text { "Primeiro bloco dramático" (16 páginas ao todo, destas 13 estão riscadas): } \\
\text { das 16 páginas que o constituem, as últimas 13 serão riscadas por Kafka; ou } \\
\text { seja, quando da retomada do trabalho neste drama (cf. "segundo bloco } \\
\text { dramático"), o escritor manterá apenas as 3 primeiras páginas. }\end{array}$ \\
\hline $18-21$ & "Narrativa do avô" & $\begin{array}{l}\text { Fragmento de narrativa (segunda tentativa de trabalhar o motivo do guarda } \\
\text { da tumba em âmbito narrativo) }\end{array}$ \\
\hline
\end{tabular}

${ }^{191}$ F. Kafka, "Oktavheft F", em KKA N1, p. 424: "[...] levantar a cortina e expor a ferida."

192 H. Müller apud W. Thierse, 'Das Ganze aber ist das, was Anfang, Mitte und Ende hat.' Problemgeschichtliche Beobachtungen zur Geschichte des Werkbegriffs", em K. Barck et al. (orgs.), Ästhetische Grundbegriffe, p. 384: "[...] o diabo não mais se esconde no detalhe, mas no todo [...]. Nada é, em sentido negativo, mais fragmentário do que uma peça fechada e perfeita." 


\begin{tabular}{|c|c|c|}
\hline $21-25$ & "No sótão" & Fragmento de narrativa \\
\hline $25-31$ & $\begin{array}{c}\text { "A discórdia que } \\
\text { sempre existiu [...]" }\end{array}$ & Fragmento de narrativa sem título \\
\hline $31-74$ & O quarda da tumba & $\begin{array}{l}\text { "Segundo bloco dramático" (44 páginas ao todo, destas cerca de } 17 \text { estão } \\
\text { riscadas): Kafka continua a escrita do drama a partir do ponto em que o } \\
\text { bloco dramático anterior havia sido riscado. } \\
\text { - Kafka escreve então cerca de } 34 \text { páginas e mais uma vez suspende a } \\
\text { escrita do drama: destas novas } 34 \text { páginas, Kafka riscará as últimas } 10 \text {. } \\
\text { - Seguem-se então três tentativas relativamente curtas de continuação deste } \\
\text { bloco dramático a partir do ponto em que o escritor o havia riscado: a } 1^{\text {a }} \\
\text { tentativa estende-se por pouco mais de uma página, sendo então riscada; a } \\
2^{\text {a }} \text { tentativa será um pouco mais longa (cerca de } 6 \text { páginas) mas também } \\
\text { será interrompida e riscada; e a } 3^{a} \text { tentativa estende-se até o final do } \\
\text { caderno (pouco mais de } 2 \text { páginas). }\end{array}$ \\
\hline
\end{tabular}

Em vista deste esquema, note-se que, a rigor, a retomada do trabalho literário após a crise criativa de quase dois anos se faz ainda a partir de dois pequenos fragmentos narrativos para só então dar lugar à forma dramática: o primeiro deles, intitulado "Sonho inquebrantável" [novembro 1916], é abandonado após poucas linhas e seguido então pelo fragmento "Sonho dilacerado" [novembro 1916] que, a seu turno, será também abandonado após pouco mais de uma página. Por conter a primeira aparição do motivo do guarda da tumba, a partir do qual o drama kafkiano irá se desdobrar, não custa transcrever aqui este último fragmento:

\section{Zerrissener Traum}

Die Laune eines früheren Fürsten hatte bestimmt, das Mausoleum müsse unmittelbar bei den Sarkophagen einen Wächter haben. Vernünftige Männer hatten sich dagegen ausgesprochen, schließlich ließ man den sonst vielfach beengten Fürsten in dieser Kleinigkeit gewähren. Ein Invalide aus einem Krieg des vorigen Jahrhunderts, Witwer und Vater dreier Söhne, die im letzten Krieg gefallen waren, meldete sich für den Posten. Er wurde angenommen und von einem alten Hofbeamten in das Mausoleum begleitet. Eine Waschfrau folgte innen beladen mit verschiedenen Dingen, welche für den Wächter bestimmt waren. Bis zur Allee, welche dann geradeaus zum Mausoleum führte, hielt der Invalide trotz seiner Stelze mit dem Hofbeamten gleichen Schritt. Dann aber versagte er ein wenig, hüstelte und begann sein linkes Bein zu reiben. "Nun Friedrich", sagte der Hofbeamte der mit der Waschfrau ein Stück vorausgegangen war und sich nun umsah. "Mich reißt es im Bein", sagte der Invalide und machte eine Fratze, "nur einen Augenblick Geduld, das pflegt gleich aufzuhören." ${ }^{193}$

${ }^{193}$ F. Kafka, "Oktavheft A" ["Zerrissener Traum"], em KKA N1, p. 267-268. Como já indicado no capítulo anterior, o crítico Roland Reuß chama a atenção para o dado de que a semântica do substantivo "Stelze" oscila entre apoio material ("stützendes Hilfsmittel") e prótese ("Prothese"): "Die Rede von der 'Stelze' kann demnach auf eine Amputation hindeuten, sie muß es aber nicht." ("Die ersten beiden Oxforder Oktavhefte 


\section{Sonho dilacerado}

O capricho de um antigo príncipe havia determinado: o mausoléu deveria ter um guarda imediatamente junto aos sarcófagos. Homens racionais haviam se manifestado contrários; por fim consentiu-se esta ninharia ao, em muitos aspectos, limitado príncipe. Um inválido de uma guerra do século passado, viúvo e pai de três filhos que haviam tombado na última guerra, apresentou-se ao posto. Ele foi aceito e acompanhado por um velho funcionário da corte ao mausoléu. Uma faxineira os seguia carregada com inúmeras coisas que eram destinadas ao guarda. Até a alameda, que conduzia então em linha reta ao mausoléu, o inválido manteve, apesar de sua muleta, o mesmo passo do funcionário da corte. Mas então ele vacilou um pouco, pigarreou e começou a coçar a sua perna esquerda. "Então, Friedrich" disse o funcionário da corte que com a faxineira havia se adiantado um trecho e olhava então à sua volta. "Minha perna está latejando de dor", disse o inválido e fez uma careta, "um instante apenas de paciência, isto costuma parar logo."

Por hora, atente-se para o dado de que neste fragmento o guarda da tumba é descrito como "um inválido de uma guerra do século passado, viúvo e pai de três filhos, que haviam tombado na última guerra" e que seu nome é Friedrich. Trata-se portanto de uma vida destroçada por guerras. Afinal ele se tornara inválido em uma guerra do século passado ${ }^{194}$ e perdera seus três filhos na última delas. Também seu nome, no contexto histórico da Monarquia do Danúbio, não poderia aliás ser mais irônico, pois o Arquiduque

Franz Kafkas: eine Einführung", em Franz Kafka-Heft 5, HKKA 01/2, p. 16). Optei por traduzir "Stelze" por "muleta", a outra possibilidade - que não deve ser descartada - seria então "perna de pau" (neste caso a amputação de uma da pernas ou de parte dela estaria pressuposto).

194 À margem, assinale-se ainda que a esta altura - ou seja, final de novembro de 1916 - Kafka era um dos principais funcionários do Instituto de Seguros contra Acidentes dos Trabalhadores na recém-criada seção encarregada dos inválidos de guerra. Como se sabe, pouco após o seu ingresso neste instituto, em 1908, Kafka foi designado para o trabalho de fiscalização dos estabelecimentos industriais e também de extração mineral (por exemplo, o trabalho em pedreiras, minas etc) localizados no norte da Boêmia; nada menos que uma das regiões mais industrializadas de toda Europa e a mais industrializada da Áustria-Hungria (para se ter uma idéia, na virada do século XIX para o XX, somente a Boêmia respondia por $75 \%$ da produção industrial de todo o império). Uma de suas atribuições consistia à época em empreender viagens de inspeção pelo norte da Boêmia com o objetivo de classificar seus estabelecimentos segundo o risco a que seus trabalhadores estavam expostos (quanto piores as condições para os trabalhadores, maiores os riscos de se acidentarem e, portanto, maiores os valores que os estabelecimentos deveriam pagar). Assim, nestas "inocentes" viagens pelos confins do norte da Boêmia, o funcionário Franz Kafka logo haveria de travar contato direto com as péssimas condições de trabalho nestes estabelecimentos e, evidentemente, com o triste destino de muitos destes trabalhadores em seus "combates" diários com monstruosas máquinas. Entretanto, poucos meses após o início da Primeira Guerra, mais precisamente no início de 1915, Kafka foi remanejado para a recémcriada seção do instituto que ficaria encarregada em tempos de guerra não apenas do tratamento dos combatentes "danificados" pelo conflito, mas também de sua recolocação profissional. Cf., por exemplo, o texto escrito por Kafka (assinado, porém, pelo inspetor-chefe do Instituto Eugen Pfohl) e publicado no jornal Rumburger Zeitung em 08.10.1916 "Um grande plano da assistência social de guerra exige realização. Fundação de um hospital psiquiátrico público na Boêmia alemã (em KKA AS, p. 494-498); mas também o apelo escrito por Kafka e publicado no jornal Prager Tagblatt em 16.12.1916 "Ajudem aos inválidos de guerra! Um apelo urgente à população." (em KKA AS, p. 506-513). 
Friedrich von Österreich havia sido escolhido pelo imperador Francisco José para assumir o posto de "Armeeoberkommandant", ou seja, comandante supremo do exército austrohúngaro, deixado vago pela morte em 1914 do Arquiduque Franz Ferdinand (cujo assassinato haveria, por sua vez, de desencadear a Primeira Guerra Mundial). ${ }^{195}$ Como veremos, no drama kafkiano a referência ao guarda da tumba como inválido de guerra será apagada e o nome Friedrich passará a denominar tanto o parque onde se localiza o mausoléu e, conseqüentemente, a tumba dos ancestrais do imperador quanto o nome do duque defunto que encabeça os "senhores da tumba" nas infinitas tentativas noturnas de se evadiram do parque, protegido pelo guarda da tumba.

Imediatamente após "levantar a cortina e expor a ferida [da guerra]" em "Sonho dilacerado", Kafka lançava-se, de fato, à escrita de um drama! Inicialmente, Kafka redige cerca de dezesseis páginas deste seu drama ("primeiro bloco dramático"), suspende sua escrita e volta-se mais uma vez à forma épica; seguem-se então três fragmentos narrativos que também serão abandonados após poucas páginas: "Narrativa do avô", "No sótão" e "A discórdia que sempre existiu entre Hans e seu pai [...]". Kafka então retorna ao seu drama: das dezesseis páginas do "primeiro bloco dramático", o escritor mantém apenas as três primeiras e prossegue a partir deste ponto a escrita do drama que se estenderá então até o final deste caderno ("segundo bloco dramático"). Que todo o trecho riscado do "primeiro bloco dramático" será com efeito desconsiderado por Kafka dá testemunho a existência de uma cópia datilografada (provavelmente do final de dezembro de 1916), infelizmente também fragmentária.

Dito isso, já podemos então esboçar a ação deste fragmento de drama que se desenrola por inteira em um gabinete do palácio do jovem príncipe Leo, que está no poder há menos de um ano (atente-se portanto desde já para o quadro de transição política). A peça inicia-se com um diálogo entre o jovem príncipe e seu camareiro: eles discutem a intenção do príncipe de empregar um segundo guarda na vigilância do mausoléu de sua família que se situa no Parque Friedrich. O camareiro mostra-se contrário à iniciativa com o argumento de que "deve-se deixar os mortos em paz" ("Man soll die Toten ruhen lassen"196 ). O príncipe, por sua vez, argumenta que se a tumba é de fato uma "edificação necessária", como sustentado pelo próprio camareiro, a vigilância realizada por apenas

\footnotetext{
${ }^{195}$ Cf. G. Hirschfeld et al. (orgs.), Enzyklopädie Erster Weltkrieg, p. 512. Com a morte de Francisco José em 21 de novembro de 1916 e a posse do novo imperador, Carlos I, que tomaria para si também o posto de comandante supremo do exército, o Arquiduque Friedrich desapareceria quase completamente da vida política e militar da Áustria-Hungria.

${ }^{196}$ F. Kafka, "Oktavheft A" [Der Gruftwächter], em KKA N1, p. 268; cf. também ["Gruftwächter"-ReinschriftKonvolut], em KKA N1, p. 290.
} 
um guarda, que mora em uma pequena casa junto ao portão do parque, seria então insuficiente (seria portanto preciso um segundo guarda no interior da própria tumba):

FÜRST: Der Wächter oben im Park genügt nicht, es muß vielmehr auch ein Wächter unten in der Gruft wachen. Es wird vielleicht kein angenehmes Amt sein. Aber erfahrungsgemäß finden sich für jeden Posten bereitwillige und geeignete Leute.

KAMMERHERR: Natürlich wird alles, was Hoheit anordnen, ausgeführt werden, auch wenn die Notwendigkeit der Anordnung nicht begriffen wird.

FÜRST: Notwendigkeit! Ist denn die Wache am Parktor notwendig? Der Friedrichspark ist ein Teil des Schloßparkes, ist von ihm ganz umfaßt, der Schloßpark selbst ist reichlich, sogar militärisch bewacht. Wozu also die besondere Bewachung des Friedrichsparks? Ist sie nicht eine bloße Formalität? Ein freundliches Sterbelager für den armseligen Greis, der dort die Wache besorgt? ${ }^{197}$

PRÍNCIPE: Apenas o guarda em cima no parque não basta, é preciso também um guarda embaixo, no interior da tumba. Não será talvez um trabalho agradável. Mas, como a experiência ensina, para todos os postos encontram-se pessoas dispostas e apropriadas.

CAMAREIRO: Por certo, tudo o que a Vossa Alteza determinar será executado, ainda que a necessidade da ordem não seja compreendida.

PRÍNCIPE: Necessidade! É mesmo necessária a guarda junto ao portão do parque? O Parque Friedrich é uma parte do Parque do Palácio e é por ele completamente circundado; o próprio Parque do Palácio é fortemente vigiado, até mesmo militarmente. Para que então a vigilância especial do Parque Friedrich? Ela não é pois uma mera formalidade? Um cordial leito de morte para o velho miserável que lá se encarrega da guarda?

Diante deste impasse, o príncipe então ordena que o atual guarda - descrito pelo camareiro como "um velho transtornado, já fora de si" ("ein verwirrter Greis, schon außer Rand und Band" ${ }^{198}$ ) - seja chamado para uma audiência no palácio. O guarda entra em cena, porém, completamente esgotado: mal conseguindo parar em pé, ele é imediatamente posto em uma cama. Tão logo se recupera, e não antes da saída de cena do camareiro diante de quem se mostra amedrontado ${ }^{199}$, o guarda passa então a narrar o seu "trabalho pesado" ("schwerer Dienst"), qual seja, o de combater todas noites os "senhores da tumba" (ou seja, os ancestrais do príncipe Leo) encabeçados pelo antigo Duque Friedrich (Herzog ${ }^{200}$ Friedrich) de modo a impedir que eles escapem do parque.

\footnotetext{
${ }^{197}$ F. Kafka, "Oktavheft A" [Der Gruftwächter], em KKA N1, p. 292-293; cf. também ["Gruftwächter”-ReinschriftKonvolut], em KKA N1, p. 270/276.

${ }^{198}$ F. Kafka, "Oktavheft A" [Der Gruftwächter], em KKA N1, p. 277; cf. também ["Gruftwächter"-ReinschriftKonvolut], em KKA N1, p. 293.

${ }^{199}$ Solicitado pelo próprio príncipe a abandonar o gabinete, o camareiro ainda assim reluta: "Sehen Sie doch Hoheit, er hat Schaum vor dem Mund, er ist schwer krank."/“Veja, Alteza, ele tem espuma na boca, está gravemente doente". (F. Kafka, "Oktavheft A" [Der Gruftwächter], em KKA N1, p. 279; cf. também ["Gruftwächter"-Reinschrift-Konvolut], em KKA N1, p. 297.)

${ }^{200}$ E não se esqueça o significado original do termo "Herzog", a saber, "Herzog: führer eines heeres [líder, comandante de um exército], dux. ahd. herizoho, herizogo; mhd. herzoge [...]." (Cf. J. Grimm e W. Grimm,
} 
Como ponto fulcral dessa paráfrase anterior, cabe notar que neste principado são os mortos que não parecem interessados em deixar os vivos descansarem (variando o comentário do guarda Marcelo diante da aparição do rei defunto em Hamlet, talvez possamos já anotar: alguma coisa mostra-se podre neste principado). Como já assinalado no capítulo anterior, lembre-se que este fragmento de drama assume na produção kafkiana uma posição estratégica: trata-se do primeiro texto de Kafka a operar a suspensão da morte em sua produção. A produção que se segue passa então a ser inundada por mortos-vivos. Confira, aliás, outro assombroso fragmento kafkiano datado de 20.10.1917 (portanto, do segundo momento deste ciclo produtivo) no qual o próprio rio dos mortos, enojado, altera o curso de suas águas, passando a despejar os "mortos" de volta ao mundo dos "vivos":

\begin{abstract}
Manche Schatten der Abgeschiedenen beschäftigen sich nur damit, die Fluten des Totenflusses zu belecken, weil er von uns herkommt und noch den salzigen Geschmack unserer Meere hat. Vor Ekel sträubt sich dann der Fluß, nimmt eine rückläufige Strömung und schwemmt die Toten ins Leben zurück. Sie aber sind glücklich, singen Danklieder und streicheln den Empörten. ${ }^{201}$
\end{abstract}

Algumas sombras dos defuntos ocupam-se apenas em lamber as águas do rio da morte, porque ele vem de nós e tem ainda o gosto salgado de nosso mar. De nojo, o rio então arrepia-se, toma o curso retrógrado e despeja os mortos de volta à vida. Eles, porém, estão felizes, entoam canções de agradecimento e afagam os revoltados.

Assinale-se também o dado sintomático de que o relato do guarda da tumba sobre os seus combates noturnos ("Ringkämpfe jede Nacht") constitui nada menos que o centro nervoso do drama de Kafka. As implicações deste dado, portanto, não são pequenas, afinal dizer que o drama kafkiano tem como centro uma narrativa - ou seja, a suspensão da situação dialógica pela invasão da épica - significa ao mesmo tempo dizer que este drama tem em seu centro algo que leva à sua própria decomposição, em outras palavras ainda, algo portanto que opera a corrosão da estrutura do "drama rigoroso"202. Dito isso, não custa então transcrever aqui um fragmento mais extenso do relato do guarda da tumba:

Deutsches Wörterbuch, vol. 10, p. 1255-1256). Lembre-se também que em latim dux, ducis significava originalmente "o que vai à frente, pastor" e a partir da época imperial adquiriu a carga militar de "condutor, dirigente, guia" ("duque": historicamente, "comandante militar das províncias romanas no fim do império").

${ }^{201}$ F. Kafka, "Oktavheft G", em KKA N2, p. 33-34.

${ }^{202}$ Cf. por exemplo A. Rosenfeld, O teatro épico, p. 88: "A memória encerra o indivíduo na sua própria subjetividade, isola-o e suspende a situação dialógica, básica para o drama rigoroso. Ademais, o sujeito atual tende a objetivar o sujeito passado, estabelecendo-se, deste modo, a típica oposição sujeito-objeto da Épica." 
WÄCHTER: Bis Mitternacht ist Ruhe. Ich liege - verzeih mir - im Bett und rauche die Pfeife. Im Bett nebenan schläft mein Tochterkind. Um Mitternacht klopft es das erste Mal ans Fenster. Ich sehe nach der Uhr. Immer pünktlich. Noch zweimal klopft es, es mischt sich mit den Uhrenschlägen vom Turm und ist nicht schwächer. Das sind nicht menschliche Fingerknöchel. Aber ich kenne das alles und rühre mich nicht. Dann räuspert es sich draußen, es wundert sich, daß ich trotz solchen Klopfens das Fenster nicht öffne. [...]

WÄCHTER: Er zeigt sich gleich. Mit einem Schlage öffnen sich Fenster und Fensterladen. Knapp habe ich noch Zeit meinem Tochterkind die Decke über das Gesicht zu werfen. Sturm bläst herein, verlöscht das Licht im Nu. Herzog Friedrich! Sein Gesicht mit Bart und Haar erfüllt mein armes Fenster ganz und gar. Wie hat er sich entwickelt in den Jahrhunderten. ${ }^{203}[\ldots]$

WÄCHTER: "Alter Hund", beginnt er beim Fenster, "die Herren klopfen und Du bleibst in Deinem Schmutzbett." Gegen Betten haben sie nämlich immer Zorn. Und nun sprechen wir jede Nacht fast dasselbe. Er draußen, ich ihm gegenüber mit dem Rücken an der Tür. Ich sage: "Ich habe nur Tagdienst." Der Herzog wendet sich und ruft in den Park: "Er hat nur Tagdienst." Daraufhin gibt es ein allgemeines Lachen des versammelten Adels. Dann sagt der Herzog wieder zu mir: "Es ist doch Tag." Ich darauf kurz: "Sie irren." Der Herzog: "Tag oder Nacht, öffne das Tor." Ich: "Das ist gegen meine Dienstordnung." Und ich zeige mit dem Pfeifenstock auf ein Blatt an der Wand. Der Herzog: "Du bist doch unser Wächter." Ich: "Euer Wächter, aber vom regierenden Fürsten angestellt." Er: "Unser Wächter, das ist die Hauptsache. Also öffne undzwar sofort." Ich: "Nein." Er: "Narr, Du verlierst Deinen Posten, Herzog Leo hat uns für heute eingeladen."204

WÄCHTER: Wenn ich Deinen Namen höre, verliere ich meine Festigkeit. Deshalb habe ich mich gleich aus Vorsicht an die Tür gelehnt. Draußen singen alle Deinen Namen. "Wo ist die Einladung?" frage ich schwach. "Bettvieh", schreit er und erweckt mich ohne es zu wollen, "Du zweifelst an meinem herzoglichen Wort?" Ich sage: "Ich habe keine Weisung und deshalb öffne ich nicht, öffne ich nicht, öffne ich nicht." "Er öffnet nicht”, ruft der Herzog draußen, "also vorwärts, alle, die ganze Dynastie, gegen das Tor, wir öffnen selbst." Und im Augenblick ist es vor meinem Fenster leer. ${ }^{205}$

GUARDA: Até à meia-noite está calmo. Eu estou - perdoe-me - deitado na cama e fumo meu cachimbo. Na cama ao lado dorme minha neta. À meia-noite bate-se, uma primeira vez, à janela. Eu olho para o relógio. Sempre pontual. Bate-se ainda duas vezes, batidas estas que se misturam com as do relógio da torre e não são menos fracas. Não são de mãos humanas. Mas eu conheço tudo isto e não me mexo. Então se pigarreia lá fora, fica-se surpreso que eu apesar das batidas não abra a janela. [...]

GUARDA: Ele logo se mostra. Subitamente, janela e persiana abrem-se. Por pouco tenho ainda tempo de atirar a coberta sobre o rosto de minha neta. Uma tempestade sopra para dentro, apagando de chofre a luz. Duque Friedrich! Seu rosto com barba e cabelo preenche por inteiro minha pobre janela. Como ele se desenvolveu ao longo dos séculos! [...]

GUARDA: "Velho cão!", ele então começa junto à janela, "os senhores batem e você continua em sua cama imunda." Eles têm sempre raiva de camas. E então nós conversamos toda noite

\footnotetext{
${ }^{203}$ F. Kafka, "'Gruftwächter'-Reinschrift-Konvolut”, em KKA N1, p. 301 ou "Typoskript 'Kleines Arbeitszimmer"' [em "Oxforder Oktavheft 1"], em HKKA O1/2, p. 159.

${ }^{204}$ F. Kafka, "Oktavheft A" [Der Gruftwächter], em KKA N1, p. 284-285.

${ }^{205}$ F. Kafka, "Oktavheft A" [Der Gruftwächter], em KKA N1, p. 285.
} 
quase o mesmo. Ele do lado de fora, eu em frente a ele encostado na porta. Eu digo: "Meu serviço é apenas diurno." O Duque se vira e grita para o parque: "O serviço dele é apenas diurno!" Nisso há uma risada generalizada da nobreza ali reunida. Então o Duque me diz de novo: "Mas ainda é dia." Eu respondo seco: "O senhor se engana." O Duque: "Dia ou noite, abra o portão." Eu: "Isto é contra o regulamento do meu serviço." E eu aponto com o cachimbo uma folha na parede. O Duque: "Mas você é nosso guarda." Eu: "Guarda dos senhores, mas empregado pelo príncipe regente." Ele: "Nosso guarda, isto é o que importa. Portanto abra-o e agora." Eu: "Não". Ele: “Tolo, você vai perder o seu posto, o Duque Leo nos convidou hoje."

GUARDA: Quando ouço Vosso nome, perco minha firmeza. Por isso eu me apóio, por segurança, na porta. Do lado de fora todos cantam o Vosso nome. "Onde está o convite?" eu pergunto tímido. "Animal dorminhoco!", ele grita [...], "Você está duvidando de minha nobre palavra?" Eu digo: "eu não tenho autorização e por isso não abro, não abro, não abro." "Ele não abre", grita o Duque lá fora, "então adiante!, todos, toda a dinastia, contra o portão, nós mesmos o abriremos." E neste momento minha janela fica vazia.

Ao final do relato do guarda sobre os seus combates noturnos seguem-se então quatro continuações diferentes. Nas três primeiras, todas riscadas pelo escritor, no momento em que o príncipe abandona a cena para atender a um chamado da princesa, o camareiro e o intendente supremo da corte (Obersthofmeister) adentram o gabinete e iniciam então um diálogo na presença do guarda da tumba (a atitude do intendente para com o guarda é de extrema hostilidade). Precisamente neste diálogo o elemento político do drama passa a ser explicitamente exposto:

OBERSTHOFMEISTER: Der Fürst ist weg?

KAMMERHERR: threm Rat gemäß hat inn die Frau Fürstin jetzt rufen lassen.

OBERSTHOFMEISTER: Gut. (Wendet sich plötzlich, beugt sich hinter das Ruhebett) Und du, elendes Gespenst, wagst dich wahrhaftig hierher ins fürstliche Schloß. Fürchtest dich nicht vor dem gewaltigen Fußtritt, der dich aus dem Tor hinausbefördem wird.

WÄCHTER: ICh bin, ich bin -

OBERSTHOFMEISTER: Still, zunächst einmal still, ganz still - und hierher in den Winkel gesetzt! (Zum Kammerherrn) tch danke Ihnen für die Benachrichtigung von der Anwesenheit dieses Dings-[Wächter] dort.

KAMMERHERR: Sio lioßon mich fragon.

OBERSTHOFMEISTER: Immerhin. Und nun ein vertrauliches Wort. Absichtlich vor dem Ding [Wächter] dort. Sie, Herr Graf, kokettieren mit der Gegenpartei.

KAMMERHERR: Ist das eine Beschuldigung?

OBERSTHOFMEISTER: Vorläufig oine Befürchtung.

KAMMERHERR: Dann kann ich antworten. Ich kokettiere nicht mit der Gegenpartei, denn ich erkenno sio nicht. Ith fühlo die Strömungon, abor ich tauche mich nicht oin. Ish kommo noch von der offenen Politik her, die unter Herzog Friedrich galt. Damals war im Hofdienst die-einzige Politik, dem Fürsten zu dienen. [...] Sio kamen mit der Fürstin von oinem fremden Hof, sind oin halbes Jahr hier und wollen in den komplizierten Hofverhältnissen gleich den Schnitt aufGut und Böse hin führen? 
OBERSTHOFMEISTER: Wer blinzelt, sieht nur Komplikationen. Wor die Augen offen hält, sieht in der ersten Stunde wie nach hundert Jahren das owig Klare. Hier allerdings das traurig Klare, das sich aber schon in diesen Tagen einer hoffentlich guten Entscheidung nähert. ${ }^{206}$

INTENDENTE SUPREMO DA CORTE: Opríncipo saiu?

CAMAREIRO: Soguindo o sou consolho, a sonhora princesa mandou chamá-lo.

INTENDENTE SUPREMO DA CORTE: Ótimo. (Vira-se repentinamente e inclina-se atrás da cama) E você, fantasma miserávol, so atrovo mesmo a ontrar aqui no castolo do príncipo? Não teme o violento pontapé que o botará para fora do portão?

GUARDA: Eu estou, ouestou -

INTENDENTE SUPREMO DA CORTE: Quieto, antes de tudo, quieto, completamente calado o sontado ali-[guarda]-no-canto! (Para o camaroiro) Eu agradoço-ao-sonhor a comunicação da presença desta coisa ali.

GAMAREIRO: O sonhor mo perguntou a respeito.

INTENDENTE SUPREMO DA CORTE: Mesmo assim. E agora uma palavra om confiança. Intencionalmento dianto daquilo_[guarda]-lá. O sonhor condo ostá alinhado com partido opositor?

GAMAREIRO: Isto ó uma acusação?

INTENDENTE SUPREMO DA CORTE: Por enquanto, um temor.

CAMAREIRO: Então eu posso responder. Eu não me alinho com a oposição, pois eu não a [re]conheço. Eu sinto as correntezas mas não mergulho nelas. Eu venho da política aberta que vigorava ainda sob-o Duque Friodrich. Naquele tompo a única política ora sorvir ao príncipe. [...]. O senhor veio com a princesa de uma corte estrangeira, está aqui há meio ano e pretende distinguir de pronto nas complicadas relações da corto o bom do mal?

INTENDENTE SUPREMO DA CORTE: Aquele que pisca enxerga apenas complicações. Aquele que mantém os olhos abertos enxerga na primoira hora como após com anos a clareza eterna. Aqui, aliás, a triste clareza, que já se aproxima contudo por estes dias de uma decisão que, espera-se, seja boa.

Contudo, se é verdade que a partir do diálogo entre o intendente supremo da corte e o camareiro, o drama também passa a sublinhar o quadro de uma corte fragmentada e de uma "situação [política] insuportável" [cf. a fala do intendente: "[...] der gegenwärtige

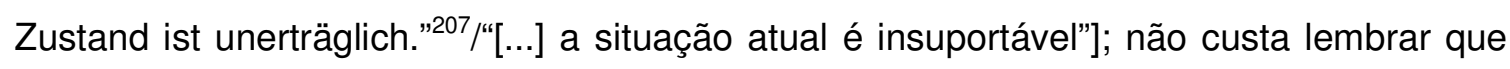
indícios deste quadro político crítico já se faziam sentir desde a conversa inicial entre príncipe e camareiro: afinal, o próprio gesto do jovem príncipe, lembre-se que ele está no poder há menos de um ano, em discutir com o camareiro suas disposições parece ser lido por este como uma espécie de vácuo político; fato, aliás, assinalado pelo próprio príncipe:

${ }^{206}$ F. Kafka, "Oktavheft A" [Der Gruftwächter], em KKA N1 App, p. 254-255.
${ }^{207}$ F. Kafka, "Oktavheft A" [Der Gruftwächter], em KKA N1 App, p. 255. 
FÜRST: Das Einzige, was Sie in der Sache beirrt, ist vielleicht nur die Sonderbarkeit, daß ich die Anordnung nicht ohne weiters getroffen, sondern vorher Ihnen angekündigt habe. ${ }^{208}$

PRÍNCIPE: A única coisa, que desconcerta o senhor nesta questão, é apenas talvez o detalhe de que eu não dei simplesmente uma ordem, mas a anunciei antes ao senhor.

Além disso, porém, as tentativas noturnos de evasão do Parque Friedrich por parte dos "senhores da tumba" também acrescentam uma nota dramática a este principado, na medida em que o coloca sob o risco de uma espécie de "invasão interna". Por fim, assinale-se ainda a existência de uma quarta e breve continuação na qual ao final do relato do guarda sobre o seus combates noturnos, o príncipe não chega a abandonar o gabinete mas o guarda da tumba logo começa a passar mal.

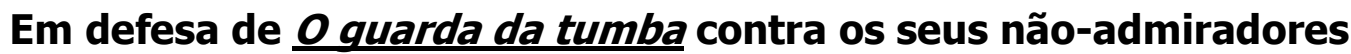

Curiosamente, a crítica kafkiana não dispensou muita atenção à única incursão dramática deste escritor. Para o importante Kafka-Handbuch organizado por Hartmut Binder e publicado em $1979^{209}$, às portas do centenário de nascimento do escritor, o crítico Jost Schillemeit, encarregado do comentário sobre o drama kafkiano, não dedicou a ele mais do que três páginas (e isso numa obra que, contando-se os dois volumes, estende-se por mais de 1.500 páginas), limitando-se na prática a constatar: "No geral, o fragmento passou quase despercebido pela crítica kafkiana." ${ }^{210} \mathrm{O}$ que espanta, contudo, é o fato de que hoje, passados mais de trinta anos desta publicação, o cenário de desprezo por este texto tenha se alterado muito pouco. Assim, se Schillemeit assinalava em seu comentário sobre $\underline{O}$ guarda da tumba, a existência até 1979 de apenas um estudo um pouco mais detido sobre o drama kafkiano: no caso, um ensaio de 20 páginas de Heinz Ide, datado de 1961 e intitulado “'Der Gruftwächter' und 'Die Truppenaushebung': zur 'religiösen' Problematik im Kafka-Werk”; um comentário mais recente sobre este texto kafkiano contido em A Franz Kafka Encyclopedia - publicada em 2005 e escrita por um grupo de estudiosos kafkianos de língua inglesa - registra, além do estudo de Ide, apenas outros dois ensaios sobre este drama: "Kafkas philosophisches Drama: 'Der

\footnotetext{
${ }^{208}$ F. Kafka, "Oktavheft A" [Der Gruftwächter], em KKA N1, p. 269; cf. também ["Gruftwächter"-ReinschriftKonvolut], em KKA N1, p. 291.

${ }^{209}$ Trata-se indiscutivelmente de um marco da crítica kafkiana. Organizado por Hartmut Binder e composto por dois volumes - Volume 1: "O homem e seu tempo"; Volume 2: "A obra e seu efeito" -, este KafkaHandbuch constitui ainda hoje uma referência imprescindível para os estudiosos de Kafka (e não apenas pelo número espantoso de críticos mobilizados em sua fatura mas principalmente pela qualidade de muitas destas contribuições).

${ }^{210}$ J. Schillemeit, "Der Gruftwächter", em Kafka-Handbuch, vol. 2, p. 499: "Im übrigen ist das Fragment in der Kafka-Forschung fast unbeachtet geblieben."
} 
Gruftwächter"' de Peter Cersowsky datado de 1990 e "'Der Gruftwächter' oder Probleme des Dramatischen im Werk Franz Kafkas" de Katharina Meinel datado de 1995. Em vista deste cenário árido, não deve causar tanto espanto o fato de que em um segundo e modesto Kafka-Handbuch, desta vez organizado por Oliver Jahraus e Bettina Jagow e publicado em 2008, O guarda da tumba sequer conste no índice dos textos kafkianos mencionados ao longo da obra!

Dito isso, ocupemo-nos brevemente destes ensaios. Partindo do depoimento deixado por Oskar Baum ${ }^{211}$, segundo o qual Kafka concebia 0 guarda da tumba como uma espécie de drama filosófico, tanto Ide quanto Cersowsky empreenderam leituras filosóficas do drama kafkiano: na esteira da filosofia de Martin Heidegger, Ide vislumbrou em $\underline{O}$ guarda da tumba uma espécie de discussão sobre a cisão entre o mundo empírico e o mundo transcendental; já para Cersowsky o drama kafkiano aludiria à dicotomia central da obra do filósofo Arthur Schopenhauer. Para interpretações como estas, o mordaz comentário de Walter Benjamin a respeito da maioria das interpretações das décadas de 1920 e 1930 que buscavam sobrepor aos textos kafkianos "esquemas filosófico-religiosos" mostra-se ainda bastante apropriado: "[...] especulações bárbaras, que de resto não são sequer compatíveis com o próprio texto literal de Kafka."212

Com relação ao artigo em A Franz Kafka Encyclopedia, se por um lado este comentário sublinha com pertinências os limites das leituras filosóficas de Ide e Cersowsky, por outro, ao enaltecer a leitura auto-referencial de Meinel - "a leitura mais persuasiva deste drama"213 (!) - acaba por destacar de tal modo a dimensão autoreferencial do texto que o resultado não é outro senão o apagamento de toda a sua carga histórica:

\footnotetext{
The fact that Kafka did most of this productive writing at night and often viewed the engagement with his own creative imagination as a struggle with ghosts reinforces the hypothesis of the autoreferential character of this drama and suggests that we read this text as a dramatization of the act of writing itself. ${ }^{214}$
}

A uma leitura como esta, caberia a seguinte pergunta: em um momento em que a velha Monarquia do Danúbio cheirava a inferno, será possível imaginar um escritor como Kafka preocupado, antes de tudo, em "dramatizar" apenas o próprio processo de escrita?

\footnotetext{
${ }^{211}$ O depoimento de Oskar Baum foi publicado originalmente em 1929 na revista Witiko: cf. O. Baum, "Erinnerungen an Franz Kafka", em H.-G. Koch (org.), "Als Kafka mir entgegenkam...”, p. 71-75.

${ }^{212}$ W. Banjamin, "Franz Kafka: a propósito do décimo aniversário de sua morte", em Magia e técnica, arte e política, p. 153.

${ }^{213}$ R. Gray et al. A Franz Kafka Encyclopedia, p. 114.

${ }^{214}$ R. Gray et al. A Franz Kafka Encyclopedia, p. 114.
} 
Diante deste panorama crítico que oscila entre o desprezo total pelo drama kafkiano e leituras que tendem ora a apagar a sua dimensão histórica, ora a sobrepor barbaramente ao texto esquemas filosóficos, é de se saudar a perspectiva recentemente inaugurada pelo crítico Peter-André Alt em sua biografia Franz Kafka: der ewige Sohn, datada de 2005. Em seu comentário sobre o drama kafkiano, Alt volta-se também, a exemplo de Ide e Cersowsky, para o depoimento de Oskar Baum, mas diferentemente dos críticos anteriores, não destaca a informação de que Kafka concebia $\underline{O}$ guarda da tumba como uma espécie de drama filosófico, mas sim um "pormenor insignificante", a saber, a informação de que Kafka durante o trabalho em seu drama estava também às voltas com o drama Hamlet de Shakespeare por conta de uma nova edição que se encontrava exposta em uma livraria de Praga. A partir deste vislumbre, Alt então assinala com pertinência:

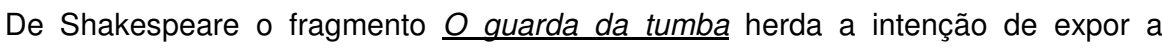
instabilidade política sob o signo da troca de poder e da descontinuidade. $O$ texto exibe na figura do príncipe um soberano que exerce a função há menos de um ano e que precisa ainda lutar pelo fortalecimento de sua autoridade; isto lembra sem dúvida a constelação histórica após a morte de Francisco José em 21 de novembro de 1916 que encerrou um reinado que havia durado 68 anos e conduziu ao trono a figura politicamente fraca de seu sobrinho-neto, Carlos I. [...]. O guarda da tumba pode assim ser lido como um drama sobre a decadência da época de Francisco José e a degradação da dignidade do império. ${ }^{215}$
}

Porém, como se verá a seguir, não foi somente o quadro político instável o que $\underline{O}$ guarda da tumba herda de Hamlet. A rigor, toda a sua produção que se desenrola entre o final de 1916 e maio de 1918 apropria-se com tamanha radicalidade do mundo de imagens contido no drama do "autor alemão"216 Shakespeare que não seria despropósito dizer que com ela Kafka leva a cabo um dos mais iluminadores e avançados "estudos" de Hamlet.

\footnotetext{
${ }^{215}$ P.-A. Alt, Franz Kafka: der ewige Sohn, p. 440. E, em nota de rodapé, Alt sublinhava o fato de que a crítica até então havia ignorado por completo a dimensão política deste fragmento: "Esta dimensão revela-se sem dúvida muito mais significativa do que a referência à filosofia de Schopenhauer (cf. P. Cersowsky); a propósito, tanto Schillemeit (em H. Binder (org.), Kafka Handbuch) quanto Robertson ignoram por completo a dimensão política deste fragmento de drama." (P.-A. Alt, Franz Kafka: der ewige Sohn, p. 714).

${ }^{216}$ Cf. G. Bornheim, Brecht: a estética do teatro, p. 104: "[...] na Alemanha existe a excelente tradução [...] de Schlegel-Tieck, que conseguiu uma proeza maior na história da literatura: a de integrar uma tradução a uma história literária outra que não a de seu berço; nesse sentido, cabe até dizer que Shakespeare é um autor alemão."
} 


\section{Shakespeare, contemporâneo de Kafka}

Não se trata de apresentar as obras literárias no contexto de seu tempo, mas de apresentar, no tempo em que elas nasceram, o tempo que as revela e conhece: o nosso.

(Walter Benjamin)

O livro 1599: um ano na vida de William Shakespeare do crítico James Shapiro apresenta com propriedade o convulsivo quadro de uma Inglaterra "fora dos eixos" em 1599: basta pensar nos vários desastres da campanha militar para tentar conter as rebeliões na Irlanda, no risco também real ao longo do ano de uma invasão por parte da Espanha; além, obviamente, das sórdidas disputas políticas já em curso pelo trono da velha Rainha Virgem e, portanto, sem herdeiros diretos. Curiosamente, neste mesmo a produção de Shakespeare sofrerá também uma decisiva inflexão (como nos lembra Shapiro, trata-se de "um ano decisivo, talvez o mais decisivo, no desenvolvimento de Shakespeare como escritor"): ao longo de 1599 Shakespeare conclui Henrique $V$ e escreve ainda Júlio César, Como gostais e o primeiro esboço de Hamlet. Não há como, portanto, ignorar as muitas afinidades entre o convulsivo quadro social e político da Dinamarca exposta em Hamlet (não se esqueça, um Estado "fora dos eixos e desenquadrado"/“disjoint and out of frame”) e a própria Inglaterra de 1599, também "fora dos eixos". ${ }^{217}$

Nada tem de espantoso portanto o fato de que Kafka tenha não apenas intuído a perturbadora atualidade de muitas das imagens exploradas pelo escritor inglês em seu

${ }^{217}$ Em Política e tragédia: Hamlet, entre Hobbes e Maquiavel, o crítico Eduardo Rinesi, por sua vez, assinala que o estado de descalabro do mundo político em Hamlet constitui "uma estilização avante la lettre daquilo que Hobbes chamaria, meio século mais tarde - pensando, por sua vez, [...] na situação da Inglaterra de seu tempo -, 'estado de natureza'”:

A abundância de metáforas bélicas no texto de Hamlet não permite que nos enganemos: a Dinamarca é um campo de batalha, Elsinor é o cenário de uma guerra "de todos contra todos". Hamlet constitui uma estetização e uma estilização antecipada daquilo que Thomas Hobbes chamaria, algumas décadas mais tarde, "estado de natureza". (E. Rinesi, Política e tragédia: Hamlet, entre Hobbes e Maquiavel, p. 91, grifo meu)

Contudo, embora Rinesi - a partir de críticos como Patrick Cruttwell: "A imaginação dos elisabetanos antecipou a realidade da guerra civil sofrida por seus netos." (P. Cruttwell apud E. Rinesi, Política e tragédia: Hamlet, entre Hobbes e Maquiavel, p. 207) - insista no caráter antecipatório do quadro exposto em Hamlet, cabe ressaltar que foi a Inglaterra do seu tempo o que Shakespeare anotou (ou, como diria Bornheim, "Shakespeare sabia o seu tempo"). Afinal, se é verdade que a história da Inglaterra conhecerá a partir de meados do século XVII uma de suas épocas mais tenebrosas, não é menos verdade que o final do reinado de Elizabeth I (que se estendeu de 1558 a 1603) estava longe de poder ser considerado uma "época dourada da Inglaterra" (como Shapiro, aliás, mostrou muito bem em seu livro): não é por acaso portanto que menos de quarenta anos após a morte de Elizabeth a Inglaterra encontrar-se-ia mergulhada em uma sangrenta Guerra Civil. 
mais conhecido drama, mas que tenha se apropriado de forma radical destas imagens com o intuito de iluminar a podridão de sua Monarquia do Danúbio em meio aos horrores da Primeira Guerra Mundial, "o maior teatro do mundo". A se levar em conta as muitas e sofisticadas apropriações do arsenal de imagens de Hamlet, pode-se ter uma idéia do quão impactante foi para Kafka a leitura deste drama no contexto da Primeira Guerra Mundial.

A propósito, quão particularmente revelador este drama de Shakespeare parece se tornar em contextos históricos convulsionados e apodrecidos dá conta a sua apropriação por parte de outros grandes escritores durante a Primeira Guerra, como Karl Kraus e Walter Benjamin. Afinal, como ignorar o fato de que Benjamin tenha esboçado $A$ origem do drama barroco alemão precisamente em 1916? Embora o objeto do livro de Benjmain seja declaradamente o drama barroco alemão, as produções de Calderón e de Shakespeare - sobretudo, Hamlet! - assumem em suas reflexões um papel estratégico. É também espantoso notar que Karl Kraus - um conterrâneo de Kafka, aliás, pois também nascido na Boêmia - encerra o prefácio de seu "drama da guerra mundial" ("Weltkriegsdrama"), intitulado Os últimos dias da humanidade e iniciado em 1915, justamente com um fragmento extraído de Hamlet. Não se esqueça ainda de Bertolt Brecht no contexto também transtornado da Segunda Guerra Mundial:

\footnotetext{
O teatro deveria estar sempre consciente das necessidades de sua época. Tomemos Hamlet, essa peça repisada, como exemplo de interpretação. Nas sombrias e sangrentas circunstâncias em que escrevo estas linhas, ante o espetáculo dos crimes perpetrados pelas classes dirigentes e a tendência geral a duvidar de uma razão que não cessa de ser mal usada, creio poder ler essa peça da seguinte maneira: é um tempo de guerra. O rei da Dinamarca, pai de Hamlet, matou o rei da Noruega durante uma guerra de rapina em que obteve a vitória. No momento em que Fortimbrás, o filho do rei da Noruega, reúne um exército para uma nova guerra, o rei da Dinamarca é morto por seu próprio irmão. Tornados reis, os irmãos dos reis desaparecidos evitam a guerra: fazem um acordo cujos termos estabelecem que a tropas norueguesas poderão atravessar a Dinamarca para ir saquear a Polônia. Ora, eis que o jovem Hamlet é chamado pelo espírito de seu pai, de humor sempre belicoso, a vingar sua morte. Depois de hesitar em responder ao crime com o crime, ele resolve exilar-se quando encontra, na costa, o jovem Fortimbrás, o qual comanda suas tropas a caminho da Polônia. Seguindo esse exemplo, ele retorna para massacrar seu tio e sua mãe, e, vítima ele próprio da carnificina, abandona a Dinamarca ao norueguês. Através desses acontecimentos, vemos Hamlet, jovem já crescido, aplicar de forma bastante lastimável a razão nova que trouxera da Universidade de Wittenberg. No mundo feudal que ele reencontra, essa razão é um
} 
obstáculo à ação. Frente às práticas insensatas, ela nada tem de prático. Hamlet cai, vítima da contradição entre esses atos insensatos e seus belos raciocínios. ${ }^{218}$

A seguir passo a assinalar, a título de ilustração, os inúmeros vestígios desta apropriação de imagens operada por Kafka em sua produção que se inicia no final de 1916 (e que infelizmente permanecerão aqui como indicação para um futuro estudo).

\section{Shakespeare, Kafka e as toupeiras}

Não há razões para se duvidar de que Kafka - no contexto da Primeira Guerra Mundial; como se sabe, uma guerra essencialmente de trincheiras ${ }^{219}$ - tenha ficado indiferente às inúmeras figuras escavando as entranhas da terra em Hamlet. A propósito, cabe ressaltar que a primeira aparição da figura da "toupeira" nos escritos de Kafka se dá em seus diários precisamente no contexto da Primeira Guerra Mundial (!). Para tanto, atente-se para a anotação datada de 04.11.1914 sobre o retorno de seu cunhado do front de batalha, o qual Kafka havia ido buscar junto com a irmã na estação de trem:

Pepa zurück. Schreiend, aufgeregt, außer Rand und Band. Geschichte vom
Maulwurf, der im Schützengraben unter ihm bohrte und den er für ein göttliches
Zeichen ansah, von dort wegzurücken. Kaum war er fort, traf ein Schuß einen
Soldaten, der ihm nachgekrochen war und sich jetzt über dem Maulwurf befand. ${ }^{220}$
Pepa voltou. Gritando, agitado, fora de si. História da toupeira que na trincheira
escavava embaixo dele e que ele tomou por um sinal divino para se afastar dali. Mal
ele havia saído, um tiro acertou um soldado que se arrastava atrás dele e que se
encontrava então sobre a toupeira.

Pouco mais de um mês após esta "história da toupeira", Kafka iniciaria a escrita de sua própria "história da toupeira", intitulada $O$ mestre-escola da aldeia - ou, caso se prefira o título inventado por Max Brod, $\underline{A}$ toupeira gigante - e que, como vimos, gira em torno da "fantástica" e "inexplicável" aparição de uma toupeira de quase dois metros de altura.

${ }^{218}$ Cf. B. Brecht apud J. Kott, Shakespeare nosso contemporâneo, p. 76-77.

${ }^{219}$ CF. W. J. Mommsen, Die Urkatastrophe Deutschlands: der Erste Weltkrieg, p. 123-124:

A típica vida do soldado foi drasticamente reduzida ao combate diário contra o frio, a lama e a umidade, contra doenças de todos os tipos e ao sofrimento passivo do bombardeio de projéteis ou da artilharia (Schrapnell- oder Artilleriebeschuss), sem que se pudesse fazer nada contra isso senão entrincheirar-se sempre mais fundo a fim de tornar a própria posição o mais seguro possível contra os bombardeios. [...]. Movia-se em um espaço estreito em um mundo quase irreal; e o fato de que no próprio e limitado campo de batalha [Gefechtsfeld] não se via de modo algum o inimigo, mas somente a algumas centenas de metros da terra de ninguém diante das próprias trincheiras, tornava as coisas ainda mais macabras. Apenas à noite o movimento entre as trincheiras e o contato com a retaguarda era possível; durante o dia tudo se limitava a cavar [Schanzearbeiten] e esperar. Também a morte nos campos nada mais tinha em comum com a tradicional morte do soldado; em vista da anônima morte em massa [anonymes Massensterben], a morte do indivíduo perdia cada vez mais seu sentido particular, e não apenas porque os corpos dos mortos em combate haviam sido, em muitos casos, mutilados até à irreconhecibilidade e, às vezes, por conta das granadas como que dissolvidos em nada.

${ }^{220}$ F. Kafka, "Zehntes Hefte", em KKA T, p. 697. 
Como bem assinala Kittler, "não é preciso nenhuma grande arte da interpretação para se reconhecer neste ser fabuloso o combatente das trincheiras da Primeira Guerra Mundial”. ${ }^{221}$

Assim sendo, é de se imaginar o assombro deste escritor ao se deparar em Hamlet com a aparição de outra "toupeira gigante" e, ainda pior, armada da cabeça aos pés (!):

MARCELLUS: Is it not like the King?

HORATIO: As thou art to thyself.

Such was the very armour he had on

When he th'ambitious Norway combated. ${ }^{222}$

HORATIO: [...] a figure like your father,

Armed at point exactly, cap-à-pie,

Appears before them, and with solemn march

Goes slow and stately by them [...].

[...] I knew your father;

These hands are not more like.

HAMLET: Arm'd, say you?

MARCELLUS / BERNARDO: Arm'd, my lord.

HAMLET: From top to toe?

MARCELLUS / BERNARDO: My lord, from head to foot. ${ }^{224}$

HAMLET: Give me one poor request.

HORATIO: What is't, my lord? we will.

HAMLET: Never make known what you have seen tonight.

HORATIO / MARCELLUS: My lord, we will not.

HAMLET: Nay, but swear't. [...] Upon my sword.

MARCELLUS: We have sworn, my lord, already.

HAMLET: Indeed, upon my sword, indeed.

GHOST: [Beneath] Swear.

HAMLET: Ah, ha, boy! say'st thou so? art thou there,

[truepenny?

Come on--you hear this fellow in the cellarage--

Consent to swear.

HORATIO: Propose the oath, my lord.

HAMLET: Never to speak of this that you have seen,

Swear by my sword.

GHOST: [Beneath] Swear.

HAMLET: Hic et ubique? then we'll shift our ground.

Come hither, gentlemen,

And lay your hands again upon my sword:
MARCELO: Não é igual ao rei?
HORÁCIO: Com tu a ti mesmo:

Aquela era sem dúvida a armadura que usou contra a

ambição da Noruega [...]. ${ }^{223}$

HORÁCIO: [...] Uma figura

Como a do rei, armado de alto a baixo,

Surge diante dos dois, e em nobre passo

Anda lento e solene [...].

[...] Eu conhecia o rei.

É realmente igual. [...].

HAMLET: Estava armado?

MARCELO E BERNARDO: Sim, senhor, armado.

HAMLET: De alto a baixo?

MARCELO E BERNARDO: Da cabeça aos pés. [...]. ${ }^{225}$

HAMLET: [...] Faço-vos um pedido.

HORÁCIO: Qual, senhor?

HAMLET: Não contais a ninguém o que aqui vistes.

HORÁCIO / MARCELO: Senhor, não contaremos.

HAMLET: Não; jurai. [...] Sobre a espada.

MARCELO: Mas nós já juramos.

HAMLET: Digo-vos: sobre a espada! Assim.

FANTASMA (gritando sob o palco): Jurai!

HAMLET: Olá, rapaz! Estás aí, amigo?

Vamos, ouviste essa voz oculta?

Consenti em jurar.

HORÁCIO: Com que palavras?

HAMLET: Nunca falar daquilo que hoje vistes,

Jurai sobre esta espada.

FANTASMA: Sim, jurai!

HAMLET: Hic et ubique? Vamos nós, portanto,

Mudar de ponto. Vinde, meus senhores,

E ponde as mãos de novo sobre a espada:

\footnotetext{
${ }^{221}$ W. Kittler, "Grabenkrieg - Nervenkrieg - Medienkrieg: Franz Kafka und der 1. Weltkrieg", em J. Hörisch e M. Wetzel (orgs.). Armaturen der Sinne, p. 290.

${ }^{222}$ W. Shakespeare, Hamlet, p. 169 [Act 1, Scene 1].

${ }^{223}$ W. Shakespeare, Hamlet, trad. de A. A. C. Mendonça, p. 31 [Ato 1, Cena 1].

${ }^{224}$ W. Shakespeare, Hamlet, p. 192-194 [Act 1, Scene 2].

${ }^{225}$ W. Shakespeare, Hamlet, trad. de A. A. C. Mendonça, p. $42-43$ [Ato 1, Cena 2], grifos meus.
} 
Never to speak of this that you have heard,

Swear by my sword.

GHOST: [Beneath] Swear.

HAMLET: Well said, old mole! canst work i' the earth so

[fast?

A worthy pioner! Once more remove, good friends.

HORATIO: O day and night, but this is wondrous strange! HAMLET: And therefore as a stranger give it welcome. There are more things in heaven and earth, Horatio, Than are dreamt of in your philosophy. ${ }^{226}$
Nunca falar daquilo que hoje ouvistes,

Jurai por minha espada.

FANTASMA: Sim, jurai!

HAMLET: Bem dito, velha toupeira! Podes escavar

[tão depressa sob a terra?

Excelente sapador! Uma vez mais saiamos daqui,

[bons amigos.

HORÁCIO: Dia e noite! Mas isto é muito estranho! HAMLET: Pois como estranho demo-Ihe acolhida! Há mais coisas, em céus e terras,

Do que sonha nossa filosofia. ${ }^{227}$

Não bastasse a esquisita aparição do rei defunto em trajes de guerra, as coisas se tornam ainda mais esquisitas no momento em que Hamlet o chama de "velha toupeira", pois com isso temos então a "fantástica" imagem de uma toupeira gigante em trajes de guerra; enfim, uma figura que em nada ficaria deslocada na galeria de personagens kafkianas. Diante disso, não nos resta outra opção senão a de concordar com o comentário perplexo de Horácio - "Dia e noite! Mas isto é muito estranho!" - e acrescentar: e como é "estranho"!

Pouco mais adiante, porém, também "assistiremos" a Hamlet escavando as entranhas da terra:

HAMLET: There's letters seal'd: and my two [schoolfellows,

Whom I will trust as I will adders fang'd,

They bear the mandate; they must sweep my way,

And marshal me to knavery. Let it work;

For 'tis the sport to have the engineer

Hoist with his own petard: and 't shall go hard

But I will delve one yard below their mines, And blow them at the moon: O, 'tis most sweet, When in one line two crafts directly meet. ${ }^{228}$
HAMLET: As cartas já estão seladas. E meus dois [companheiros de escola

Em que confio menos do que em dentes de víboras, São portadores das ordens. Devem limpar o caminho Pra eu chegar à armadilha. Vamos deixar; Pois é um prazer ver-se o engenheiro Voar pelos ares com o próprio engenho. E só muito má [sorte me impedirá

De cavar um palmo abaixo da mina deles,

Explodindo-os em pedacos até a lua. Oh, como é bonito Ver, numa mesma linha, duas maquinações se chocando. ${ }^{229}$

Por fim, lembre-se ainda da famosa cena do cemitério no último ato de Hamlet, onde além das figuras dos coveiros escavando a cova de Ofélia, assistimos também Laertes seguido por Hamlet saltarem dentro desta cova, passando então a lutar "sob a terra"|'230

\footnotetext{
${ }^{226}$ W. Shakespeare, Hamlet, p. 224-226 [Act 1, Scene 5], grifos meus.

${ }^{227}$ W. Shakespeare, Hamlet, trad. de A. A. C. Mendonça, p. 57-59 [Ato 1, Cena 5], grifos meus. A tradução do trecho em negrito, porém, é de E. Rinesi, em Política e tragédia: Hamlet, entre Hobbes e Maquiavel, p. 289290).

${ }^{228}$ W. Shakespeare, Hamlet, p.331-332 [Act 3, Scene 4], grifos meus.

${ }^{229}$ W. Shakespeare, Hamlet, trad. de M. Fernandes, p. 94 [Ato 3, Cena 4], grifos meus.

${ }^{230}$ Diante destas cenas, cf. abaixo o texto de um livro que Kafka dispunha em sua biblioteca pessoal:
} 
Repare também que, no caso de Kafka, a imagem da toupeira também volta outra vez em sua produção precisamente em $\underline{O}$ guarda da tumba (lembre-se para tanto da sintomática fala do intendente supremo da corte, referindo-se ao guarda da tumba):

Ach solche Maulwürfe bauen lange Gänge, ehe sie herkommen. ${ }^{231}$

Ah! Tais toupeiras cavam longas galerias antes de aparecerem.

\section{Shakespeare, Kafka e "um cruzamento"}

KING: [...] Two months since

Here was a gentleman of Normandy -

I have seen myself, and serv'd against, the French,

And they can well on horseback: but this gallant

Had witchcraft in't. He grew unto his seat,

And to such wondrous doing brought his horse

As had he been incorps'd and demi-natur'd

With the brave beast. So far he topp'd my thought

That I in forgery of shapes and tricks,

Come short of what he did. ${ }^{232}$
REl: [...] Há dois meses atrás

Esteve aqui um fidalgo da Normandia.

Eu mesmo vi, e militei contra os franceses;

São belos cavaleiros. Mas o nosso galante

Era mais - um feiticeiro. Colava-se na sela

E fazia o cavalo executar proezas extraordinárias,

Como se se incorporasse ao esplêndido animal,

Metade cada um da mesma natureza. Ultrapassou tudo em [minha imaginação

Pois, por mais evoluções e acrobacias que eu inventasse,

Ficava muito aquém de todas que fazia. ${ }^{233}$

É difícil imaginar que Kafka tenha ficado indiferente às sugestões sombrias desta imagem. Afinal, tratava-se de um escritor que desde os primeiros escritos havia se notabilizado pela exploração obsessiva de imagens envolvendo cavalos, cavaleiros e cavalgadas, por exemplo, "Para a meditação de grãos-cavaleiros" e "Desejo de se tornar índio" do livro Contemplação do ainda "jovem Kafka". Recorde-se também que logo após

A guerra sob a terra. Julho de 1915. Na terra as trincheiras estão inscritas; fundas, sinuosas valas. Elas correm através de campos e florestas, aldeias e cemitérios; nada levam em consideração. Diante das trincheiras estão os arames farpados, baixos e rastejantes matagais [Gestrüppe] com espinhos de ferro. Estes matagais espinhosos são criações do homem de hoje. Eles não carregam frutos; neles o homem morre como a mosca nas cerdas [Haarborsten] da planta carnívora. Entre os arames farpados, para lá e para cá, as balas das espingardas sibilam. [...]. A granada chega de longa distância e busca/tateia por tudo o que vive. Mais, ainda mais. [...]. Nós, nós que lutamos no ar, na água, sob a água, nos campos de neve, no deserto, nós lutamos hoje também sob a terra. Onde as trincheiras se aproximam tem-se a guerra de trincheira [Grabenkrieg] e também a guerra de minas [Minenkrieg]. [...]. É a guerra dos sapadores [Pioniere]!

(B. Kellermann ("Der Krieg unter der Erde", em Das große Jahr 1914-1915) apud W. Kittler, "Grabenkrieg Nervenkrieg - Medienkrieg: Franz Kafka und der 1. Weltkrieg", em J. Hörisch e M. Wetzel (orgs.). Armaturen der Sinne, p. 294.)

${ }^{231}$ F. Kafka, "Oktavheft A" [Der Gruftwächter], em KKA N1 App, p. 257.

${ }^{232}$ W. Shakespeare, Hamlet, p. 368 [Act 4, Scene 7], grifos meus.

${ }^{233}$ W. Shakespeare, Hamlet, trad. de M. Fernandes, p. 114 [Ato 4, Cena 7], grifos meus. Cf. ainda a trad. de A. W. Schlegel, p. 112: "[...] Vor zwei Monden / War hier ein Ritter aus der Normandie. / Ich kenne selbst die Franken aus dem Krieg, / Und sie sind gut zu Pferd; doch dieser Brave / Tat Zauberdinge: er wuchs am Sitze fest, / Und lenkt' sein Pferd zu solchen Wunderkünsten, / Als wär' er einverleibt und halbgeartet / Mit dem diesem wackern Tier." E também a de H. Müller, p. 99: "[...] Zwei Monate her / War hier ein Ritter aus der Normandie - / Ich selbst kenn die Franzosen aus dem Krieg / Und sie sind gut zu Pferd - doch dieser Reiter / Mit Zauberkraft wuchs er am Sattel fest und / Mit seinem Pferd vollbrachte Wunderdinge / Als ob er mit dem braven Tier ein Leib war / Und seine Hälfte." 
a ruptura estilística de 1912, este mesmo escritor logo passaria a escrever um romance sobre um "homem-cavalo" (Karl Roßmann: "Ross", como se sabe, significa "cavalo") e que este "homem-cavalo" seria recrutado para o "maior teatro do mundo" justamente em um "hipódromo"! (cf. F. Kafka, "Karl sah an einer Straßenecke [...]", em KKA V, p. 395: "Auch das wundert mich", sagte Karl, "warum geschieht denn die Aufnahme auf der Rennbahn?" "Ja", sagte Fanny, "wir machen überall die größten Vorbereitungen für den grössten Andrang. Auf der Rennplatz ist eben viel Platz."). A partir do final de 1916, como vimos, Kafka passa a explorar sistematicamente um sem-número de seres híbridos em sua produção; dentre os quais alguns resultantes precisamente da fusão entre homem e cavalo: por exemplo, o cavalo-advogado Bucéfalo em "Um novo advogado" [janeiro/fevereiro 1917] ou o servo-cavalo que sai do chiqueiro rastejando de quatro em "Um médico rural" [dezembro 1916/janeiro 1917]. Não se esqueça porém de outras narrativas desta produção que se inicia no final de 1916 que também lidam com cavalos, cavaleiros e cavalgadas: "Na galeria" [dezembro 1916/janeiro 1917], "A próxima aldeia" [dezembro 1916/janeiro 1917], "O cavaleiro do balde" [janeiro/fevereiro 1917].

\section{Um tempo "fora dos eixos"}

HAMLET: [...] So, gentlemen,

With all my love I do commend me to you:

And what so poor a man as Hamlet is

May do, to express his love and friending to you,

God willing, shall not lack. Let us go in together;

And still your fingers on your lips, I pray.

The time is out of joint: $O$ cursed spite,

That ever I was born to set it right! ${ }^{234}$
HAMLET: [...] Assim, amigos

Com todo meu afeto, me recomendo aos senhores,

E tudo que um homem tão pobre quanto Hamlet

Pude fazer pra exprimir sua amizade e gratidão,

Se Deus quiser, ele fará. Vamos entrar juntos;

E por favor, um dedo sempre sobre os lábios.

O mundo está fora dos eixos. Oh, sina maldita

Que eu tenha que ter nascido para colocá-lo em ordem. $^{235}$

Kafka, a seu turno, levará o famoso enunciado de Hamlet - "The time is out of joint" - às últimas conseqüências:

[...] o que quer dizer, podemos nos perguntar, "The time is out the joint"? Quer dizer, claro, que "o mundo está fora dos eixos". Que, caso se prefira, "o tempo" (no sentido deste tempo, do "tempo presente", o mundo presente) está fora de esquadro. Que as coisas (as coisas do mundo, as coisas presentes, o presente) estão desordenadas ou desajustadas ou fora de seus eixos. Mas a frase de Hamlet quer dizer, também, que o mundo está "de cabeça para baixo", invertido, subvertido. Ou pelo menos - se esta idéia de um desajuste total ou de uma subversão completa das coisas soar

\footnotetext{
${ }^{234}$ Cf. W. Shakespeare, Hamlet, p. 227 [Act 1, Scene 5], grifo meu.

${ }^{235}$ W. Shakespeare, Hamlet, trad. de M. Fernandes, p. 41, grifo meu. A tradução do trecho em negrito, porém, é de E. Rinesi, em Política e tragédia: Hamlet, entre Hobbes e Maquiavel, p. 41.
} 
demasiado forte -, que o mundo ou o tempo (the time, isto é: o mundo atual, o tempo presente, ou inclusive: a época) está transtornado, que é um mundo ou um tempo agitado ou comovido (e não podemos recordar senão do bom Horácio, para quem a aparição do espectro "augura ao nosso Estado alguma estranha comoção"), uma época, então, turbulenta. A conotação política da imagem é de qualquer modo evidente: "Esse mundo turbulento... completamente fora dos eixos, incapaz de ser reduzido por um longo tempo a nenhuma forma de governo pacífico" - cita Harold Jenkins, em sua notável edição de Hamlet, os Travels de Horsey. Tanto a tradução de "the time" como a época ou inclusive esta época, quanto a entonação política, ou, melhor ainda, moral, são acentuadas na tradução de André Gide ao francês da frase de Hamlet: "Cette époque est deshonorée", "esta época está desonrada" [...]. E não há dúvida de que esta sensação de uma "decadência moral", de um desajuste dos valores, de que o mundo se converteu [...] é uma constante nas considerações do príncipe sobre o estado de coisas em Elsinor e na Dinamarca [...]. E também não há dúvidas de que outras variantes, ou outros matizes, poderiam ainda [...] ser apontados [...]. Aqui só nos interessará considerar mais uma possibilidade [...] e que consiste em traduzir "the time", simplesmente, por o tempo. Em supor que é o próprio tempo - além, claro, do presente, da época, das coisas, do reino da Dinamarca - o que está em Hamlet [...] desajustado ou enlouquecido. Com efeito, não é possível, por acaso, supor que "The time is out of joint" quer dizer [...] que o próprio "the time", que a temporalidade (e não só o mundo, as coisas, o Estado, a época, esta época), está "fora dos eixos" [...]? ? $^{236}$

\section{A apropriação radical por parte do escritor de uma temporalidade "fora dos eixos" permeará não apenas $\underline{O}$ guarda da tumba, o pórtico do ciclo produtivo que se inicia no final de 1916:}

WÄCHTER: Dreißig Jahre diene ich Dir als Gruftwächter.

FÜRST: Nicht mir, meine Regierung dauert kaum ein Jahr.

WÄCHTER [in Gedanken]: Dreißig Jahre.

PAUSE

WÄCHTER: Nächte dauern dort Jahre. ${ }^{237}$

GUARDA: Há trinta anos eu sirvo a você como guarda da tumba.

PRÍNCIPE: Não a mim, meu governo mal dura um ano.

GUARDA [pensativo]: Trinta anos.

PAUSA

GUARDA: As noites lá duram anos.

WÄCHTER: Dreißig Jahren jede Nacht erwartet er [Herzog Friedrich] mich diesmal mürbe zu finden.

FÜRST: Wenn er seit dreißig Jahren kommt, dann kann es nicht Herzog Friedrich sein, der erst vor fünfzehn Jahren gestorben ist. Er ist aber der einzige dieses Namens in der Gruft. ${ }^{238}$

\footnotetext{
${ }^{236}$ E. Rinesi, Política e tragédia: Hamlet, entre Hobbes e Maquiavel, p. 129-131.

${ }^{237}$ F. Kafka, "Oktavheft A" [Der Gruftwächter;"'Gruftwächter"-Reinschrift-Konvolut], em KKA N1, p. 280-281; p. 298-299.
} 
GUARDA: Há trinta anos, todas as noites, ele [Duque Friedrich] espera me encontrar displicente.

PRÍNCIPE: Se ele aparece há trinta anos, então não pode ser o Duque Friedrich, que morreu há apenas quinze anos. Ele é no entanto o único com este nome na tumba.

mas também inúmeros outros textos deste ciclo produtivo que se seguirão a este fragmento de drama. Cf., por exemplo, em nosso primeiro capítulo a respeito das deformações temporais que passam a assolar a produção kafkiana a partir deste momento.

\section{Uma atmosfera "fora dos eixos"}

FRANCISCO: For this relief much thanks. 'Tis bitter cold,

And I am sick at heart. ${ }^{239}$

FRANCISCO: Muito obrigado pela rendição. Faz um frio

E a angústia me oprime o coração. ${ }^{240}$

HAMLET: The air bites shrewdly, it is very cold.

HAMLET: $\underline{O}$ ar está cortante, faz muito frio.

HORATIO: It is a nipping and an eager air. ${ }^{241}$ HORÁCIO: É um ar gelado e penetrante. ${ }^{242}$

Função de aludir à situação social e política do Estado: em Kafka, ao outono

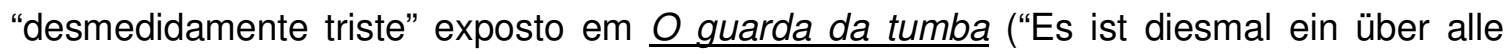
Massen trauriger Herbst”/“Trata-se desta vez de um outono triste para além de qualquer medida") segue-se em sua produção um inverno quase sem fim (cf. "Um médico rural" [dezembro 1916/janeiro 1917], "O cavaleiro do balde" [janeiro/fevereiro 1917], Em nossa casa, esta monstruosa casa de subúrbio [...]" [janeiro/fevereiro 1917], "Quando eu cheguei em casa à noite [...]" [Março 1917]) $)^{243}$.

\section{Shakespeare, Kafka e a "guerra total"}

Como se sabe, os "escritos de repartição" de Kafka dão um testemunho incontestável do quão consciente estava o escritor das implicações de uma guerra que suprimia de um modo até então desconhecido a diferença entre front e lar. Daí inclusive o

\footnotetext{
${ }^{238}$ F. Kafka, "Oktavheft A" [Der Gruftwächter; "Gruftwächter"-Reinschrift-Konvolut], em KKA N1, p. 284 ; p. 303.

${ }^{239}$ Cf. W. Shakespeare, Hamlet, p. 165 [Act 1, Scene 1].

${ }^{240}$ Trad. de E. Rinesi, em Política e tragédia: Hamlet, entre Hobbes e Maquiavel, p. 289.

${ }^{241}$ Cf. W. Shakespeare, Hamlet, p. 207 [Act 1, Scene 4].

242 Trad. de E. Rinesi, em Política e tragédia: Hamlet, entre Hobbes e Maquiavel, p. 297.

243 "Um médico rural" [dezembro 1916/janeiro 1917]: "eisiger Winter" (L, p. 7); "Was ich tue hier in diesem endlosen Winter" ( $L$, p. 20); "dem Froste dieses unglückseligsten Zeitalters ausgesetzt" ( $L$, p. 32-33). "O cavaleiro do balde" [janeiro/fevereiro 1917]: "Ungeheuer ist die Kälte [...]" (KKA N1, p. 316); "winterliche Erde" (KKA N1 App, p. 275). "Em nossa casa, esta monstruosa casa de subúrbio [...]" [fevereiro 1917]: "am nebliger eisigen Wintermorgen" (KKA N1, p. 329). "Quando eu cheguei em casa à noite [...]": "die Winterkälte" (KKA N1, p. 367).
} 
conceito de "guerra total"; empregado pela primeira vez, sublinhe-se, em alusão à Primeira Guerra Mundial. ${ }^{244} \mathrm{Em}$ meio a este estado de coisas, o "Instituto de Seguros contra Acidentes dos Trabalhadores" oferecia ao funcionário Franz Kafka uma posição estratégica para se acompanhar o palco de devastações desta guerra, que há muito havia deixado de se limitar aos campos de batalha; ou seja, enquanto muitos tombavam nos "longínquos" fronts de batalha, não poucos sucumbiam também no "front doméstico" ("Heimatfront"):

Für die Unfallverhütung, insbesondere innerhalb des Anstaltsterritoriums, bedeutet der Krieg nicht nur eine Unterbrechung ihrer vielversprechenden Entwicklung, sonder sogar eine teilweise Zerstörung des schon Erreichten. [...]. Dort aber, wo der Betrieb infolge von Heeresaufträgen oder aus sonstigen Gründen alle seine Kräfte anspannen muß, besteht wiederum die praktische Unmöglichkeit, der Unfallverhütung genügende Aufmerksamkeit zuzuwenden. [...]. Während [...] neue Unfallverhütungseinrichtungen kaum beschafft werden, ist das tatsächliche Bedürfnis nach innen ungemein gestiegen. In jenen zahlreichen Betrieben, welche schon seit langer Zeit forciert arbeiten, ist die Unfallsgefahr, also die Notwendigkeit von Gegenmaßregeln, dadurch sehr erhöht, daß ungelernte Kräfte, vor allem auch weibliche und jugendliche Arbeiter in großer Zahl eingestellt werden mußten, daß Nachtschichten und Überstunden eingeführt wurden, daß selbst das Aufsichtspersonal nicht immer ein genügendes ist und daß sogar dieses unqualifizierte Arbeitermaterial einer starken Fluktuation unterworfen ist. Es kann auch nicht vermieden werden, daß ungelernte weibliche und jugendliche Arbeiter an verhältnismäßig gefährlichen Maschinen beschäftigt werden, an Bohrmaschinen, Drehmaschinen, Pressen und sogar an Fräsmaschinen. [...]. ${ }^{245}$

${ }^{244}$ O conceito de "guerra total" foi empregado pela primeira vez em 1935 pelo general alemão Erich Luddendorff em alusão à Primeira Guerra Mundial e deixa-se definir em grandes linhas como o emprego no contexto da guerra de todos os recursos materiais à disposição e, por extensão, de toda a população (já que esta, em um tal contexto, também passa a ser concebida como "material"). Um dos termos correntes à época da Primeira Guerra, aliás, era precisamente o de "Menschenmaterial" ("material-homem") que, não por acaso, será empregado literalmente por Kafka em Durante a construção da Muralha da China. Cf. também Bernd Kleinhans, "Totaler Krieg", em http://www.zukunft-braucht-erinnerung.de/zweiter-weltkrieg/wirtschaft-undgesellschaft-im-krieg/130.html:

Der "totale Krieg" war keine Erfindung des Dritten Reiches. In der militärischen Wirklichkeit zeigten die Kriege der Neuzeit generell eine Tendenz zur "Totalisierung": War in den vormodernen Kriegen die Zivilbevölkerung allenfalls durch höhere Abgaben und punktuelle Plünderungen betroffen, wurden Kriege seit der französischen Revolution schon verstärkt als Vernichtungskriege geführt, die auch die Zivilbevölkerung zum Opfer machte. Vor allem der 1. Weltkrieg brachte eine bis dahin nicht gekannte Verschränkung zwischen Heimat und Front. Erst durch die Ausrichtung der industriellen Produktion auf Kriegszwecke konnten die für einen modernen Krieg typischen aufwendigen Waffen bereit gestellt werden. Erich Ludendorff, General im 1. Weltkrieg und späterer Verbündeter Hitlers, zog daraus die Konsequenzen und formulierte eine Doktrin des künftigen totalen Krieges. "Nicht nur die Heere, auch die Völker sind der unmittelbaren Kriegshandlung, wenn auch in ihren einzelnen Teilen abgestuft, unterworfen", schrieb er 1935 in einer Abhandlung, die in Nazi-Deutschland mehrfach neu aufgelegt wurde. Darin betonte Ludendorff auch die Bedeutung des Kriegswillens eines Volkes, das geschlossen hinter seiner Führung stehen müsse. Zu diesem Zweck verlangte er eine intensive Propaganda. Ob Goebbels und Hitler diese Schrift kannten, lässt sich nicht nachweisen, in ihren Grundgedanken stimmten sie jedenfalls mit Ludendorff überein.

${ }^{245}$ F. Kafka, "Unfallverhütung", em KKA AS, p. 479-481 (Para este "Relatório do ano de 1915", publicado porém apenas no final de 1916 em razão da guerra, Kafka escreveu, além desta seção sobre prevenção de acidentes, também outros dois artigos: "Kriegslage und Gefahrenklassen-Einreihung" e "Versicherung der 
Para a prevenção de acidentes, particularmente dentro do território abrangido pelo Instituto [de Seguros contra acidentes dos trabalhadores, acréscimo meu] a guerra significa não apenas uma interrupção do seu desenvolvimento promissor, mas até mesmo uma destruição parcial do que já havia sido alcançado. Lá porém onde a fábrica, devido às demandas do exército ou por outros motivos, precisa potencializar todos os seus esforços, subsiste em contrapartida a impossibilidade prática de se dispensar adequada atenção à prevenção de acidentes. Enquanto novos dispositivos para a prevenção de acidentes mal foram implantados, a sua necessidade efetiva aumentou de modo extraordinário. Naquelas numerosas fábricas que já há muito tempo trabalham de forma redobrada, o risco de acidentes - e portanto a necessidade de medidas contrárias - aumentou muito pelo fato de que forças não-qualificadas - sobretudo mulheres e jovens - tiveram de ser contratadas em grande número, turnos noturnos e horas extras foram implantados, o número de inspetores não é sempre suficiente e até mesmo o número de trabalhadores está sujeito a uma forte flutuação. Também não pode ser evitado que estas mulheres e jovens não-qualificados passem a operar máquinas relativamente perigosas: furadeiras, tornos mecânicos, prensas e até mesmo fresadoras.

Levando-se em conta um texto como este, escrito em 1916, é possível imaginar que Kafka tenha ficado indiferente ao contexto de um Estado também convulsionado pela guerra em Hamlet?:

MARCELLUS: Why this same strict and most

So nightly toils the subject of the land, observant watch

And why such daily cast of brazen cannon,

And foreign mart for implements of war,

Why such impress of shipwrights, whose sore task

Does not divide the Sunday from the week.

What might be toward, that this sweaty haste

Doth make the night joint-labourer with the day,

Who is't that can inform me? ${ }^{246}$
MARCELO: $\underline{\text { Por que os súditos deste país se esgotam todas }}$

Em vigílias rigidamente atentas, como esta?

Por que, durante o dia, se fundem tantos canhões de bronze?

Por que se compra tanto armamento no estrangeiro?

Por que tanto trabalho forçado de obreiros navais,

Cuja pesada tarefa não distingue o domingo dos dias de [semana?

O que é que nos aguarda, o que é que quer dizer tanto suor Transformando a noite em companheira de trabalho do dia? $\underline{\text { Quem pode me informar? }}{ }^{247}$

De forma análoga, é também muito difícil imaginar que, ao voltar a se ocupar de Hamlet em novembro de 1916, no exato momento em que os aliados suspendiam a sua ofensiva em Somme - ao final da qual mais de um milhão de soldados (entre aliados e alemães)

Barackenbauausführungen”). Cf. também neste contexto o pequeno fragmento (datado do início de fevereiro de 1917):

Manchmal glaube ich alle meine vergangenen und künftigen Sünden durch die Schmerzen meiner Knochen abzubüßen, wenn ich abend oder gar morgens nach einer Nachtschicht aus der Maschinenfabrik nachhause komme. Ich bin nicht kräftig genug zu dieser Arbeit, das weiß ich schon seit langem und doch ändere ich nichts. (F. Kafka, "Oktavheft B", em KKA N1, p. 331)

Às vezes, quando eu chego da fábrica de máquinas em casa à noite ou mesmo pela manhã após um turno noturno, eu acredito expiar, através das dores de meus ossos, todos os meus pecados passados e futuros. Eu não sou forte 0 suficiente para este trabalho, isto eu sei já há muito tempo e mesmo assim eu não mudo nada.

${ }^{246}$ W. Shakespeare, Hamlet, p. 170-172 [Act 1, Scene 1], grifos meus.

${ }^{247}$ W. Shakespeare, Hamlet, trad. de M. Fernandes, p. 15-16 [Ato 1, Cena 1], grifos meus. 
haviam morrido e cujo resultado fora um avanço territorial inferior a $10 \mathrm{~km}(!)^{248}$-, Kafka tenha ficado indiferente à perturbadora atualidade que o texto shakespeariano então assumia diante do "espetáculo" sangrento da Primeira Guerra Mundial:

HAMLET: Good sir, whose powers are these?

CAPTAIN: They are of Norway, sir.

HAMLET: How purposed, sir, I pray you?

CAPTAIN: Against some part of Poland.

HAMLET: Who commands them, sir?

CAPTAIN: The nephews to old Norway, Fortinbras.

HAMLET: Goes it against the main of Poland, sir,

Or for some frontier?

CAPTAIN: Truly to speak, and with no addition,

We go to gain a little patch of ground

That hath in it no profit but the name.

To pay five ducats, five, I would not farm it;

Nor will it yield to Norway or the Pole

A ranker rate, should it be sold in fee.

HAMLET: Why, then the Polack never will defend it.

CAPTAIN: Yes, it is already garrison'd.

HAMLET: Two thousand souls and twenty thousand

[ducats

Will not debate the question of this straw:

This is the imposthume of much wealth and peace,

That inward breaks, and shows no cause without

Why the man dies. ${ }^{249}$

[...]

HAMLET: [...] Examples gross as earth exhort me:

Witness this army of such mass and charge

Led by a delicate and tender prince,

Whose spirit with divine ambition puff'd

Makes mouths at the invisible event,

Exposing what is mortal and unsure

To all that fortune, death and danger dare,

Even for an egg-shell. [...]

And let all sleep? while, to my shame, I see

The imminent death of twenty thousand men,

$[\ldots]$
HAMLET: Meu senhor, de quem são estes exércitos?

CAPITÃO: Do rei da Noruega, meu senhor.

HAMLET: Para onde se dirigem, se permite?

CAPITÃO: Contra uma parte da Polônia.

HAMLET: Quem os comanda?

CAPITÃO: O sobrinho do rei; é Fortimbrás.

HAMLET: Vão contra toda a terra da Polônia

Ou para uma fronteira?

CAPITÃO: $\underline{\text { Para falar a verdade, }}$ sem rodeios,

Vamos tomar uma pequena terra

Que nada vale além do simples nome.

Por cinco moedas, cinco, eu não quisera cultivá-la;

E o reino da Polônia ou a Noruega não teriam mais

Se a vendessem em livre operação.

HAMLET: Então a Polônia não a defenderá.

CAPITÃO: Sim, ela já se acha guarnecida.

HAMLET: Duas mil almas, vinte mil ducados

Não são o preço dessa ninharia!

Este é o abscesso da paz e da opulência,

Que arrebenta por dentro e não exibe

Qual a causa da morte. ${ }^{250}$

HAMLET: [...] Exemplos grandes quanto a terra me incitam; Testemunha é este exército, tão numeroso e tão custoso, Guiado por um príncipe sereno e dedicado,

Cujo espírito, inflado por divina ambição,

É indiferente ao acaso invisível,

E expõe o que é mortal e precário

A tudo que a fortuna, a morte e o perigo engendram,

Só por uma casca de ovo. [...]

Deixo tudo dormir? E, pra minha vergonha,

Vejo a morte iminente de vinte mil homens

${ }^{248}$ Cf. W. J. Mommsen, Die Urkatastrophe Deutschlands: der Erste Weltkrieg, p. 68: "Quando os aliados suspenderam sua ofensiva em novembro de 1916, com um ganho territorial em média inferior a 10 quilômetros, os aliados haviam perdido 620.000 e os alemães 465.000 homens; um maquinário de guerra letal e de dimensões até então desconhecidas havia temporariamente se acalmado." A propósito, outro não foi o quadro final da ofensiva alemã em Verdun que, tendo se iniciado em fevereiro do mesmo ano, seria contudo interrompida apenas em dezembro: "Nach Anfangserfolgen auf deutscher Seite verwandelte sich die Schlacht bei Verdun in ein erbittertes Ringen um wenige Quadratkilometer von Granaten immer wieder umgepflügten Bodens, mit immer neuen Angriffe und Gegenangriffe, welche mit einem gigantischen Materialaufwand geführt wurden und bei der auf beiden Seiten bewußt ungeheure Verlust in Kauf genommen wurden. [...]. Als die Schlacht vor Verdun nach mehr als sechsmonatigem Wüten schließlich im Herbst 1916 abgebrochen wurde, hatten die Franzosen 367.000 Mann und die Deutschen 337.000 Mann verloren.” (Op. cit., p. 68, grifo meu.)

${ }^{249}$ W. Shakespeare, Hamlet, p. 344 [Act 4, Scene 4], grifos meus.

${ }^{250}$ W. Shakespeare, Hamlet, trad. de A. A. C. Mendonça, p. 127-128 [Ato 4, Cena 4], grifos meus. 
That, for a fantasy and trick of fame,

Go to their graves like beds, fight for a plot

Whereon the numbers cannot try the cause,

Which is not tomb enough and continent

To hide the slain ${ }^{251}$
Que, por um capricho, uma ilusão de glória,

Caminham para a cova como quem vai pro leito,

Combatendo por um terreno no qual não há espaço

Para lutarem todos; nem dá tumba suficiente

Para esconder os mortos? ? $^{252}$

\section{O teatro dentro do "maior teatro do mundo"}

Diante do processo de decomposição da velha Monarquia do Danúbio em meio ao "maior teatro do mundo", por que não apelar para o seu gênero talvez mais estimado? Ou, em outras palavras, por que não se valer, em tempos de desagregação da velha Áustria, de um gênero com o qual a literatura austríaca havia praticamente se afirmado? É, no mínimo, estranho que questões como esta - e que certamente contribuiriam para destruir a "extravagância" da incursão dramática de Kafka - não tenham sido sequer formuladas pela crítica kafkiana. A propósito, esta estratégia não seria nem de longe uma exclusividade de Kafka: ou terá sido um mera coincidência que entre a escrita de "으 teatro natural de Oklahama" [outubro 1914] e O guarda da tumba [novembro/dezembro 1916], Karl Kraus (como vimos, um conterrâneo de Kafka) tenha iniciado no final de julho de 1915 o trabalho em seu "drama da guerra mundial" Os últimos dias da humanidade (Die letzten Tage der Menschheit) ${ }^{253}$ ?

Faz-se necessário pensar o recurso kafkiano ao teatro dentro do contexto de sua produção e dentro do seu contexto histórico, o que fará com que o drama de Kafka perca muito de sua estranheza. Pois trata-se de uma estratégia... e de uma estratégia também empregada, não por acaso, no próprio drama de Shakespeare. Afinal, não se deve esquecer que o jovem Hamlet, no contexto de uma Dinamarca apodrecida, também se vale do teatro com o objetivo de revelar a "verdade", qual seja, que o assassinato do antigo rei fora de fato obra de seu próprio irmão e atual rei da Dinamarca. E lembre-se que até a encenação da peça (que apenas ocorrerá na segunda cena do terceiro ato), Hamlet não estava ainda seguro da veracidade do relato do rei defunto:

HAMLET: I'll have these players

Play something like the murder of my father

Before mine uncle. l'll observe his looks;

I'll tent him to the quick. If a do blench,

I know my course. The spirit that I have seen

May be the devil, and the devil hath power
HAMLET: Sie [die Schauspieler] sollen was

Wie die Ermordung meines Vaters spielen

Vor meinem Oheim; ich will seine Blicke

Beachten, will inn bis ins Leben prüfen:

Stutzt er, so weiß ich meinen Weg. Der Geist, den ich gesehen,

Kann ein Teufel sein; der Teufel hat Gewalt,

\footnotetext{
${ }^{251}$ W. Shakespeare, Hamlet, p. 345 [Act 4, Scene 4], grifos meus.

${ }^{252}$ W. Shakespeare, Hamlet, trad. de Millôr Fernandes, p. 102 [Ato 4, Cena 4], grifos meus.

${ }^{253}$ Publicado originalmente ao longo de 4 edições especiais da revista Die Fackel entre 1918 e 1919 e posteriormente em forma de livro em 1922. É sem dúvida notável que Kraus também encerre o prefácio de seu drama com um fragmento extraído justamente de Hamlet!
} 
T'assume a pleasing shape, yea, and perhaps, Out of my weakness and my melancholy, As he is very potent with such spirits, Abuses me to damn me: I'll have grounds More relative than this. The play's the thing Wherein I'll catch the conscience of the King. ${ }^{254}$
Sich zu verkleiden in lockende Gestalt; ja und vielleicht, Bei meiner Schwachheit und Melancholie (Da er sehr mächtig ist bei solchem Geistern) Täuscht er mich zum Verderben: ich will Grund, Der sichrer ist. Das Schauspiel sei die Schlinge, $\underline{\text { In die den König sein Gewissen bringe. }} .{ }^{255}$

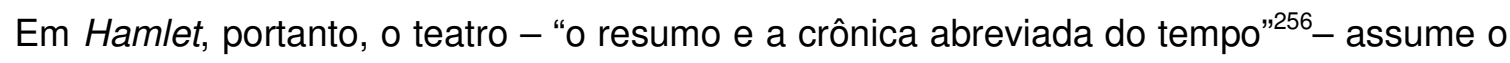
propósito declarado de produzir conhecimento. Outro não é, aliás, o propósito revelado por Horácio, o qual, diante da sangrenta "cena" final, solicita que todos os corpos sejamentão expostos "sobre um palco" (!) - "on a stage" - para que possa assim "contar ao mundo que ainda desconhece como estas coisas se passaram":

FORTINBRAS: Where is this sight?

HORATIO: What is it you would see?

If aught of woe or wonder, cease your search.

FORTINBRAS: This quarry cries on havoc. $\mathrm{O}$ [proud Death,

What feast is toward in thine eternal cell,

That thou so many princes at a shot

So bloodily hast struck?

FIRST AMBASSADOR: The sight is dismal [...]

HORATIO: [...] give order that these bodies

High on a stage be placed to the view;

And let me speak to the yet unknowing world

How these things came about: so shall you hear

Of carnal, bloody, and unnatural acts,

Of accidental judgments, casual slaughters,

Of deaths put on by cunning and forced cause,

And, in this upshot, purposes mistook

Fall'n on the inventors' reads: all this can I

Truly deliver. ${ }^{257}$
FORTINBRAS: Wo ist dies Schauspiel?

HORATIO: Was ist's, das Ihr zu sehn begehrt?

Wenn irgend Weh oder Wunder, laßt vom Suchen ab!

FORTINBRAS: Die Niederlage hier schreit Mord. - O Stolzer

[Tod,

Welch Fest geht vor in deiner ew'gen Zelle,

Daß Du auf einen Schlag so viele Fürsten

So blutig trafst?

ERSTER GESANDTER: Der Anblick ist entsetzlich [...]

HORATIO: [...] so ordnet an, daß diese Leichen

Hoch auf einer Bühne vor aller Augen werden ausgestellt,

Und laßt der Welt, die noch nicht weiß, mich sagen,

Wie alles dies geschah; so sollt ihr hören

Von Taten, fleischlich, blutig, unnatürlich,

Zufälligen Gerichten, blindem Mord;

Von Toden, durch Gewalt und List bewirkt,

Und Planen, die verfehlt, zurückgefallen

Auf der Erfinder Haupt: dies alles kann ich

Mit Wahrheit melden. ${ }^{258}$

${ }^{254}$ W. Shakespeare, Hamlet, p. 272-273 [Act 2, Scene 2], grifos meus. Não se esqueça ainda que Hamlet chamará esta peça de The Mousetrap ( $A$ ratoeira) e que ela se desenrola na capital da Monarquia do Danúbio $(!)$ :

KING: What do you call the play?

HAMLET: The Mousetrap - marry, how tropically! This play is the image of a murder done in Vienna - Gonzago is the Duke's name; his wife Baptista - you shall see anon. 'Tis a knavish piece of work, but what o' that? (W. Shakespeare, Hamlet, p. 302 [Act 3, Scene 2].)

${ }^{255}$ W. Shakespeare, Hamlet, trad. de A. W. Schlegel, p. 61 [Ato 2, Cena 2], grifos meus.

${ }^{256}$ Cf. W. Shakespeare, Hamlet, p. 268 [Act 2, Scene 2]: "the abstract and brief chronicles of the time". Trad. de A. W. Schlegel, p. 58: "der Spiegel und die abgekürzte Chronik des Zeitalters". Trad. de H. Müller, p. 52: "der Brennspiegel und die abgekürzte Chronik der Zeit".

${ }^{257}$ W. Shakespeare, Hamlet, p. 416-419 [Act 5, Scene 2], grifos meus.

${ }^{258}$ W. Shakespeare, Hamlet, trad. de A. W. Schlegel, p. 139-140 [Ato 5, Cena 2]. Não por acaso, aliás, Karl Kraus encerrará justamente com esta fala de Horácio (e na bela tradução de Schlegel) o prefácio de seu 
Exatamente esta será também a estratégia de Kafka ao se valer do teatro (da forma dramática) dentro do "maior teatro do mundo": a função de expor "sobre um palco" a decomposição da velha Monarquia do Danúbio em meio aos horrores da guerra.

"drama da guerra mundial" Os últimos dias da humanidade que, por sua vez, também tinha o propósito assumido de produzir conhecimento:

Die Aufführung des Dramas, dessen Umfang nach irdischem Zeitmaß etwa zehn Abende umfassen würde, ist einem Marstheater zugedacht. [...]. Die unwahrscheinlichsten Taten, die hier gemeldet werden, sind wirklich geschehen; ich habe gemalt, was sie nur taten. Die unwahrscheinlichsten Gespräche, die hier geführt werden, sind wörtlich gesprochen worden; die grellsten Erfindungen sind Zitate. 


\section{PARTE 2:}

\section{$O$ ponto de vista da decomposição}

$[\ldots]$ if a be not rotten before a die [...].

(William Shakespeare, Hamlet, 1599) $^{259}$

Eine stinkende Hündin, reichliche Kindergebärerin, stellenweise schon faulend, die aber in meiner Kindheit mir alles war, die in Treue unaufhölich mir folgt, die ich zu schlagen mich nicht überwinden kann und vor der ich, ihren Athem scheuend, schrittweise rückwärts weiche und die mich doch, wenn ich mich nicht anders entscheide, in den schon sichtbaren Mauerwinkel drängen wird, um dort auf mir und mit mir gänzlich zu verwesen, bis zum Ende - ehrt es mich? das Eiter- und Wurmfleisch ihrer Zunge an meiner Hand.

(Franz Kafka, “Ein Leben”, 1917)

A seguir iluminaremos a poderosa constelação de "pequenas narrativas" escritas na esteira do fragmento de drama de Kafka e que, como se verá, evidencia ainda mais o objeto das preocupações deste escritor, a saber, o avançado estado de decomposição da velha Monarquia do Danúbio em meio aos horrores da guerra.

Em um comentário recente (2010) sobre a narrativa fragmentária Durante a construção da Muralha da China [março 1917], o crítico Benno Wagner observou com propriedade:

Se, segundo um largo consenso entre historiadores, a Primeira Guerra Mundial pode ser tomada como a "catástrofe primeva" do "breve" século XX (1914-1989), o início de 1917 deveria então ser destacado como a fase decisiva em sua evolução. Entre o final de janeiro e meados de março, com o anúncio da Doutrina Wilson, com a crise dos

\footnotetext{
${ }^{259}$ W. Shakespeare, Hamlet, p. 385 [Act 5, Scene 1]. Trad. de Millôr Fernandes (W. Shakespeare, Hamlet, p. 123 [Ato 5, Cena 1]): "[...] se já não estava podre antes de morrer [...]". Trad. de A. W. Schlegel, p. 122: "[...] wenn er nicht schon vor dem Tod verfault ist [...]."

${ }^{260}$ F. Kafka, "Oktavheft G” [“Ein Leben”/“Uma vida”]; 21.10.1917], em KKA N2, p. 37: "Uma cadela fedorenta, que pariu incontáveis vezes, em algumas partes já apodrecendo, mas que na minha infância era tudo para mim, que com fidelidade me segue sem parar, a qual eu não me contenho em bater, e diante da qual eu, temendo o seu hálito, recuo passo a passo e que me empurrará, caso não tome outra decisão, para o canto do muro que já está visível; para lá apodrecer completamente sobre mim e comigo até o fim - isto me honra? - com a carne purulenta e verminosa de sua língua em minha mão."

À margem, assinale-se ainda a ocorrência também em Hamlet da imagem de um cachorro sendo consumido por vermes; com a diferença brutal, é claro, de que aqui o cachorro, ao menos, já morreu:
}

HAMLET: For if the Sun breed maggots in a dead dog, being a good kissing carrion [...].

(W. Shakespeare, Hamlet, p. 246 [Act 2, Scene 2].)
HAMLET: Denn wenn die Sonne Maden in einem toten Hunde ausbrütet: eine Gottheit, die Aas küßt [...]. (W. Shakespeare, Hamlet Trad. de A. W. Schlegel, p. 48 [Ato 2, Cena 2].) 
submarinos e com a entrada dos Estados Unidos na guerra, bem como com a Revolução Russa de Fevereiro, o final das monarquias européias, até mesmo para os observadores contemporâneos, já estava mais do que assinalado. [...]. É tudo menos acaso o fato de que Kafka, justamente no ponto de colisão de todos estes acontecimentos e tendências, empregue pela primeira vez uma matriz histórico-política em amplo sentido (Nação, Estado, Território, Povo) no lugar da matriz sócio-familiar que predominava em seus mundos ficcionais até então. ${ }^{261}$

A este pertinente comentário de Benno Wagner cabe contudo um pequeno e significativo reparo: pois se Kafka, de fato, explora nitidamente uma matriz histórico-política em Durante a construção da Muralha da China, não há dúvida entretanto de que um primeiro esboço desta matriz já se encontrava traçado precisamente em $\underline{O}$ guarda da tumba: 0 principado como unidade política e territorial, a figura do príncipe como chefe de Estado, a corte fragmentada e a igualmente explícita referência ao povo. ${ }^{262}$

Cabe enfatizar, porém, o dado sintomático de que este primeiro esboço de uma matriz histórico-política encontra-se já sob o signo da decomposição. Afinal, a "situação" deste principado é já a do descalabro político:

OBERSTHOFMEISTER: [...] der gegenwärtige Zustand ist unerträglich.

KAMMERHERR: Er mag unerträglich sein, aber er kommt aus dem Wesen der Dinge hier und wir würden inn bis zum Ende tragen.

OBERSTHOFMEISTER: Aber die Fürstin nicht, ich nicht, die zu uns halten nicht. ${ }^{263}$

INTENDENTE SUPREMO DA CORTE: [...] a situação atualé insuportável.

GAMAREIRO: Ela podo sor insuportávol, mas vom da natureza das coisas aqui- o nós a suportaríamos até o fim.

INTENDENTE SUPREMO DA CORTE: Mas a princesa, não; eu, não; aqueles que nos apóiam, กล̃o.

A este quadro político "insuportável" vem se juntar ainda a ameaça de uma "invasão interna" por parte dos "senhores da tumba": lembre-se para tanto do relato do guarda da

${ }^{261}$ B. Wagner, "Beim Bau der chinesischen Mauer", em B. Auerochs; M. Engel (orgs.). Kafka-Handbuch, p. 253-254.

${ }^{262}$ CF. F. Kafka, "Oktavheft A" [Der Gruftwächter], em KKA N1 App, p. 255:

OBERSTHOFMEISTER: Der Fürst hat eine Doppelgestalt. Die eine beschäftigt sich mit der Regierung und schwankt geistesabwesend vor dem Volk, mißachtet die eigenen Rechte. Die andere sucht zugegebenermaßen sehr präzis nach Verstärkung ihres Fundaments.

INTENDENTE SUPREMO DA CORTE: O príncipe tem uma natureza dupla. A que se ocupa do governo vacila distraído diante do povo, desprezando os próprios direitos. A outra, de modo reconhecidamente muito preciso, busca 0 fortalecimento de seu fundamento.

${ }^{263}$ F. Kafka, "Oktavheft A" [Der Gruftwächter], KKA N1 App, p. 255. 
tumba sobre os seus combates noturnos para impedir que os ancestrais do atual príncipe escapem do Parque Friedrich.

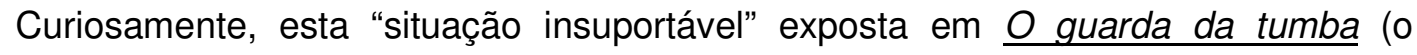
primeiro esboço kafkiano de uma matriz histórico-política) passa contudo a ressoar em uma série de narrativas escritas na esteira deste fragmento de drama; com o agravante porém de que o "ambiente social" retratado nestas narrativas revela-se cada vez mais deteriorado. No capítulo anterior havíamos assinalado como Kafka a partir de 1912 havia explorado sistematicamente narrativas em 3aㅡ pessoa (projetadas porém a partir do "herói") e que com a inflexão formal do final de 1916 as narrativas em $1^{\text {a }}$ pessoa passam a predominar em sua produção. Um olhar um pouco mais atento, contudo, é capaz de revelar um dado curioso, a saber, estes narradores em $1^{\text {a }}$ pessoa recorrem insistentemente a um "nós", assumindo assim o ponto de vista de uma coletividade: sintomaticamente, porém, trata-se também nestas narrativas do ponto de vista de uma coletividade sob o signo da desagregação, da dissolução, da decomposição.

\section{"Chacais e árabes"}

[...] es scheint ein sehr alter Streit, liegt also wohl im Blut, wird also vielleicht erst mit dem Blut enden.

(Franz Kafka, "Schakale und Araber", 1917) ${ }^{264}$

Em "Chacais e Árabes" [janeiro/fevereiro 1917] deparamo-nos com a primeira destas ocorrências: um narrador em primeira pessoa, proveniente da Europa, mas que abre o seu texto sintomaticamente a partir de um "nós" ("Wir lagerten in der Oase. Die Gefährten schliefen."/“Nós acampávamos no oásis. Os companheiros dormiam”). Este "nós", proveniente da Europa, e em excursão pelo deserto, logo toma conhecimento da penosa convivência entre duas coletividades que habitam um mesmo território: os árabes e os chacais. Curiosamente esta difícil convivência é, por sua vez, exposta a partir das falas de duas personagens - o mais velho dos chacais ("der älteste Schakal”) e o guia árabe da caravana dos europeus (“Araberführer”) - que, a seu turno, também apelam para um "nós":

\footnotetext{
${ }^{264}$ F. Kafka, "Oktavheft B" ["Schakale und Araber"], em KKA N1, p. 318. Trad. de Modesto Carone (F. Kafka, "Chacais e árabes", em $M R$, p. 31): "[...] parece ser uma disputa muita antiga; seguramente está no sangue e talvez por isso só termine com sangue."
} 
"[...] niemals in der Weltgeschichte ein Schakal einen Araber gefürchtet hat. Fürchten sollen wir [Schakale] sie [Araber]? Ist es nicht Unglück genug, daß wir unter solches Volk verstoßen sind." [...]. "Frieden müssen wir haben von den Arabern, atembare Luft, gereinigt von innen den Ausblick rund am Horizont, kein Klagegeschrei eines Hammels, den der Araber absticht, ruhig soll alles Getier krepieren, ungestört soll es von uns leergetrunken und bis auf die Knochen gereinigt werden. Reinheit, nichts als Reinheit wollen wir" - und nun weinten, schluchzten alle, besinnungslos stießen die zwei hinter mir mit ihren Köpfen in mich - "wie erträgst nur Du es in dieser Welt, Du edles Herz und süßes Eingeweide. Schmutz ist ihr Weiß, Schmutz ist ihr Schwarz, ein Grauen ist ihr Bart, speien muß man beim Anblick ihrer Augenwinkel und heben sie den Arm, tut sich in der Achselhöhle die Hölle auf. Darum o Herr, darum o teuerer Herr, mit Hilfe Deiner alles vermögenden Hände, mit Hilfe Deiner alles vermögenden Hände schneide ihnen mit dieser Scheere die Hälse durch." 265

- [...] nunca na história do mundo um chacal teve medo de um árabe. Deveríamos [nós, Chacais] ter medo deles [árabes]? Não é desgraça suficiente termos sido jogados no meio de um povo como esse? [...]. [Nós] Precisamos de paz com os árabes, de ar respirável; purificada da presença deles a vista em torno do horizonte; nenhum grito de lamúria de um carneiro que o árabe esfaqueia; todos os animais devem morrer tranqüilamente, bebidos por nós sem transtorno ao ponto de ficarem vazios e limpos até os ossos. Limpeza, nada mais que limpeza é o que nós queremos - e aí todos choraram e soluçaram. - Como suporta viver neste mundo, ó nobre coração e doces entranhas? A sujeira é o branco deles, a sujeira o seu preto; um horror a sua barba; é preciso cuspir à vista do canto dos seus olhos; e se erguem o braço, o inferno se abre na sua axila. Por isso, senhor, por isso, ó caro senhor, com a ajuda destas mãos que tudo podem, com a ajuda de suas mãos que tudo podem, cortem-lhes de lado a lado o pescoço com esta tesoura! $!^{266}$

"Eine unsinnige Hoffnung haben diese Tiere [Schakale], Narren, wahre Narren sind sie. Wir [Araber] lieben sie deshalb, es sind unsere Hunde, schöner als die Eurigen. [...]. Gesehn hast Du sie. Wunderbare Tiere, nicht wahr? Und wie sie uns hassen!"267

- [...] Esses animais têm uma esperança absurda; são loucos, verdadeiros loucos. Por isso nós os amamos; são nossos cães, mais belos que os de vocês. [...]. Você os viu. Animais maravolhosos, não é verdade? E como nos odeiam! ${ }^{268}$

${ }^{265}$ F. Kafka, "Oktavheft B" ["Schakale und Araber"], em KKA N1, p. 318-321.

${ }^{266}$ F. Kafka, "Chacais e árabes", em MR, p. 31-33.

${ }^{267}$ F. Kafka, "Oktavheft B" ["Schakale und Araber"], em KKA N1, p. 321-322.

${ }^{268}$ F. Kafka, "Chacais e árabes”, em MR, p. 34-35. 


\section{"Um novo advogado"}

Zu morden verstehn zwar manche [...].

(Franz Kafka, "Der neue Advokat", 1917) ${ }^{269}$

Em "Um novo advogado" [janeiro/fevereiro 1917] o narrador de imediato nos informa de que "nós temos um novo advogado, o Dr. Bucéfalo" (ninguém menos que o antigo cavalo de batalha de Alexandre da Macedônia) para em seguida sublinhar a situação de descalabro político de sua "coletividade" ou "sociedade", se se quiser: afinal, "hoje - isso ninguém pode negar - não existe nenhum grande Alexandre. [...]. Hoje [...] ninguém mostra a direção, muitos seguram espadas, mas só para brandi-las; e o olhar que quer segui-las se confunde."270

\section{"Em nossa casa, esta monstruosa casa de subúrbio [...]"}

In unserm Haus hat man keine Zeit und keine Lust Aufrufe zu lesen oder gar zu überdenken. Bald schwammen die kleinen Papiere in dem Schmutzstrom der vom Dachboden ausgehend, von allen Korridoren genährt, die Treppe hinabspült und dort mit dem Gegenstrom kämpft der von unten hinaufschwillt.

(Franz Kafka, "In unserm Haus, diesem ungeheuern Vostadthaus [...]", 1917) 271

Em "Em nossa casa, esta monstruosa casa de subúrbio [...]" [fevereiro 1917], voltamos a nos deparar com outro destes narradores: neste caso, um dos moradores de uma "monstruosa casa de subúrbio" ("ungeheueres Vorstadthaus") fazendo também uso de um "nós". Este narrador relata-nos o conteúdo de dois apelos divulgados no interior desta casa na qual se nota uma convivência já sentida como problemática pelos seus próprios moradores: "An alle meine Hausgenossen. [...]. Denn Einheitlichkeit muß sein, ohne Einheitlichkeit kommen wir nicht vorwärts." "A todos os meus companheiros de casa. [...]. Pois é preciso haver unidade, sem unidade nós não avançamos."

A este quadro já em si crítico e belicoso da "habitação coletiva" - ou seja, o cenário de uma convivência, no mínimo, problemática exposta pelos manifestos - vem então se somar o dado nada acidental que também nesta casa a água de seu esgoto não apenas corre a "céu aberto", mas tende a se represar, ou seja, a se acumular em seu térreo;

\footnotetext{
${ }^{269}$ F. Kafka, "Oktavheft B" ["Der neue Advokat”], em KKA N1, p. 327. Trad. de Modesto Carone (F. Kafka, "Um novo advogado", em MR, p. 11): "É verdade que muitos sabem matar [...]."

${ }^{270}$ F. Kafka, "O novo advogado", em MR, p. 11-12.

${ }^{271}$ F. Kafka, "Oktavheft B" ["In unserm Haus, diesem ungeheuern Vostadthaus [...]"], em KKA N1, p. 330: "Em nossa casa não se tem tempo nem vontade de se ler apelos ou mesmo de refletir sobre eles. Logo os pequenos papéis nadavam na corrente de água do esgoto que, partindo do sótão, é alimentada por todos os corredores, escorre pela escada e luta com a contracorrente [de água do esgoto] que jorra do andar de baixo."
} 
afinal, a corrente desta água do esgoto oriundo do sótão desce pela escada para então se encontrar - ou melhor, lutar (!) [“kämpft”] - com uma contracorrente que jorra do andar de baixo. Não resta dúvida de que algo está podre nesta casa.

À margem, vale ressaltar que à época a situação dos "moradores" de outra "monstruosa casa", a "Casa de Áustria" ("Haus Österreich"272), nos subúrbios da velha Europa, não era menos dramática. Dentro deste contexto, não custa então registrar outros manifestos ou apelos divulgados nesta outra "casa"; como, por exemplo, aquele datado de 28.07.1914 em que o imperador Francisco José ordena ao "Ministro de Minha Casa" ("Minister Meines Hauses"), o Primeiro Ministro Karl Graf Stürgkh, que declare guerra à Sérvia e em seguida solicita a ampla divulgação de seu manifesto "Aos meus povos!" ("An meine Völker!") em que comunica a todos os súditos o atual estado de guerra. Outro exemplo notável é certamente o apelo escrito pelo próprio Kafka para o Instituto de Seguros contra Acidentes dos Trabalhadores e datado de outubro de 1916, o qual notifica a criação de uma "Associação alemã para a fundação e a manutenção de um hospital psiquiátrico público na Boêmia alemã [Deutschböhmen]" e solicita o suporte financeiro da população (repare como Kafka mimetiza em sua narrativa, escrita pouco mais de três meses depois, a estrutura deste apelo e também para o sintomático emprego do "nós", marca registrada de inúmeras narrativas deste mesmo período):

Volksgenossen!

Der Weltkrieg, der alles menschliche Elend gehäuft in sich enthält, ist auch ein Krieg der Nerven, mehr Krieg der Nerven als je ein früherer Krieg. In diesem Nervenkrieg unterliegen nur allzuvielen. So wie im Frieden der letzten Jahrzehnte der intensive Maschinenbetrieb die Nerven der in inm Beschäftigten unvergleichlich mehr als jemals früher gefährdete, störte und erkranken ließ, hat auch der ungeheuerlich gesteigerte maschinelle Teil der heutigen Kriegshandlungen schwerste Gefahren und Leiden für die Nerven der Kämpfenden verursacht. [...].

Was sollen wir tun? Wir haben die Wahl: Wir können alles seinen bisherigen Weg gehen lassen. Wir können zusehen, wie die Nervenkranken aus der Front in die militärischen Spitäler strömen und wie sie dort nur zum geringsten Teil in die beschränkten besonderen Nervenabteilungen kommen, im Übrigen aber nur in die allgemeinen militärischen Unterkünfte gelangen. In den besonderen Abteilungen werden ja gewiß Besserungs- und Heilerfolge erzielt, so vorzüglich, als dies bei den unvollständigen Behelfen dort möglich ist. Aber wie wenig Glückliche erhalten diese Behandlung! Und die Überzahl der in den allgemeinen Spitälern untergebrachten Nervenkranken, was geschieht mit diesen? Innen kann heute der beste Wille und die größte medizinische Kunst nichts helfen. Für sie ist in ihrer Heimat, die sie mit ihrem Leben verteidigt und für

\footnotetext{
272 O termo alemão "Haus Österreich" deriva, a rigor, da expressão espanhola "Casa de Austria", designação empregada habitualmente desde o século XV (o primeiro registro da expressão data contudo de 1306) para se referir tanto aos domínios territoriais (“Hausmacht”) quanto à própria dinastia dos Habsburgo.
} 
die sie ihre und ihrer Angehörigen Zukunft eingesetzt haben, keine Hilfe vorhanden, denn Hilfe kann nur eine sorgfältige Behandlung in einer neuzeitlich eingerichteten Heilanstalt bringen. Da diese aber nicht vorhanden ist, ist auch das Schicksal dieser Unglücklichen besiegelt. Sie werden ungeheilt in ihre Heimat entlassen, als Vermehrung der ungeheilten Nervenkranken aus der Friedenszeit, als Opfer endloser, stetig sich verschärfender Leiden, als Qual ihrer Familien, als Verlust der deutsch-böhmischen Volkskraft, als Anwärter der Irrenhäuser. Soll das der Lohn sein, mit dem Deutschböhmen seine Söhne lohnt?

Aber es gibt noch eine andere Möglichkeit! Deutschböhmen, das heißt die Gesamtheit der deutschen Volksgenossen, kann aus eigenen Mitteln eine große Volksnervenheilanstalt errichten $[\ldots . .]^{273}$

\section{Companheiros de povo!}

A guerra mundial, que freqüentemente traz em si toda a miséria humana, é também uma guerra de nervos; e mais guerra de nervos do que qualquer outra guerra anterior. Nesta guerra de nervos muitos sucumbem. Assim como na paz da última década o intensivo emprego de máquinas colocou em perigo, transtornou e fez adoecer, incomparavelmente mais do que jamais outrora, os nervos daqueles que se ocupavam delas; também a participação que cresceu de forma espantosa das máquinas nas atuais ações militares provoca os mais graves riscos e sofrimentos para os nervos dos combatentes. [...].

O que nós devemos fazer? Nós temos a escolha: podemos deixar que tudo siga o seu atual caminho. Podemos assistir como os doentes dos nervos afluem do front para os hospitais militares e como lá somente a mais ínfima parte deles chega às limitadas unidades especializadas em nervos; a todos os demais restam porém apenas os alojamentos militares gerais. Não há dúvida de que nas unidades especializadas são obtidas melhoras e curas [...]. Mas quão poucos felizardos conseguem este tratamento! $\mathrm{E}$ quanto à maioria dos doentes dos nervos acomodados nos hospitais gerais, o que acontece com eles? [...]. Para eles não há em seu próprio lar, que defenderam com sua vida e pelo qual puseram em risco o seu futuro e o dos seus familiares, nenhuma ajuda; pois ajuda apenas um tratamento cuidadoso em um hospital modernamente equipado pode trazer. Uma vez, porém, que este não existe, também o destino destes infelizes está selado. [...]. Esta deve ser a recompensa paga pela Boêmia alemã a seus filhos? Mas há ainda uma outra possibilidade! A Boêmia alemã, ou seja, o conjunto dos companheiros de povo pode fundar com meios próprios um grande hospital psiquiátrico público [...].

Em um texto como este, é preciso, contudo, cautela para não se confundir o ponto de vista do escritor com o ponto de vista da Instituição. Afinal, este "apelo" precisava

${ }^{273}$ F. Kafka, "Deutscher Verein zur Errichtung und Erhaltung einer Krieger- und Volksnervenheilanstalt in Deutschböhmen in Prag", em KKA AS, p. 498-499. Este apelo foi assinado por mais de 100 pessoas da vida pública da Boêmia alemã, entre os quais, evidentemente, o "Dr. Franz Kafka, vice-secretário do Instituto de Seguros contra Acidentes dos Trabalhadores da Boêmia em Praga". Kafka chegou a enviar este manifesto junto com uma carta a Felice Bauer datada de 30.10.1916: "Du findest mich unter den Unterzeichnern [...]. Auch der Text (wie so vieler anderer) ist von mir."/“Você me encontra entre os signatários [...]. Também este texto (como tantos outros) foi escrito por mim." (F. Kafka, Briefe an Felice, p. 737.) 
evidentemente adequar-se ao posicionamento da instituição para o qual é escrito; neste caso, um instituto semi-estatal. Certamente não escapou a Kafka o que, porém, podia ser lido em suas entrelinhas: a saber, que a população tenha de se mobilizar para ajudar contingentes cada vez maiores de inválidos de guerra era, por si só, o retrato mais acabado do colapso deste Estado, ou seja, o testemunho cabal de que, de fato, este Estado havia levado seus "filhos" à guerra e, em seguida, os abandonado à própria sorte. Pois a pergunta que o apelo direcionava à população - "Soll das der Lohn sein, mit dem Deutschböhmen seine Söhne lohnt?"/“Esta deve ser a recompensa paga pela Boêmia alemã a seus filhos?" - continha em si mesma, latente, uma afirmação: "Esta é a recompensa paga pela Casa de Áustria a seus filhos 'danificados'." Esta será, a propósito, a percepção clara de toda uma coletividade, abandonada à própria sorte, em "Uma antiga folha [daChina]" [março 1917]:

\footnotetext{
"Wie wird es werden?" fragen wir uns alle. "Wie lange werden wir diese Last und Qual ertragen? [...]. Uns Handwerkern und Geschäftsleuten ist die Rettung des Vaterlandes anvertraut; wir sind aber einer solchen Aufgabe nicht gewachsen; haben uns doch auch nie gerühmt dessen fähig zu sein. Ein Mißverständnis ist es und wir gehn daran zugrunde..274

- O que irá acontecer? - todos nós nos perguntamos. - Quanto tempo vamos suportar esse peso e tormento? [...]. A nós, artesãos e comerciantes, foi confiada a salvação da pátria; mas não estamos à altura de uma tarefa dessas, nem jamais nos vangloriamos de estar. É um equívoco e por causa dele vamos nos arruinar. ${ }^{275}$
}

\section{Durante a construção da Muralha da China}

Já em Durante a construção da Muralha da China [março 1917], assistimos - a partir também de um narrador que insistemente faz uso de um nós - ao espetáculo de um Estado que, com o objetivo alardeado de se defender contra ameaças externas - "Die Mauer war doch, wie allgemein verbreitet wird und bekannt ist, zum Schutz gegen die Nordvölker gedacht."/“Conforme em geral se propala e é sabido, a muralha foi pensada como proteção contra os povos do norte." ${ }^{276}$-, mobiliza sua população inteira em um empreendimento colossal, qual seja, o de cercar com uma muralha toda a "China infindável":

Die Mauer sollte ein Schutz für die Jahrhunderte werden, sorgfältigster Bau, Benützung der Bauweisheit aller bekannten Zeiten und Völker, dauerndes Gefühl der persönlichen

\footnotetext{
${ }^{274}$ F. Kafka, "Oktavheft C" ["Ein altes Blatt"], em KKA N1, p. 361, grifos meus.

${ }^{275}$ F. Kafka, "Um folha antiga", em Um médico rural, p. 26.

${ }^{276}$ F. Kafka, "Oktavheft C" [Beim Bau der chinesischen Mauer], em KKA N1, p. 338.
} 
Verantwortung der Bauenden waren deshalb unumgängliche Voraussetzungen für die Arbeit. [...]. Man war nicht leichtsinnig an das Werk herangegangen. Fünfzig Jahre vor Beginn des Baues hatte man im ganzen China, das ummauert werden sollte, die Baukunst, insbesondere das Mauerhandwerk zur wichtigsten Wissenschaft erklärt und alles andere nur anerkannt, soweit es damit in Beziehung stand. ${ }^{277}$

[...] a muralha devia tornar-se uma proteção por séculos; a construção mais cuidadosa, o uso de sabedoria arquitetônica de todos os tempos e povos conhecidos, o sentimento duradouro da responsabilidade pessoal dos que a faziam eram, por isso, o pressuposto indispensável para o trabalho. [...]. A construção não foi empreendida com leviandade. Cinqüenta anos antes do início, por toda China que devia ser cercada pela muralha, declarou-se a arquitetura, especialmente a alvenaria, como a mais importante das ciências, e tudo o mais só foi reconhecido na medida em que estava relacionado com isso. $^{278}$

Como nos lembra o próprio narrador-historiador, não se procedeu em sua execução de forma inconseqüente; pelo contrário, a "arte da construção ["Baukunst"], em especial a alvenaria ["Mauerhandwerk"]", foi calculadamente alçada quase à condição de "religião" de Estado: afinal "sobre as mãos do comando que desenhava os planos, caía pela janela o reflexo dos mundos divinos"/"durch das Fenster aber fiel der Abglanz der göttlichen Welten auf die Pläne zeichnenden Hände der Führerschaft"279. O resultado não é outro senão um Estado em que "corações e mentes" passam a gravitar em torno de um único propósito: a construção da muralha. Este "milagre da integração" ("Unidade! Unidade!”), porém, não demora a se revelar ilusório; para tanto basta notar como o "idílico" quadro de integração encobre em seus meandros um "espetáculo" sombrio e sangrento: refiro-me aqui ao macabro "espetáculo" da "ciranda do povo" ("Reigen des Volkes") na qual, como já mencionado antes, o sangue de todo conterrâneo ("jeder Landsmann") não mais fica encerrado em seus corpos, mas passa a se derramar "docemente", sem qualquer dúvida, uma das mais poderosas imagens deste escritor e que, diante do contexto europeu de mobilização e carnificina da Primeira Guerra Mundial, torna-se ainda mais espantosa ${ }^{280}$ :

${ }^{277}$ F. Kafka, "Oktavheft C" [Beim Bau der chinesischen Mauer], em KKA N1, p. 338-339.

${ }^{278}$ F. Kafka, Durante a construção da muralha da China, em NE, p. 74-75.

${ }^{279}$ F. Kafka, "Oktavheft C" [Beim Bau der Chinesischen Mauer], em KKA N1, p. 345 (trad. brasileira, p. 80).

${ }^{280}$ Cf. W. J. Mommsen, Die Urkatastrophe Deutschlands, p. 123-124:

Nas primeiras semanas da guerra, o entusiasmo nacional - que, sem dúvida, estava também ligado desde o princípio à dor da separação e à angústia diante das incertezas do futuro - havia determinado o comportamento da grande maioria dos soldados. As cenas de despedida nas estações de trens [...] transmitiam a impressão de unidade nacional [nationale Geschlossenheit] e firme vontade de vencer. [...]. Tudo isso evidentemente foi deixado de lado com as experiências do front; o que lá aconteceu nada mais tinha a ver com a típica imagem do soldado. Não se tratava mais de coragem e sacrifício desinteressado pela nação. Sob as condições da guerra de posição tratava-se menos de coragem e realização individual do que capacidade de sofrimento [Leidensfähigkeit] e força de resistência [Durchhaltevermögen] sob circunstâncias drasticamente adversas. [...]. Sob tais circunstâncias o tradicional discurso de combate pela grandeza da pátria e da morte sacrificial por uma grande Alemanha logo perdeu toda a sua credibilidade. 
[...] auf allen Wegen Grüße, Wimpel und Fahnen, niemals hatten sie gesehn wie groß und reich und schön und liebenswert ihr Land war, jeder Landsmann war ein Bruder, für den man eine Schutzmauer baute und der mit allem was er hatte und war sein Leben lang dafür dankte, Einheit! Einheit! Brust an Brust, ein Reigen des Volkes, Blut, nicht mehr eingesperrt im kärglichen Kreislauf des Körpers, sondern süß rollend und doch wiederkehrend durch das unendliche China. ${ }^{281}$

Em todos os caminhos, cumprimentos, flâmulas e bandeiras - nunca antes eles haviam visto como sua terra era grande e rica e bela e digna de ser amada. Todo conterrâneo era um irmão para o qual se construía uma muralha protetora e que por isso agradecia, com tudo o que tinha e era, pela vida inteira. Unidade! Unidade! Peito a peito, uma ciranda do povo, o sangue não mais encerrado na estreita circulação do corpo, mas rolando docemente e não obstante retornando pela China infindável. ${ }^{282}$

Para tal imagem, o comentário de Adorno de que "integração é desintegração e nela se encontram o encanto mítico e a racionalidade dominadora"283 revela-se bastante pertinente. Porém, para além ainda desta cena tenebrosa - mas, como vimos, cuidadosamente revestida por uma aura idílica -, inúmeros outros "ruídos" no relato histórico deste narrador contribuem ainda para minar a fachada pacificada, expondo assim a violência inerente ao processo de construção da Grande Muralha:

Gegen wen sollte die große Mauer schützen? Gegen die Nordvölker. Ich stamme aus dem südöstlichen China. Kein Nordvolk kann uns dort bedrohn. [...]. [...] gesehen haben wir sie nicht, und bleiben wir in unserm Dorfe, werden wir sie niemals sehn, selbst wenn sie auf ihren wilden Pferden geradeaus zu uns hetzen und jagen; zu groß ist das Land und läßt sie nicht zu uns, in die leere Luft werden sie sich verrennen. Warum also, da es sich so verhält, verlassen wir die Heimat, den Fluß und die Brücken, die Mutter und den Vater, das weinende Weib, die lehrbedürttigen Kinder und ziehen weg zur Schule nach der fernen Stadt und unsere Gedanken sind noch weiter bei der Mauer im Norden. Warum? Frage die Führerschaft. ${ }^{284}$

Contra quem devia nos proteger a grande muralha? Contra os povos do norte. Sou natural do sudeste da China. Lá nenhum povo do norte pode nos ameaçar. [...]. Não os vimos nunca e se permanecermos em nossa aldeia nunca os veremos, mesmo que eles se lancem em linha reta à nossa caça, montados nos seus cavalos selvagens - o país é grande demais e não os deixa chegar até nós: cavalgando, eles irão se perder no vazio. Por que então, uma vez que as coisas são assim, abandonamos o lar, o rio e as pontes,

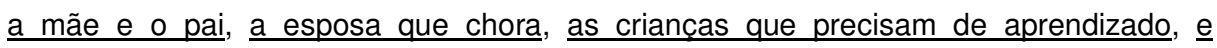

Portanto, não é por acaso, lembra-nos Mommsen, que desde o início de 1916 e definitivamente com os abatedouros de Verdun e Somme, o chamado "espírito de agosto de 1914" - a enorme euforia que tomou conta da maior parte da população - passou a se dissipar e dar lugar a uma desilusão crescente.

${ }^{281}$ F. Kafka, "Oktavheft C" [Beim Bau der chinesischen Mauer], em KKA N1, p. 342 (grifos meus).

${ }^{282}$ F. Kafka, Durante a construção da Muralha da China, em NE, p. 77-78 (tradução modificada).

${ }^{283}$ T.W. Adorno, "Anotações sobre Kafka", em Prismas, p. 253.

${ }^{284}$ F. Kafka, Beim Bau der chinesischen Mauer, em KKA N1, p. 346-347. 
partimos para a escola na cidade distante e os nossos pensamentos estão mais longe ainda, junto à muralha do norte? Por quê? Pergunte ao comando $^{285}$

Por fim, assinale-se ainda um trecho, quase ao final desta narrativa, que enterra ainda mais a idéia de uma "integração milagrosa", ao assinalar o fato de que muitos de seus "cidadãos" ("Bürger") não se mostram totalmente confortáveis neste Estado:

Ähnlich worden die Loute boi uns von staatlichen Umwälzungen I von zoitgenössischen Kriegen
in der Regel wenig betroffen. Ich erinnere mich hier an einen Vorfall aus meiner Jugend. In einer
benachbarten, abor immerhin sehr weit ontfornten Provinz, war oin Aufstand ausgobrochen, die
Ursachen sind mir nicht mehr orinnerlich, sie sind hier auch nicht wichtig, Ursachen für Aufstände orgoben sich dort mit jedem nouen Morgen, os ist oin aufgeregtes Volk. Und nun wurde oinmal oin Flugblatt der Aufständischen durch oinen Bettler, der jene Provinz durchreist hatte, in das Haus meines Vaters gebracht. Es war gerade ein Feiertag, Gäste füllten unsere Stube, in der Mitte sass der Priester und studierte das Blatt. Plötzlich fing alles zu lachen an, das Blatt wurde im Gedränge zerissen, der Bettler, der allerdings schon reichlich beschenkt worden war, wurde mit Stössen aus dem Zimmer gejagt, alles zerstroute sich und lief in den schönen Tag. Warum? Der Dialekt der Nachbarprovinz ist von dem unsern wesentlich verschieden und dies drückt sich auch in gowisson Formen der Schriftsprache aus, die für uns oinen otwas altertümlichen Charakter haben. Kaum hatte nun der Priester 2 derartige Sätze gelesen, war man schon ontschieden. Alte Dinge, längst gohört, längst vorschmerzt. Und trotzdem so schøint es mir in der Erinnerung aus dem Bettler das grauenhafte Leben unwiderleglich sprach, schüttelte man lachend den Kopf und wollte nichts mehr hören. So boreit ist man boi uns die Gegenwart auszulöschen. ${ }^{286}$

De maneira semelhante as pessoas entre nós são em regra pouco afetadas pelas revoluções de Estado e pelas guerras contemporâneas. Lembro-me aqui de um caso ocorrido na minha juventude. Numa província vizinha, mas assim mesmo muito distante, irrompeu um levante. Não me recordo mais das causas, aqui elas não têm importância. Causas para levantes se oferecem lá a cada nova manhã, trata-se de um povo agitado. Certa vez um mendigo que havia percorrido aquela província levou à casa de meu pai um panfleto dos revoltosos. Era justamente um dia de festa, os hóspedes enchiam nossos aposentos, no centro estava sentado o sacerdote, estudando o panfleto. De repente todos começaram a rir, no aperto o panfleto foi rasgado, o mendigo, que por certo já tinha sido fartamente presenteado, foi posto para fora da sala aos empurrões, todos se dispersaram e correram para desfrutar o belo dia. Por quê? $\underline{0}$ dialeto da província vizinha é essencialmente diverso do nosso e isso também se expressa em certas formas da linguagem escrita, que para nós têm um caráter arcaico. Então, mal o sacerdote tinha lido duas páginas assim, o assunto já estava decidido. Coisas antigas, ouvidas havia muito, muito tempo e havia muito tempo superadas. E no entanto - é o que me parece na lembrança - a vida pavorosa falou de forma irrefutável pelo mendigo, as pessoas sacudiram

${ }^{285}$ F. Kafka, Durante a construção da Muralha da China, em NE, p. 81-82.

${ }^{286}$ F. Kafka, "Oktavheft C" [Beim Bau der Chinesischen Mauer], em KKA N1 App, p. 298-299. 
sorrindo a cabeça e não quiseram ouvir mais nada. A tal ponto entre nós elas estão dispostas a pagar o presente. ${ }^{287}$

\section{"Uma antiga folha [da China]"}

Aus diesem stillen immer ängstlich rein gehaltenen Platz haben sie [die Nomaden] einen wahren Stall gemacht. Wir versuchen zwar manchmal aus unsern Geschäften hervorzulaufen und wenigstens den ärgsten Unrat wegzuschaffen, aber es geschieht immer seltener, denn die Anstrengung ist nutzlos [...].

(Franz Kafka, "Ein altes Blatt [aus China]", 1917)

E assim se chega ao cenário quase apocalíptico de "Uma antiga página [da-China]" [março 1917]. Na qual mais uma vez um narrador valendo-se de um nós apresenta as críticas condições de sua "pátria" ("Vaterland"). Repare para tanto na imagem da praça em frente ao palácio imperial tomada pelos nômades e cuja sujeira não pára de se acumular, a exemplo da água do esgoto da "monstruosa casa". A partir de uma "antiga folha da China" Kafka, contudo, apresentava-nos um quadro bastante atual e realista da "Áustria", a "China européia".

${ }^{287}$ F. Kafka, Durante a construção da Muralha da China, em NE, p. 88-89.

${ }^{288}$ F. Kafka, "Oktavheft C" ["Ein altes Blatt [aus China]"], em KKA N1, p. 358-359. Trad. de Modesto Carone (F. Kafka, "Uma folha antiga", em MR, p. 24): "[Os nômades] Fizeram desta praça tranqüila, mantida sempre escrupulosamente limpa, uma autêntica estrebaria. É verdade que nós tentamos às vezes sair às pressas das nossas lojas para retirar pelo o grosso da sujeira, mas isso ocorre com uma freqüência cada vez menor [...]." 


\title{
CAPÍTULO 3 \\ Reflexões sobre a "China européia"
}

\author{
Im Grunde bin ich ja ein Chinese [...]. \\ (Franz Kafka, Carta a Felice Bauer, 1916) ${ }^{289}$ \\ Keine menschliche Kunst erscheint bei Kafka so tief \\ kompromittiert wie die Baukunst. Keine ist lebenswichtiger \\ und vor keiner macht die Ratlosigkeit sich vernehmbarer. \\ (Beim Bau der Chinesischen Mauer, "Das Stadtwappen", \\ "Der Bau”)
}

(Walter Benjamin, 1934) ${ }^{290}$

\section{Arquitetura fragmentária}

A rigor, Durante a construção da Muralha da China deixa-se desmembrar em dois grandes "blocos" narrativos ligados de maneira um tanto frouxa por um pequeno parágrafo que acaba funcionando como uma espécie de pequeno bloco de transição.

No primeiro bloco narrativo, as reflexões do narrador tratam especificamente do processo de construção da Muralha da China, cujo desenho final se aparenta a uma linha tracejada. O construtor-historiador chinês anuncia a conclusão da muralha em seu trecho mais setentrional, discorre sobre os métodos utilizados no processo de construção e busca uma explicação para o que considera a "questão nuclear de toda a construção da muralha", ou seja, o "sistema de construção por partes". Neste primeiro bloco, as figuras do império e do imperador estão completamente ausentes.

Já no segundo bloco as reflexões do narrador voltam-se para uma das instituições mais obscuras do povo chinês: o império (e, conseqüentemente, para a figura do imperador). A partir deste ponto, a muralha passa a um segundo plano, não sendo mais sequer mencionada; de forma análoga, a figura do "comando" (“Führung”/“Führerschaft”) ou "comando supremo" ("oberste Führerschaft") ${ }^{291}$, responsável pela organização do

\footnotetext{
${ }^{289}$ F. Kafka, Briefe an Felice, p. 657: Em essência eu sou mesmo um chinês [...].

${ }^{290}$ W. Benjamin, "Aufzeichnungen" (bis Juni 1934), em Benjamin über Kafka, p. 146: "Nenhuma arte humana aparece em Kafka tão profundamente comprometida como a arquitetura [Baukunst = literalmente, arte da construção]. Nenhuma tem mais importância vital e perante nenhuma outra a desorientação se faz mais perceptível. (Durante a construção da Muralha da China, 'O brasão da cidade', 'A construção')"

291 Instância anônima e indeterminada: "o comando existiu desde sempre, bem como a decisão de construir a muralha".
} 
trabalho nesta sociedade, também desaparece por completo do horizonte investigativo do narrador.

Em ambos os blocos narrativos, portanto, deparamo-nos com "construções interrompidas": seja a muralha chinesa fragmentária ou descontínua (primeiro bloco), seja o império chinês, caracterizada pela fratura entre imperador e povo (cf. ainda Uma mensagem imperial, pequena narrativa localizada logo no início deste "segundo bloco": o narrador refere-se a ela como "lenda"/"Sage" e a utiliza com a intenção de ilustrar a complexa e descontínua relação entre imperador e povo ${ }^{292}$ ).

O pequeno bloco de transição não consegue, todavia, ocultar esta quebra que se mantém de modo sensível (a transição acaba assim se efetuando de forma um tanto frouxa):

\begin{abstract}
Ich habe mich, schon teilweise während des Mauerbaues und nachher bis heute fast ausschließlich mit vergleichender Völkergeschichte beschäftigt - es gibt bestimmte Fragen denen man nur mit diesem Mittel gewissermaßen an den Nerv herankommt - und ich habe dabei gefunden, daß wir Chinesen gewisse volkliche und staatliche Einrichtungen in einzigartiger Klarheit, andere wieder in einzigartiger Unklarheit besitzen. Den Gründen insbesondere der letztern Erscheinung nachzuspüren, hat mich immer gereizt, reizt mich noch immer und auch der Mauerbau ist von diesen Fragen wesentlich betroffen. ${ }^{293}$

Já durante a construção da muralha, e depois até hoje, eu me ocupei quase que exclusivamente com a história comparada dos povos - há certas questões a cujo nervo, por assim dizer, só se chega por esse meio - e com isso descobri que nós, chineses, possuímos certas instituições populares e estatais de uma clareza sem par, e outras, por seu turno, de uma falta de clareza única. Rastrear os motivos principalmente do último fenômeno sempre me atraiu e continua atraindo; também a construção da muralha está essencialmente afetada por essas questões. $^{294}$
\end{abstract}

Estrutura fragmentária da narrativa: a narrativa acaba assim vítima de sua coerência implacável (narrativa rigorosamente construída). A má infinitude do figurado em ambos os blocos narrativos - seja a muralha fragmentária (a tarefa de cercar uma China qualificada como infinita é, por natureza, inacabável) seja a estrutura deficitária da instituição do império (incapaz de se fazer compreensível e acessível ao povo) - acaba contaminando a estrutura mais íntima da narrativa (que, por sua vez, desdobra-se produzindo uma

292 Cf. F. Kafka, "Oktavheft C" [Beim Bau der chinesischen Mauer], em KKA N1, p. 352: "Genau so, so hoffnungslos und hoffnungsvoll sieht unser Volk den Kaiser"./"Exatamente assim, tão sem esperança e esperançoso, o nosso povo vê o imperador." (F. Kafka, Durante a construção da Muralha da China, em NE, p. 87.)

${ }^{293}$ F. Kafka, "Oktavheft C" [Beim Bau der chinesischen Mauer], em KKA N1, p. 348.

${ }^{294}$ F. Kafka, Durante a construção da Muralha da China, em NE, p. 83. 
infinidade de figuras da descontinuidade e do descompasso; cf., por exemplo, a própria narrativa contida em seu cerne Uma mensagem imperial).

A exemplo de outros textos kafkianos, trata-se de uma narrativa carregada de ambigüidades e construída de modo sinuoso e descontínuo. Este traçado vicioso da composição decorre do próprio caráter errático e conjectural das reflexões do narrador, emperrando assim a progressão narrativa. Sob este aspecto, a não-linearidade da narrativa parece mesmo mimetizar as "construções interrompidas" explicitadas pelo texto.

\section{A figura do narrador}

O fragmento é narrado do ponto de vista de um dos antigos construtores da grande muralha. Discurso errático do narrador (um discurso que segue o acaso): testemunho da desorientação do próprio narrador nesta vasta engrenagem. Não se trata porém de um simples mestre-de-obras, já que este narrador acaba também por se ocupar da "história comparada dos povos", vindo então a descobrir a existência de "instituições populares e estatais de uma clareza sem par, e outras, de uma falta de clareza única". Estas últimas passam a ser então o objeto de pesquisa deste historiador (segundo bloco narrativo). Nesse sentido, a narrativa como um todo assume a feição de uma "investigação histórica" (ou de um "relato histórico") movida no sentido de buscar, inicialmente, uma explicação para a "construção por partes" (para assim resgatar e expor as experiências daquele tempo histórico, como o próprio narrador anuncia) e, em seguida, rastrear as razões da obscuridade de uma daquelas "instituições mais obscuras", o império:

Dadurch also wird das System des Teilbaues verständlich, aber es hatte doch wohl noch andere Gründe. Es ist auch keine Sonderbarkeit, daß ich mich bei dieser Frage solange aufhalte, es ist eine Kernfrage des ganzen Mauerbaues, so unwesentlich sie zunächst scheint. Will ich den Gedankenkreis und die Erlebnisse jener Zeiten vermitteln und begreiflich machen, kann ich gerade dieser Frage nicht genug tief nachbohren. ${ }^{295}$

Assim portanto fica compreensível o sistema de construção por partes; mas por certo ele ainda tinha outras razões. Não é nada estranho também que eu me detenha tanto tempo nesta questão: por mais inessencial que a princípio pareça, ela é a questão nuclear de toda a construção da muralha. Se quero transmitir e tornar inteligíveis o pensamento e as experiências daquele tempo, então não posso deixar de me aprofundar o suficiente justamente nesta questão. ${ }^{296}$

\footnotetext{
${ }^{295}$ F. Kafka, "Oktavheft C" [Beim Bau der chinesischen Mauer], em KKA N1, p. 342.

${ }^{296}$ F. Kafka, Durante a construção da Muralha da China, em NE, p. 78.
} 
Meine Untersuchung ist doch nur eine historische, aus den längst verflogenen Gewitterwolken zuckt kein Blitz mehr und ich darf deshalb nach einer Erklärung des Teilbaues suchen $[\ldots]^{297}$

Certamente minha pesquisa é apenas histórica; das nuvens de tempestade há muito tempo desaparecidas não se descarrega mais nenhum raio, e por isso posso buscar uma explicação para a construção por partes [... ${ }^{298}$

Ich habe mich, schon teilweise während des Mauerbaues und nachher bis heute fast ausschließlich mit vergleichender Völkergeschichte beschäftigt - es gibt bestimmte Fragen denen man nur mit diesem Mittel gewissermaßen an den Nerv herankommt und ich habe dabei gefunden, daß wir Chinesen gewisse volkliche und staatliche Einrichtungen in einzigartiger Klarheit, andere wieder in einzigartiger Unklarheit besitzen. Den Gründen insbesondere der letztern Erscheinung nachzuspüren, hat mich immer gereizt, reizt mich noch immer und auch der Mauerbau ist von diesen Fragen wesentlich betroffen. ${ }^{299}$

Já durante a construção da muralha, e depois até hoje, eu me ocupei quase que exclusivamente com a história comparada dos povos - há certas questões a cujo nervo, por assim dizer, só se chega por esse meio - e com isso descobri que nós, chineses, possuímos certas instituições populares e estatais de uma clareza sem par, e outras, por seu turno, de uma falta de clareza única. Rastrear os motivos principalmente do último fenômeno sempre me atraiu e continua atraindo; também a construção da muralha está essencialmente afetada por essas questões. ${ }^{300}$

O narrador manifesta assim explicitamente a finalidade de seu "relato" (no primeiro "bloco narrativo"), qual seja, "transmitir e tornar inteligíveis o pensamento e as experiências daquele tempo" (portanto, do tempo durante o qual a muralha foi construída). O que mais chama a atenção, no entanto, é o modo como este narrador kafkiano pretende resgatar as "experiências daquele tempo", ou seja, a partir da análise do princípio de construção desta vasta construção. Para este, o acesso àquelas experiências históricas implica o mergulho nesta que é a sua questão nuclear: o "sistema de construção por partes" ("Não é nada estranho também que eu me detenha tanto tempo nesta questão: por mais inessencial que a princípio pareça, ela é a questão nuclear de toda a construção da muralha."). A formulação é portanto bastante arrojada; dito de outro modo, aquele tempo

${ }^{297}$ F. Kafka, "Oktavheft C" [Beim Bau der chinesischen Mauer], em KKA N1, p. 346.

${ }^{298}$ F. Kafka, Durante a construção da Muralha da China, em NE, p. 81.

${ }^{299}$ F. Kafka, "Oktavheft C" [Beim Bau der chinesischen Mauer], em KKA N1, p. 348.

${ }^{300}$ F. Kafka, Durante a construção da Muralha da China, em NE, p. 83. 
histórico (as "experiências daquele tempo") estaria contido no princípio de construção por partes. ${ }^{301}$

Além disso, o construtor-historiador chinês parece intuir o parentesco entre a estrutura da muralha e a estrutura de instituições de sua sociedade; chamando assim a atenção para o dado de que as correlações entre os métodos de construção da muralha (bem como a sua configuração fragmentária final) e as "instituições populares e estatais" desta sociedade não são casuais (cf. o bloco de transição: "[...] também a construção da muralha está essencialmente afetada por essas questões"), mas articuladas pelo "espírito do tempo" ("Geist der Zeit"). A época, o tempo histórico da construção da muralha (ou seja, o seu "Geist der Zeit") acaba por se manifestar não apenas na estrutura da vasta muralha chinesa mas também, e sintomaticamente, na estrutura política do império (cuja estrutura descontínua, aliás, o próprio narrador enfatiza). Às voltas com descontinuidades de toda espécie (sejam métodos - ou "planos nebulosos" - de construção sejam instituições obscuras - como o império), o narrador-historiador busca assim explicitar nexos (os nexos entre "diferentes" descontinuidades); enfim, aquilo que ligaria estas descontinuidades. Os esforços deste narrador nesse sentido permanecem, todavia, fragmentários, a exemplo dos muitos fragmentos da muralha.

\section{A organização da vida e do trabalho}

Cf. W. Benjamin, "Franz Kafka: a propósito do décimo aniversário de sua morte”, em Magia e técnica, arte e política, p. 148: "De qualquer maneira, trata-se da questão da organização da vida e do trabalho na comunidade humana. Essa questão preocupou Kafka como nenhuma outra e era impenetrável para ele. [...]. A organização está constantemente presente em Kafka, não somente nas gigantescas hierarquias de funcionários, em $O$ processo e $O$ castelo, mas de modo ainda mais tangível nos incompreensíveis projetos de construção, descritos em $A$ muralha da China." Cf. também A. Rosenfeld, "Kafka e o romance moderno", em Letras e leituras, p. 62: "Em Kafka e no romance em geral, exprime-se intensamente a experiência da alienação."

O quadro social exposto pelo construtor-historiador chinês é de uma "monstruosa" estratificação, com inumeráveis segmentos sociais segundo um princípio hierárquico: com relação à organização do trabalho durante a construção da muralha (primeiro bloco) vislumbra-se diferentes níveis de trabalhadores e construtores: os trabalhadores diaristas,

${ }^{301}$ Cf. F. Kafka, "Oktavheft C" [Beim Bau der chinesischen Mauer], em KKA N1, p. 340: "Ein winziger Vorfall, aber bezeichnend für den Geist der Zeit."/“Um incidente minúsculo, mas significativo para o espírito da época." (F. Kafka, Durante a construção da Muralha da China, em NE, p. 75.) 
os mestres-de-obras de nível inferior, os de nível médio, os mestres-de-obras mais altos e acima destes a figura do "comando supremo", instância superior e indeterminada; já com relação à organização social e política do império: o povo (súditos), professores das escolas inferiores, "professores de direito público e história nas escolas superiores", os círculos da corte, a figura do imperador (segundo bloco). Sem dúvida, "[...] a imagem dos poderes superiores, que parecem simbolizar a ordem, é a de um labirinto, de uma engrenagem burocrática que é a exata representação do nosso mundo alienado, com sua organização gigantesca totalmente desumanizada [...]"302.

Construção que, "ao menos para o indivíduo isolado, não pode ser verificada com os próprios olhos e segundo um critério pessoal, em virtude da sua dimensão"303. As gigantescas dimensões da grande muralha - compatíveis, todavia, com as dimensões de uma "China infinita" - impossibilitam o "homem isolado" de abarcar o conjunto da construção. Considerando-se, contudo, as dimensões do país que deveria ser cercado por esta muralha, esta última mostrar-se-á sempre insuficiente, pois estamos diante de uma China "infinita": "Nosso país é tão grande que nenhuma lenda dá conta do seu tamanho, o céu é quase incapaz de cobri-lo."304

A alardeada "Unidade! Unidade!" (“Einheit! Einheit!") ${ }^{305}$ exclamada pelo narrador soa deslocada e entra mesmo em flagrante contradição com o quadro da organização do trabalho descrito; a exclamação mostra-se ainda mais problemática na medida em que se insere num contexto da mais absoluta estratificação (basta pensar, por exemplo, na descrição da extensa hierarquia dos trabalhadores da muralha; esta "Unidade! Unidade!" destoa também do "sistema de construção por partes" e da própria figura final da muralha, no caso uma muralha descontínua ou um conjunto de "muralhas parciais"). Trata-se enfim de unidade imaginária destinada, ao que tudo indica, a encobrir as fraturas desta sociedade complexa e altamente especializada na qual o narrador se insere ${ }^{306}$ :

[...] alles dieses besänftigte ihre Ungeduld, das ruhige Leben der Heimat in der sie einige Zeit verbrachten kräftigte sie, das Ansehen in dem alle Bauenden standen, die gläubige Demut, mit der ihre Berichte angehört wurden, das Vertrauen, das der einfache stille Bürger in die einstige Vollendung der Mauer setzte, alles dieses spannte die Saiten der Seele, wie ewig hoffende Kinder nahmen sie von der Heimat Abschied, die Lust wieder am Volkswerk zu arbeiten wurde unbezwinglich, sie reisten früher von zuhause fort als es nötig gewesen wäre, das halbe Dorf begleitete sie

\footnotetext{
${ }^{302}$ A. Rosenfeld, "Kafka e o romance moderno", em Letras e leituras, p. 61.

${ }^{303}$ F. Kafka, Durante a construção da Muralha da China, em NE, p. 74.

${ }^{304}$ F. Kafka, Durante a construção da Muralha da China, em NE, p. 84.

${ }^{305}$ F. Kafka, "Oktavheft C" [Beim Bau der chinesischen Mauer], em KKA N1, p. 342.

${ }^{306}$ Cf. T. W. Adorno, Prismas, p. 22: "[...] quanto mais o mundo possui a aparência de unidade e totalidade, maior é o avanço da reificação e, portanto, da divisão."
} 
lange Strecken weit, auf allen Wegen Grüße, Wimpel und Fahnen, niemals hatten sie gesehn wie groß und reich und schön und liebenswert ihr Land war, jeder Landsmann war ein Bruder, für den man eine Schutzmauer baute und der mit allem was er hatte und war sein Leben lang dafür dankte, Einheit! Einheit! Brust an Brust, ein Reigen des Volkes, Blut, nicht mehr eingesperrt im kärglichen Kreislauf des Körpers, sondern süß rollend und doch wiederkehrend durch das unendliche China. ${ }^{307}$

Tudo isso apaziguava sua impaciência. A vida calma da terra natal onde passavam algum tempo fortalecia-os; o prestígio de que gozavam todos os construtores, a crédula humildade com que eram ouvidos os seus relatos, a confiança que o cidadão simples e tranqüilo depositava na antiga construção da muralha - tudo isso esticava as cordas da alma. Como crianças eternamente esperançosas eles se despediam então da terra natal, o desejo de trabalhar outra vez na obra do povo havia se tornado invencível. Partiam de casa mais cedo do que teria sido necessário, a metade da aldeia os acompanhava durante longos trechos. Em todos os caminhos, grupos, flâmulas, bandeiras - nunca antes eles haviam visto como sua terra era grande e rica e bela e digna de ser amada. Cada conterrâneo era um irmão para o qual se construía uma muralha protetora e que por isso agradecia, com tudo o que tinha e era, pela vida inteira. Unidade! Unidade! Peito a peito, uma ciranda do povo, o sangue não mais encerrado na estreita circulação do corpo, mas rolando docemente e não obstante retornando pela China infindável. ${ }^{308}$

Visto por este ângulo, o processo de "esticar as cordas da alma" assume tons sombrios, ocultando sofisticadas técnicas de manipulação. Resta ao final a imagem de um mundo totalmente administrado, "mundo em que a totalidade social, mediante sofisticados processos de intervenção na economia psíquica dos indivíduos, retira-lhes a capacidade de se determinar no mais ínfimo detalhe de sua vida pessoal’309:

Gegen wen sollte die große Mauer schützen? Gegen die Nordvölker. Ich stamme aus dem südöstlichen China. Kein Nordvolk kann uns dort bedrohn. [...]. Aber mehr wissen wir von diesen Nordländern nicht, gesehen haben wir sie nicht, und bleiben wir in unserm Dorfe, werden wir sie niemals sehn, selbst wenn sie auf ihren wilden Pferden geradeaus zu uns hetzen und jagen; zu groß ist das Land und läßt sie nicht zu uns, in die leere Luft werden sie sich verrennen. Warum also, da es sich so verhält, verlassen wir die Heimat, den Fluß und die Brücken, die Mutter und den Vater, das weinende Weib, die lehrbedürftigen Kinder und ziehen weg zur Schule nach der fernen Stadt und unsere Gedanken sind noch weiter bei der Mauer im Norden. Warum? Frage die Führerschaft. ${ }^{310}$

\footnotetext{
${ }^{307}$ F. Kafka, "Oktavheft C" [Beim Bau der chinesischen Mauer], em KKA N1, p. 341-342.

${ }^{308}$ F. Kafka, Durante a construção da Muralha da China, em NE, p. 77-78.

${ }^{309}$ R. Duarte, "Morte da imortalidade: Adorno e o prognóstico hegeliano da morte da arte", em Adornos: nove ensaios sobre o filósofo frankfurtiano, p. 126. Cf. também E. Canetti, O outro processo, p. 87: "Entre todos os escritores, Kafka é o maior experto, no que toca ao poder. Experimentou e configurou todas as facetas dele."

${ }^{310}$ F. Kafka, "Oktavheft C" [Beim Bau der chinesischen Mauer], em KKA N1, p. 346-347.
} 


\begin{abstract}
Contra quem devia nos proteger a grande muralha? Contra os povos do norte. Sou natural do sudeste da China. Lá nenhum povo do norte pode nos ameaçar. [...]. Não os vimos nunca e se permanecermos em nossa aldeia nunca os veremos, mesmo que eles se lancem em linha reta à nossa caça, montados nos seus cavalos selvagens - o país é grande demais e não os deixa chegar até nós: cavalgando, eles irão se perder no vazio. Por que então, uma vez que as coisas são assim, abandonamos o lar, o rio e as pontes, a mãe e o pai, a esposa que chora, as crianças que precisam de aprendizado, e partimos para a escola na cidade distante e os nossos pensamentos estão mais longe ainda, junto à muralha do norte? Por quê? Pergunte ao comando. ${ }^{311}$
\end{abstract}

\title{
A Monarquia do Danúbio como "China européia"
}

Paralelo entre Áustria (Monarquia do Danúbio) e China já traçado, por exemplo, pelo escritor austríaco Franz Grillparzer no século XIX (escritor considerado por Kafka um de seus "parentes de sangue", como ele próprio assinala em carta a Felice Bauer).

Pertinência histórica entre a fundação do Império Chinês e a construção da Muralha da China. Ao conquistar o último dos reinos independentes em 221 a.C. o rei Zheng, do reino de Qin, encerrava uma conturbada e sangrenta época da história chinesa conhecida como "Período dos reinos combatentes" (que, a seu turno, havia se iniciado por volta de 403 a.C. com o declínio político da Dinastia Zhou) e passava a reinar sobre uma "China" unificada; dando assim início a uma configuração política que haveria de se manter, com breves interrupções e alterações territoriais, até 1911 (portanto, por mais de dois milênios!), qual seja, o Império Chinês: "Com as vitórias de Qin sobre todos os seus rivais, a China se tornou um grande império agrário. A monarquia burocrática centralizada, a forma de governo que caracterizaria quase todo o restante da história chinesa, foi criada pela Dinastia Qin (que governaria toda a China de 221 a 206 a.C.) e consolidada durante a muito mais longa Dinastia Han (202 a.C.-206 d.C.)." ${ }^{312}$ Para se destacar dos antigos reis do "Período dos reinos combatentes" e reforçar seu novo status, Zheng tomou para si um novo título: Shi Huangdi ("Primeiro Imperador" ou, literalmente, "imperador que começa"); daí portanto Qin Shi Huangdi - ou seja, "Primeiro Imperador de Qin" - já que o nome oficial do reino recém-unificado continuava Qin. Responsável pela unificação política da China, o imperador Qin Shi Huangdi também unificou a língua chinesa, impôs um único sistema de pesos e medidas para todo o estado e promoveria ainda a ligação das fortificações existente ao norte da China, o que acabaria dando início à chamada

\footnotetext{
${ }^{311}$ F. Kafka, Durante a construção da Muralha da China, em NE, p. 81-82.

${ }^{312}$ P. B. Ebrey, History of China, p. 60.
} 
Grande Muralha. ${ }^{313}$ Historicamente portanto a construção do que viria a ser conhecido como a Grande Muralha co-incide com a fundação do próprio Império Chinês! Ignoro se Kafka atentou para este dado, sem dúvida, extraordinário/notável; a se considerar a própria estrutura de Durante a construção da Muralha da China é de se acreditar que sim: para fins de análise propomos neste trabalho a divisão deste fragmento de narrativa em dois blocos: no primeiro deles, o narrador concentra-se apenas no processo de construção da Grande Muralha (o historiador chinês faz inúmeras referências a um "comando supremo" ["oberste Führerschaft"]; repare que curiosamente não há uma menção sequer à figura do imperador); já em um segundo momento de seu relatório, o narrador-historiador direciona suas investigações para a "instituição do império" ["Institution des Kaisertums"], neste momento a Grande Muralha desaparece por completo de seu horizonte.

Cabe ressaltar também que a espetacular muralha se ergue na "longínqua" China, portanto, neste "domínio no Oriente" (significado etimológico de "Ostarrîchi" = "Österreich", ou seja, Áustria):

\footnotetext{
"Ostarrîchi" é a mais antiga forma conservada do nome "Österreich" (Áustria) e aparece em um documento datado de 1.11.996; o qual registra a doação, por parte do imperador Otto III ao bispo Gottschalk de Freising, da propriedade "Niuuanhova" ("Neuhofen an der Ybbs"), "in regione vulgari vocabulo Ostarrîchi" ("na região chamada em língua vulgar de Ostarrîchi”). Etimologicamente, o termo significa "domínio no Oriente"; em 998 a palavra aparecerá grafada como "Osterrîche" e posteriormente também como "Osterlant". 314
}

Não bastasse a sintomática referência à China, não custa assinalar outro indício de que o escritor ao situar sua narrativa no "longínquo" império do meio mirava o seu próprio tempo e o seu próprio "país"315: o esboço de uma carta de Kafka a Fritz Lampl em resposta a um convite para participar de uma associação (Vereinigung) que consta no manuscrito kafkiano imediatamente antes de Durante a construção da Muralha da China: recusa kafkiana a uma“Grande-Áustria”/“Groß-Österreich”. A ironia da situação não

\footnotetext{
${ }^{313}$ Cf. P. B. Ebrey, History of China, p. 61.

${ }^{314}$ Informações extraídas do Österreich-Lexicon em http://www.aeiou.at/aeiou.encyclop.

${ }^{315}$ Fica difícil não lembrar do conhecido enunciado machadiano: "O que se deve exigir do escritor, antes de tudo, é certo sentimento íntimo, que o torne homem do seu tempo e do seu país, ainda quando trate de assuntos remotos no tempo e no espaço." Como porém as coisas nunca são fáceis em se tratando deste escritor, vale ressaltar que este "país" no caso de Kafka comporta ainda uma série de mediações, pois, oficialmente, estamos diante de um escritor que nasce cidadão austríaco e morre tchecoslovaco; sendo que o próprio escritor no entanto referiu-se a si mesmo mais de uma vez como boêmio-alemão (cf. nesse sentido o ensaio "Patriot ohne Vaterland" de Hans-Gerd Koch).
} 
escapou por certo ao "olhar mau" ("böser Blick") ${ }^{316}$ do escritor: afinal, em um momento em que a velha Monarquia do Danúbio se dirigia a todo vapor rumo ao colapso, como podia ainda alguém falar em uma "Grande-Áustria" ("Groß-Österreich") ou, em outros termos, como alguém podia ainda falar de um morto como se este ainda estivesse vivo?:

\begin{abstract}
Kommt einmal, einmal in einem Menschenalter, ein kaiserlicher Beamter, der die Provinz bereist, zufällig in unser Dorf, stellt im Namen des Regierenden irgendwelche Forderungen, prüft die Steuerlisten, wohnt dem Schulunterrichte bei, befragt den Priester über unser Tun und Treiben und faßt dann alles, ehe er in seine Sänfte steigt, zu langen Ermahnungen an die herbeigetriebene Gemeinde zusammen, dann geht ein Lächeln über alle Gesichter, einer blickt verstohlen zum andern, man beugt sich zu den Kindern herab, um sich vom Beamten nicht beobachten zu lassen. Wie, denkt man, er spricht von einem Toten wie von einem Lebendigen, dieser Kaiser ist doch schon längst gestorben, die Dynastie ausgelöscht, der Herr Beamte macht sich über uns lustig, aber wir tun so als ob wirs nicht merkten, um inn nicht zu kränken. ${ }^{317}$

Se uma vez, uma vez numa existência, um funcionário imperial que percorre a província chega por casualidade à nossa aldeia, levanta certas exigências em nome dos governantes, examina as listas de impostos, assiste às aulas na escola, interroga o sacerdote sobre nossas atividades e depois, antes de subir à sua liteira, resume tudo em longas admoestações à comunidade convocada, aí então um sorriso atravessa todos os rostos, um olha dissimuladamente para o outro e se inclina para as crianças a fim de não ser observado pelo funcionário. Como - é o que se pensa - ele fala de um morto como se fosse uma pessoa viva? Esse imperador já morreu há muito tempo, a dinastia extinta, o senhor funcionário faz troça de nós, mas agimos como se não o notássemos para não melindrá-lo. ${ }^{318}$
\end{abstract}

De modo análogo aos habitantes da aldeia chinesa, Kafka se comportou em sua polida resposta, a fim de não melindrar o seu interlocutor:

Trotzdem muß ich mich zurückhalten, ich bin nämlich nicht imstande, mir ein im Geiste irgendwie einheitliches Groß-Österreich klarzumachen und noch weniger allerdings, mich diesem Geistigen ganz eingefügt zu denken, vor einer solchen Entscheidung schrecke ich zurück.

316 Cf. F. Kafka, "Siebtes Heft" [06.08.1914], KKA T, p. 546-547: "Patriotischer Umzug. Rede des Bürgermeisters. Dann Verschwinden, dann Hervorkommen und der deutsche Ausruf: 'Es lebe unser geliebter Monarch, hoch.' Ich stehe dabei mit meinem bösen Blick. Diese Umzüge sind eine der widerlichsten Begleiterscheinungen des Krieges." "Manifestação patriótica. Discurso do prefeito. [...]. Eu fico em pé junto a isso (fico parado em meio a isso) com o meu olhar mau. Estas manifestações são uma das manifestações secundárias mais repulsivas da guerra."

${ }^{317}$ F. Kafka, "Oktavheft C" [Beim Bau der chinesischen Mauer], em NSF I, KKA, p. 353-354.

${ }^{318}$ F. Kafka, Durante a construção da Muralha da China, em Narrativas do espólio, p. 87-88. 
Nun ergibt sich aber daraus für Ihre Vereinigung kein Verlust, im Gegenteil. Ich bin organisch gar nicht befähigt, meine Personenkenntnis ist gering, irgendwie maßgebenden Einfluß habe ich nicht. Meine Beteiligung täte Ihnen also bald leid.

Sollte, wie es sich vielleicht nicht verhindern lassen wird, aus der Kunsthalle ein Verein werden mit Mitgliedsbeiträgen u. s. w. trete ich gern bei.

Nehmen Sie mir bitte meine Absage nicht übel, sie ist mir eine Notwendigkeit.

In ausdrücklicher Hochachtung ${ }^{319}$

Apesar disso, eu terei que recusar, eu não sou capaz de esclarecer para mim mesmo uma Grande-Áustria [Groß-Österreich] de algum modo espiritualmente unitária e ainda menos, aliás, de me imaginar completamente inserido neste estado de espírito; perante uma tal decisão eu recuo. [...].

Por favor, não leve a mal minha recusa, ela é para mim uma necessidade.

Com a mais expressa consideração

${ }^{319}$ F. Kafka, "Oktavheft C" [esboço de uma carta a Fritz Lampl], em NSF I, KKA, p. 336-337. 


\title{
CONSIDERAÇÕES FINAIS
}

\author{
Das Pferd des Angreifers zum eigenen Ritt benützen. \\ Einzige Möglichkeit. Aber was für Kräfte und \\ Geschicklichkeiten verlangt das? Und wie spät ist es \\ schon!
}

(F. Kafka, Tagebücher, 09.03.1922) $^{320}$

Vielleicht gibt es auch ein anderes Schreiben, ich kenne nur dieses; in der Nacht, wenn mich die Angst nicht schlafen läßt, ich kenne nur dieses. Und das Teuflische daran scheint mir sehr klar.

(F. Kafka, Carta a Max Brod, 05.07.1922) ${ }^{321}$

Em seu belo ensaio sobre Kafka, Walter Benjamin anotou:

Em seu testamento, [Kafka] ordenou que ela [sua produção] fosse destruída. Esse testamento, que nenhum estudo sobre Kafka pode ignorar, mostra que o autor não estava satisfeito; que ele considerava seus esforços malogrados; que ele se incluía entre os que estavam condenados ao fracasso. ${ }^{322}$

Não compartilho inteiramente, contudo, deste comentário de Benjamin. Em primeiro lugar, lembre-se que estamos diante de um escritor que, em inúmeras ocasiões, destruiu de fato muito de sua produção. ${ }^{323}$ Que muitos dos escritos de Kafka tenham chegado até nós é algo, portanto, que fala por si; afinal, não há razões para se duvidar de que se o escritor tivesse realmente pretendido a destruição de seu espólio, ele mesmo teria levado a cabo esta tarefa. Assim sendo, os dois famosos bilhetes deixados por Kafka solicitando a destruição de seu espólio precisam ser lidos, no mínimo, com desconfiança. Além disso, também não se deve perder de vista que este mesmo escritor chegou certa vez a afirmar:

\footnotetext{
${ }^{320}$ F. Kafka, "Zwölftes Heft", em KKA T, p. 910: "Utilizar o cavalo do agressor para a própria cavalgada. Única possibilidade. Mas que forças e habilidades isso exige? E como já está tarde!"

${ }^{321}$ F. Kafka, Briefe 1902-1924, p. 384-385: "Talvez também exista outra escrita, eu conheço apenas esta; durante a noite, quando a angústia não me deixa dormir, eu conheço apenas esta. E o diabólico nisso se afigura a mim bastante claro."

${ }^{322}$ W. Benjamin, "Franz Kafka: a propósito do décimo aniversário de sua morte", em Magia e técnica, arte e política, p. 154.

${ }^{323}$ Cf. a este respeito a oitava nota de rodapé de nosso primeiro capítulo. Lembre-se também que Dora Diamant, com quem Kafka morou em Berlim entre o final de 1923 e início de 1924, queimou a pedido do próprio escritor muitos de seus escritos desta época. Se recordamos que a poderosa narrativa $\underline{A \text { construção }}$ data precisamente deste período, podemos ter uma idéia do que talvez tenha sido destruído.
} 
Meine Selbstverurteilung hat zwei Ansichten, einmal ist sie Wahrheit [...] aber ist die Selbstverurteilung unvermeidlich auch Methode [...]. ${ }^{324}$

Minha auto-condenação tem dois lados, por um lado ela é verdade [...] mas a autocondenação é também inevitavelmente método [...].

Um tal comentário nos obriga portanto a encarar muito de sua autocondenação ou autodepreciação sob a ótica da encenação, da astúcia, da estratégia.

Isto posto, atente-se para o fato de que foi um entendimento radical de quão "malogrados" eram os seus esforços e de como eles pareciam inevitavelmente "condenados ao fracasso" o que permitiu a este escritor talvez a maior de suas façanhas literárias: assumir visceralmente o "fracasso" como ponto de partida e pressuposto de sua forma, tornando-se assim capaz de operar no limiar entre a semidestruição e o semiacabamento. E também não se esqueça de que este novo modo de conceber a sua própria forma como forma danificada vem à tona precisamente a partir do final de 1916.

No primeiro capítulo deste trabalho, aliás, chamamos a atenção para dois pequenos e significativos fragmentos escritos em março de 1917 imediatamente após as "narrativas chinesas" de Kafka (Durante a construção da Muralha da China e "Uma antiga página [da China]") e nos quais um "narrador-editor" faz referência a "páginas demasiadamente danificadas":

Diese (vielleicht allzusehr europäisierende) Übersetzung einiger alter chinesischer Manuscriptblätter stellt uns ein Freund der Aktion zur Verfügung. Es ist oin Bruchstück. Hoffnung, daß die Fortsetzung gefunden werden könnte besteht nicht.

Hier folgen noch einige Seiten, die aber allzu beschädigt sind, als daß innen etwas bestimmtes entnommen werden könnte. ${ }^{325}$

Esta tradução (talvez demasiadamente europeizada) de algumas velhas folhas manuscritas chinesas foi colocada à nossa disposição por um amigo da ação. É um fragmento. Esperança de que a continuação possa ser encontrada não existe.<smiles>[Mg][Mg]</smiles>

Aqui seguem-se ainda algumas páginas, que porém estão demasiadamente danificadas, de modo que nada definido poderia ser extraído delas.

Também destacamos como o primeiro destes fragmentos, com sua referência às "folhas manuscritas chinesas", mostra-se intimamente ligado às duas narrativas anteriores (inclusive pela manutenção do mesmo ponto de vista narrativo: um eu-narrador que também faz uso de um "nós"); ao passo que o segundo, pela quebra da perspectiva

${ }^{324}$ F. Kafka, Briefe 1902-1924 [carta a Max Brod datada de 26.06.1922], p. 375.

${ }^{325}$ F. Kafka, "Oktavheft C", em KKA N1, p. 361, grifos meus. Cf. também F. Kafka, "Oktavheft 3", em HKKA O3/4, p. 126-127. 
narrativa, exibe uma autonomia que permite que também seja lido, em vista da especificidade dos cadernos in-oitavo, como uma anotação solta do próprio escritor. ${ }^{326}$

De todo modo, é assombroso perceber como a partir de 1916, as costumeiras lamentações deste escritor sobre o caráter fragmentário de sua produção desaparecem, como que repentinamente, dando lugar a comentários nitidamente mais distanciados e sóbrios na avaliação de seus "rabiscos". Queixas como aquela que havia marcado o abandono de $O$ desaparecido:

Mein Roman! ich erklärte mich vorgestern abend vollständig von ihm besiegt. Er läuft mir auseinander, ich kann ihn nicht mehr umfassen [...]. ${ }^{327}$

Meu romance! Eu declaro-me desde anteontem à noite completamente derrotado por ele. Ele se dispersa para mim, eu não consigo mais abrangê-lo [...].

ou quando o trabalho em $O$ processo enfrentava resistências e passava a se arrastar:

Ich kann nicht mehr weiterschreiben. Ich bin an der endgiltigen Grenze, vor der ich vielleicht wieder Jahre lang sitzen soll, um dann vielleicht wieder eine neue, wieder unfertig bleibende Geschichte anzufangen. Diese Bestimmung verfolgt mich. ${ }^{328}$

Eu não consigo mais continuar escrevendo. Eu estou na fronteira definitiva, diante da qual talvez eu deva de novo permanecer durante anos, a fim de então começar talvez de novo uma nova história que ficará de novo inacabada. Esta determinação persegue-me.

já não se fazem mais ouvir ${ }^{329}$. Os novos comentários do escritor tornam-se sensivelmente mais lúcidos na avaliação de seus "fracassos". A distância que separa um comentário

${ }^{326}$ Que a figura de um "narrador-editor" (e que precisa se haver não com livros acabados, mas sim com folhas e páginas "demasiadamente danificadas") venha à tona na produção de Kafka precisamente em um contexto de reorganização radical de seus esforços produtivos já seria algo por si só sintomático. Repare, contudo, como este "narrador-editor", por sua vez, também emerge no contexto convulsivo e apodrecido exposto tanto em Durante a construção da Muralha da China quanto em "Uma antiga folha [da China]"!

${ }^{327}$ F. Kafka, Briefe an Felice [carta datada de 26.01.1913], p. 271, grifo meu.

${ }^{328}$ F. Kafka, "Zehntes Heft" [30.11.1914], em KKA T, p. 702, grifo meu.

329 À margem, sublinhe-se ainda que estas lamentações já estavam presentes desde os seus primeiros escritos:

Es kommen daher immer nur abreißende Anfänge zu Tage [...]. Würde ich einmal ein größeres Ganzes schreiben können wohlgebildet vom Anfang bis zum Ende, dann könnte sich auch die Geschichte niemals endgiltig von mir loslösen und ich dürtte ruhig und mit offenen Augen als Blutsverwandter einer gesunden Geschichte ihrer Vorlesung zuhören, so aber lauft jedes Stückchen der Geschichte heimatlos herum und treibt mich in die entgegengesetzte Richtung. (F. Kafka, "Drittes Heft" [05.11.1911], em KKA T, p. 227, grifo meu)

Por isso aparecem sempre apenas inícios que se interrompem/rasgam [abreißende Anfänge] [...]. Pudesse eu, alguma vez, escrever um grande todo, bem formado do início ao fim, então a história nunca poderia se desligar definitivamente de mim e eu poderia ouvir sua leitura tranqüila e atentamente, como parente consangüíneo de uma história saudável; desse modo porém cada pequeno pedaço da história erra sem rumo e sem casa por todos os lados e me impele na direção contrária.

Einige alte Papiere durchgelesen. Es gehört alle Kraft dazu das auszuhalten. Das Unglück, das man ertragen muß, wenn man in einer Arbeit, die immer nur in ganzem Zug gelingen kann, sich unterbricht und das ist mir bisher immer geschehn [...]. (F. Kafka, "Fünftes Heft” [08.03.1912], em KKA T, p. 398, grifos meus.)

Alguns velhos papéis lidos. [...]. A infelicidade, que se tem de suportar, quando se se interrompe em um trabalho, que apenas pode ser levado a cabo sem intervalos, e isto até agora sempre tem acontecido comigo [...]. 
sóbrio, e em si mesmo fragmentário (afinal ele mesmo não chega sequer a uma pontuação final!), como "was ich berühre, zerfällt"/“O que eu toco, desmorona-se"330 daquelas suas antigas lamentações não é pequena e deixa entrever um modo novo de conceber a própria escrita.

Do quão consciente o escritor estava das inflexões que se operavam em sua produção e de como estas, por sua vez, se faziam na esteira de um "outro homem", de um outro modo de encarar o mundo, moldado então pelos brutais e sangrentos acontecimentos que sacudiam toda a Europa (refiro-me evidentemente à Primeira Guerra Mundial, a "catástrofe primeva" do século XX), dá conta uma outra anotação deste escritor datada de 19.02.1917 - portanto, três meses após o início deste assombroso ciclo produtivo - em seu segundo caderno in-oitavo:

Alle Aussichten, zwar nebelhaft wie immer, aber veränderte Nebelbilder. In den schweren
Stiefeln, die ich heute zum erstenmal angezogen habe (sie waren ursprünglich für den
Militärdienst bestimmt) steck ein anderer Mensch.
Todas as perspectivas, como sempre nebulosas, porém imagens nebulosas modificadas.
Nas pesadas botas que eu hoje calço pela primeira vez (elas eram originalmente
destinadas ao serviço militar) entra um outro homem.

A assunção radical de um mundo em decomposição, levando-o mais fundo para dentro da própria forma - a qual também passava, a seu turno, a se desmoronar, a se decompor! $!^{332}$-, permitiu ainda a Kafka outra façanha, a saber, a de também internalizar nos meandros desta nova forma a "loucura" deste mundo "fora dos eixos", convulsionado. Afinal, como dar conta deste mundo em decomposição senão assumindo a própria decomposição como lógica interna da configuração literária, ou seja, como princípio formal? Ou em outros termos, como expor a "loucura" deste mundo em decomposição senão assumindo também visceralmente um ponto de vista compatível? Para estar à altura deste mundo que havia feito da guerra, "por exemplo", o "normal" - lembre-se aqui do lúcido comentário do escritor à irmã Ottla: "[...] das Abnormale sei nicht das schlechteste, denn normal sei z.B. der Weltkrieg"/“[...] o anormal não é o pior, se o normal é, por exemplo, a guerra mundial”333 -, Kafka conscientemente passa a explorar e a internalizar o "anormal", o monstruoso, o deformado. Exatamente neste momento se dá, ressalte-se, a "invasão" em sua forma daquelas levas de mortos-vivos e seres híbridos

\footnotetext{
${ }^{330}$ F. Kafka, "Oktavheft E”, em KKA N1, p. 407 (como já indicado, a própria anotação suspende-se, não chegando sequer a uma pontuação final).

${ }^{331}$ F. Kafka, "Oktavheft B", em KKA N1, p. 332.

${ }^{332}$ Repare para tanto como com o novo ciclo criativo que se inicia no final de 1916 a produção de Kafka tornase sintomaticamente mais quebradiça e fragmentária do que nunca.

${ }^{333}$ F. Kafka, Briefe an Ottla und die Familie [carta a Ottla Kafka datada de 30.12.1917], p. 49.
} 
bem como daquelas deformações temporais e espaciais mais extremadas. Mais do que nunca, portanto, com a produção que se inicia no final de 1916, Kafka passa a fazer da "loucura" método; e assim procedendo logrou iluminar de modo sóbrio e esclarecido não apenas a decomposição de sua Monarquia do Danúbio, mas de toda uma Europa que descia festivamente aos infernos. Às soluções formais encontradas então por este escritor para dar conta deste "sadio" mundo à sua volta poderíamos aplicar com felicidade a observação do camareiro Polônio sobre a "loucura" do príncipe Hamlet:

How pregnant sometimes his replies are - a happiness that often madness hits on, which reason and sanity could not so prosperously be delivered of. ${ }^{334}$

Wie treffend manchmal seine Antworten sind! Dies ist ein Glück, daß die Tollheit oft hat, womit es der Vernunft und dem gesunden Sinne nicht so gut gelingen könnte. ${ }^{335}$

Como suas respostas são perspicazes. É uma felicidade que a loucura alcança às vezes, e que a razão e a sanidade não tem a sorte de encontrar. ${ }^{336}$

\footnotetext{
${ }^{334}$ W. Shakespeare, Hamlet, p. 248 [Act 2, Scene 2].

${ }^{335}$ W. Shakespeare, Hamlet, trad. de A. W. Schlegel, p. 49.

${ }^{336}$ W. Shakespeare, Hamlet, trad. de A. A. C. Mendonça, p. 72.
} 


\section{REFERÊNCIAS BIBLIOGRÁFICAS}

\section{Bibliografia de Franz Kafka}

KAFKA, Franz. Kritische Kafka Ausgabe: Schriften/Tagebücher/Briefe. Org. por Jürgen Born, Gerhard Neumann, Malcolm Pasley e Jost Schillemeit. Frankfurt am Main: Fischer, 1982ff:

— Das Schloß. Org, por Malcom Pasley. 1982.

- Der Verschollene. Org. por Jost Schillemeit. 1983.

- Der Proceß. Org. por Malcom Pasley. 1990.

— Tagebücher. Org. por Hans-Gerd Koch, Michael Müller e Malcom Pasley. 1990.

— Nachgelassene Schriften und Fragmente I. Org. por Malcom Pasley. 1993.

- Nachgelassene Schriften und Fragmente II. Org. por Jost Schillemeit. 1992.

— Drucke zu Lebzeiten. Org. por Wolf Kittler, Hans-Gerd Koch e Gerhard Neumann. 1994.

— Amtliche Schriften. Org. por Klaus Hermsdorf e Benno Wagner. 2004

KAFKA, Franz. Historisch-Kritische Kafka Ausgabe sämtlicher Handschriften, Drucke und Typoskripte. Org. por Roland Reuß und Peter Staengle. Frankfurt am Main: Stroemfeld, 1997ff:

- Oxforder Oktavhefte 1 \& 2. Org. por Roland Reuß. 2006.

- Oxforder Oktavhefte 3 \& 4. Org. por Roland Reuß und Peter Staengle. 2008.

— Oxforder Oktavhefte 5 \& 6. Org por Roland Reuß und Peter Staengle. 2009.

- Oxforder Oktavhefte 7 \& 8. Org por Roland Reuß und Peter Staengle. 2010.

KAFKA, Franz. Gesammelte Werke in zwölf Bänden. Org. por Hans-Gerd Koch. 12 vols. Frankfurt am Main: Fischer, 2008.

. Ein Landarzt. (Fac-símile da 1ª Edição. Leipzig: Kurt Wolff Verlag, 1920). Frankfurt am Main: Stroemfeld, 2006.

Frankfurt am Main: Fischer, 2001.

. In der Strafkolonie: eine Geschichte aus dem Jahre 1914. Org. por Klaus Wagenbach. Berlim: Klaus Wagenbach, 2004. 
- Briefe 1902-1924. Org. por Max Brod. Nova York: Schocken, 1966.

- Briefe an Felice und andere Korrespondenz aus der Verlobungszeit. Org. por Jürgen Born e Erich Heller. Frankfurt am Main: Fischer, 2003.

. Briefe an Milena. Org. por Jürgen Born e Michael Müller. Frankfurt am Main: Fischer, 2004.

- Briefe an Ottla und die Familie. Org. por Hartmut Binder e Klaus Wagenbach. Frankfurt am Main: Fischer, 2011.

- Briefe an die Eltern aus den Jahren 1922-1924. Org. por Josef Čermák e Martin Svatoš. Frankfurt am Main: Fischer, 1990.

_. Franz Kafka: Der Dichter über sein Werk. Org. por Joachim Beug e Erich Heller. Munique: Deutscher Taschenbuch Verlag, 1977.

- Contemplação/O foguista: um fragmento. Trad. e posfácio de Modesto Carone. São Paulo: Companhia das Letras, 1999.

. O veredicto/Na colônia penal. Trad. e posfácio de Modesto Carone. São Paulo: Companhia das Letras, 1998.

. Um médico rural: pequenas narrativas. Trad. e posfácio de Modesto Carone. São Paulo: Companhia das Letras, 1999.

- Um artista da fome/A construção. Trad. e posfácio de Modesto Carone. São Paulo: Companhia das Letras, 1999.

- Narrativas do espólio. Trad. e posfácio de Modesto Carone. São Paulo: Companhia das Letras, 2002.

Lages. São Paulo: Editora 34, 2003.

"O cavaleiro do balde". Trad. de Modesto Carone. In: CARONE, Modesto. Lição de Kafka. São Paulo: Companhia das Letras, 2009, p. 7-10.

\section{Bibliografia sobre Franz Kafka}

ADORNO, Theodor Wiesengrund. "Anotações sobre Kafka". In: Prismas: crítica cultural e sociedade. Trad. de Augustin Wernet e Jorge de Almeida. São Paulo: Ática, 2001, p. 239-270.

ALLEMANN, Beda. Zeit und Geschichte im Werk Kafkas. Org. por Diethelm Kaiser e Nikolaus Lohse. Göttingen: Wallstein, 1998. 
ALT, Peter-André. Franz Kafka. Der ewige Sohn. Eine Biographie. Munique: Beck, 2005.

ANDERS, Günter. Kafka: pró e contra: os autos do processo. Trad. e introdução de Modesto Carone. São Paulo: Perspectiva, 1969.

ANDERSON, Mark. Kafka's clothes: ornament and aestheticism in the Habsburg fin de siècle. Nova York: Oxford University Press, 2002.

ANDERSON, Mark (org.). Reading Kafka: Prague, politics and fin de siècle. Nova York: Schocken Books, 1989.

ANZ, Thomas. "Kafka, der Krieg und das größte Theater der Welt". Neue Rundschau, Frankfurt am Main, 1996, Heft 3, p. 131-143.

"Kafka, der Krieg und das größte Theater der Welt". In: SCHNEIDER, Uwe;

SCHUMANN, Andreas (orgs.). "Krieg der Geister": Erster Weltkrieg und literarische

Moderne. Würzburg: Königshausen \& Neumann, 2000, p. 247-262.

_. Franz Kafka: Leben und Werk. Munique: Beck, 2009.

AUEROCHS, Bernd; ENGEL, Manfred (orgs.). Kafka Handbuch: Leben - Werk - Wirkung. Stuttgart/Weimar: Metzler, 2010.

BEIBNER, Friedrich. Der Erzähler Franz Kafka. Frankfurt am Main: Suhrkamp, 1983.

BENJAMIN, Walter. Benjamin über Kafka: Texte, Briefzeugnisse, Aufzeichnungen. Org. por Hermann Schweppenhäuser. Frankfurt am Main: Suhrkamp, 1992.

"Franz Kafka: a propósito do décimo aniversário de sua morte". In: Magia e técnica, arte e política: ensaios sobre literatura e história da cultura. Trad. de Sérgio Paulo Rouanet. São Paulo: Brasiliense, 1996, p. 137-164.

BINDER, Hartmut (org.). Kafka-Handbuch. 2 vols. Stuttgart: Alfred Kröner, 1979.

BORN, Jürgen. "Daß zwei in mir kämpfen..." und andere Aufsätze zu Franz Kafka. Fürth im Wald/Praga: Vitalis, 2001.

CANDIDO, Antonio. "Quatro esperas". Novos Estudos CEBRAP, São Paulo, no 26, 1990, p. 49-76.

CANETTI, Elias. O outro processo: as cartas de Kafka a Felice. Trad. de Herbert Caro. Rio de Janeiro: Espaço e Tempo, 1988.

CAPUTO-MAYR, Maria Luise; HERZ, Julius Michael. Franz Kafka: internationale Bibliographie der Primär- und Sekundärliteratur. 3 vols. Munique: K. G. Saur, 2000. CARONE, Modesto. Lição de Kafka. São Paulo: Companhia das Letras, 2009. 
DAVID, Claude (org.). Franz Kafka: Themen und Probleme. Göttingen: Vandenhoeck und Ruprecht, 1980.

DELEUZE, Gilles; GUATTARI, Félix. Kafka: pour une littérature mineure. Paris: Les Éditions de Minuit, 2005.

EMRICH, Wilhelm. Franz Kafka. Frankfurt am Main: Athenäum, 1961.

FARIA, Renato Oliveira de. Labirinto rabiscado: uma leitura de A construção de Franz Kafka. São Paulo: FFLCH/USP, 2005. Dissertação de mestrado, mimeo.

FRANK, Manfred. “Der Jäger Gracchus': Variationen einer modernen Phantasie”. In: Die unendliche Fahrt: ein Motiv und sein Text. Frankfurt am Main: Suhrkamp, 1979, p. 17-37.

GLIŠOVIĆ, Dušan. Politik im Werk Kafkas. Tübingen/Basel: Francke, 1996.

GOEBEL, Rolf. Constructing China: Kafka's Orientalist Discourse. Columbia: Camden House, 1997.

GRAY, Richard T. et al. A Franz Kafka Encyclopedia. Westport: Greenwood Press, 2005.

HERMES, Roger et al. Franz Kafka: eine Chronik. Berlim: Klaus Wagenbach, 1999.

JAHRAUS, Oliver. Franz Kafka: Leben, Schreiben, Machtapparate. Stuttgart: Reclam, 2006.

JAHRAUS, Oliver; JAGOW, Bettina (orgs.), Kafka Handbuch: Leben - Werk - Wirkung. Göttingen: Vandenhoeck \& Ruprecht, 2008.

KITTLER, Wolf. "Grabenkrieg - Nervenkrieg - Medienkrieg: Franz Kafka und der 1. Weltkrieg". In: HÖRISCH, Jochen; WETZEL, Michael (orgs.). Armaturen der Sinne: literarische und technische Medien 1870 bis 1920. Munique: Wilhelm Fink, 1990, p. 289-309.

$\mathrm{KOCH}$, Hans (org.). "Als Kafka mir entgegenkam...”: Erinnerungen an Franz Kafka. Berlim: Klaus Wagenbach, 2005.

$\mathrm{KOCH}$, Hans-Gerd; WAGENBACH, Klaus (orgs.). Kafkas Fabriken. Marbacher Magazin, Marbach, nำ 100, 2002.

KURZ, Gerhard. Traum-Schrecken: Kafkas literarische Existenzanalyse. Stuttgart: Metzler, 1980.

KURZ, Gerhard (org.). Der junge Kafka. Frankfurt am Main: Suhrkamp, 1984.

LEMON, Robert. "Eastern Empires and Middle Kingdoms: Austria and China in Hofmannsthal and Kafka's Orientalist Fictions". In: 
http://users.ox.ac.uk/ oaces/conference/papers/Bob Lemon.pdf

(Oxford:

Congresso The contours of legitimacy in Central Europe, 2002).

LIEBRAND, Claudia (org.). Franz Kafka: Neue Wege der Forschung. Darmstadt: Wissenschaftliche Buchgesellschaft, 2006.

LÖWY, Michael. Franz Kafka, sonhador insubmisso. Trad. de Gabriel Cohn. Rio de Janeiro: Azougue Editorial, 2005.

MENG, Weiyan. Kafka und China. Munique: ludicium Verlag, 1986.

MENNINGHAUS, Winfried. 'Der Engel des Ekels - Kafkas Poetik des 'unschuldigen' Genießens 'schwefliger' Lüste”. In: Ekel: Theorie und Geschichte einer starken Empfindung. Frankfurt am Main: Suhrkamp, 2002, p. 333-484.

MOSĖS, Stéphane. Exégèse d'une legende: lectures de Kafka. Paris: Editions de l'éclat, 2006.

MÜLLER, Michael (org.). Franz Kafka: Romane und Erzählungen. Stuttgart: Reclam, 2009.

MÜLLER-SEIDEL, Walter. Die Deportation des Menschen: Kafkas Erzählung "In der Strafkolonie" im europäischen Kontext. Frankfurt am Main: Fischer, 1989.

NEUMANN, Bernd. Franz Kafka: Gesellschaftskrieger. Munique: Wilhelm Fink, 2008.

NICOLAI, Ralf. Kafkas "Beim Bau der chinesischen Mauer" im Lichte Themenverwandter Texte. Würzburg: Könnigshausen und Neumann, 1991.

POLITZER, Heinz. Franz Kafka: Der Künstler. Frankfurt am Main: Suhrkamp, 1978.

POLITZER, Heinz (org.). Franz Kafka. Darmstadt, Wissenchaftliche Buchgesellschaft, 1980.

PREECE, Julian (org.). The Cambridge Campanion to Kafka. Cambridge: Cambridge University Press, 2002.

ROSENFELD, Anatol. "Kafka e kafkianos". In: Texto/contexto I. São Paulo: Perspectiva, 1996, p. 225-262.

_. "Kafka redescoberto". In: Letras e leituras. São Paulo: Perspectiva, 1994, p. 33-39.

"Kafka e o romance moderno". In: Letras e leituras. São Paulo: Perspectiva, 1994, p. 41-64.

SCHERPE, Klaus R.; WAGNER, Elisabeth (orgs.). Kontinent Kafka: Mosse-Lectures an der Humboldt-Universität zu Berlin. Berlim: Vorwerk 8, 2006. 
SCHILLEMEIT, Jost. Kafka-Studien. Göttingen: Wallstein, 2004.

SCHMIDT-DENGLER, Wendelin; WINKLER, Norbert (orgs.). Die Vielfalt in Kafkas Leben und Werk. Fürth im Wald/Praga: Vitalis, 2005.

SCHÜTTERLE, Annette. Franz Kafkas Oktavhefte. Freiburg im Breisgau: Rombach, 2002.

SCHWARZ, Roberto. "Uma barata é uma barata é uma barata". In: $A$ sereia e o desconfiado: ensaios críticos. Rio de Janeiro: Paz e Terra, 1981, p. 59-72.

—. "Tribulação de um pai de família". In: O pai de família e outros estudos. Rio de Janeiro: Paz e Terra, 1992, p. 21-26.

SOKEL, Walter. Franz Kafka - Tragik und Ironie: zur Struktur seiner Kunst. München/Wien: Albert Langen/Georg Müller, 1964.

STACH, Reiner. Kafka: die Jahre der Entscheidungen. Frankfurt am Main: Fischer, 2002. Kafka: die Jahre der Erkenntnis. Frankfurt am Main: Fischer, 2008.

STÖLZL, Christoph. Kafkas Böses Böhmen: zur Sozialgeschichte eines Prager Juden. Frankfurt am Main: Ullstein, 1989.

UNSELD, Joachim. Franz Kafka: ein Schriftstellerleben. Frankfurt am Main: Fischer, 1984.

VOGL, Joseph. Ort der Gewalt: Kafkas literarische Ethik. Munique: Wilhelm Fink, 1990.

WAGENBACH, Klaus. Franz Kafka: Biographie seiner Jugend (1883-1912). Berlim: Klaus Wagenbach, 2006.

. Franz Kafka: Bilder aus seinem Leben. Berlim: Klaus Wagenbach, 2008.

. Franz Kafka. Reinbeck bei Hamburg: Rowohlt, 2008.

Kafkas Prag: ein Reiselesebuch. Berlim: Verlag Klaus Wagenbach, 1993.

WALSER, Martin. Beschreibung einer Form: Versuch über Franz Kafka. Frankfurt am Main: Suhrkamp, 1999.

\section{Bibliografia geral}

ADORNO, Theodor W. Ästhetische Theorie. Org. por Gretel Adorno e Rolf Tiedemann. Frankfurt am Main: Suhrkamp, 1973.

- Philosophie der neuen Musik. Frankfurt am Main: Suhrkamp, 1990.

Minima Moralia: reflexões a partir da vida danificada. Trad. de Luiz Eduardo Bicca. São Paulo: Ática, 1993. 
- Minima Moralia: reflexões a partir da vida lesada. Trad. de Gabriel Cohn. São Paulo, 2008.

- Notas de literatura I. Trad. e apresentação de Jorge de Almeida. São Paulo: Duas Cidades/Editora 34, 2003.

ADORNO, Theodor W.; HORKHEIMER, Max. Dialética do esclarecimento: fragmentos filosóficos. Trad. de Guido Antonio de Almeida. Rio de Janeiro: Jorge Zahar Editor, 1985.

ALMEIDA, Jorge de. Crítica dialética em Theodor Adorno: música e verdade nos anos vinte. São Paulo: Ateliê Editorial, 2007.

ARANTES, Paulo Eduardo. Sentimento da dialética na experiência intelectual brasileira: dialética e dualidade segundo Antonio Candido e Roberto Schwarz. São Paulo: Paz e Terra, 1992.

Ressentimento da dialética: dialética e experiência em Hegel (antigos estudos sobre o ABC da Miséria Alemã). São Paulo: Paz e Terra, 1996.

AUERBACH, Erich. Mimesis: a representação da realidade na literatura ocidental. São Paulo: Perspectiva, 2002.

BENJAMIN, Walter. Das Passagen-Werk. 2 vols. Frankfurt am Main: Suhrkamp, 1983. . Origem do drama barroco alemão. Trad. de Sérgio Paulo Rouanet. São Paulo: Brasiliense, 1984.

. Documentos de cultura/Documentos de barbárie: escritos escolhidos. Seleção e apresentação de Willi Bolle. São Paulo: Cultrix/Edusp, 1986.

BOLLE, Willi. Fisiognomia da metrópole moderna: representação da história em Walter Benjamin. São Paulo: Edusp, 2000.

BORNHEIM, Gerd. Brecht: a estética do teatro. Rio de Janeiro: Graal, 1992.

CANDIDO, Antonio. Literatura e sociedade. São Paulo: T. A. Queiroz/Publifolha, 2000.

CANDIDO, Antonio et al. A personagem de ficção. São Paulo: Perspectiva, 2002.

CORNWALL, Mark (org.). Die letzten Jahre der Donaumonarchie: der erste Vielkvölkerstaat im Europa des frühen 20. Jahrhunderts. Magnus Verlag, 2006.

DECLOEDT, Leopold (org.). An meine Völker: die Literarisierung Franz Josephs I. Berna: Peter Lang, 1998.

DUARTE, Rodrigo. Adornos: nove ensaios sobre o filósofo frankfurtiano. Belo Horizonte: Editora UFMG, 1997. 
EBREY, Patricia Buckley. The Cambridge Illustrated History of China. Cambridge: Cambridge University Press, 1996.

ENZENSBERGER, Hans Magnus. Guerra civil. Trad. de Marcos Branda Lacerda e Sergio Flaksman. São Paulo: Companhia das Letras, 1995.

FETSCHER, Justus. "Fragment”. In: BARCK, Karheinz (org.). Ästhetische Grundbegriffe: ein historisches Wörterbuch. Vol. 2. Stuttgart/Weimar: Metzler, 2001, p. 551-588.

GAGNEBIN, Jeanne Marie. História e narração em Walter Benjamin. São Paulo: Perspectiva, 1999.

. "Entre a vida e a morte". In: CORNELSEN, Elcio et al (orgs.). Limiares e passagens em Walter Benjamin. Belo Horizonte: Editora UFMG, 2010, p. 12-26.

GEHLER, Michael; STEININGER, Rolf. Österreich im 20.Jahrhundert: von der Monarchie bis zum Zweiten Weltkrieg. Viena/Colônia/Weimar: Böhlau, 1997.

HANISCH, Ernst; WEISS, Walter (orgs.). Vermittlungen: Texte und Kontexte österreichischer Literatur und Geschichte im 20.Jahrhundert. Viena/Salzburgo: Residenz Verlag, 1990.

HARTH, Dietrich. "China - Monde imaginaire der europäischen Literatur". In: HARTH, Dietrich (org.). Fiktion des Fremden: Erkundung kultureller Grenzen in Literatur und Publizistik. Frankfurt am Main: Fischer, 1994, p. 203-223.

HIRSCHFELD, Gerhard et al. (orgs.), Enzyklopädie Erster Weltkrieg. Paderborn: Ferdinand Schöningh, 2009.

HÖBELT, Lothar. Franz Joseph I: Der Kaiser und sein Reich: Eine politische Geschichte. Viena: Böhlau, 2009.

HOBSBAWM, Eric. A era do capital: 1848-1875. Trad. de Luciano Costa Neto. Rio de Janeiro: Paz e Terra, 2005.

A era dos impérios: 1875-1914. Trad. de Sieni Maria Campos e Yolanda Steidel de Toledo. Rio de Janeiro: Paz e Terra, 2003.

Nações e nacionalismo desde 1780. Trad. de Maria Celia Paoli e Anna Maria Quirino. Rio de Janeiro: Paz e Terra, 2004.

INGRAO, Charles. The Habsburg Monarchy 1618-1815. Cambridge: Cambridge University Press, 2000.

KANN, Robert A. Geschichte des Habsburgerreiches: 1526 bis 1918. Trad. de Dorothea Winkler. Viena/Colônia/Weimar: Böhlau, 1993. 
KOTT, Jan. Shakespeare nosso contemporâneo. Trad. de Paulo Neves. São Paulo: Cosac \& Naify, 2003.

KRAUS, Karl. Die letzten Tage der Menschheit. Frankfurt am Main: Suhrkamp, 2005.

KURZ, Robert. O colapso da modernização: da derrocada do socialismo de caserna à crise da economia mundial. Trad. de Karen Alsabe Barbosa. Rio de Janeiro: Paz e Terra, 1999.

LUKÁCS, Georg. A teoria do romance: um ensaio histórico-filosófico sobre as formas da grande épica. Trad. de José Marcos Mariani de Macedo. São Paulo: Duas Cidades/Editora 34, 2000.

MAGRIS, Claudio. Der habsburgische Mythos in der österreischischen Literatur. Salzburgo: Otto Müller, 1988.

MEHL, Dieter. Shakespeares Hamlet. Munique: Beck, 2007.

MOMMSEN. Wolfgang. Die Urkatastrophe Deutschlands: Der Erste Weltkrieg 1914-1918. Stuttgart: Klett-Cotta, 2004.

ÖHLER, Dolf. O velho mundo desce aos infernos: auto-análise da modernidade após o trauma de junho de 1848 em Paris. Trad. de José Marcos Macedo. São Paulo: Companhia das Letras, 2000.

Terrenos vulcânicos. Trad. de Samuel Titan Jr. et al. São Paulo: Cosac \& Naify, 2004.

PASTA JÚNIOR, José Antonio. Trabalho de Brecht: breve introdução ao estudo de uma classicidade contemporânea. São Paulo: Ática, 1986.

"O romance de Rosa: temas do Grande Sertão e do Brasil". Novos Estudos CEBRAP, São Paulo, no 55, 1999, p. 61-70.

. "Le point de vue de la mort: une structure récurrente de la culture brésilienne". In: PENJON, Jacqueline (org.). Voies du paysage. Paris: Presses Sorbonne Nouvelle, 2007, p. 157-168.

PEYREFITTE, Alain. O império imóvel ou o choque dos mundos. Trad. de Cylene Bittencourt. Niterói: Casa Jorge Editorial, 1997.

RAUCHENSTEINER, Manfried. Der Tod des Doppeladlers: Österreich-Ungarn und der Erste Weltkrieg. Graz/Viena/Colônia: Styria, 1997.

RINESI, Eduardo. Política e tragédia: Hamlet, entre Hobbes e Maquiavel. Rio de Janeiro: Azougue Editorial, 2009.

ROSENFELD, Anatol. O teatro épico. São Paulo: Perspectiva, 2000. 
SHAKESPEARE, William. Hamlet. Editado por Harold Jenkins. Londres: Routledge, 1994. Hamlet. Trad. de August Wilhelm Schlegel. Frankfurt am Main: Fischer, 2008.

Hamlet. Trad. de Heiner Müller. In: MÜLLER, Heiner. Shakespeare Factory 2. Berlim: Rotbuch Verlag, 1994.

Hamlet. Trad. de Millôr Fernandes. Porto Alegre: L\&PM, 2010.

. Hamlet e Macbeth. Trad. de Anna Amélia Carneiro de Mendonça (Hamlet) e Barbara Heliodora (Machbeth). Rio de Janeiro: Nova Fronteira, 1995.

SCHEUCH, Manfred. Historischer Atlas Österreich. Viena: Brandstätter, 2008.

SCHMELING, Manfred. Der labyrinthische Diskurs: vom Mythos zum Erzählmodell. Frankfurt am Main: Athenäum, 1987.

SCHORSKE, Carl E. Viena fin-de-siècle: política e cultura. Trad. de Denise Bottmann. São Paulo: Companhia das Letras, 1988.

SCHWARZ, Roberto. Ao vencedor as batatas: forma literária e processo social nos inícios do romance brasileiro. São Paulo: Duas Cidades/Editora 34, 2000.

- Um mestre na periferia do capitalismo: Machado de Assis. São Paulo: Duas Cidades/Editora 34, 2000.

Que horas são? São Paulo: Companhia das Letras, 1997.

- Seqüências brasileiras. São Paulo: Companhia das Letras, 1999.

SHAPIRO, James. 1599: Um ano na vida de William Shakespeare. São Paulo: Planeta, 2010.

SPITZER, Leo. Lingüistica e Historia Literaria. Madri: Editorial Gredos, 1961.

STRINDBERG, August. Inferno. Trad. de Ismael Cardim. São Paulo: Editora 34, 2009.

SZONDI, Peter. Teoria do drama moderno (1880-1950). Trad. de Luiz Sérgio Repa. São Paulo: Cosac \& Naify, 2001.

VOCELKA, Karl. Österreichische Geschichte. Munique: Beck, 2005.

. Die Familien Habsburg und Habsburg-Lothringen: Politik - Kultur - Mentalität. Viena: Böhlau, 2010.

WEIGEL, Hans et al. (orgs). Jeder Schuss ein Russ, Jeder Stoss ein Franzos: literarische und graphische Kriegspropaganda in Deutschland und Österreich 1914-1918. Viena: Christian Brandstätter, 1983. 
WEISS, Walter. "Zur Kulturgeschichte der Zeit Franz Josephs in Österreich". In: SZABÓ, János et alii (orgs.) Kakanien: Aufsätze zur österreichischen und ungarischen Literatur, Kunst und Kultur um die Jahrhundertwende. Viena/Budapeste: Österreichischen Akademie der Wissenschaft/Akadémiai Kiadó, 1991, p. 59-83.

ŽIŽEK, Slavoj. Bem-vindo ao deserto do real!. Trad. de Paulo Cezar Castanheira. São Paulo: Boitempo Editorial, 2003. 